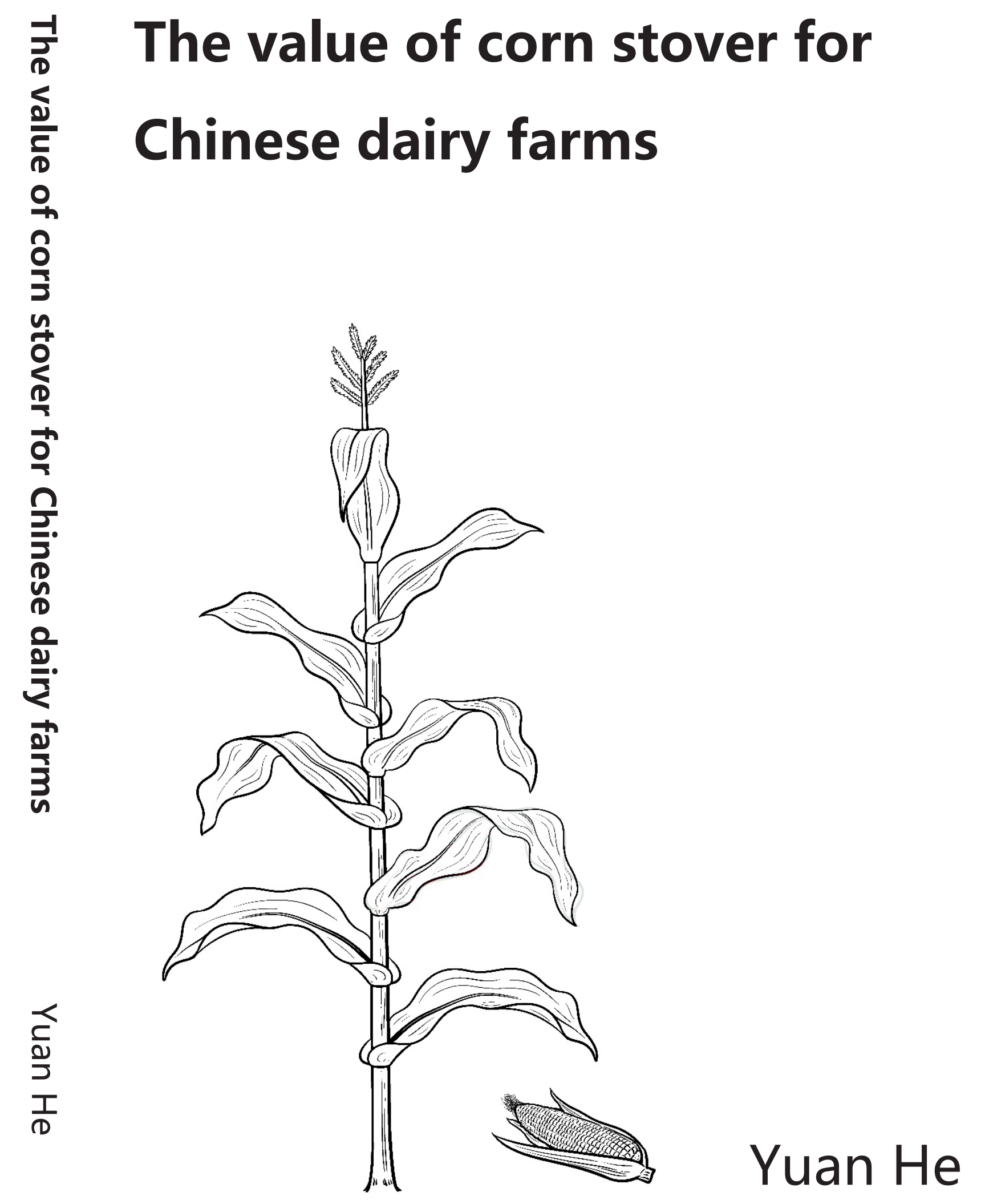


The value of corn stover for Chinese dairy farms Yuan He 


\section{Thesis committee}

\section{Promotors}

Prof. Dr W.H. Hendriks

Professor of Animal Nutrition

Wageningen University \& Research

Dr J. Dijkstra

Associate Professor, Animal Nutrition Group

Wageningen University \& Research

\section{Co-promotor}

Dr J.W. Cone

Researcher, Animal Nutrition Group

Wageningen University \& Research

\section{Other members}

Prof. Dr I.J.M. de Boer, Wageningen University \& Research

Dr J.T. Schonewille, Utrecht University, Utrecht

Dr M.A.M. Rodrigues, University of Trás-os-Montes and Alto Douro, Vila Real, Portugal

Dr J. Martín-Tereso, Trouw Nutrition BV, the Netherlands

This research was conducted under the auspices of the Graduate School of Wageningen Institute of Animal Sciences (WIAS). 


\title{
The value of corn stover for Chinese dairy farms
}

\author{
Yuan $\mathrm{He}$
}

\section{Thesis}

submitted in fulfilment of the requirements for the degree of doctor

$$
\text { at Wageningen University }
$$

by the authority of the Rector Magnificus,

$$
\text { Prof. Dr A.P.J. Mol, }
$$

in the presence of the

Thesis Committee appointed by the Academic board

to be defended in public

on Wednesday 1 May 2019

at 11 a.m. in the Aula. 
Yuan $\mathrm{He}$

The value of corn stover for Chinese dairy farms, 198 pages.

$\mathrm{PhD}$ thesis, Wageningen University, Wageningen, NL (2019)

With references, with summary in English

ISBN 978-94-6343-917-6

DOI https://doi.org/10.18174/472878 


\section{Table of Contents}

Chapter 1 General introduction 1

Chapter 2 Relationships between chemical composition and in vitro gas 25 production parameters of corn leaves and stems

Chapter 3 Lignin composition is more important than content for corn stem cell wall degradation

Chapter 4 The nutritional value of the lower corn stem cannot be improved by ensiling nor by a fungal treatment

Chapter 5 Corn stover usage and farm profit for sustainable dairy farming in

China

Chapter 6 General discussion

Summary

Ackonwledgements

About the author

Curriculum vitae

Overview of scientific publications

Training and supervision plan 
Chapter 1

General introduction 


\section{CHAPTER 1}

\subsection{Introduction}

Corn, an important economic crop, is commonly grown in China. It is estimated that approximately 0.24 billion tons of corn stover, which consists of leaves and stems, is generated annually (Zuo et al., 2015) with most of the corn grains used as food and feed. There is increasing demand to use corn grains for ethanol production, in the starch processing industry and for glucose production (Gao, 2011). In rural areas, about 70\% of the stover is burned on the field or used as household fuel, and only $10 \%$ is used as a ruminant feed (Yang and Gao, 2016) due to its low degradability resulting from its highly lignified cell walls. The more corn stover is fed to ruminant animals, the less will be burned, which contributes to improvement in air quality. In recent years in China, the price of ground corn, soybean meal, alfalfa hay, etc. has increased but the price of raw milk did not increase to the same extent (Liu and Li, 2017; Li et al., 2018). As a result, the profit of dairy farms in China decreases. Utilization of local forages such as corn stover may help dairy farmers to reduce feed costs due to the lower price of corn stover (Shi et al., 2015b) and to increase their profit since in general, feed costs are the greatest expense in dairy farms (Buza et al., 2014). Last but not the least, making the best use of corn stover can improve the efficiency with which land is used. It is expected that $70 \%$ to $100 \%$ more food is needed in 2050 compared with food demand in 2010 (Godfray et al., 2010), which leads to increasing demand of arable land. Compared with burning corn stover on the field, ruminant animals can use the stover to produce food and more food can be produced by using the resource on the same land. Due to the benefits mentioned above and the increasing number of dairy cattle in China (Liu and $\mathrm{Li}, 2017$ ), it is important to improve the utilization of corn stover (leaves and stems) to be able to improve the profitability of dairy farms in China.

\subsection{Morphological fractions of corn plants}

The major parts of a whole corn plant are leaves, stems, ear(s), husks and tassel. A corn leaf is long, narrow, undulated and tapers towards the tip and its main function is capturing light for photosynthesis. As the main body of the plant, the stem, which is also called stalk, provides the pathways to transport nutrients up and down the plant, acting as the bridge between the leaves and the roots. To support the weight of the ear and prevent wind damage, the stem should be strong. The ear, which can be more than 
one in a single plant, can be separated into grains and cob. The latter is the core of the ear and surrounded by the grains. The leafy outer covering of the ear is the husk (or hull), and acts as physical protection for the ear. Tassel is the male flower of the corn plant and responsible for producing pollen which can stimulate the growth and ripening of the ear. It appears on the top of the plant.

According to Verbic et al. (1995), the proportion of these morphological fractions in the whole plants decreases in the order grain $>$ stems $>$ leaves $>$ cobs $>$ husks (tassel was not included). The grain is the major proportion of the whole plant and ranges from $40.1 \%$ to $49.0 \%$ on a dry matter (DM) basis (Verbic et al., 1995). The stems and leaves are the main proportion among the remaining part of the plant. Verbic et al. (1995) and Tolera and Sundstol (1999) reported a greater proportion of the stems than the leaves. In contrast, a greater contribution of the leaves to the whole plant than the stems was found by Tang et al. $(2008,2009)$. The production of husks was reported to be about half of the production of the stems (Tolera and Sundstol, 1999; Tang et al., 2009) while Verbic et al. (1995) found that the husks constituted $6 \%$ of the whole plant and was about $25 \%$ of the weight of the stems which constituted $24 \%$ of the whole plant on a DM basis. However, Tolera et al. (1999) reported that there was no difference between the proportion of the stems and the husks of the investigated cultivars. The proportion of the cob is always higher than the husks (Verbic et al., 1995; Tang et al., 2008). Verbic et al. (1995) and Tang et al. (2008) found the proportion of the cob to be $42.1 \%$ and $70.8 \%$ higher than that of the husks, respectively. In contrast to the leaves, stems and ear, tassel has the lowest biomass production, and the proportion of tassel in the whole plant was reported to be less than $2 \%$ on a DM basis (Tolera et al., 1999; Tolera and Sundstol, 1999).

It is well known that the morphological fractions differ in chemical composition. Compared with the other parts of the plant, the grain has a higher starch content and a lower neutral detergent fiber (NDF) content, which results in higher degradability of the grain than the other, usually fiber-rich, fractions. The cob contains higher amounts of NDF than the leaves, stems and husks, and the acid detergent fiber (ADF) content of the cob is similar with that of the stems, which is higher than that of the leaves and husks (Verbic et al., 1995). However, Tang et al. (2008) reported that the husks have higher amounts of NDF than the leaves, stems and cob, and the stems have higher amounts of ADF than the leaves, husks and cob. The chemical composition of the 


\section{CHAPTER 1}

leaves, stems, husks and tassel were investigated by Tolera and Sundstol (1999) and they found the highest NDF and ADF content is in the husks and stems, respectively. The highest acid detergent lignin (ADL) content was found in the cob, followed by the stems (Verbic et al., 1995). The stems always contain a higher amount of ADL than the leaves (Verbic et al., 1995; Tolera and Sundstol, 1999).

In general, the grain is more degradable than the other parts of the plant due to its higher starch content. The starch content in the grain is more than $65 \%$ on a DM basis (Albornoz and Allen, 2018; Fernandes et al., 2018). It is, therefore, logical that the degradability of the grain is mainly determined by the degradability of the starch in the grain, which has been extensively investigated in the past 20 years. The starch in whole plant corn silage (WPCS) and high moisture corn can be almost completely digested when passing through the whole digestive tract of dairy cows (Khan et al., 2015b). In a meta-analysis, Moharrery et al. (2014) reported that for dairy cows, the total tract digestibility of starch in WPCS is $96.2 \%$, which is consistent with Khan et al. (2015b) who found that the total tract digestibility of starch in WPCS was more than $96.0 \%$ in dairy cows. Many factors, such as the starch composition (amylose:amylopectin), endosperm type (floury vs. vitreous) and texture (vitreousness) which are influenced by corn genotype, growing conditions, maturity stage and ensiling period (Hoffman et al., 2011; Khan et al., 2015b), affect the digestion of starch. More discussion on the starch degradability can be found in the review by Khan et al. (2015b).

The cob is the least degradable part of the plant and there is no significant difference in the effective degradability among the leaves, stems and husks when the in situ method is used to assess the degradability (Verbic et al., 1995). Similarly, by using the in situ method, Tolera and Sundstol (1999) also found that the effective degradability of the leaves, stems, husks and tassel did not differ from each other. However, in the same study, upon incubation for 72 hours in rumen fluid of sheep, the in vitro gas production (IVGP) of the husks was higher than that of the leaves, stems and tassel. Tang et al. (2008) found that the in vitro organic matter (OM) degradability of the stems was lower than that of the leaves, husks and cob after incubation in rumen fluid of goats for 72 hours. Although the DM or OM rumen degradability of different morphological fractions (leaves, stems, cobs, etc.) and the NDF degradability of the leaf fractions (sheath and blade) and stem fractions (rind, pitch and node) were investigated in previous studies, little is known about the NDF degradability of leaves and stems. Oba 
and Allen (1999) reported that the NDF degradability of forages is positively correlated with voluntary DM intake and fat corrected milk yield of dairy cows. Due to the importance of NDF degradability of forages to the production performance of dairy cows, knowledge on NDF degradability of leaves and stems may help to improve utilization of corn stover for dairy cows by separating leaves and stems. It is hypothesized that leaves have a higher degradability than stems and provide a greater amount of absorbed nutrients in dairy cattle, and therefore leaves may be fed to high producing cows (high nutritional demands), and stems to low producing or dry cows (low nutritional demands).

Due to differences in corn cultivars and harvesting date in previous studies, the proportion and chemical composition of the morphological fractions, even the ranking of these fractions, are inconsistent. It has been demonstrated that corn cultivars show variation in the proportion of different morphological fractions (Verbic et al., 1995; Tang et al., 2008). Tolera and Sundstol (1999) harvested corn plants at three maturity stages and found that the proportion of tassel and leaf blade was least while that of stem was highest in the third maturity stage (when the moisture content of the grain was around $10 \%$ ) compared with the other two maturity stages (when the moisture content of the grain was around $20 \%$ and $30 \%$ ). It is also likely that agronomic management such as plant density, irrigation, fertilizer, and temperature during the growing season can result in inconsistent results (Hu et al., 2009; Budakli Carpici et al., 2010; Islam et al., 2012; Mussadiq et al., 2013). In terms of degradability, not only the factors mentioned above, but also the different methods (in situ, in vitro OM or DM degradability, and IVGP) used to evaluate the degradability contribute to the conflicting findings (Verbic et al., 1995; Tolera and Sundstol, 1999; Tang et al., 2008).

\subsection{Lignification: barrier of cell wall degradation}

In contrast to the corn grain, which mainly consists of starch, corn stover (leaves and stems) is high in cell walls. The major components of cell walls include cellulose, hemicellulose and lignin. Cellulose is a long chain polysaccharide that is a $\beta$-D-glucan, and each polymer contains 7000 to 15000 glucose molecules (Gibson, 2012). In contrast, hemicellulose contains a shorter chain (500-3000 monomer units) and the structural types of hemicellulose can be divided into 4 forms, i.e., xylans, mannans, 


\section{CHAPTER 1}

m ixed linkage $\beta$ glucans and xyloglucans (Ebringerova et al., 2005). Lignin can be described as three-dimensional networks, built up of phenyl propane units. It is generally agreed that the precursors of these building stones are coniferyl, sinapyl, and p-coumaryl alcohols, which are transformed into guaiacyl ( $\mathrm{G}$ unit), syringyl (S unit) and $p$-hydroxyphenyl ( $\mathrm{H}$ unit) units, respectively by a complex dehydrogenative polymerization process. The ratio of these units in the different species of plants varies (Jung and Buxton, 1994; Sewalt et al., 1997; Guo et al., 2001; Van Kuijk et al., 2016). These phenyl propane units are interconnected by a series of ether and carbon-carbon linkages, in various bonding patterns (Adler, 1977; Tanahashi and Higuchi, 1989). This contributes to the process of lignification in the cell wall (MacAdam and Grabber, 2002). It has been frequently emphasized that not only the lignin content, but also the variation in composition of the various components and bonds influences the forage degradability and nutritional value (Raffrenato et al., 2017). Lignin can also be classified into core and noncore lignin, on the basis of their relative susceptibility towards hydrolysis. Noncore lignin which was first defined as ester-linked $p$-coumaric and ferulic acids (Gordon, 1975) consists of low-molecular weight phenolics and is released from cell walls by mild hydrolysis (Hartley and Ford, 1989). The term core lignin first appeared in papers by Hartley (1972) and Gordon and Neudoerffer (1973) on forage lignin but without a substantive definition or criterion. Compared with noncore lignin, core lignin can be defined as highly condensed phenyl propane cell wall polymers that are largely resistant to mild degradation procedures. These two types are important because according to Jung (1989), the nutritional value is not only influenced by the amount of lignin, but also by the nature of the lignin.

Lignification starts and ends in the order of cell corner region, primary wall, compound middle lamella and secondary wall. Only when the secondary cell wall thickens, the primary cell wall starts lignification and only after that, the secondary cell wall begins lignification. The final concentration of lignin in the middle lamella and primary cell wall is higher than that in the secondary cell wall, but because the secondary cell wall is much thicker, the total amount of lignin is at its greatest in the secondary cell wall (Terashima et al., 1993). During the deposition of lignin in the cell walls, water is removed, and that makes the cell wall hydrophobic (Inomana et al., 1992). The extent to which lignin is present in plant tissues is genetically determined, but it can also be influenced by maturity stage and environmental factors such as temperature. Lignin is 
a key component in the plant because it protects the plant against pathogens and weather conditions (such as wind) and combines the structural strength and stiffness (Boon et al., 2005). Three kinds of monolignol units are incorporated at different stages of cell wall formation in the order: H, G, and S units (Terashima and Fukushima, 1988, 1989). Because lignification occurs in the cell corner and middle lamella at an early stage and in the secondary wall at a late stage, the monolignols deposit to different extents in different morphological regions of the developing cell wall. The $\mathrm{H}$ unit is incorporated only in the earliest stage mainly into the cell corner and middle lamella lignin, and is not found in the secondary wall lignin. Deposition of the $\mathrm{G}$ unit continues throughout early to late stages in cell walls. Large amounts of S unit are deposited mainly in the middle and late stages. Therefore, the S unit is deposited mostly in the secondary wall of fiber (Terashima et al, 1993). Studies on forages of different maturities indicate a shift in the S/G unit ratio towards a more S-type lignin with advancing maturity in some species (Buxton and Russell, 1988). Physiological maturation also results in higher lignin concentrations as the secondary wall is lignified and thickening proceeds. These observations suggest that deposition of a S-type lignin will be less detrimental to total cell wall polysaccharide degradability than the G-type lignin deposited earlier in the middle lamella and primary wall. A G unit rich lignin will be more inhibitory to cell wall polysaccharide hydrolysis by rumen microbes because the lignin polymer is more branched and condensed in this proposed system, resulting in higher lignin/polysaccharide ratios in the primary wall and middle lamella than seen in the secondary wall where S unit rich lignin occurs, which may be more linear in structure (Jung and Deetz, 1993). Therefore, the secondary wall has a greater available area in which hydrolytic enzymes can attack polysaccharides between lignin chains than in the more highly branched lignin structure of the primary wall.

Theoretically, non-lignified tissues are highly degradable. As a tissue becomes more lignified, the degradability decreases. Although secondary cell walls are highly degradable, the primary cell wall will act as a perfect barrier for bacteria, unless mechanically disrupted (Engels, 1989). Any tissue with lignified cell walls will not be fully degraded, even after prolonged incubation in the rumen (Engels, 1989). This nondegradable residue which is left is the intense lignified primary cell wall, which forms an impermeable barrier to rumen bacteria. However, rumen bacteria can digest cell walls from the lumen side of cells, attacking the lumen side of the secondary wall first 


\section{CHAPTER 1}

and progressively digesting the wall towards the primary wall. Digestion halts when the structure of the remaining lignified wall becomes completely non-degradable (Chesson, 1993). Because bacteria cannot break down the highly lignified primary cell wall, they cannot simply go from one secondary cell wall to the adjacent cell wall, which is possible in non-lignified tissues (Engels and Jung, 2005).

Lignin content of forages has been observed to be negatively related with cell wall degradability (Johnson et al., 1962) and this negative relationship between lignin content and cell wall degradability was also reported in both grass (Jung et al., 1997; Casler and Jung, 2006) and legumes (Jung et al., 1997; Jung and Lamb, 2003). However, Cone and Engels (1993) reported that there was no difference in cell wall degradability between maize cultivars even when the lignin content differed. This is an unexpected finding, because during plant maturation, the cell wall degradability decreases (Boon et al., 2008) and both lignin content and composition change (Grabber, 2005). Knowledge on which factors (ADL content or composition) are more decisive for cell wall degradability of corn stem is insufficient.

\subsection{Pretreatment to improve the degradation of corn stover}

Due to the high cell wall content, inclusion of corn stover in the ration of dairy cows can provide sufficient physical effective fiber to stimulate chewing and saliva secretion and help to avoid ruminal acidosis (Zebeli et al., 2012). However, the shortage of readily fermentable carbohydrates in corn stover is detrimental for the synthesis of microbial crude protein in the rumen when the nitrogen $(\mathrm{N})$ is provided by other feedstuffs in the ration and the uncoupled supply of energy and $\mathrm{N}$ can decrease $\mathrm{N}$ efficiency, which results in more $\mathrm{N}$ excretion causing environmental pollution (Lascano and Heinrichs, 2011; Zhu et al., 2013; Wang et al., 2014). It is necessary to improve the fiber degradation in corn stover for dairy cows, not only with a view to improve $\mathrm{N}$ efficiency, but also because the increase in fiber degradation can contribute more volatile fatty acids, which can be metabolized in the liver of cows and supply energy, to the cows (Reynolds et al., 1988).

There are large amounts of potentially degradable carbohydrates in the cell walls. The lignin present in the corn stover is tightly linked with hemicellulose and cellulose via covalent, ester, or ether linkages (Susmel and Stefanon, 1993; Jeffries, 1994; Jalc, 2002; 
Vanholme et al., 2010; Ding et al., 2012), which hampers full degradation of the potentially degradable carbohydrates in the rumen of dairy cows (Wilson and Mertens, 1995). Lignin content, therefore, is negatively related with the cell wall degradation of forages in the rumen (Boon et al., 2005; Arora and Sharma, 2009; Tuyen et al., 2012; Van Kuijk et al., 2015, 2016). Removing lignin is a prerequisite to increase the accessibility of carbohydrates for rumen microorganisms. Generally, the methods to remove lignin include physical, chemical, and biological treatments.

\subsubsection{Physical treatment}

Many physical methods have been used in the industry for ethanol production and have been proven to be effective to lower the cellulose crystallinity in corn stover (Hendriks and Zeeman, 2009; Agbor et al., 2011; Sarkar et al., 2012; Chatuvedi and Verma, 2013). However, most of these methods are not feasible at dairy farms due to the high operational costs of these methods. So far, the most-commonly used physical method in dairy farms to pre-treat corn stover before being fed to dairy cattle is chopping to reduce its particle size. Moderate decrease in particle size is believed to promote fiber degradation in the rumen due to an increase of the available surface area for attachment of rumen microorganism (Olschlager, 2007; Weber, 2007; Zebeli et al., 2008). However, Keys and Smith (1983) reported that grinding was not beneficial for corn stover degradability, but the reason may be that the corn stover was ground through a $6.35 \mathrm{~cm}$ screen which can still be considered to be a relatively large particle size.

\subsubsection{Chemical treatment}

Chemical treatment involves the application of acid and alkali; the alkali treatment is more popular than the acid treatment on farms. According to Shi et al. (2012), the cost of acid is higher than alkali treatment and the fiber degradability is not significantly improved by acid treatment. Castro et al. (1993) found that adding sulfuric acid (12 and $18 \mathrm{~g} / \mathrm{kg}$ wheat straw on a DM basis) followed by a high temperature $\left(134^{\circ} \mathrm{C}\right)$ steam treatment can increase the IVGP of wheat straw, but not in steam of $98^{\circ} \mathrm{C}$. It is possible that at room temperature, sulfuric acid has no beneficial effect on the degradability of wheat straw due to the solubilization of hemicellulose by sulfuric acid (Castro et al., 


\section{CHAPTER 1}

1993). Therefore, the acid treatment is seldom used to pretreat corn stover at on dairy farms. Alkaline pretreatment can break down the linkages between lignin and the other carbohydrates in lignocellulosic biomass, making the carbohydrates more accessible to the rumen microorganism (Jackson, 1977). However, these methods are not selective and will cause losses of cellulose and hemicellulose during the treatment. The potentially negative influence on the environment should also be considered (Jackson, 1977).

Sodium hydroxide $(\mathrm{NaOH})$ treatment: Beneficial results on degradability and animal performance from using $\mathrm{NaOH}$ to treat crop residues have been documented (Jackson, 1977; Homb, 1984), even though animal performance is not always improved greatly (Rexen and Knudsen, 1984; Wilkinson, 1984). When treated with 5\% NaOH, NDF concentration is reduced by $14 \%$ and more specifically, $35 \%$ of hemicellulose, $8.7 \%$ of cellulose and $11.3 \%$ of lignin is solubilized, leading to a higher DM degradability of $\mathrm{NaOH}$-treated corn stover than that of untreated corn stover (Jami et al., 2014). There is no doubt that dairy cows consuming $\mathrm{NaOH}$-treated corn stover have a better performance than cows consuming untreated corn stover (Jami et al., 2014). Whether the income from higher milk production can compensate the DM loss, especially hemicellulose loss during treatment, and the cost of labor, machinery and $\mathrm{NaOH}$ should be taken into consideration. In addition, the application of $\mathrm{NaOH}$ can be a cause of environmental pollution, resulting in a high content of sodium in the environment.

Lime (calcium oxide $(\mathrm{CaO})$ or calcium hydroxide) treatment: Compared with $\mathrm{NaOH}-$ treatment, lime is less expensive and is safer to use and handle by unskilled workers. As lime contains calcium, using lime to treat corn stover can also save on mineral additive costs. The degradability of corn stover increases after treatment due to the improved accessibility of carbohydrates to rumen microorganisms, which results from the weakening of the lignocellulosic structure of corn stover when treated with lime (Shi et al., 2015a). Recent research has shown that feeding diets containing a portion of $\mathrm{CaO}$-treated corn stover and dried distillers grains with solubles can improve the profitability without negatively affecting the lactation performance of mid- to latelactation cows (Shi et al., 2015a, b).

Urea and ammonia treatment: Treatment of corn stover with ammonia, including anhydrous and aqueous ammonia, urea and urine, have been demonstrated to improve 
the degradability effectively. These treatments can increase the stover degradability by breaking the links between the lignin and the carbohydrates from the cell walls in corn stover (Colenbrander et al., 1971; Sewalt et al., 1996; Alemu et al., 2005; Anastacio et al., 2009; $\mathrm{Xu}$ et al., 2013), but the effect is not as strong as the $\mathrm{NaOH}$ and $\mathrm{CaO}$ treatments (Liu et al., 2002). Additional benefits from these treatments are improvement in $\mathrm{N}$ content, which saves the cost of purchasing protein-rich feedstuffs and preserves the stover by inhibiting mould growth. Currently urea treatment is better than ammonia and urine treatment due to the potential danger for farmers using anhydrous or aqueous ammonia and the hygienic problems from usage of urine.

\subsubsection{Biological treatment}

At a laboratory scale, research has already been conducted on using fungi and/or their enzymes to pretreat corn stover to improve its degradability (Karunanandaa et al., 1992; Chen et al., 1995; Yang and Xie, 2010; Khan et al., 2015a). However, wide application of fungi treated stover in dairy farms may not be feasible due to the long treatment time and potential carbohydrate losses during fungal treatment, which can be optimized by selecting the most effective strain, the right substrate and culture conditions. Compared with the fungi treatment method, adding fibrolytic enzymes has already shown improvement in fiber degradation and DM intake in dairy cattle, but the responses to the use of these enzyme products are variable.

White-rot fungi treatment: The process of delignification of crop residues by fungi can be divided into two phases. The relatively easily accessible components, such as starch, pectin and hemicellulose are utilized by the fungi during the first phase and the IVGP of the crop residues decreases due to degradation of these easily accessible carbohydrates. The second phase is the delignification phase and the IVGP starts to increase due to the degradation of lignin and consequent potential accessibility to cellulose and hemicellulose. During the second phase, hemicellulose can also be degraded and used as an energy source for the growth of fungi and for the production of enzymes (Van Kuijk et al., 2017). As suggested by Buranov and Mazza (2008), the degradation of hemicellulose may not be avoided during the process of delignification since hemicellulose and lignin are linked by the ether bonds. Van Kuijk et al. (2017) reported a decrease in the absolute amount of cellulose in the second phase, which 


\section{CHAPTER 1}

resulted from cellulases secreted, but the remaining cellulose was better accessed by the rumen microorganisms leading to an increase in IVGP. For corn stover or corn stems, although different fungi are capable to degrade lignin during incubation for six weeks or longer, hemicellulose and cellulose which can be degraded by rumen microorganisms may also be utilized by the fungi (Tuyen et al., 2013; Lynch et al., 2014). In previous studies, Chen et al. (1995) reported that the in vitro DM degradability (IVDMD) of corn stover can be significantly improved after incubation with Cyathus stercoreus and Phlebia brevispora for 28 d. Karunanandaa et al. (1992) found that $C$. stercoreus can increase the IVDMD of corn stover after incubation for $30 \mathrm{~d}$. However, the degradability of corn stems was not enhanced by treatment with Pleurotus ostreatus or Trametes versicolor for 1, 2, 3 and 4 months (Lynch et al., 2014). Although the IVGP of corn stover did not increase after 6 weeks treatment with Lentinula edodes and Pleurotus eryngii (Tuyen et al., 2013), it is unknown whether the degradation of the least degradable part of corn stover can be increased by L. edodes and P. eryngii with more than 6 weeks treatment.

Exogenous fibrolytic enzymes: There are numerous enzymes contributing to degrading cellulose and hemicellulose by rumen microbes. Cellulases and xylanase are the mainchain degrading polysaccharide hydrolases and feruloyl acid esterase and acetyl esterase are the side-chain degrading esterases (Glass et al., 2013). However, not all the enzymes, which are involved in the fiber degradation, are included in commercial exogenous fibrolytic enzyme products, with the most commonly added enzymes being cellulase, xylanase and $\beta$-glucanase (Yang and Xie, 2010). Although the effect of

fibrolytic enzymes on improving fiber degradation of corn stover has been demonstrated by in vitro methods (Yang and Xie, 2010; Zhao et al., 2015; Vallejo et al., 2016), the enzymes (cellulase and xylanase) cannot hydrolyze the linkages between phenolic acids and lignin, which are the main constraints to greater ruminal fiber degradation (Adesogan et al., 2014). The optimal combination of xylanase, cellulase, $\beta$-glucanase and feruloyl acid esterase should be considered to enhance cell wall degradation of corn stover (Yang and Xie, 2010).

\subsection{Thesis objectives and outline}

As stated above, with corn grains used as food and feed, as well as the ethanol industry, 
large amounts of corn stover are generated every year of which more than half are burned on the field. The low degradability of corn stover impedes the inclusion of corn stover in the ration of dairy cows. Since adding corn stover to the ration of dairy cows may increase the profit of dairy farms, alleviate environmental pollution caused by burning corn stover on the field and improve land use efficiency, it is necessary to find ways to increase the degradability of corn stover and evaluate its economic feasibility. Inconsistencies and gaps exist in current knowledge that limit the ability to use corn stover in an optimal way, as indicated in the previous paragraphs. These include: insufficient knowledge on NDF degradability of leaves and stems separately; insufficient knowledge on factors related to corn stem ADL characteristics (ADL content or ADL composition) that determine cell wall degradability of corn stems; inconsistencies in knowledge on effects of fungal treatment on stem cell wall degradability. Based on these inconsistencies and knowledge gaps, the general objective of this thesis was to improve the utilization of corn stover in dairy farms in China through evaluating cell wall degradability in vitro and incubating the least degradable part of corn stover with fungi, followed by an economic evaluation including consequences of corn stover inclusion in dairy cattle rations for the food feed competition, methane emission, and milk $\mathrm{N}$ efficiency.

Exploring the least degradable part of corn stover is the first aim of the thesis. The cell wall degradability, which is assessed by the IVGP technique, of corn leaves and stems and the relationship between chemical composition and cell wall degradation were investigated (Chapter 2). The cell wall degradation of corn leaves was greater than that of corn stems, for most cultivars investigated. Subsequently, the cell wall degradation of different internodes from the stems and the internodes harvested at different days was studied (Chapter 3), in order to find the least degradable part of stems and to evaluate which factor (lignin content and composition) is more decisive for the cell wall degradation of corn stems.

The second aim of the thesis was to explore whether fungal treatment and ensiling can enhance the cell wall degradation of the lower part of the stem. The lower part of the stem was chosen for evaluation, as the degradability of the lower part of the stem is smaller than that of the higher part of the stem. The changes in chemical composition and degradability of the stems during ensiling and upon fungal treatment were investigated as described in Chapter 4. 


\section{CHAPTER 1}

The third aim of the thesis was to determine the proper ratio of corn plants used as whole plant corn silage and corn stover silage, to maximize the profit of dairy farmers, using an optimization model. The consequences with respect to corn grain available for other purposes (including available for human consumption), land use efficiency, enteric methane production and milk $\mathrm{N}$ efficiency were also evaluated (Chapter 5). Finally, the results of the previous chapters are discussed and suggestions for further research are presented (Chapter 6).

\subsection{References}

Adesogan, A.T., Ma, Z.X., Romero, J.J., Arriola, K.G., 2014. Ruminant nutrition symposium: Improving cell wall digestion and animal performance with fibrolytic enzymes. J. Anim. Sci. 92, 1317-1330.

Adler, E., 1977. Lignin chemistry-Past, present and future. Wood Sci. Technol. 11, 169218.

Agbor, V.B., Cicek, N., Sparling, R., Berlin, A., Levin, D.B., 2011. Biomass pretreatment: Fundamentals toward application. Biotechnol. Adv. 29, 675-685.

Albornoz, R.I., Allen, M.S., 2018. Highly fermentable starch at different diet starch concentrations decreased feed intake and milk yield of cows in the early postpartum period. J. Dairy Sci. 101, 8902-8915.

Alemu, T., Chairatanayuth, P., Vijchulata, P., Tudsri, S., 2005. The potential of urea treated maize stover for growth performance of weaned crossbred calves. Kasetsart J. Nat. Sci. 39, 638-646.

Anastacio, G.M., Benito, A.P., Octavio, A.C.O., Angelica, E.O., Carlos, M.A.J., 2009. Urea treated maize straw for small-scale dairy systems in the highlands of central Mexico. Trop. Anim. Health Prod. 41, 1487-1494.

Arora, D.S., Sharma, R., 2009. Enhancement in in vitro digestibility of wheat straw obtained from different geographical regions during solid state fermentation by white rot fungi. Bioresour. 4, 909-920.

Boon, E.J.M.C., Engels, F.M., Struik, P.C., Cone, J.W., 2005. Stem characteristics of two forage maize (Zea mays L.) cultivars varying in whole plant digestibility. II. 
Relation between in vitro rumen fermentation characteristics and anatomical and chemical features within a single internode. Netherlands J. Agric. Sci.-Wageningen J. Life Sci. 53, 87-109.

Boon, E.J.M.C., Struik, P.C., Tamminga, S., Engels, F.M., Cone, J.W., 2008. Stem characteristics of two forage maize (Zea mays L.) cultivars varying in whole plant digestibility. III. Intra-stem variability in anatomy, chemical composition and in vitro rumen fermentation. Netherlands J. Agric. Sci.-Wageningen J. Life Sci. 56, 101-122.

Budakli Carpici, E., Celik, N., Bayram, G., 2010. Yield and quality of forage maize as influenced by plant density and nitrogen rate. Turk. J. Field Crops. 15, 128-132.

Buranov, A.U., Mazza, G., 2008. Lignin in straw of herbaceous crops. Ind. Crop. Prod. 28, 237-259.

Buxton, D.R., Russell, J.R., 1988. Lignin constituents and cell wall digestibility of grass and legume stems. Crop Sci. 28, 553-558.

Buza, M.H., Holden, L.A., White, R.A., Ishler, V.A., 2014. Evaluating the effect of ration composition on income over feed cost and milk yield. J. Dairy Sci. 97, 30733080 .

Casler, M.D., Jung, H.G., 2006. Relationships of fibre, lignin, and phenolics to in vitro fibre digestibility in three perennial grasses. Anim. Feed Sci. Technol. 125, 151-161.

Castro, F.B., Hotten, P.M., Orskov, E.R., 1993. The potential of dilute-acid hydrolysis as a treatment for improving the nutritional quality of industrial lignocellulosic byproducts. Anim. Feed Sci. Technol. 42, 39-53.

Chatuvedi, V., Verma, P., 2013. An overview of key pretreatment process employed for bioconversion of lignocellulosic biomass into biofuels and value added products. 3 Biotech. 3, 415-431.

Chen, J., Fales, S.L., Varga, G.A., Royse, D.J., 1995. Biodegradation of cell wall components of maize stover colonized by white-rot fungi and resulting impact on invitro digestibility. J. Sci. Food Agric. 68, 91-98.

Chesson, A., 1993. Mechanistic models of forage cell wall degradation. In: Jung, H.G., Buxton, D.R., Hatfield, R.D., Ralph, J. (Eds.), Forage Cell Wall Structure and Digestibility. ASA-CSSA-SSSA, Madison, WI, USA, pp. 347-376. 


\section{CHAPTER 1}

Colenbrander, V.F., Muller, L.D., Wasson, J.A., Cunningham, M.D., 1971. Effects of added urea and ammonium polyphosphate to corn stover silages on animal performance. J. Anim. Sci. 33, 1091-1096.

Cone, J.W., Engels, F.M., 1993. The influence of ageing on cell wall composition and degradability of three maize genotypes. Anim. Feed Sci. Technol. 40, 331-342.

Ding, S.Y., Liu, Y.S., Zeng, Y.N., Himmel, M.E., Baker, J.O., Bayer, E.A., 2012. How does plant cell wall nanoscale architecture correlate with enzymatic digestibility? Science 338, 1055-1060.

Ebringerova, A., Hromadkova, Z., Heinze, T., 2005. Hemicellulose. Adv. Polym. Sci. $186,1-67$.

Engels, F.M., 1989. Some properties of cell wall layers determining ruminant digestion. In: Chesson, A., Orskov, E.R. (Eds.), Physico-chemical Characterisation of Plant Residues for Industrial and Feed Use. Elsevier Applied Science, London and New York, pp. 80-87.

Engels, F.M., Jung, H.G., 2005. Alfalfa stem tissues: impact of lignifications and cell length on ruminal degradation of large particles. Anim. Feed Sci. Technol. 120, 309321.

Fernandes, T., Avila, C.L.S., Pereira, M.N., Ferraretto, L.F., 2018. Short communication: Effect of washing method, grinding size, and the determination of an indigestible fraction on in situ degradation of starch in mature corn grain. J. Dairy Sci. $101,9052-9057$.

Gao, Y., 2011. Current situation and development police for the corn processing industry in China. Bull. Agric. Sci. Technol. 2, 9-11.

Gibson, L.J., 2012. The hierarchical structure and mechanics of plant materials. J. R. Soc. Interface 9, 2749-2766.

Glass, N.L., Schmoll, Monika., Cate, J.H.D., Coradetti, S., 2013. Plant cell wall deconstruction by Ascomycete fungi. Annu. Rev. Microbiol. 67, 477-498.

Godfray, H.C.J., Beddington, J.R., Crute, I.R., Haddad, L., Lawrence, D., Muir, J.F., Pretty, J., Robinson, S., Thomas, S.M., Toulmin, C., 2010. Food security: the challenge of feeding 9 billion people. Science 327, 812-818. 
Gordon, A.J., Neudoerffer, T.S., 1973. Chemical and in vivo evaluation of a brown midrib mutant of Zea mays. I. Fiber, lignin and amino acid composition and digestibility for sheep. J. Sci. Food Agric. 24, 565-577.

Gordon, A.J., 1975. A comparison of some chemical and physical properties of alkali lignins from grass and lucerne hays before and after digestion by sheep. J. Sci. Food Agric. 26, 1551-1559.

Grabber, J.H., 2005. How do lignin composition, structure and cross-linking affect degradability? A review of cell wall model studies. Crop Sci. 45, 820-831.

Guo, D.G., Chen, F., Wheeler, J., Winder, J., Selman, S., Peterson, M., Dixon, R.A., 2001. Improvement of in-rumen digestibility of alfalfa forage by genetic manipulation of lignin $O$-methyltransferases. Transgenic Res. 10, 457-464.

Hartley, R.D., 1972. P-coumaric and ferulic acid components of cell walls of ryegrass and their relationships with lignin and digestibility. J. Sci. Food Agric. 23, 1347-1354. Hartley, R.D., Ford, C.W., 1989. Cyclodimers of $p$-coumaric and ferulic acids in the cell-walls of tropical grasses. J. Sci. Food Agric. 50, 29-43.

Hendriks, A.T.W.M., Zeeman, G., 2009. Pretreatments to enhance the digestibility of lignocellulosic biomass. Bioresour. Technol. 100, 10-18.

Hoffman, P.C., Esser, N.M., Shaver, R.D., Coblenta, W.K., Scott, M.P., Bodnar, A.L., Schmidt, R.J., Charley, 2011. Influence of ensiling time and inoculation on alteration of the starch-protein matrix in high-moisture corn. J. Dairy Sci. 94, 2465-2474.

Homb, T., 1984. Wet treatment with sodium hydroxide. In: Sundstol, F., Owen, E. (Eds.), Straw and Other Fibrous By-Products as Feed. Elsevier, New York, NY, pp.106124 ,

Hu, Y., Li, W.C., Xu, Y.Q., Li, G.J., Liao, Y., Fu, F.L., 2009. Differential expression of candidate genes for lignin biosynthesis under drought stress in maize leaves. J. Appl. Genet. 50, 213-223.

Inomana, F., Takabe, K., Saiki, H., 1992. Cell wall formation of conifer tracheid as revealed by rapid-freeze and substitution method. Microsc. 41, 369-374.

Islam, M.R., Garcia S.C., Horadagoda, A., 2012. Effects of irrigation and rates and 


\section{CHAPTER 1}

timing of nitrogen fertilizer on dry matter yield, proportions of plant fractions of maize and nutritive value and in vitro gas production characteristics of whole crop maize silage. Anim. Feed Sci. Technol. 172, 125-135.

Jackson, M.G., 1977. Review article: The alkali treatment of straws. Anim. Feed Sci. Technol. 2, 105-130.

Jalc, D., 2002. Straw enrichment for fodder production by fungi. In: Kempken, F. (Ed.), The Mycota XI, Agricultural Application. Springer-Verlag, Berlin, pp. 19-38.

Jami, E., Shterzer, N., Yosef, E., Nikbachat, M., Miron, J., Mizrahi, I., 2014. Effects of including $\mathrm{NaOH}$-treated corn straw as a substitute for wheat hay in the ration of lactating cows on performance, digestibility, and rumen microbial profile. J. Dairy Sci. 97, 1623-1633.

Jeffries, T.W., 1994. Biodegradation of lignin and hemicelluloses. In: Ratledge, C. (Ed.), Biochemistry of Microbial Degradation. Dordrecht Kluwer, pp. 233-277.

Johnson, R.R., Dehority, B.A., Parson, J.L., Scott, H.W., 1962. Discrepancies between grasses and alfalfa when estimating nutritive value from in vitro cellulose degradability by rumen microorganisms. J. Anim. Sci. 21, 892-896.

Jung, H.G. 1989. Forage lignins and their effects on fiber digestibility. Agron. J. 81, 33-38.

Jung, H.G., Buxton, D.R., 1994. Forage quality variation among maize inbreds: relationships of cell-wall composition and in vitro degradability for stem internodes. J Sci Food Agric. 66, 313-322.

Jung, H.G., Deetz, D.A., 1993. Cell wall lignification and degradation. In: Jung, H.G., Buxton, D.R., Hatfield, R.D., Ralph, J. (Eds.), Forage Cell Wall Structure and Digestibility. ASA-CSSA-SSSA, Madison, WI, USA, pp. 315-346.

Jung, H.G., Lamb, J.F.S., 2003. Identification of Lucerne stem cell wall traits related to in vitro neutral detergent fibre digestibility. Anim. Feed Sci. Technol. 110, 17-29.

Jung, H.G., Mertens, D.R., Payne, A.J., 1997. Correlation of acid detergent lignin and Klason lignin with digestibility of forage dry matter and neutral detergent fiber. J. Dairy Sci. $80,1622-1628$. 
CHAPTER 1

Karunanandaa, K., Fales, S.L., Varga, G.A., Royse, D.J., 1992. Chemical composition and biodegradability of crop residues colonized by white-rot fungi. J. Sci. Food Agric. 60, 105-112.

Keys, J.E., Smith, L.W., 1983. Effects of two harvesting methods and grinding on growth, intake, and digestion of corn stover silage diets by yearling dairy heifers. J. Dairy Sci. 66, 1689-1695.

Khan, N.A., Hussain, S., Ahmad, N., Alam, S., Bezabhi, M., Hendriks, W.H., Yu, P., Cone, J.W., 2015a. Improving the feeding value of straws with Pleurotus ostreatus. Anim. Prod. Sci. 55, 241-245.

Khan, N.A., Yu, P., Ali, M., Cone, J.W., Hendriks, W.H., 2015b. Nutritive value of maize silage in relation to dairy cow performance and milk quality. J. Sci. Food Agric. $95,238-252$.

Lascano, G.J., Heinrichs, A.J., 2011. Effects of feeding different levels of dietary fiber through the addition of corn stover on nutrient utilization of dairy heifers precision-fed high and low concentrate diets. J. Dairy Sci. 94, 3025-3036.

Li, S., Yao, K., Cao, Z., Liu, C., Zhang, S., Liu, J., Li, J., Wang, J., Zhang, H., 2018. Dairy Industry and Technical Development Report in 2017. Chinese J. Anim. Sci. 3, 132-137.

Liu X., Li, S., 2017. China dairy trade development. In: Li, S. (Ed.), China dairy white paper (2016). Sino-Dutch Dairy Development Centre, Beijing, China, pp. 54-69.

Liu, J.X., Susenbeth, A., Sudekum, K.H., 2002. In vitro gas production measurements to evaluate interactions between untreated and chemically treated rice straws, grass hay, and mulberry leaves. J. Anim. Sci. 80, 517-524.

Lynch, J.P., O’Kiely, P., Murphy, R., Doyle, E.M., 2014. Changes in chemical composition and digestibility of three maize stover components digested by white-rot fungi. J. Anim. Physiol. Anim. Nutr. 98, 731-738.

MacAdam, J.W., Grabber, J.H., 2002. Relationship of growth cessation with the formation of diferulate cross-links and $p$-courmaroylated lignins in tall fescue leaf blades. Planta 215, 785-793. 


\section{CHAPTER 1}

Moharrery, A., Larsen, M., Weisbjerg, M.R., 2014. Starch digestion in the rumen, small intestine, and hindgut of dairy cows - A meta-analysis. Anim. Feed Sci. Technol. 192, $1-14$.

Mussadiq, Z., Gustavsson, A.M., Geladi, P., Swensson, C., Hetta, M., 2013. Effects of morphological fractions on estimated milk yields in forage maize depending on growing site and plant maturity. Acta Agricult. Scand. Section A. 63, 131-142.

Oba, M., Allen, M.S., 1999. Effects of brown midrib 3 mutation in corn silage on dry matter intake and productivity of high yielding dairy cows. J. Dairy Sci. 82, 135-142.

Olschlager, V., 2007. Molekularbiologische und enzymatische Untersuchungenzum Einfluss von Partikellange und Konzentratanteil auf Parameter der fibrolytischen Pansenverdauung. PhD Diss. Universitat Hohenheim, Hohenheim, Germany.

Raffrenato, E., Fievisohn, R., Cotanch, K.W., Grant, R.J., Chase, L.E., Van Amburgh, M.E., 2017. Effect of lignin linkages with other plant cell wall components on in vitro and in vivo neutral detergent fiber digestibility and rate of digestion of grass forages. J. Dairy Sci. 100, 8119-8131.

Rexen, F.P., Knudsen, K.E.B., 1984. Industrial-scale dry treatment with sodium hydroxide. In: Sundstol, F., Owen, E. (Eds.), Straw and Other Fibrous By-Products as Feed. Elsevier, New York, pp.127-161,

Reynolds, C.K., Huntington, G.B., Tyrrell, H.F., Reynolds, P.J., 1988. Net metabolism of volatile fatty acids, D- $\beta$-hydroxybutyrate, nonesterified fatty acids, and blood gasses by portal-drained viscera and liver of lactating Holstein cows. J. Dairy Sci. 71, 18031812.

Sarkar, N., Ghosh, S.K., Bannerjee, S., Aikat, K., 2012. Bioethanol production from agricultural wastes: An overview. Renew. Energy 37, 19-27.

Sewalt, V.J.H., Fontenot, J.P., Allen, V.G., Glasser, W.G., 1996. Fiber composition and in vitro digestibility of corn stover fractions in response to ammonia treatment. J. Agric. Food Chem. 44, 3136-3142.

Sewalt, V.J.H., Ni, W., Jung, H.G., Dixon, R.A., 1997. Lignin impact on fiber degradation: increased enzymatic digestibility of genetically engineered tobacco (Nicotiana tabacum) stems reduced in lignin content. J Agric Food Chem. 45, 1977- 
1983.

Shi, H.T., Cao, Z.J., Wang, Y.J., Li, S.L., Yang, H.J., Bi, Y.L., Doane, P.H., 2015a. Effects of calcium oxide treatment at varying moisture concentrations on the chemical composition, in situ degradability, in vitro digestibility and gas production kinetics of anaerobically stored corn stover. J. Anim. Physiol. Anim. Nutr. 100, 748-757.

Shi, H.T., Li, S.L., Cao, Z.J., Wang, Y.J., Alugongo, G.M., Doane, P.H., 2015b. Effects of replacing wild rye, corn silage, or corn grain with $\mathrm{CaO}$-treated corn stover and dried distillers grains with solubles in lactating cow diets on performance, digestibility, and profitability. J. Dairy Sci. 98, 7183-7193.

Shi, H.T., Yang, J.X., Tian, Y.J., Huang, W.M., Bi, Y.L., Cao, Z.J., Li, S.L., 2012. Discussion of the development and utilization of the nutrition value of corn stover-rich and low-cost resources but haven't been fully exploited. China Dairy Cattle 17, 3-11.

Susmel, P., Stefanon, B., 1993. Aspects of lignin degradation by rumen microorganisms. J. Biotechnol. 30, 141-148.

Tanahashi, M., Higuchi, T., 1989. Chemical degradation methods for characterization of lignins. Meth. Enzymol. 161, 101-109.

Tang, S.X., Gan, J., Sheng, L.X., Tan, Z.L., Tayo, G.O., Sun, Z.H., Wang, M., Ren, G.P., 2008. Morphological fractions, chemical composition and in vitro fermentation characteristics of maize stover of five genotypes. Anim. 2, 1772-1779.

Tang, S.X., Sheng, L.X., Tan, Z.L., Tayo, G.O., Liao, H.Y., Sun, Z.H., Zeng, B., Han, X.F., Zhou, C.S., Ren, G.P., 2009. Morphological fractions and in vitro fermentation characteristics of five endosperm types maize stover harvested at two maturity stages. J. Anim. Feed Sci. 18, 582-598.

Terashima, N., Fukushima, K., 1988. Heterogeneity in formation of lignin XI. An autoradiographic study of the heterogeneous formation and structure of pine lignin. Wood Sci. Technol. 22, 259-270.

Terashima, N., Fukushima, K., 1989. Biogenesis and structure of macromolecular lignin in the cell wall of tree xylem as studied by microautoradiography. In: Lewis, N.G., Paice, M.G. (Eds.), Plant cell wall polymers, biogenesis and biodegradation. ACS Symp. Ser. 399. Am. Chem. Soc., Washington, DC, pp.160-168. 


\section{CHAPTER 1}

Terashima, N., Fukushima, K., He, L.F., Takabe, K., 1993. Comprehensive model of the lignified plant cell wall. In: Jung, H.G., Buxton, D.R., Hatfield, R.D., Ralph, J. (Eds.) Forage Cell Wall Structure and Digestibility. ASA-CSSA-SSSA, Madison, WI, USA, pp. 247-270.

Tolera, A., Berg, T., Sundstol, F., 1999. The effect of variety on maize grain and crop residue yield and nutritive value of the stover. Anim. Feed Sci. Technol. 79, 165-177.

Tolera, A., Sundstol, F., 1999. Morphological fractions of maize stover harvested at different stages of grain maturity and nutritive value of different fractions of the stover. Anim. Feed Sci. Technol. 81, 1-16.

Tuyen, V.D., Cone, J.W., Baars, J.J.P., Sonnenberg, A.S.M., Hendriks, W.H., 2012. Fungal strain and incubation period affect chemical composition and nutrient availability of wheat straw for rumen fermentation. Bioresour. Technol. 111, 336-342. Tuyen, V.D., Phuong, H.N., Cone, J.W., Baars, J.J.P., Sonnenberg, A.S.M., Hendriks, W.H., 2013. Effect of fungal treatments of fibrous agricultural by-products on chemical composition and in vitro rumen fermentation and methane production. Bioresour. Technol. 129, 256-263.

Vallejo, L.H., Salem, A.Z.M., Kholif, A.E., Elghangour, M.M.Y., Fajardo, R.C., Rivero, N., Bastida, A.Z., Mariezcurrena, M.D., 2016. Influence of cellulase or xylanase on the in vitro rumen gas production and fermentation of corn stover. Indian J. Anim. Sci. 86, 70-74.

Vanholme, R., Demedts, B., Morreel, K., Ralph, J., Boerjan, W., 2010. Lignin biosynthesis and structure. Plant Physiol. 153, 895-905.

Van Kuijk, S.J.A., Del Rio, J.C., Rencoret, J., Gutierrez, A., Sonnenberg, A.S.M., Baars, J.J.P., Hendriks, W.H., Cone, J.W., 2016. Selective ligninolysis of wheat straw and wood chips by the white-rot fungus Lentinula edodes and its influence on in vitro rumen degradability. J. Anim. Sci. Biotechnol. 7, 55-68.

Van Kuijk, S.J.A., Sonnenberg, A.S.M., Baars, J.J.P., Hendriks, W.H., Cone, J.W., 2015. Fungal treatment of lignocellulosic biomass: importance of fungal species, colonization and time on chemical composition and in vitro rumen degradability. Anim. Feed Sci. Technol. 209, 40-50. 
Van Kuijk, S.J.A., Sonnenberg, A.S.M., Baars, J.J.P., Hendriks, W.H., Del Rio, J.C., Rencoret, J., Gutierrez, A., De Ruijter, N.C.A., Cone, J.W., 2017. Chemical changes and increased degradability of wheat straw and oak wood chips treated with the white rot fungi Ceriporiopsis subvermispora and Lentinula edodes. Biomass Bioenergy 105, 381-391.

Verbic, J., Stekar, J.M.A., Resnik-Cepon, M., 1995. Rumen degradation characteristics and fibre composition of various morphological parts of different maize hybrids and possible consequences for breeding. Anim. Feed Sci. Technol. 54, 133-148.

Wang, B., Mao, S.Y., Yang, H.J., Wu, Y.M., Wang, J.K., Li, S.L., Shen, Z.M., Liu, J.X., 2014. Effects of alfalfa and cereal straw as a forage source on nutrient digestibility and lactation performance in lactating dairy cows. J. Dairy Sci. 97, 7706-7715.

Weber, I., 2007. Effekte von Partikellange, Faseranteil und Fermentierbarkeit von Rationen fur Milchkuhe auf Parameter der ruminalen Toleranz. PhD Diss. Universitat Hohenheim, Hohenheim, Germany.

Wilkinson, J.M. 1984. Farm scale dry treatments with sodium hydroxide. Location and potential feed use. In: Sundstol, F., Owen, E. (Eds.), Straw and Other Fibrous ByProducts as Feed. Elsevier, New York, pp.162-180,

Wilson, J.R., Mertens, D.R., 1995. Cell wall accessibility and cell structure limitations to microbial digestion of forage. Crop Sci. 35, 251-259.

Xu, X.F., Tian, Y.J., Guo, Y.Q., Li, S.L., Cao, Z.J., 2013. Effect of molasses addition on in vitro rumen degradability and microbial protein synthesis of corn stover treated with sodium hydroxide and urea. J. Food Agric. Environ. 11, 1233-1238.

Yang, H.J., Xie, C.Y., 2010. Assessment of fibrolytic activities of 18 commercial enzyme products and their abilities to degrade the cell wall fraction of corn stalk in in vitro enzymatic and ruminal batch cultures. Anim. Feed Sci. Technol. 159, 110-121.

Yang, L., Gao, Y., 2016. Bottlenecks of efficient utilization of corn straw feed and its solutions. J. Jilin Agri. Univ. 38, 634-638.

Zebeli, Q., Aschenbach, J.R., Tafaj, M., Boguhn, J., Ametaj, B.N., Drochner, W., 2012. Invited review: Role of physically effective fiber and estimation of dietary fiber adequacy in high-producing dairy cattle. J. Dairy Sci. 95, 1041-1056. 


\section{CHAPTER 1}

Zebeli, Q., Tafaj, M., Junck, B., Olschlager, V., Ametaj, B.N., Drochner, W., 2008. Evaluation of the response of ruminal fermentation and activities of non-starch polysaccharide-degrading enzymes to particle length of corn silage in dairy cows. J. Dairy Sci. 91, 2388-2398.

Zhao, L., Peng, Y., Wang, J., Liu, J., 2015. Effects of exogenous fibrolytic enzyme on in vitro ruminal fiber digestion and methane production of corn stover and corn stover based mixed diets. Life Sci. J. 12.

Zhu, W., Fu, Y., Wang, B., Wang, C., Ye, J.A., Wu, Y.M., Liu, J.X., 2013. Effects of dietary forage sources on rumen microbial protein synthesis and milk performance in early lactating dairy cows. J. Dairy Sci. 96, 1727-1734.

Zuo, X., Wang, H., Wang, Y., Wang, L., Jing, L., Wang, D., 2015. Estimation and suitability evaluation of corn straw resources in China. Chin. J. Agri. Resour. Reg. Plann. 36, 5-10. 


\section{Chapter 2}

\section{Relationships between chemical composition and in vitro gas production parameters of corn leaves and stems}

Yuan He, John W. Cone, Wouter H. Hendriks, Jan Dijkstra

Animal Nutrition Group, Wageningen University \& Research, PO Box 338, $6700 \mathrm{AH}$ Wageningen, the Netherlands

Submitted to Journal of Animal Physiology and Animal Nutrition 


\title{
CHAPTER 2
}

\begin{abstract}
This study investigated the chemical composition and in vitro gas production parameters of corn leaves and stems separately, and to relate the in vitro gas production parameters with the chemical composition, of thirteen corn cultivars. After harvest in September 2016, all plants were separated into two morphological fractions: leaves and stems. The crude protein (CP) content was greater, and the ratio of acid detergent lignin (ADL) to potentially rumen degradable fiber (calculated as the difference between neutral detergent fiber and ADL; ADL:pRDF) was lower in the leaves than in the stems, of all 13 cultivars. For the leaves, the cumulative gas production between 3 and $20 \mathrm{~h}$ (A2), representing cell wall fermentation in rumen fluid, and the cumulative $72-\mathrm{h}$ gas production (GP72), representing total organic matter (OM) degradation, were moderately to weakly correlated with the chemical composition $\left(\mathrm{R}^{2}<0.40\right)$, whilst the optimal relationship between the half-time value (B2), representing the rate of cell wall degradation, and chemical composition had an $\mathrm{R}^{2}$ of 0.63 . For the stems, the optimal relationship between A2, B2 and GP72 with chemical composition was greater $\left(\mathrm{R}^{2} \geq\right.$ 0.74 ) and the optimal relationship included hemicellulose (A2 only), cellulose and ADL (GP72 and A2 only). Corn leaves and stems differed in chemical composition, in particular CP content and ADL:pRDF. The A2 and GP72 of the stems, but not of the leaves, were highly correlated to the chemical composition, indicating that the cell wall and $\mathrm{OM}$ degradation of corn stems can be better predicted by its chemical composition.
\end{abstract}

Keywords: corn leaves, corn stems, in vitro gas production, cell wall degradation 
CHAPTER 2

\subsection{Introduction}

Crop residues are important roughage sources for ruminant animals, in particular where grassland is limited. Corn stover, the residue after harvesting the corn grains, is abundant in many countries, including China. Efficient utilization of corn stover by ruminants may decrease feed costs of the farmers due to its low price, and alleviate the environmental burden caused by burning these residues on the field. In China, no more than $30 \%$ of the total corn stover was reported to be fed to ruminant animals mainly due to its low degradability (Lv et al., 2013). Corn stover consists of leaves and stems and the dry matter (DM) degradability of the stems, measured by incubation in nylon bags for $48 \mathrm{~h}$ in the rumen of cattle or sheep, has been shown to be lower than that of the leaves (Harika and Sharma, 1994; Verbic et al., 1995), which may enable more efficient use of corn stover by separating leaves and stems. However, in most previous studies, the leaves and stems were separated into different fractions including leaf sheath and leaf blade, and stem rind and stem pith (Tolera et al., 1999; Tolera and Sundstol, 1999; Tang et al., 2006, 2008, 2009; Li et al., 2014), which may not be feasible and applicable on farm. Considering the impact of variation in chemical composition and degradation on the nutritive value of ruminant feeds (Getachew et al., 2004), research needs to be conducted on the chemical composition and degradation of the leaves and the stems of corn stover.

Cell wall degradation is critical to evaluate forage quality. Due to the difficulties in quantifying the cell wall content exactly, the neutral detergent fiber (NDF) content is considered to be a rapid way to estimate the cell wall content (Theander and Westerlund, 1993). The NDF degradation, therefore, represents the cell wall degradation of the leaves and the stems. It is suggested that NDF degradability of forages is positively correlated with voluntary DM intake and fat corrected milk yield of dairy cows (Oba and Allen, 1999a). Oba and Allen (1999b) proposed that the NDF fraction with greater degradability will leave the rumen at a greater rate, thus facilitating a greater DM and NDF intake, which stimulates milk yield (Kendall et al., 2009). However, Warner et al. (2013) did not observe a relationship between in situ fractional degradation rates of DM or acid detergent fiber (ADF) and their fractional rumen passage rates using intrinsically ${ }^{13} \mathrm{C}$-labeled corn silage. To our knowledge, there are no reports on the cell wall degradability of the leaves and the stems of corn stover. Although both NDF and $\mathrm{ADF}$ content in the leaves and the stems of corn stover were reported to be significantly 


\section{CHAPTER 2}

correlated with the effective DM degradability of the leaves and stems (Verbic et al., 1995), it is unknown whether these fiber components are correlated with the cell wall degradability of the leaves and the stems of corn stover. More information on these relationships may help to improve prediction of the cell wall degradability based on the fiber components of the leaves and the stems of corn stover, resulting in a better utilization of corn stover as a ruminant forage.

The objectives of the present study were to determine the cell wall degradability, which was evaluated by the in vitro gas production technique of the leaves and the stems of corn stover and to describe the relationships between chemical composition and the cell wall degradability of the leaves and the stems of corn stover of several corn cultivars.

\subsection{Materials and Methods}

\subsubsection{Corn plants}

Whole corn plants of 13 cultivars were collected from a trial field of Limagrain (Rilland, the Netherlands) in Wouw, the Netherlands. Seeds were sown on 2 May 2016 to achieve a plants sowing density of $95000 / \mathrm{ha}$. The fields had a sandy soil with $\mathrm{pH} 5.7,40 \mathrm{~g} / \mathrm{kg}$ organic matter $(\mathrm{OM})$ and adequate levels of macro- and micronutrients. The fields were fertilized with $35 \mathrm{~m}^{3} \mathrm{ha}^{-1}$ of cattle manure, $31 \mathrm{~kg} /$ ha of nitrogen, $10 \mathrm{~kg} / \mathrm{ha}$ of phosphorus and $0.6 \mathrm{~kg} / \mathrm{ha}$ of boron. From each cultivar, 30 plants were harvested and 4 of the 30 plants were randomly selected and allocated to one of two duplicates. The ears, including the husks, grains, and cobs were removed. After separating the leaves from the stems, both the leaves and the stems were chopped into $1 \mathrm{~cm}$ and each duplicate weighed before being stored separately at $-20^{\circ} \mathrm{C}$ pending freeze drying. After drying, all the leaves and stems per cultivar duplicate were ground separately to pass a $1 \mathrm{~mm}$ sieve using a Peppink 100 AN cross beater mill (Peppink, Deventer, the Netherlands) and stored at room temperature until chemical analysis and in vitro gas production.

\subsubsection{Chemical analysis}

Dry matter content was determined after $4 \mathrm{~h}$ at $103{ }^{\circ} \mathrm{C}$ in an oven. Ash content was determined after combustion for $3 \mathrm{~h}$ at $550{ }^{\circ} \mathrm{C}$ in a muffle furnace. The NDF content 
was determined with a heat-resistant amylase according to Van Soest, Robertson and Lewis (1991). and the ADF and acid detergent lignin (ADL) content were determined according to Van Soest and McQueen (1973). All fiber fractions were expressed excluding residual ash. The hemicellulose content was calculated as the difference between NDF and ADF. The cellulose content was calculated as the difference between ADF and ADL. The difference between NDF and ADL was defined as potentially rumen degradable fiber (pRDF). Nitrogen $(\mathrm{N})$ was determined by the Kjeldahl method and crude protein $(\mathrm{CP})$ was calculated as $\mathrm{N} \times 6.25$.

\subsubsection{In vitro gas production}

The in vitro gas production technique was performed according to the procedure described by Cone et al. (1996). Rumen fluid was collected $2 \mathrm{~h}$ after the morning feeding from three non-lactating rumen fistulated cows fed a grass silage based diet twice daily. The fluid was pooled, stored in a warm insulated flask, pre-filled with $\mathrm{CO}_{2}$, filtered through cheesecloth, and mixed with an anaerobic buffer/mineral solution as described by Cone et al. (1996) under continuous flushing with $\mathrm{CO}_{2}$. A carefully weighed amount of OM ( $\sim 0.5 \mathrm{~g})$ of the freeze-dried samples were incubated with $60 \mathrm{ml}$ buffered rumen fluid (one part of rumen fluid and two parts of buffer) in $250 \mathrm{ml}$ bottles at $39{ }^{\circ} \mathrm{C}$ in a shaking water bath. Each sample was run in one bottle each time and each sample was run twice during separate weeks. Gas production was recorded for $72 \mathrm{~h}$ with an automated system and values expressed on an OM basis.

Cumulative gas production data were fitted to a three phasic mathematical model as described by Groot et al. (1996) using the NLIN procedure in SAS 9.3. The gas production curves were divided into three different sub-curves, each with an asymptote (A), a half-time value (B) and a shape parameter (C). Sub-curve 1 corresponds to the gas production between 0 and $3 \mathrm{~h}$ incubation, caused by fermentation of the watersoluble components. Sub-curve 2 corresponds to the gas production between 3 and 20 h caused by fermentation of the non-soluble components (Cone et al., 1997). The halftime value $\mathrm{B} 2$ is the incubation time $(\mathrm{h})$ needed to reach half of $\mathrm{A} 2$, representing a measure for the rate of cell wall degradation. To enable robust curve fitting, A1 was set as the cumulative gas production at $3 \mathrm{~h}$, and $\mathrm{A} 2$ was set as the cumulative gas production at $20 \mathrm{~h}$, minus that at $3 \mathrm{~h}$ (Van Gelder et al., 2005). 


\section{CHAPTER 2}

\subsubsection{Statistical analysis}

The data were analyzed using the PROC GLM procedure of SAS/STAT ${ }^{\circledR} 9.3$ (Statistical Analysis System, Cary, NC, USA). The model included corn cultivar $(\mathrm{n}=$ 13), morphological fractions (leaves and stems), their interactions as fixed effects and a week effect. The latter was shown to be not significant and removed from the model. Differences among main effects were analyzed using the Tukey-Kramer's multiple comparison procedure. Regression equations were derived to predict A2, B2 and cumulative gas production at $72 \mathrm{~h}$ (GP72) from each chemical component and selected variables, using the stepwise selection method (PROC REG procedure of SAS 9.3, 2011) with $P \leq 0.05$ as the significance level for the variables to enter or stay in the model.

\subsection{Results}

The content of ash, $\mathrm{CP}, \mathrm{NDF}, \mathrm{ADF}, \mathrm{ADL}$, and the rest fraction, as well as the ratio of ADL to pRDF (ADL:pRDF) of the leaves and the stems of the 13 corn cultivars are shown in Table 2.1. The ash content in the leaves was greater than that in the stems for all the cultivars, except $\operatorname{Lg} 30218 \mathrm{bm}$. The leaves of all the cultivars contained more CP and had a lower ADL:pRDF than the stems. The NDF content in the leaves of Lg30248, Lg31269, Pauleen and Perley was greater than in the stems, whereas for Asgarrd, Claudini, Lg30218bm, Lg31211 and Lg3216, the NDF content was lower in the leaves than in the stems. There were five cultivars, viz. Lg30217, Lg30248, Lg31269, Pauleen and Perley containing similar amounts of ADF in the leaves and in the stems, with the other cultivars having more ADF content in the stems. The ADL content was significantly lower in the leaves than in the stems for all the cultivars, except $\operatorname{Lg} 30248$.

The in vitro gas production parameters of the leaves and the stems are also shown in Table 2.1. There were five cultivars (Lg30248, Lg31211, Lg31269, Pauleen, and Perley) with a greater A1 of the stems than of the leaves. The leaves showed a greater A2 than the stems, except for cultivars Asgaard, Lg30217, Lg31269, and Perley, where A2 of leaves did not differ from that in stems. Leaves had a similar GP72 as stems, except for Claudini, Lg30218bm, and Lg3216, where GP72 was greater for leaves than for stems. The B2 of the leaves was greater than the stems for 11 cultivars, with no significant difference between the leaves and the stems of Grosso and Palmer. 
CHAPTER 2

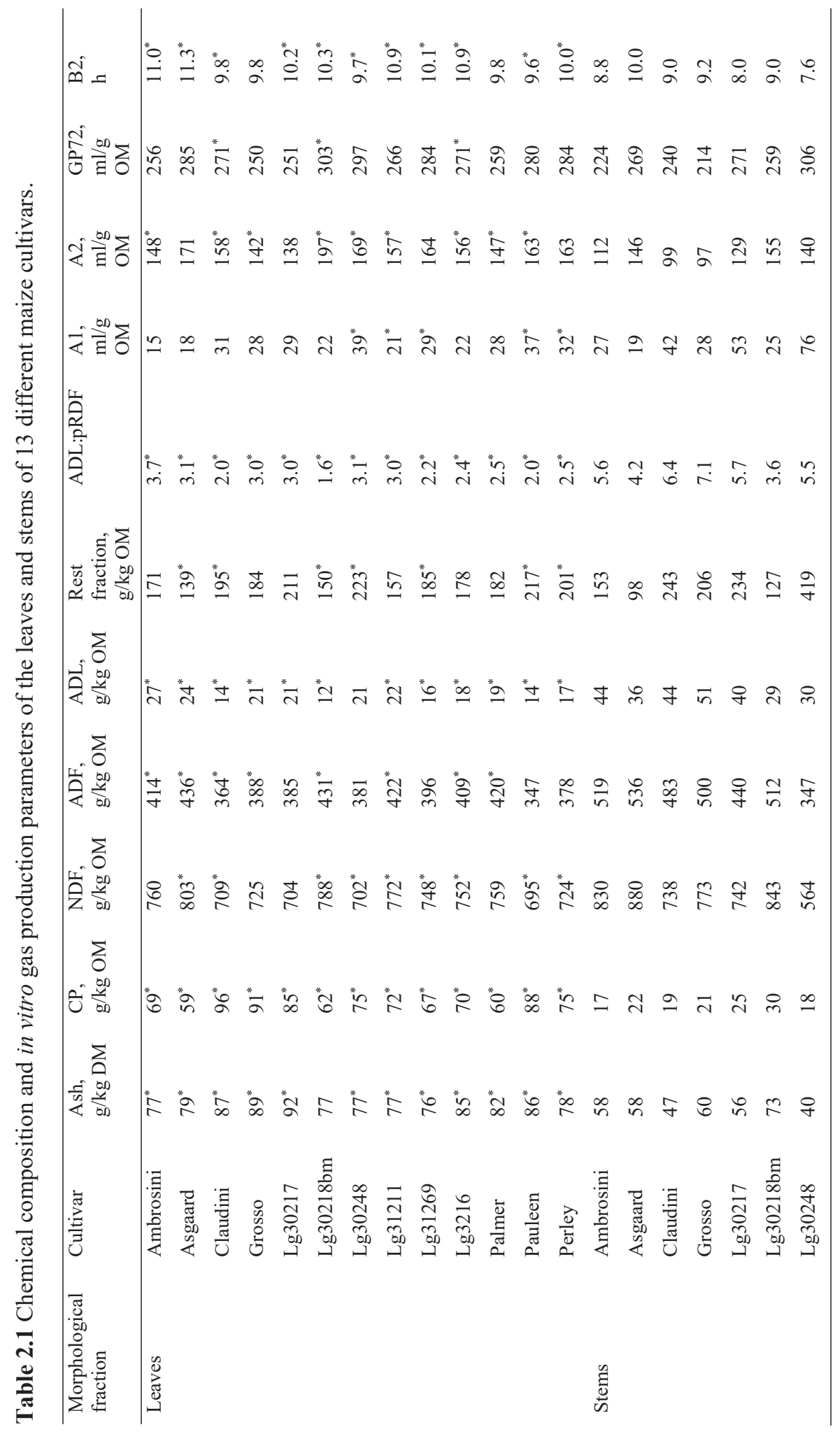




\section{CHAPTER 2}

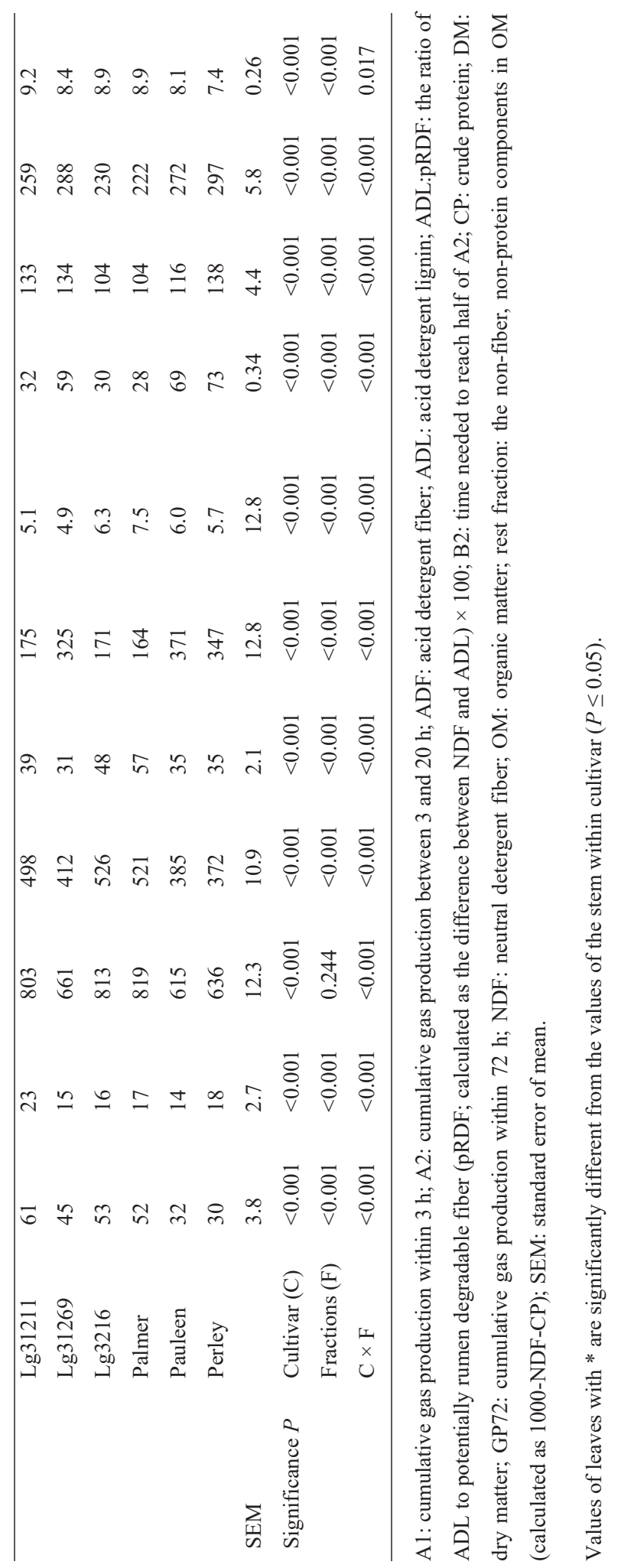


CHAPTER 2

Table 2.2 Total dry matter (TDM) and organic matter (TOM) weight (g/plant) of a stover plant and the total cell wall degradability (A2 $\times$ TOM, L/plant) as well as total organic matter degradability (GP72 $\times$ TOM, L/plant) of a stover plant for 13 different maize cultivars.

\begin{tabular}{|c|c|c|c|c|c|}
\hline \multirow{2}{*}{$\begin{array}{l}\text { Morphological } \\
\text { fraction }\end{array}$} & \multirow[t]{2}{*}{ Cultivar } & \multirow[t]{2}{*}{ TDM } & \multirow[t]{2}{*}{ TOM } & \multicolumn{2}{|l|}{ Degradability } \\
\hline & & & & Total cell wall & Total organic matter \\
\hline \multirow[t]{13}{*}{ Leaves } & Ambrosini & 33.3 & 30.7 & 4.6 & 7.9 \\
\hline & Asgaard & 36.4 & 33.5 & 5.7 & 9.5 \\
\hline & Claudini & 48.7 & 44.5 & 7.0 & 12.1 \\
\hline & Grosso & $45.8^{*}$ & $41.7^{*}$ & $6.0^{*}$ & $10.5^{*}$ \\
\hline & $\operatorname{Lg} 30217$ & 45.2 & 41.1 & 5.7 & 10.4 \\
\hline & Lg30218bm & $39.2^{*}$ & $36.2^{*}$ & $7.2^{*}$ & $11.0^{*}$ \\
\hline & $\operatorname{Lg} 30248$ & 53.1 & 49.1 & 8.3 & 14.6 \\
\hline & Lg31211 & 32.5 & 30.0 & $4.7^{*}$ & $8.0^{*}$ \\
\hline & $\operatorname{Lg} 31269$ & 44.0 & 40.6 & 6.7 & 11.6 \\
\hline & $\operatorname{Lg} 3216$ & 38.1 & 34.8 & $5.5^{*}$ & 9.5 \\
\hline & Palmer & 46.7 & 42.9 & $6.3^{*}$ & 11.2 \\
\hline & Pauleen & $53.2^{*}$ & $48.6^{*}$ & 8.0 & 13.6 \\
\hline & Perley & 43.5 & 40.2 & 6.6 & 11.4 \\
\hline \multirow[t]{13}{*}{ Stems } & Ambrosini & 28.8 & 27.2 & 3.1 & 6.1 \\
\hline & Asgaard & 29.1 & 27.4 & 4.0 & 7.4 \\
\hline & Claudini & 62.5 & 59.7 & 5.9 & 14.3 \\
\hline & Grosso & 39.9 & 37.5 & 3.7 & 8.0 \\
\hline & Lg30217 & 49.3 & 46.5 & 6.0 & 12.7 \\
\hline & Lg30218bm & 24.4 & 22.6 & 3.5 & 5.9 \\
\hline & Lg30248 & 54.3 & 52.2 & 7.3 & 16.0 \\
\hline & $\operatorname{Lg} 31211$ & 24.7 & 23.2 & 3.1 & 6.1 \\
\hline & $\operatorname{Lg} 31269$ & 41.8 & 39.9 & 5.4 & 11.5 \\
\hline & $\operatorname{Lg} 3216$ & 40.4 & 38.3 & 4.0 & 8.8 \\
\hline & Palmer & 49.7 & 47.2 & 5.0 & 10.5 \\
\hline & Pauleen & 69.4 & 67.2 & 7.8 & 18.3 \\
\hline & Perley & 43.0 & 41.7 & 5.8 & 12.4 \\
\hline SEM & & 2.15 & 2.16 & 0.30 & 0.60 \\
\hline \multirow[t]{3}{*}{ Significance $P$} & Cultivar (C) & $<0.001$ & $<0.001$ & $<0.001$ & $<0.001$ \\
\hline & Fractions $(\mathrm{F})$ & 0.835 & 0.140 & $<0.001$ & 0.299 \\
\hline & $\mathrm{C} \times \mathrm{F}$ & $<0.001$ & $<0.001$ & $<0.001$ & $<0.001$ \\
\hline
\end{tabular}

A2, cumulative gas production between 3 and $20 \mathrm{~h}$ (for values see Table 2.1); GP72, cumulative gas production within $72 \mathrm{~h}$ (for values see Table 2.1); SEM standard error of mean.

Values of leaves with * are significantly different from values of the stems within cultivar $(P \leq 0.05)$. 


\section{CHAPTER 2}

The total DM and OM weight and the total volumes of A2 and GP72 of the leaves and the stems per plant of the 13 cultivars are shown in Table 2.2. Pauleen produced less leaves, while Grosso and Lg30218bm produced more leaves than the stems on a DM or OM basis. The total A2 (the product of A2 ( $\mathrm{ml} / \mathrm{g} \mathrm{OM})$ and the OM production $(\mathrm{g})$ per plant), indicating the total amount of cell walls of the leaves and the stems per plant that can be degraded in the rumen, was significantly greater for the leaves than for the stems of 5 cultivars. The total GP72 (the product of GP72 (ml/g OM) and the OM production $(\mathrm{g})$ per plant) which represented the total OM that can be degraded in the rumen of the leaves of 3 cultivars that greater than that of the stems.

Regression equations, which describe the relationships between the chemical composition and the in vitro gas production parameters of the leaves and the stems are shown in Tables 2.3 and 2.4, respectively. The A2 of the leaves was significantly, positively related to the hemicellulose content, and negatively related to the ADL and CP content, whereas the GP72 of the leaves was negatively affected by the ADL content. The B2 of the leaves was positively related with cellulose and ADL content and negatively related with $\mathrm{CP}$ and rest fraction content of the leaves. By using stepwise selection, both the ADL and CP content were selected to predict A2 and GP72 of the leaves, whereas the rest fraction and ADL content were selected to predict B2 of the leaves. Significant correlations were observed between the ADL (negative relationship) and the CP (positive relationship) content and A2 of the stems. The GP72 of the stems was negatively related with the cellulose and ADL content and positively related with the rest fraction. There were significant positive relationships between the hemicellulose and the cellulose content and B2 of the stems and a negative relationship between the rest fraction and B2 of stems. Stepwise regression indicated that A2 of the stems was best predicted by inclusion of the hemicellulose (positive relationship) and the cellulose and ADL (negative relationship) content. The optimal prediction of GP72 included the cellulose and ADL content (both negative relationship). Only cellulose content of the stems was selected to best predict the B2 of the stems.

\subsection{Discussion}

In general, the leaves of corn stover contained more ash and CP, but less ADL than the stems. In line with our results, Harika and Sharma (1994) and Mgheni et al., (2001) 
CHAPTER 2

Table 2.3 Relationships between in vitro gas production between 3 and $20 \mathrm{~h}$ incubation (parameter A2, ml/g OM) and within $72 \mathrm{~h}$ incubation (GP72, $\mathrm{ml} / \mathrm{g} \mathrm{OM}$ ) and chemical composition $(\mathrm{g} / \mathrm{kg} \mathrm{OM})$ of the leaves.

\begin{tabular}{llll}
\hline Regression equation & Adjusted $\mathrm{R}^{2}$ & $P$ & RMSE \\
\hline $\mathrm{A} 2=-21( \pm 66.5)+0.53( \pm 0.193) \times$ hemicellulose & 0.20 & 0.012 & 13.54 \\
$\mathrm{~A} 2=83( \pm 43.6)+0.20( \pm 0.115) \times$ cellulose & 0.08 & 0.090 & 14.58 \\
$\mathrm{~A} 2=188( \pm 12.2)-1.50( \pm 0.631) \times \mathrm{ADL}$ & 0.16 & 0.026 & 13.95 \\
$\mathrm{~A} 2=196( \pm 17.3)-0.49( \pm 0.229) \times \mathrm{CP}$ & 0.13 & 0.041 & 14.19 \\
$\mathrm{~A} 2=194( \pm 20.8)-0.19( \pm 0.112) \times$ rest fraction & 0.07 & 0.103 & 14.65 \\
A2 $2^{\dagger} 243( \pm 19.7)-1.89( \pm 0.545) \times$ ADL $-0.64( \pm 0.194)$ & 0.40 & 0.001 & 11.75 \\
$\times$ CP & & & \\
GP72 $=135( \pm 81.4)+0.40( \pm 0.237) \times$ hemicellulose & 0.07 & 0.102 & 16.58 \\
GP72 $=247( \pm 52.2)+0.07( \pm 0.137) \times$ cellulose & -0.03 & 0.609 & 17.46 \\
GP72 $=305( \pm 13.9)-1.66( \pm 0.719) \times$ ADL & 0.15 & 0.030 & 15.89 \\
GP72 $=309( \pm 20.1)-0.48( \pm 0.266) \times$ CP & 0.08 & 0.085 & 16.48 \\
GP72 $=279( \pm 25.0)-0.03( \pm 0.134) \times$ rest fraction & -0.04 & 0.834 & 17.54 \\
GP72 $=360( \pm 23.6)-2.05( \pm 0.654) \times$ ADL -0.64 & 0.33 & 0.004 & 14.10 \\
$( \pm 0.233) \times$ CP & & & \\
B2 $=3.4( \pm 2.569)+0.02( \pm 0.007) \times$ hemicellulose & 0.20 & 0.202 & 0.52 \\
B2 $=4.7( \pm 1.37)+0.01( \pm 0.004) \times$ cellulose & 0.38 & $<0.001$ & 0.46 \\
B2 $=8.9( \pm 0.44)+0.07( \pm 0.023) \times$ ADL & 0.26 & 0.004 & 0.50 \\
B2 $=12.1( \pm 0.62)-0.03( \pm 0.008) \times$ CP & 0.25 & 0.005 & 0.51 \\
B2 $=13.2( \pm 0.59)-0.02( \pm 0.003) \times$ rest fraction & 0.50 & $<0.001$ & 0.41 \\
B2 ${ }^{\dagger}=11.9( \pm 0.67)-0.01( \pm 0.003) \times$ rest fraction +0.05 & 0.63 & $<0.001$ & 0.35 \\
$( \pm 0.016) \times$ ADL & & & \\
\hline
\end{tabular}

A2, gas production between 3 and $20 \mathrm{~h}$; ADL, acid detergent lignin; B2, incubation time needed to reach half of A2; CP, crude protein; GP72, gas production within $72 \mathrm{~h}$; OM, organic matter; RMSE, root mean square error.

†ariables (chemical composition) were selected into the model by stepwise procedure with 0.05 as the significance level to enter or stay in the model. 


\section{CHAPTER 2}

Table 2.4 Relationships between in vitro gas production between 3 and $20 \mathrm{~h}$ incubation (parameter A2, ml/g OM) and within $72 \mathrm{~h}$ incubation (GP72, $\mathrm{ml} / \mathrm{g} \mathrm{OM}$ ) and chemical composition $(\mathrm{g} / \mathrm{kg} \mathrm{OM})$ of the stems.

\begin{tabular}{llll}
\hline Regression equation & Adjusted $\mathrm{R}^{2}$ & $P$ & RMSE \\
\hline A2 $=85( \pm 28.6)+0.14( \pm 0.101) \times$ hemicellulose & 0.07 & 0.188 & 19.13 \\
A2 $=146( \pm 27.2)-0.05( \pm 0.063) \times$ cellulose & -0.01 & 0.413 & 19.57 \\
A2 $=194( \pm 10.4)-1.77( \pm 0.256) \times$ ADL & 0.65 & $<0.001$ & 11.47 \\
A2 $=89( \pm 15.4)+1.79( \pm 0.768) \times$ CP & 0.15 & 0.029 & 17.93 \\
A2 $=121( \pm 10.0)+0.01( \pm 0.039) \times$ rest fraction & -0.04 & 0.789 & 19.82 \\
A2 $2^{\dagger} 142( \pm 13.5)+0.34( \pm 0.077) \times$ hemicellulose -0.12 & 0.82 & $<0.001$ & 8.18 \\
$( \pm 0.052) \times$ cellulose $-1.61( \pm 0.219) \times$ ADL & & & \\
GP72 $=332( \pm 43.3)-0.26( \pm 0.152) \times$ hemicellulose & 0.07 & 0.095 & 28.95 \\
GP72 $=403( \pm 30.4)-0.34( \pm 0.071) \times$ cellulose & 0.47 & $<0.001$ & 21.91 \\
GP72 $=369( \pm 15.6)-2.79( \pm 0.381) \times$ ADL & 0.68 & $<0.001$ & 17.09 \\
GP72 $=260( \pm 26.3)-0.12( \pm 1.316) \times$ CP & -0.04 & 0.927 & 30.71 \\
GP72 $=214( \pm 12.0)+0.19( \pm 0.047) \times$ rest fraction & 0.37 & $<0.001$ & 23.80 \\
GP72 ${ }^{\dagger}=432( \pm 18.2)-0.20( \pm 0.046) \times$ cellulose -2.18 & 0.82 & $<0.001$ & 12.76 \\
$( \pm 0.315) \times$ ADL & & & \\
B2 $=5.2( \pm 0.96)+0.01( \pm 0.003) \times$ hemicellulose & 0.33 & 0.001 & 0.64 \\
B2 $2^{\dagger} \neq=4.0( \pm 0.55)+0.03( \pm 0.001) \times$ cellulose & 0.74 & $<0.001$ & 0.39 \\
B2 $=7.5( \pm 0.69)+0.03( \pm 0.017) \times$ ADL & 0.07 & 0.106 & 0.75 \\
B2 $=7.6( \pm 0.65)+0.05( \pm 0.032) \times$ CP & 0.07 & 0.109 & 0.75 \\
B2 $=10.1( \pm 0.24)-0.01( \pm 0.001) \times$ rest fraction & 0.63 & $<0.001$ & 0.47 \\
\hline
\end{tabular}

A2, gas production between 3 and $20 \mathrm{~h}$; ADL, acid detergent lignin; B2, incubation time needed to reach half of A2; CP, crude protein; GP72, gas production within $72 \mathrm{~h}$; OM, organic matter; RMSE, root mean square error.

†Variables (chemical composition) were selected into the model by stepwise procedure with 0.05 as the significance level to enter or stay in the model.

Cellulose was the only variable that was selected into the model by stepwise procedure with 0.05 as the significance level to enter or stay in the model. 
reported that the ash content in the leaves was greater than in the stems (4 cultivars in total). It was also shown that both the leaf blade and the leaf sheath contained more ash than the stem (Tang et al., 2006, 2008, 2009). This observation can be ascribed to plant transpiration, which leads to a substantial evaporation of water and causes the deposition of minerals in the leaves (Li et al., 2014). Mgheni et al. (2001) also reported that the leaves contained more $\mathrm{CP}$ than the stems. The reason for this phenomenon may be that various enzymes are involved in photosynthesis occurring in the leaf, which contributes to a greater CP content in the leaves than in the stems. In a previous study (Verbic et al., 1995), the ADL content was greater in the stems than the leaves. In our study, we also found that stems have greater ADL content than leaves, although a significant interaction between cultivar and morphological fraction indicated that the actual difference between stems and leaves depends on cultivar. In our study, the ADF content in the leaves was lower than that in the stems of 8 cultivars and did not differ for 5 cultivars. For NDF content, there was even more variation in difference between leaves and stems, with NDF being greater in leaves of 7 cultivars, lower in leaves of 2 cultivars, and did not differ with NDF content of stems of 4 cultivars. Such differences in NDF content between stems and leaves being dependent on cultivar are consistent with Verbic et al. (1995).

The in vitro gas production technique was used to evaluate the degradability of the leaves and the stems. Cone et al. (1997) showed that A2 corresponds to the gas production caused by the fermentation of the non-soluble carbohydrates, and A2 is assumed to represent the cell wall degradation when the substrate is a forage with no starch. For most corn cultivars, the cell wall degradation of the leaves was greater than that of the stems. Besides, parameter B2 that represents the rate of cell wall degradation, was greater for leaves than for stems in 11 of the 13 cultivars. Considering the beneficial effects of feeding forages with a greater cell wall degradation to dairy cows on DM intake and milk production (Oba and Allen, 1999a, b; Kendall et al., 2009), it can be speculated that dairy cows will perform better when the leaves with a greater cell wall degradation are the main forage in the rations, compared with the stems having a lower cell wall degradation.

On average, the total DM weight of the leaves and the stems per plant was 43.1 and $42.9 \mathrm{~g}$, respectively, and the total OM weight of the leaves and the stems per plant was 39.5 and $40.8 \mathrm{~g}$, respectively. The results from our study provide a reference for farmers 


\section{CHAPTER 2}

to select the most suitable leaves and stems for their cattle based on the biomass yield and the cell wall degradation. For high producing dairy cows, the forage with the highest cell wall degradation may be the best choice because a greater cell wall degradation is associated with a greater DM intake and milk yield (Oba and Allen, 1999b). When milk production is low, and requirements for nutrients to sustain these production levels are low, the total biomass production of the leaves and the stems may become the first consideration in view of the lower feed intake level of low producing cows. Assuming the plant density of all the corn cultivars is the same, the cultivars with greater biomass production will alleviate the need of the forages by low producing animals. Economic models should be developed and used to evaluate whether it is profitable to separate the leaves and the stems considering both the cell wall degradation and biomass production.

In our study, the cell wall degradation of the leaves and the stems varied among the cultivars, which necessitates the development of regression equations to predict the cell wall degradation based on chemical composition, since the in vitro gas production cannot be implemented in each laboratory. The regression equations, therefore, were developed to predict the cell wall degradability, OM degradability, and the rate of cell wall degradation of the leaves and stems. The ADL content of both the leaves and the stems was found to be negatively correlated with A2 and GP72. These relationships were stronger for stems (adjusted $\mathrm{R}^{2} 0.65$ to 0.68 ) than for leaves (adjusted $\mathrm{R}^{2} 0.15$ to 0.16). The weaker relationship for leaves than for stems may be ascribed to the direct or indirect linkages between lignin and cellulose and hemicellulose (Susmel and Stefanon, 1993; Jeffries, 1994; Jalc, 2002; Vanholme et al., 2010; Ding et al.,2012). This observation was consistent with previous studies (Boon et al., 2005; Arora and Sharma, 2009; Tuyen et al., 2012; He et al., 2018). The CP content of the leaves was negatively correlated with both A2 and GP72 (tendency only) which is in line with Cone and Van Gelder (1999) who showed that the gas production was negatively correlated with the protein content in the substrate. During protein fermentation, ammonia is produced which binds with $\mathrm{H}^{+}$in the buffer solutions and as a result decreases $\mathrm{CO}_{2}$ released from the buffer. Nevertheless, $\mathrm{A} 2$ of the stems was positively correlated with CP content and GP72 of the stems was not influenced by the CP content, which may be partly attributed to the low CP content and low variation in CP content in the stems. The hemicellulose content was found to be positively correlated with the 
A2 of the stems in the optimal regression equation. The positive relationship between A2 and CP content of the stem, therefore, is also probably explained by the positive correlation $(\mathrm{r}=0.62)$ between $\mathrm{CP}$ and hemicellulose content. The negative correlation between cellulose and A2 of the stems may result from the fact that the cellulose content is related with the ADL content $(r=0.43)$ or that more cellulose is linked with lignin in the stems. In the optimal regression equations, the B2 of the leaves, representing rate of cell wall degradation, was positively related to $\mathrm{ADL}$ and rest fraction content; for stems, the optimal regression equation to predict B2 included cellulose only. Even though the rest fraction was not selected by the stepwise procedure to predict the B2 of the stems, the rest fraction still explained a large part of the variation of the B2 of the stems (adjusted $\mathrm{R}^{2}=0.63$ ). The positive correlations between the fiber fractions and the $\mathrm{B} 2$ of the leaves and stems and the negative correlation between the rest fraction and the $\mathrm{B} 2$ of the leaves and stems indicate that the rest fraction is more easily degraded than the fiber in the leaves and stems. Based on the results of the 13 corn cultivars evaluated, the A2 and GP72 of the stems can be more accurately predicted by chemical composition (adjusted $\mathrm{R}^{2}$ being 0.82 ) than that of the leaves (adjusted $\mathrm{R}^{2}$ between 0.33 and 0.40 ); for $\mathrm{B} 2$ the difference between stems and leaves in predictive capability was smaller (stems, adjusted $\mathrm{R}^{2}=0.74$; leaves, adjusted $\mathrm{R}^{2}=0.63$ )

\subsection{Conclusion}

The leaves of corn stover contained a greater CP content and lower ADL:pRDF than the stems. For most cultivars investigated, the A2 of the leaves, representing cell wall degradability, and the B2 of leaves, representing rate of cell wall degradation, was greater than that of the stems. Both A2 and GP72 of the stems were highly correlated with its chemical composition. For the leaves, A2 and GP72 only showed moderate relationships with the chemical composition.

\subsection{Acknowledgements}

We thank the Sino-Dutch Dairy Development Centre for their financial support and Limagrain (Limagrain Nederland BV) for providing the corn plants. Lei Mao, Mandy Bao, Taolin Yuan, and Haibo Lu (Wageningen University \& Research) are 


\section{CHAPTER 2}

acknowledged for their help during harvesting and splitting the corn plants.

\subsection{References}

Arora, D.S., Sharma, R.K., 2009. Enhancement in in vitro digestibility of wheat straw obtained from different geographical regions during solid state fermentation by white rot fungi. BioResources, 4, 909-920.

Boon, E.J.M.C., Engels, F., Struik, P.C., Cone, J.W., 2005. Stem characteristics of two forage maize (Zea mays L.) cultivars varying in whole plant digestibility. II. Relation between in vitro rumen fermentation characteristics and anatomical and chemical features within a single internode. NJAS-Wageningen J. Life Sci. 53, 87-109.

Cone, J.W., Van Gelder, A.H., Visscher, G.J.W., Oudshoorn, L., 1996. Influence of rumen fluid and substrate concentration on fermentation kinetics measured with a fully automated time related gas production apparatus. Anim. Feed Sci. Technol. 61, 113128.

Cone, J.W., Van Gelder, A.H., Driehuis, F., 1997. Description of gas production profiles with a three-phasic model. Anim. Feed Sci. Technol. 66, 31-45.

Cone, J.W., Van Gelder, A.H., 1999. Influence of protein fermentation on gas production profiles. Anim. Feed Sci. Technol. 76, 251-264.

Ding, S.Y., Liu, Y.S., Zeng, Y.N., Himmel, M.E., Baker, J.O., Bayer, E.A., 2012. How does plant cell wall nanoscale architecture correlate with enzymatic digestibility? Science, 338, 1055-1060.

Getachew, G., Robinson, P.H., DePeters, E.J., Taylor, S.J., 2004. Relationships between chemical composition, dry matter degradation and in vitro gas production of several ruminant feeds. Anim. Feed Sci. Technol. 111, 57-71.

Groot, J.C.J., Cone, J.W., Williams, B.A., Debersaques, F.M.A., Lantinga, E.A., 1996. Multiphasic analysis of gas production kinetics for in vitro fermentation of ruminant feeds. Anim. Feed Sci. Technol. 64, 77-89.

Harika, A.S., Sharma, D.D., 1994. Quality and yield differences in maize stover due to varieties and stage of harvesting. In: Joshi, A.L., Doyle, P.T., Oosting, S.J. (Eds.), 
Variation in quantity and quality of fibrous crop residues. ICAR, New Delhi and Wageningen Agricultural University, Wageningen, the Netherlands, pp. 20-28.

He Y., Mouthier, T.M.B., Kabel, M.A., Dijkstra, J., Hendriks, W.H., Struik, P.C., Cone, J.W., 2018. Lignin composition is more important than content for maize stem cell wall degradation. J. Sci. Food Agric. 98, 384-390.

Jalc, D., 2002. Straw enrichment for fodder production by fungi. In: Kempken, F. (Ed.), The Mycota XI, Agricultural Application. Berlin, Germany, pp. 19-38.

Jeffries, T.W.,1994. Biodegradation of lignin and hemicelluloses. In: Ratledge, C. (Ed.), Biochemistry of microbial degradation. Kluwer, Dordrecht, pp. 233-277.

Kendall, C., Leonard, C., Hoffman, P.C., Combs, D.K., 2009. Intake and milk production of cows fed diets that differed in dietary neutral detergent fiber and neutral detergent fiber digestibility. J. Dairy Sci. 92, 313-323.

Li, H.Y., Xu, L., Liu, W.J., Fang, M.Q., Wang, N., 2014. Assessment of the nutritive value of whole corn stover and its morphological fractions. Asian-Australas. J. Anim. Sci. 27, 194-200.

Lv, K.Y., Qin, H.G., Bai, J.F., Xu, Z G., 2013. Development of direct return of corn stalk to soil: Current status, driving forces and constrains. China Popul. Resour. Environ. 23, 171-176.

Mgheni, D.M., Ndemanisho, E.E., Hvelplund, T., Weisbjerg, M.R., 2001. Evaluation of the feeding value of two tropical cereal straws, maize stover, rice straw and their botanical fractions by nylon and mobile bag technique. Afr. J. Sci. Technol. 2, 65-71.

Oba, M., Allen, M.S., 1999a. Effects of brown midrib 3 mutation in corn silage on dry matter intake and productivity of high yielding dairy cows. J. Dairy Sci. 82, 135-142.

Oba, M., Allen, M.S., 1999b. Evaluation of importance of digestibility of neutral detergent fiber from forage: effects on dry matter intake and milk yield of dairy cows. J. Dairy Sci. 82, 589-596.

Susmel, P., Stefanon, B., 1993. Aspects of lignin degradation by rumen microorganisms. J. Biotechnol. 30, 141-148.

Tang, S., Tan, Z., Zhou, C., Jiang, H., Jiang, Y., Sheng, L., 2006. A comparison of in 


\section{CHAPTER 2}

vitro fermentation characteristics of different botanical fractions of mature maize stover. J. Anim. Feed Sci. 15, 505-515.

Tang, S.X., Gan, J., Sheng, L.X., Tan, Z.L., Tayo, G.O., Sun, Z.H., Wang, M., Ren, G.P., 2008. Morphological fractions, chemical composition and in vitro fermentation characteristics of maize stover of five genotypes. Anim. 2, 1772-1779.

Tang, S.X., Sheng, L.X., Tan, Z.L., Tayo, G.O., Liao, H.Y., Sun, Z.H., Zeng, B., Han, X.F., Zhou, C.S., Ren, G.P., 2009. Morphological fractions and in vitro fermentation characteristics of five endosperm types maize stover harvested at two maturity stages. J. Anim. Feed Sci. 18, 582-598.

Theander, O., Westerlund, E., 1993. Quantitative analysis of cell wall components. In: Jung, H.G., Buxton, D.B., Hatfield, R.D., Ralph, J. (Eds.), Forage Cell Wall Structure and Digestibility. Madison, WI: American Society of Agronomy, pp. 83-104.

Tolera, A., Berg, T., Sundstol, F., 1999. The effect of variety on maize grain and crop residue yield and nutritive value of the stover. Anim. Feed Sci. Technol. 79, 165-177.

Tolera, A., Sundstol, F., 1999. Morphological fractions of maize stover harvested at different stages of grain maturity and nutritive value of different fractions of the stover. Anim. Feed Sci. Technol. 81, 1-16.

Tuyen, V.D., Cone, J.W., Baars, J.J.P., Sonnenberg, A.S.M., Hendriks, W.H., 2012. Fungal strain and incubation period affect chemical composition and nutrient availability of wheat straw for rumen fermentation. Bioresour. Technol. 111, 336-342. Van Gelder, A.H., Hetta, M., Rodrigues, M.A.M., De Boever, J.L., Den Hartigh, H., Rymer, C., Van Oostrum, M., Van Kaathoven, R., Cone, J.W., 2005. Ranking of in vitro fermentability of 20 feedstuffs with an automated gas production technique: Results of a ring test. Anim. Feed Sci. Technol. 123-124, 243-253.

Vanholme, R., Demedts, B., Morreel, K., Ralph, J., Boerjan, W., 2010. Lignin biosynthesis and structure. Plant Physiol. 153, 895-905.

Van Soest, P.J., McQueen, R., 1973. The chemistry and estimation of fibre. Proc. Nutr. Soc. $32,123-130$.

Van Soest, P.J., Robertson, J., Lewis, B.A., 1991. Methods for dietary fiber, neutral detergent fiber, and nonstarch polysaccharides in relation to animal nutrition. J. Dairy 
CHAPTER 2

Sci. 74, 3583-3597.

Verbic, J., Stekar, J.M.A., Resnik-Cepon, M., 1995. Rumen degradation characteristics and fibre composition of various morphological parts of different maize hybrids and possible consequences for breeding. Anim. Feed Sci. Technol. 54, 133-148.

Warner, D., Dijkstra, J., Hendriks, W.H., Pellikaan, W.F., 2013. Passage kinetics of ${ }^{13} \mathrm{C}$-labeled corn silage components through the gastrointestinal tract of dairy cows. J. Dairy Sci. 96, 5844-5858. 


\section{Chapter 3}

\section{Lignin composition is more important than content for corn stem cell wall degradation}

Yuan $\mathrm{He}^{\mathrm{a}}$, Thibaut M.B. Mouthier ${ }^{\mathrm{b}}$, Mirjam A. Kabel ${ }^{\mathrm{b}}$, Jan Dijkstra ${ }^{\mathrm{a}}$, Wouter H. Hendriks ${ }^{\mathrm{a}}$, Paul C. Struik ${ }^{\mathrm{c}}$, John W. Cone ${ }^{\mathrm{a}}$

${ }^{a}$ Animal Nutrition Group, Wageningen University \& Research, PO Box 338, $6700 \mathrm{AH}$ Wageningen, the Netherlands

${ }^{\text {b} F o o d ~ C h e m i s t r y, ~ W a g e n i n g e n ~ U n i v e r s i t y ~ \& ~ R e s e a r c h, ~ P O ~ B o x ~ 17, ~} 6700$ AA Wageningen, the Netherlands

${ }^{\mathrm{c} C e n t r e}$ for Crop Systems Analysis, Wageningen University \& Research, PO Box 430, 6700 AK Wageningen, the Netherlands

Published in Journal of the Science of Food and Agriculture 2018, 98, 383-390. 


\section{CHAPTER 3}

\section{Abstract}

The relationship between the chemical and molecular properties, in particular the (acid detergent) lignin (ADL) content and composition expressed as the ratio between syringyl and guaiacyl compounds (S:G ratio), of corn stems and in vitro gas production was studied in order to determine which is more important in the degradability of corn stem cell walls in the rumen of ruminants. Different internodes from two contrasting corn cultivars (Ambrosini and Aastar) were harvested during the growing season.

The ADL content decreased with greater internode number within the stem, whereas the ADL content fluctuated during the season for both cultivars. The S:G ratio was lower in younger tissue (greater internode number or earlier harvest date) in both cultivars. For the gas produced between 3 and $20 \mathrm{~h}$, representing the fermentation of cell walls in rumen fluid, a stronger correlation $\left(R^{2}=0.80\right)$ was found with the $S: G$ ratio than with the ADL content $\left(\mathrm{R}^{2}=0.68\right)$. The relationship between ADL content or $\mathrm{S}: \mathrm{G}$ ratio and $72-\mathrm{h}$ gas production, representing total organic matter degradation, was weaker than that with gas produced between 3 and $20 \mathrm{~h}$.

The S:G ratio plays a more dominant role than ADL content in corn stem cell wall degradation.

Keywords: lignin content, lignin composition, cell wall degradation, corn stem, gas production, in vitro fermentation 


\section{CHAPTER 3}

\subsection{Introduction}

Forage corn is an important forage for high-yielding dairy cows in most areas of the world. A large part of the metabolizable energy in forage corn is derived from starch in the kernel. The fiber-rich remainder of the plant (the stover) also contains a significant amount of metabolizable energy and nutrients, despite its lower degradability. However, research over the past decades has mainly focused on improving yield and proportion of starch in forage corn in order to obtain a greater nutritional value and accommodate more to the nutritional needs of cattle. ${ }^{1}$ This focus did not lead to greater and/or more rapid degradation of the non-starch fraction of the plant (mainly cell walls) (Jung et al., 2012). Research into the causes of differences in degradability of the cell walls may result in better and faster degradability of cell walls of corn stems. Increased cell wall degradation of forage corn by harvesting at earlier stages of maturity will decrease starch content and increase enteric methane production (Hatew et al., 2016). However, forage corn with a greater cell wall degradation at a similar growth stage will have a greater nutritional value, so lower costs, lower environmental emissions and a better performance of the animals.

The nutritive value of corn stover can vary widely and be affected by genotype, climate, maturity of the plant, and so on (Boon et al., 2008). The relationship between the degradability of corn stem cell walls and the different properties of the plant is well documented. For example, there is a strong negative correlation between cell wall maturation and degradability, which generally is ascribed to the increasing amount of acid detergent lignin (ADL) compared with other cell wall compounds (Goto et al., 1991). However, ADL content cannot fully explain the variation in cell wall degradability, with evidence that the ADL content may differ between cultivars without differences in cell wall degradability (Cone and Engels, 1993).

Lignin is an organic polymer made up of phenyl propane units organized in a threedimensional structure. The precursors of these building blocks are coniferyl, sinapyl and $p$-coumaryl alcohols, which can be transformed into guaiacyl (G unit), syringyl (S unit) and $p$-hydroxyphenyl (H unit) units respectively through a complex dehydrogenative polymerization process (Morrison et al., 1998). Lignin content and composition change during plant maturation when more lignified primary and secondary cell walls of sclerenchyma and vascular tissues are developed (Grabber, 


\section{CHAPTER 3}

2005). Studies on forages of different physiological maturation indicate a shift towards a more S unit-type lignin with advancing maturity in some species (Buxton and Russell, 1988; Himmelsbach et al., 1983; Joseleau et al., 1976). As already mentioned, maturation with an increasing content of ADL reduces forage degradability. In view of the complexity of factors involved in cell wall development, insufficient information exists on which factors (ADL content or composition) precisely determine the degradability of corn stem cell walls.

The present study focused on the relationship between the chemical and molecular properties of corn stem cell walls and in vitro rumen fermentation, measured by an automated gas production technique. The goal is to provide further insights into the background of differences in the composition of cell walls among different samples, at a chemical and molecular level, and the relationship with degradability.

\subsection{Materials and Methods}

\subsubsection{Corn production and management}

Seeds of the corn cultivars Ambrosini and Aastar (provide by Limagrain, Rilland, the Netherlands) were sown in the first week of May 2012 at the experimental fields of Unifarm in Wageningen, the Netherlands. The plants' sowing density was 10 plants $/ \mathrm{m}^{2}$, with $13.3 \mathrm{~cm}$ between plants and $75 \mathrm{~cm}$ between the rows. The fields had a sandy soil with $\mathrm{pH} 5.5,21 \mathrm{~g} / \mathrm{kg}$ organic matter $(\mathrm{OM})$ and adequate levels of macro- and micronutrients. The fields were fertilized with $40 \mathrm{~kg} / \mathrm{ha}$ of cow manure, $150 \mathrm{~kg} / \mathrm{ha}$ of calcium ammonium nitrate (CAN, $270 \mathrm{~g} / \mathrm{kg} \mathrm{N}), 160 \mathrm{~kg} / \mathrm{ha}$ of potassium $(\mathrm{K} 60,600 \mathrm{~g} / \mathrm{kg}$ $\mathrm{K}_{2} \mathrm{O}$ ) and $100 \mathrm{~kg} /$ ha phosphate (triple superphosphate, $450 \mathrm{~g} / \mathrm{kg} \mathrm{P}_{2} \mathrm{O}_{5}$ ).

\subsubsection{Sample preparation}

During 2012, the internodes were harvested excluding the lower and upper nodes. Only internode 7 (counted from the ground) was harvested on 28 and 14 days before anthesis (d -28 and d -14, respectively) and on 14, 28, 42 and 70 days after anthesis (d 14, d 28, d 42 and $\mathrm{d} 70$ respectively). As the major changes occurred after anthesis and levelled off afterwards, the interval between the last two sampling dates was 4 weeks instead of 


\section{CHAPTER 3}

2 weeks. At anthesis (14 August), whole plants were harvested and internode 5, 7, 9, 11, 13 and 15 were collected. In all cases, internodes were collected from 12 plants (four plots, three plants per plot) and randomly separated to be duplicated. All the internodes were stored at $-20{ }^{\circ} \mathrm{C}$ directly after harvesting.

All the internodes were oven-dried at $70^{\circ} \mathrm{C}$ and ground to pass a $1 \mathrm{~mm}$ sieve using a Peppink 100 AN cross-beater mill (Peppink, Deventer, The Netherlands) before chemical analysis, pyrolysis gas chromatography-mass spectrometry (Py-GC-MS) analysis, and in vitro fermentation.

\subsubsection{Chemical analysis}

Dry matter (DM) was determined gravimetrically after $4 \mathrm{~h}$ at $103{ }^{\circ} \mathrm{C}$, and ash after $3 \mathrm{~h}$ at $550{ }^{\circ} \mathrm{C}$. Neutral detergent fiber (NDF) was determined by the method of Van Soest et al. (1991), using a heat-resistant amylase and expressed exclusive of residual ash. Acid detergent fiber (ADF) and ADL were determined by the method of Van Soest and McQueen (1973) and also expressed exclusive of residual ash. The difference between $\mathrm{NDF}$ and ADL was defined as potentially rumen degradable fiber (pRDF). Nitrogen (N) was determined by the Kjeldahl method, and crude protein $(\mathrm{CP})$ was calculated as $\mathrm{N} \times$ 6.25 .

\subsubsection{Pyrolysis gas chromatography-mass spectrometry analysis}

Pyrolysis of $100 \mu \mathrm{g}$, weighed on a Mettler-Toledo XP6 microbalance (Mettler-Toledo, Columbus, USA) was performed with an EGA/PY-3030D micro-furnace pyrolyzer (Frontier Laboratories, Fukushima, Japan) connected to a Thermo7820A gas chromatograph using a DB-1701 fused-silica capillary column $(60 \mathrm{~m} \times 0.25 \mathrm{~mm}$ internal diam eter, $0.25 \mu \mathrm{m}$ film thickness) coupled to a DSEI thermo mass-selective detector (electron impact at $70 \mathrm{eV}$ ) (Thermo Scientific, Waltham, MA, USA). The pyrolysis was performed at $500{ }^{\circ} \mathrm{C}$. The oven temperature was programmed from $45^{\circ} \mathrm{C}$ (0-4 min) to $280{ }^{\circ} \mathrm{C}(5-60 \mathrm{~min})$ at $4{ }^{\circ} \mathrm{C} / \mathrm{min}$. Helium was the carrier gas $(1 \mathrm{~mL} / \mathrm{min})$. Species coming from lignin units and species coming from $p$-coumaric and ferulic acids were distinguished assuming more than $80-85 \%$ of $p$-coumaric and ferulic acids was considered part of lignin and not xylan, also based on the ratios of esterified $p$-coumaric 


\section{CHAPTER 3}

and ferulic acids to xylan reported by Van Dongen et al. (2011). The compounds were identified by comparing their mass spectra with those of the Wiley and NIST libraries and with those reported in literature (Ralph and Hatfield, 1991). The relative abundance of each identified compound was calculated based on the total relative area obtained from the pyrogram according to Jurak et al. (2015). All the compounds identified and their spectra were checked manually. As the method is time consuming, not all samples were analyzed, but enough to see differences and trends. One sample from the duplicated samples of internode 5, 9, 13 and 15 of both corn cultivars harvested at anthesis, and one sample from duplicated samples of internode 7 of both corn cultivars harvested on d -28, d 0, d 28 and d 70 were analyzed using Py-GC-MS. The syringyl:guaiacyl $(\mathrm{S}: \mathrm{G})$ ratio was calculated by dividing the sum of the abundance of the syringyl compounds divided by the sum of the abundance of the guaiacyl compounds.

\subsubsection{In vitro gas production}

The fermentation kinetics were determined with the in vitro gas production technique (Cone et al., 1996). Incubation of $0.5 \mathrm{~g}$ of OM was performed in $60 \mathrm{~mL}$ buffered rumen fluid (one part of rumen fluid and two parts of buffer) in $250 \mathrm{~mL}$ bottles at $39^{\circ} \mathrm{C}$ in a shaking water bath. Each sample was run in one bottle each time and each sample was run twice. Gas production was recorded for $72 \mathrm{~h}$ with an automated system (Cone et al., 1996). Results were corrected for blank gas productions; that is, buffered rumen fluid but without a substrate.

Rumen fluid was obtained from two non-lactating cows that were fed twice a day with hay, and with $1 \mathrm{~kg}$ of concentrate in the morning. Rumen fluid was collected $2 \mathrm{~h}$ after the morning feeding and was pooled, stored in a warm insulated flask filled with $\mathrm{CO}_{2}$, filtered through cheesecloth, and mixed with an anaerobic buffer/mineral solution as described by Cone et al. (1996). All processing of rumen fluid took place under continuous flushing with $\mathrm{CO}_{2}$.

The three-phasic mathematical model for gas production as described by Cone et al. (1996) and Groot et al. (1996) was used to determine OM and cell wall degradation. The gas production curves are divided into three different sub-curves, each with an asymptote (A), a half-time value (B) and a shape parameter (C) (Groot et al., 1996). 


\section{CHAPTER 3}

The asymptotes of sub-curve 1 (A1) correspond to the gas production between 0 and 3 $\mathrm{h}$ incubation and are caused by fermentation of the water-soluble components, and those of sub-curve 2 (A2) correspond to the gas production between 3 and $20 \mathrm{~h}$ incubation caused by fermentation of the non-soluble components (Cone et al., 1997). The halftime value $B$ is the incubation time (h) needed to reach half of the maximum gas production, representing a measure for the rate of degradation of the total OM.

\subsubsection{Statistical analysis}

Data were analyzed using the GLM procedure of SAS/STAT ${ }^{\circledR} 9.3$ (Statistical Analysis System, Cary, NC, USA) and the model included corn cultivar (Ambrosini and Aastar), maturity (different harvest dates or different internodes), and cultivar $\times$ maturity as fixed effects. Because Py-GC-MS analyses were performed on one sample of selected internodes and harvest dates only, no interaction effect was included in the model when analyzing S:G ratio data. Differences among main effects were analyzed using TukeyKramer's multiple comparison procedure in the LSMEANS statement of SAS. Significant effects were declared at $P \leq 0.05$ and trends at $0.05<P \leq 0.10$.

\subsection{Results}

\subsubsection{Chemical composition of internode 7 at different harvest dates}

The levels of ash, NDF, ADF, ADL, the ratio of lignin to pRDF (ADL:pRDF ratio) and the S:G ratio in internode 7, harvested at different dates during 2012, are shown in Table 3.1. Cultivar, harvest date and their interactions showed significant effects on the concentrations of ash, NDF, ADF and ADL and on the ADL:pRDF ratio. There was no clear trend for a greater level of $\mathrm{NDF}, \mathrm{ADF}$ and $\mathrm{ADL}$ in more mature tissue. The ADL:pRDF ratio increased to the highest value on d 28 in Ambrosini and d 14 in Aastar and then decreased in both cultivars. The concentrations of NDF, ADF, and ADL and ADL:pRDF ratio were greater in Ambrosini than in Aastar except for the internode harvested on d 14. Cultivar and harvest date also showed significant effects on the S:G ratio, with a greater S:G ratio observed in Ambrosini than in Aastar and the lowest value of the $\mathrm{S}: \mathrm{G}$ ratio observed in the youngest internode harvested on $\mathrm{d}-28$ for both cultivars. 


\section{CHAPTER 3}

\subsubsection{Chemical composition of several internodes harvested at anthesis}

The levels of ash, NDF, ADF, ADL, ADL:pRDF ratio and S:G ratio in successive internodes within the stem harvested at anthesis for the two cultivars are shown in Table 3.2. Cultivar and internode significantly affected all these parameters and a significant cultivar $\times$ internode effect for ash, NDF, ADF and ADL:pRDF ratio was found. Again, no clear trend for a greater level of NDF in both cultivars and ADF in Ambrosini in older internodes (lower internode number) was observed. However, there was a clear trend for a lower concentration of $\mathrm{ADL}$ and a lower $\mathrm{ADL}: \mathrm{pRDF}$ ratio and $\mathrm{S}: \mathrm{G}$ ratio in younger tissues (higher internodes) for both cultivars. Aastar had significantly lower concentrations of NDF, ADF and ADL and a lower ADL:pRDF ratio and S:G ratio than Ambrosini.

\subsubsection{In vitro fermentation of internode 7 at different harvest dates}

The results of the kinetics of gas production of internode 7 harvested at different dates of the year are shown in Table 3.1. Cultivar, harvest date and the interactions showed significant effects on A1, A2, total gas production after $72 \mathrm{~h}$ (GP72) and B. For A1, B and GP72 for both Ambrosini and Aastar, there was no clear increase or decrease at later harvest dates. The earliest harvested internodes had the highest A2, and there was a tendency for lower gas production as the internodes were harvested later.

\subsubsection{In vitro fermentation of several different internodes harvested at anthesis}

The results of the kinetics of gas production of internode 5, 7, 9, 11, 13 and 15 harvested on the same day for the two cultivars are shown in Table 3.2. Cultivar and internode showed significant effects on A1, A2, GP72 and B. The interactions between cultivar and internode only influenced A1 significantly. There was no clear trend for A1. A greater A2 was observed when the internode was younger (higher internode) in the plant for Aastar, while the lowest internode (internode 5) showed the lowest A2 and GP72 for both cultivars. The half-time value B tended to decrease from lower to higher internodes. 
CHAPTER 3

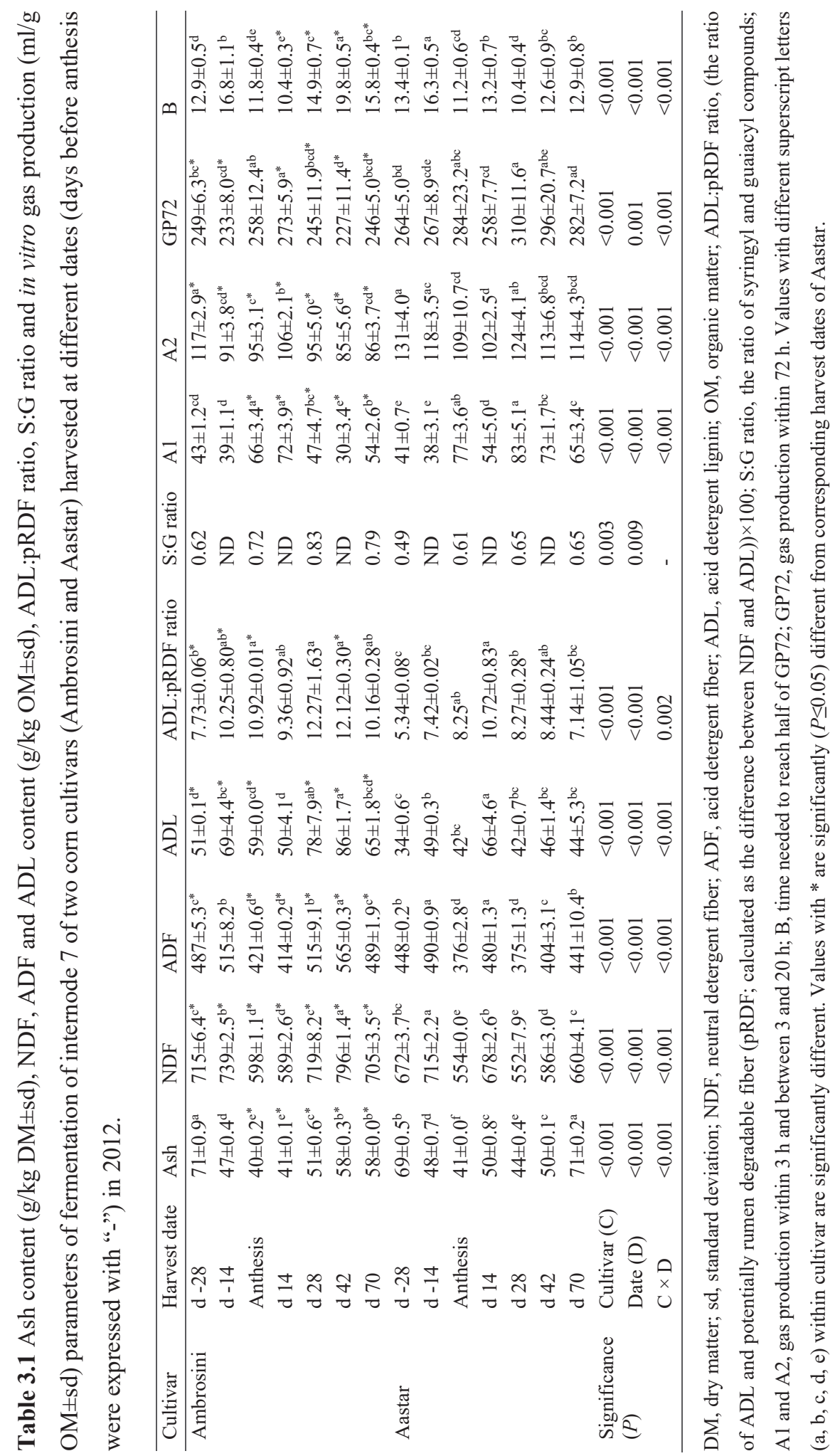


CHAPTER 3

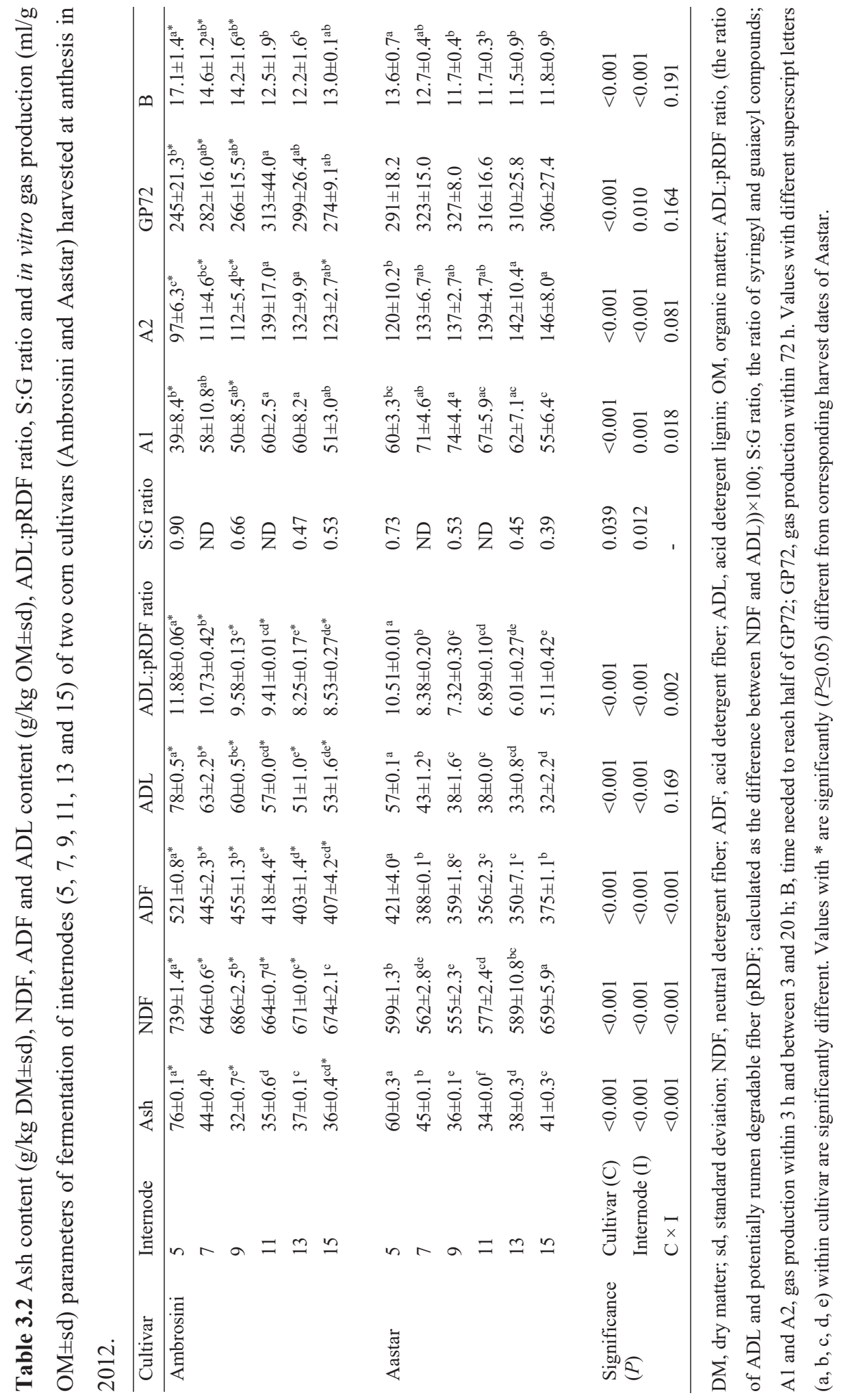


CHAPTER 3
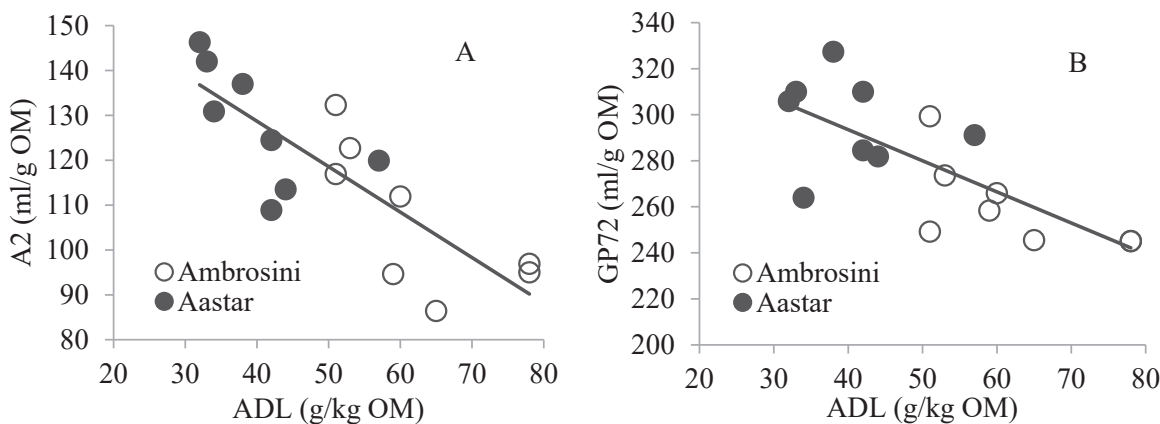

Figure 3.1 A: relationship between ADL content and in vitro gas production between 3 and $20 \mathrm{~h}$ incubation (parameter A2) of the internodes 5, 9, 13 and 15 harvested at anthesis and internode 7 harvested on 28 days before anthesis, at anthesis, and 28 and 70 days after anthesis from two corn cultivars (Ambrosini and Aastar): $\mathrm{A} 2=-1.01 \pm 0.19 \times \mathrm{ADL}+169 \pm 9.9,($ estimate $\pm \mathrm{SE})$, root mean square error $=10.54, \mathrm{R}^{2}=0.68$; B: relationship between ADL content and in vitro gas production within $72 \mathrm{~h}$ incubation (GP72) of the internodes 5, 9, 13 and 15 harvested at anthesis and internode 7 harvested on 28 days before anthesis, at anthesis, and 28 and 70 days after anthesis from two corn cultivars (Ambrosini and Aastar): GP72 $=-1.35$ $\pm 0.33 \times \mathrm{ADL}+348 \pm 17.6$, (estimate $\pm \mathrm{SE})$, root mean square error $=18.75, \mathrm{R}^{2}=0.54$.
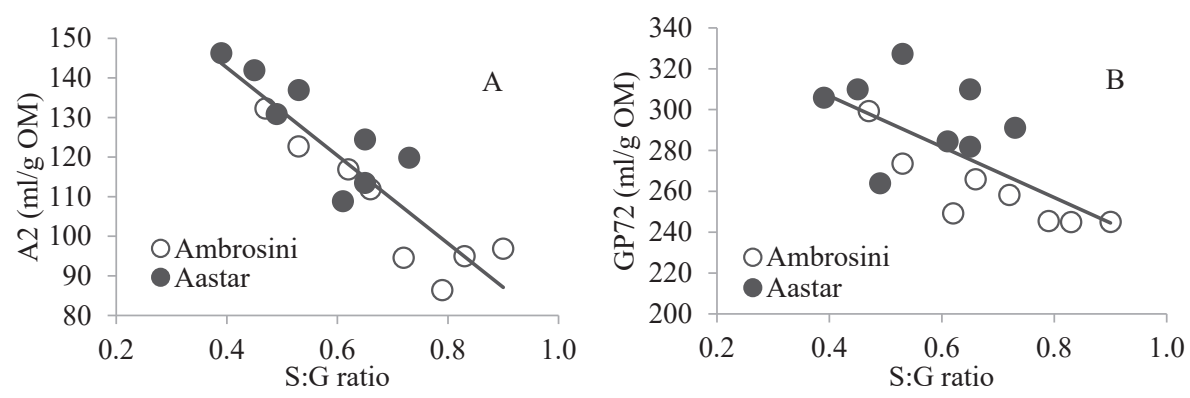

Figure 3.2 A: relationship between $\mathrm{S}: \mathrm{G}$ ratio and in vitro gas production between 3 and $20 \mathrm{~h}$ incubation (parameter A2) of the internodes 5, 9, 13 and 15 harvested at anthesis and internode 7 harvested on 28 days before anthesis, at anthesis, and 28 and 70 days after anthesis from two corn cultivars (Ambrosini and Aastar), $\mathrm{A} 2=-110.99 \pm 14.85 \times \mathrm{S}: \mathrm{G}$ ratio $+187 \pm 9.5$, (estimate $\pm \mathrm{SE})$, root mean square error $=8.32, \mathrm{R}^{2}=$ 0.80; B: relationship between $\mathrm{S}: \mathrm{G}$ ratio and in vitro gas production within $72 \mathrm{~h}$ incubation (GP72) of the internodes 5, 9, 13 and 15 harvested at anthesis and internode 7 harvested on 28 days before anthesis, at anthesis, and 28 and 70 days after anthesis from two corn cultivars (Ambrosini and Aastar), GP72 $=-124.27$ $\pm 36.67 \times \mathrm{S}: \mathrm{G}$ ratio $+356 \pm 23.5$, (estimate $\pm \mathrm{SE}$ ), root mean square error $=20.54, \mathrm{R}^{2}=0.45$. 


\section{CHAPTER 3}

\subsubsection{Relationship between ADL content or S:G ratio and in vitro fermentation}

The relationships between ADL content and A2 and GP72 are shown in Fig. 3.1. The relationship between ADL content and A2 (indicating cell wall degradation) was stronger $\left(\mathrm{R}^{2}=0.68\right)$ than the relationship between ADL content and GP72 (indicating OM degradation) $\left(\mathrm{R}^{2}=0.54\right)$.

The relationships between $\mathrm{S}: \mathrm{G}$ ratio and $\mathrm{A} 2$ and GP72 are shown in Fig. 3.2. The relationship between $S: G$ ratio and $A 2$ was stronger $\left(R^{2}=0.80\right)$ than the relationship between $\mathrm{S}: \mathrm{G}$ ratio and $\mathrm{GP72}\left(\mathrm{R}^{2}=0.45\right)$. Upon comparison with the relationships between ADL content and A2, the results indicate that the $\mathrm{S}: \mathrm{G}$ ratio plays a more dominant role in cell wall degradation than the ADL content; however, in comparison with ADL content, the S:G ratio appeared not to have a strong relationship with OM degradation.

\subsection{Discussion}

\subsubsection{Effect of maturity on chemical composition}

The developing internodes of corn stem provide the opportunity to study how cell wall composition changes during maturation (Morrison and Buxton, 1993; Morrison et al., 1994a, b). Different maturity stages can be represented by successive internodes of the corn stem harvested at the same time (Morrison and Buxton, 1993) or by selecting a given internode and harvesting it at different dates (Morrison et al., 1994b). Within the stem, cell walls of the upper part (greater internode number) are physiologically younger and less lignified than those of the lower part. In this study, internode 5, 7, 9, 11,13 and 15 sampled on the same day and internode 7 sampled on different days during the growth were used to investigate how maturity influenced the chemical composition of cell walls, as well as cell wall degradation.

Cone and Engels (1993) reported that NDF and ADF increased with increasing maturity, which was also demonstrated by Tolera and Sundstol (1999). However, NDF and ADF did not have the clear increasing trend with maturity in the present study, which is in line with the results reported by Boon et al. (2008) and Cone et al. (2008). In contrast with expected changes in the ADL content of the stems (Cone and Engels, 1993; Tolera and Sundstol, 1999), in this study the ADL content did not increase when harvest date 


\section{CHAPTER 3}

was used as an indicator of maturity. When different internodes sampled at anthesis were used to investigate the changes in the ADL content, the ADL content, as expected, increased from the upper internodes (internode 15, average $43 \mathrm{~g} / \mathrm{kg} \mathrm{OM}$ ) to the lower internodes (internode 5, average $68 \mathrm{~g} / \mathrm{kg} \mathrm{OM}$ ). The ADL:pRDF ratio, as an indication of potentially degradable OM, is expected to be greater in older internodes, which is demonstrated by different internodes harvested at the same date. However, when internode 7 was harvested at different days, an increasing ADL:pRDF ratio in early growth was observed followed by a trend to decrease in later growth.

The $\mathrm{S}: \mathrm{G}$ ratio increased during the maturation, especially from the top to the bottom of the stem. This observation is in line with data from other studies (Buxton and Russell, 1988; Chen et al., 2002; Morrison et al., 1998). Deposition of G units continues throughout the lignification of cell walls, while large amounts of S units are deposited mainly in the middle and late stages of lignification (Morrison et al., 1998; Terashima et al., 1993). Therefore, the composition of lignin shifts from lignin with primarily $\mathrm{G}$ units to lignin with mixed S-G units during cell wall development and the S:G ratio increases.

\subsubsection{Effect of maturity on cell wall degradation}

In this study, the in vitro gas production technique was used to assess the cell wall degradation. In the case of corn stems, cell wall degradability is represented by A2, being the gas production caused by fermentation of the non-soluble fraction, while OM degradability is represented by GP72 (the gas produced after $72 \mathrm{~h}$ fermentation) as indicated by Cone et al. $(1996,1997)$ and Groot et al. (1996).

The decline in cell wall degradability during maturation is well documented, and it is generally accepted that the formation of more lignified plant cell walls during maturation is the major reason leading to lower cell wall degradation (Jung and Deetz, 1993). Jung and Casler (2006) found that the degradability of cell walls in corn stems after both 24- and 96- $\mathrm{h}$ in vitro incubations with rumen fluid decreased as the stems were harvested later. Our results show that there was a clear trend that the cell wall degradability decreased only from the younger internode to the older internode within the stem. For internode 7, sampled at different dates, there was rapid drop in cell wall degradability up to August 14, to remain fairly constant afterwards, which is in line 


\section{CHAPTER 3}

with Cone and Engels (1993), who reported that the cell wall degradability decreased significantly up to 15 August and remained fairly constant afterwards when the date of sowing was 25 April, which is close to the date of sowing in our study.

\subsubsection{Factors related to cell wall degradability}

Lignin content of forages has long been reported to be negatively correlated with cell wall degradability (Johnson et al., 1962), and this relationship, which was also observed here, is consistent with previous studies (Boon et al., 2005; Casler and Jung, 2006; Jung and Lamb, 2003; Jung and Vogel, 1986; Jung et al., 1997). Boon et al. (2005) found that the lignin content in the internode 7 of corn stem was significantly correlated with cell wall degradation assessed by in vitro gas production. The negative correlation between lignin content and cell wall degradation was also reported in both grass (Casler and Jung, 2006; Jung and Vogel, 1986; Jung et al., 1997) and legumes (Jung and Lamb, 2003; Jung et al., 1997). Even though these studies demonstrated that lignin content is an important factor that limits cell wall degradation in ruminants, the strength of the relationship varied among studies due to the methods that were used to evaluate cell wall degradation. However, comparing different corn genotypes, Cone and Engels (1993) suggested that ADL content is not always a good indicator of degree of cell wall degradability, which is supported by Sommerfeldt et al. (1979), who observed that degradability of cell walls was greater for bm 3 corn than for a normal variety although no differences in ADL content were observed. However, both a reduced ADL content and a lower S:G ratio were found in bm3 corn in other studies (Gaudillere and Monties, 1989; Lam et al., 1996). The relationship between ADL content or ADL composition and cell wall degradability is not fully understood even though this relationship has been investigated for many years. Compared with the S:G ratio, the ADL content has a weaker relationship with cell wall degradability (Panel A, Fig. 1 and 2). This result is in accordance with what Vailhe et al. (1996) and Sewalt et al. (1997) observed for tobacco. Guo et al. (2001) found that a greater S:G ratio in alfalfa resulted in a greater cell wall digestibility, which is opposite to our results. The significant correlation between the $\mathrm{S}: \mathrm{G}$ ratio and the cell wall degradability in corn stems was not found by Jung and Buxton (1994) and Grabber et al. (1997). It should be noticed that only a single maturity stage was used in the research conducted by Jung and Buxton (1994) 


\section{CHAPTER 3}

and by Grabber et al. (1997), which may be the reason of the discrepancy between the results of these studies. When forages were harvested across maturity stages, strong negative correlations between ADL content and cell wall degradability were shown (Jung and Vogel, 1986; Van Soest, 1967), while only weak negative correlations existed between ADL content and cell wall degradability if forages of a single maturity stage were examined (Jung and Buxton, 1994; Jung and Vogel, 1992).

The reason why a lower $\mathrm{S}: \mathrm{G}$ ratio is related to greater degradability is difficult to explain. Jung and Deetz (1993) hypothesized that syringyl-rich lignin would be more inhibitory to cell wall degradation, as syringyl monolignols have fewer potential polymerization sites and should have a more linear polymer structure which could protect a larger area of the secondary cell walls from degradation than the more branched guaiacyl-rich lignin. However, Filley et al. (2002) emphasized that the G-type lignin is more resistant to chemical and biological breakdown than the S-type lignin. In all likelihood, the influence of the $\mathrm{S}: \mathrm{G}$ ratio on cell wall degradability should not be explained by the nature of the $\mathrm{S}$ or $\mathrm{G}$ unit itself in view of the complex linkages between $\mathrm{S}$ or $\mathrm{G}$ units with other molecular structures that may be related to a reduction in degradability. One possible explanation is that, during the formation of S units, mostly p-coumaric acid is connected with the $\mathrm{S}$ unit through ester bonds (Ralph et al., 1994) and $p$-coumaric acid is thought to be more toxic to ruminal microorganisms than other phenolic acids and may limit cell wall degradation (Akin, 1986). The latter is supported by Martínez et al. (2016) who reported that removal of $p$-coumarate in sugarcane bagasse enhanced the enzyme degradation of cellulose and led to a greater cell wall degradation.

\subsection{Conclusion}

The ADL content and the S:G ratio increased from the upper internode to the lower internode within the corn stem for both cultivars investigated (Aastar and Ambrosini) and the $\mathrm{S}: \mathrm{G}$ ratio in internode 7 tended to increase during the growing season. However, the ADL content in internode 7 fluctuated during maturation. Cell wall degradability, as determined with the gas production technique, tended to decrease up to anthesis with no clear pattern after anthesis, whereas cell wall degradability increased with internode number (from bottom to top). 


\section{CHAPTER 3}

For corn stems, the $\mathrm{S}: \mathrm{G}$ ratio (lignin composition) showed a better relationship with cell wall degradability than the ADL content. A lower S:G ratio was associated with a greater degradability.

\subsection{Acknowledgements}

We would like to thank Sino-Dutch Dairy Development Centre (SDDDC) for their financial support.

\subsection{References}

Akin, D.E., 1986. Interaction of ruminal bacteria and fungi with southern forages. J. Anim. Sci. 63, 962-977.

Boon, E.J.M.C., Engels, F.M., Struik, P.C., Cone, J.W., 2005. Stem characteristics of two forage maize (Zea mays L.) cultivars varying in whole plant digestibility. II. Relation between in vitro rumen fermentation characteristics and anatomical and chemical features within a single internode. Netherlands J. Agric. Sci.-Wageningen J. Life Sci. 53, 87-109.

Boon, E.J.M.C., Struik, P.C., Tamminga, S., Engels, F.M., Cone, J.W., 2008. Stem characteristics of two forage maize (Zea mays L.) cultivars varying in whole plant digestibility. III. Intra-stem variability in anatomy, chemical composition and in vitro rumen fermentation. Netherlands J. Agric. Sci.-Wageningen J. Life Sci. 56, 101-122.

Buxton, D.R., Russell, J.R., 1988. Lignin constituents and cell-wall digestibility of grass and legume stems. Crop Sci. 28, 553-558.

Casler, M.D., Jung, H.G., 2006. Relationships of fibre, lignin, and phenolics to in vitro fibre digestibility in three perennial grasses. Anim. Feed Sci. Technol. 125, 151-161.

Chen, L., Auh, C., Chen, F., Cheng, X.F., Aljoe, H., Dixon, R.A., Wang, Z.Y., 2002. Lignin deposition and associated changes in anatomy, enzyme activity, gene expression, and ruminal degradability in stems of tall fescue at different developmental stages. J. Agric. Food Chem. 50, 5558-5565.

Cone, J.W., Engels, F.M., 1993. The influence of ageing on cell wall composition and 
degradability of three maize genotypes. Anim. Feed Sci. Technol. 40, 331-342.

Cone, J.W., Van Gelder, A.H., Driehuis, F., 1997. Description of gas production profiles with a three-phasic model. Anim. Feed Sci. Technol. 66, 31-45.

Cone, J.W., Van Gelder, A.H., Van Schooten, H.A., Groten, J.A.M., 2008. Effects of forage maize type and maturity stage on in vitro rumen fermentation characteristics. Netherlands J. Agric. Sci.-Wageningen J. Life Sci. 55, 139-154.

Cone, J.W., Van Gelder, A.H., Visscher, G.J.W., Oudshoorn, L., 1996. Use of a new automated time related gas production apparatus to study the influence of substrate concentration and source of rumen fluid on fermentation kinetics. Anim. Feed Sci. Technol. 61, 113-128.

Filley, T.R., Cody, G.D., Goodell, H., Jellison, J., Noser, C., Ostrofsky, A., 2002. Lignin demethylation and polysaccharide decomposition in spruce sapwood degraded by brown-rot fungi. Org. Geochem. 33, 111-124.

Gaudillere, M., Monties, B., 1989. Biochemical and biosynthetic studies on lignification of Gramineae.In: Lewis, N.G., Paice, M.G. (Eds.), Plant Cell Wall Polymers: Biogenesis and Biodegradation. American Chemical Society, Washington, DC, pp. 182-192.

Goto, M., Gordon, A.H., Chesson, A.,1991. Changes in cell-wall composition and degradability of sorghum during growth and maturation. J. Sci. Food Agric. 54, 47-60.

Grabber, J.H., 2005. How do lignin composition, structure and cross-linking affect degradability? A review of cell wall model studies. Crop Sci. 45, 820-831.

Grabber, J.H., Ralph, J., Hatfield, R.D., Quideau, S., 1997. p-Hydroxyphenyl, guaiacyl, and syringyl lignins have similar inhibitory effects on wall degradability. J. Agric. Food Chem. 45, 2530-2532.

Groot, J.C.J., Cone, J.W., Williams, B.A., Debersaques, F.M.A., Lantinga, E.A., 1996. Multiphasic analysis of gas production kinetics for in vitro fermentation of ruminant feeds. Anim. Feed Sci. Technol. 64, 77-89.

Guo, D.G., Chen, F., Wheeler, J., Winder, J., Selman, S., Peterson, M., Dixon, R.A., 2001. Improvement of in-rumen digestibility of alfalfa forage by genetic manipulation of lignin $O$-methyltransferases. Transgenic. Res. 10, 457-464. 


\section{CHAPTER 3}

Hatew, B., Bannink, A., Van Laar, H., De Jonge, L.H., Dijkstra, J., 2016. Increasing harvest maturity of whole-plant corn silage reduces methane emission of lactating dairy cows. J. Dairy Sci. 99, 354-368.

Himmelsbach, D.S., Barton II, F.E., Windham, W.R., 1983. Comparisons of carbohydrate, lignin, and protein ratios between grass species by cross polarizationmagic angle spinning carbon-13 nuclear magnetic resonance. J. Agric. Food Chem. 31, 401-404.

Johnson, R.R., Dehority, B.A., Parson, J.L., Scott, H.W., 1962. Discrepancies between grasses and alfalfa when estimating nutritive value from in vitro cellulose digestibility by rumen microorganisms. J. Anim. Sci. 21, 892-896.

Joseleau, J., Miksche, G.E., Yasuda, S., 1976. Structural variation of Arundo donax lignin in relation to growth. Holzforschung 31, 19-20.

Jung, H.G., Buxton, D.R., 1994. Forage quality variation among maize inbreds: relationships of cell-wall composition and in vitro degradability for stem internodes. J. Sci. Food Agric. 66, 313-322.

Jung, H.G., Casler, M.D., 2006. Maize stem tissues: impact of development on cell wall degradability. Crop Sci. 46, 1801-1809.

Jung, H.G., Deetz, D.A., 1993. Cell wall lignification and degradation. In: Jung, H.G., Buxton, D.B., Hatfield, R.D., Ralph, J. (Eds.), Forage Cell Wall Structure and Digestibility. American Society of Agronomy, Madison, WI, pp. 315-346.

Jung, H.G., Lamb, J.F.S., 2003. Identification of lucerne stem cell wall traits related to in vitro neutral detergent fibre digestibility. Anim. Feed Sci. Technol. 110, 17-29.

Jung, H.G., Mertens, D.R., Payne, A.J., 1997. Correlation of acid detergent lignin and Klason lignin with digestibility of forage dry matter and neutral detergent fiber. J. Dairy Sci. 80, 1622-1628.

Jung, H.G., Samac, D.A., Sarath, G., 2012. Modifying crops to increase cell wall digestibility. Plant Sci. 185-186, 65-77.

Jung, H.G., Vogel, K.P., 1986. Influence of lignin on digestibility of forage cell wall material. J. Anim. Sci. 62, 1703-1712. 


\section{CHAPTER 3}

Jung, H.G., Vogel, K.P., 1992. Lignification of switchgrass (Panicum virgatum) and big bluestem (Andropogon gerardii) plant parts during maturation and its effect on fibre degradability. J. Sci. Food Agric. 59, 169-176.

Jurak, E., Punt, A.M., Arts, W., Kabel, M.A., Gruppen, H., 2015. Fate of carbohydrates and lignin during composting and mycelium growth of Agaricus bisporus on wheat straw based compost. PLoS One 10.1371, 1-16.

Lam, T.B.T., Iiyama, K., Stone, B.A., 1996. Lignin and hydroxycinnamic acids in walls of brown midrib mutants of sorghum, pearl millet and maize stems. J. Sci. Food Agric. 71, 174-178.

Martínez, P.M., Punt, A.M., Kabel, M.A., Gruppen, H., 2016. Deconstruction of lignin linked $p$-coumarates, ferulates and xylan by $\mathrm{NaOH}$ enhances the enzymatic conversion of glucan. Bioresour. Technol. 216, 44-51.

Morrison, T.A., Buxton, D.R., 1993. Activity of phenylalanine ammonia-lyase, tyrosine ammonia-lyase, and cinnamyl alcohol dehydrogenase in the maize stalk. Crop Sci. 33, 1264-1268.

Morrison, T.A., Jung, H.G., Buxton, D.R., Hatfield, R.D., 1998. Cell-wall composition of maize internodes of varying maturity. Crop Sci. 38, 455-460.

Morrison, T.A., Kessler, J.R., Buxton, D.R., 1994a. Maize internode elongation patterns. Crop Sci. 34, 1055-1060.

Morrison, T.A., Kessler, J.R., Hatfield, R.D., Buxton, D.R., 1994b. Activity of two lignin biosynthesis enzymes during development of a maize internode. J. Sci. Food Agric. 65, 133-139.

Ralph, J., Hatfield, R.D., 1991. Pyrolysis-GC-MS characterization of forage materials. J. Agric. Food Chem. 39, 1426-1437.

Ralph, J., Hatfield, R.D., Quideau, S., Helm, R.F., Grabber, J.H., Jung, H.G., 1994. Pathway of $p$-coumaric acid incorporation into maize lignin as revealed by NMR. J. Am. Chem. Soc. 116, 9448-9456.

Sewalt, V.J.H., Ni, W., Jung, H.G., Dixon, R.A., 1997. Lignin impact on fiber degradation: increased enzymatic digestibility of genetically engineered tobacco (Nicotiana tabacum) stems reduced in lignin content. J. Agric. Food Chem. 45, 1977- 


\section{CHAPTER 3}

1983.

Sommerfeldt, J.L., Schingoethe, D.J., Muller, L.D., 1970. Brown-midrib corn silage for lactating dairy cows. J. Dairy Sci. 62, 1611-1618.

Terashima, N., Fukushima, K., He, L.F., Takabe, K., 1993. Comprehensive model of the lignified plant cell wall. In: Jung, H.G., Buxton, D.B., Hatfield, R.D., Ralph, J. (Eds.), Forage Cell Wall Structure and Digestibility. American Society of Agronomy, Madison, WI, pp. 247-270.

Tolera, A., Sundstol, F., 1999. Morphological fractions of maize stover harvested at different stages of grain maturity and nutritive value of different fractions of the stover. Anim. Feed Sci. Technol. 81, 1-16.

Vailhe, M.A.B., Migne, C., Cornu, A., Maillot, M.P., Grenet, E., Besle, J.M., 1996. Effect of modification of the $O$-methyltransferase activity on cell wall composition, ultrastructure and degradability of transgenic tobacco. J. Sci. Food Agric. 72, 385-391. Van Dongen, F.E.M., Van Eylen, D., Kabel, M.A., 2011. Characterization of substituents in xylans from corn cobs and stover. Carbohydr. Polym. 86, 722-731.

Van Soest, P.J., 1967. Development of a comprehensive system of feed analysis and its application to forages. J. Anim. Sci. 26, 119-128.

Van Soest, P.J., McQueen, R.W., 1973. The chemistry and estimation of fibre. Proc. Nutr. Soc. 32, 123-130.

Van Soest, P.J., Robertson, J.B., Lewis, B.A., 1991. Methods for dietary fiber, neutral detergent fiber, and nonstarch polysaccharides in relation to animal nutrition. J. Dairy Sci. 74, 3583-3597. 
CHAPTER 3

Supplementary information for:

Lignin composition is more important than content for corn stem cell wall degradation

Yuan He, Thibaut M.B. Mouthier, Mirjam A. Kabel, Jan Dijkstra, Wouter H. Hendriks, Paul C. Struik, John W. Cone 
CHAPTER 3

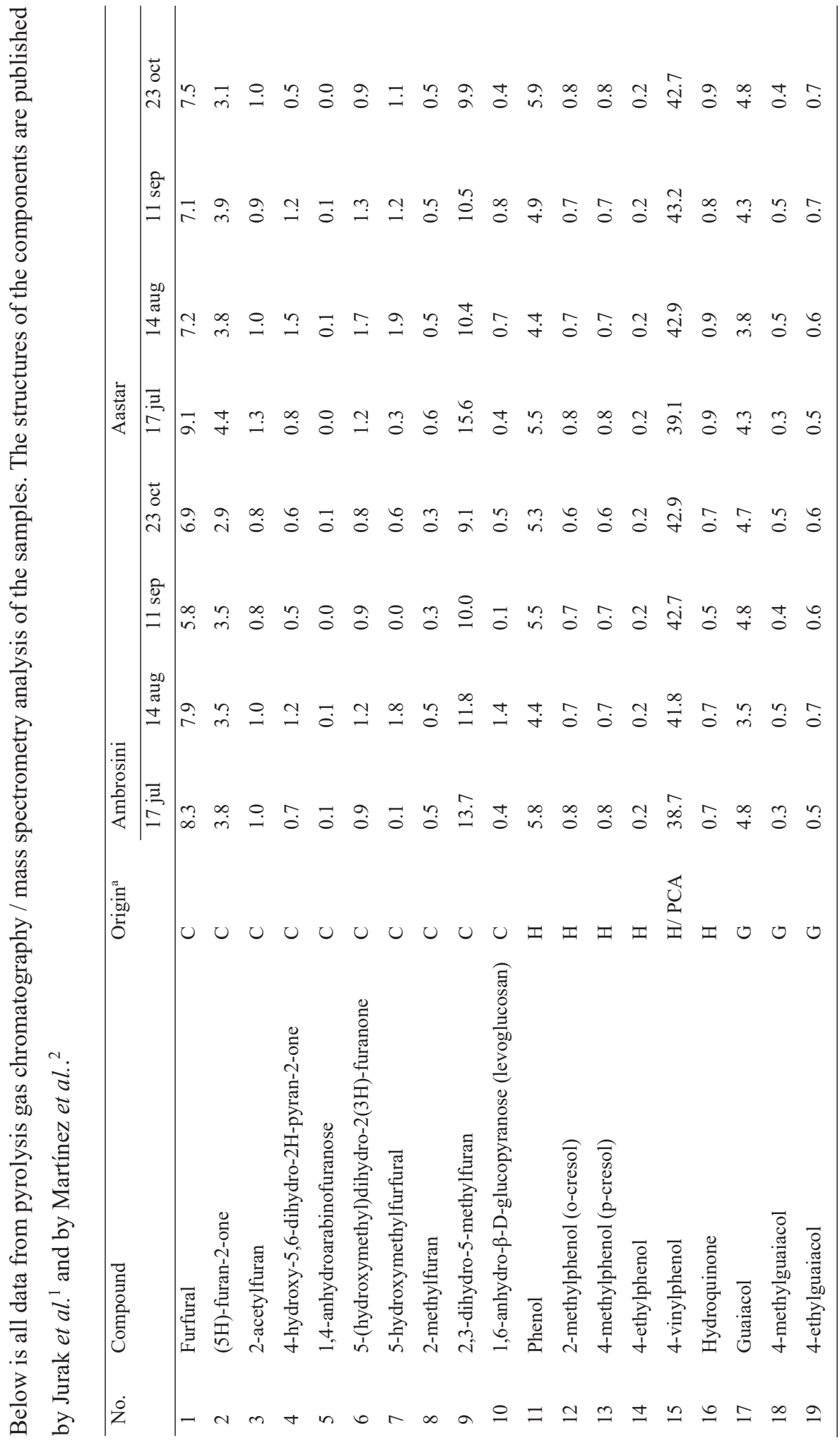


CHAPTER 3

㦴

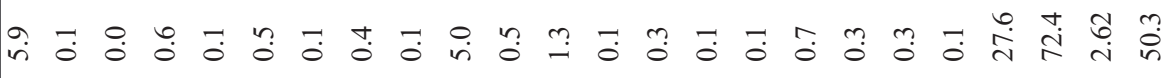

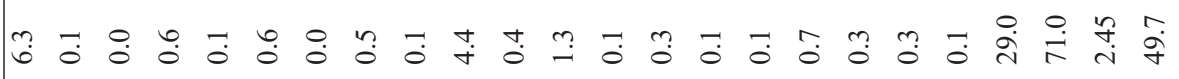

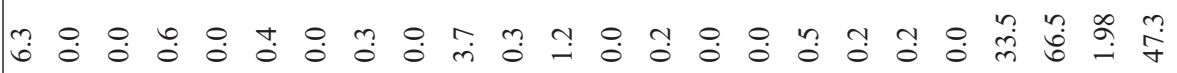

न न: :

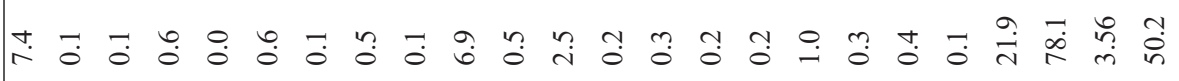

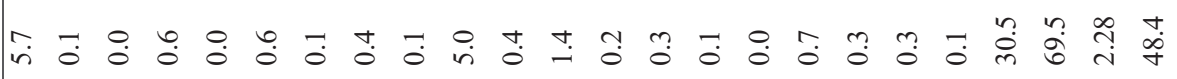

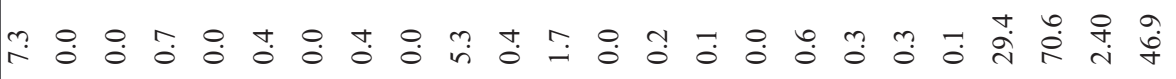

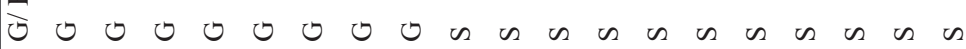

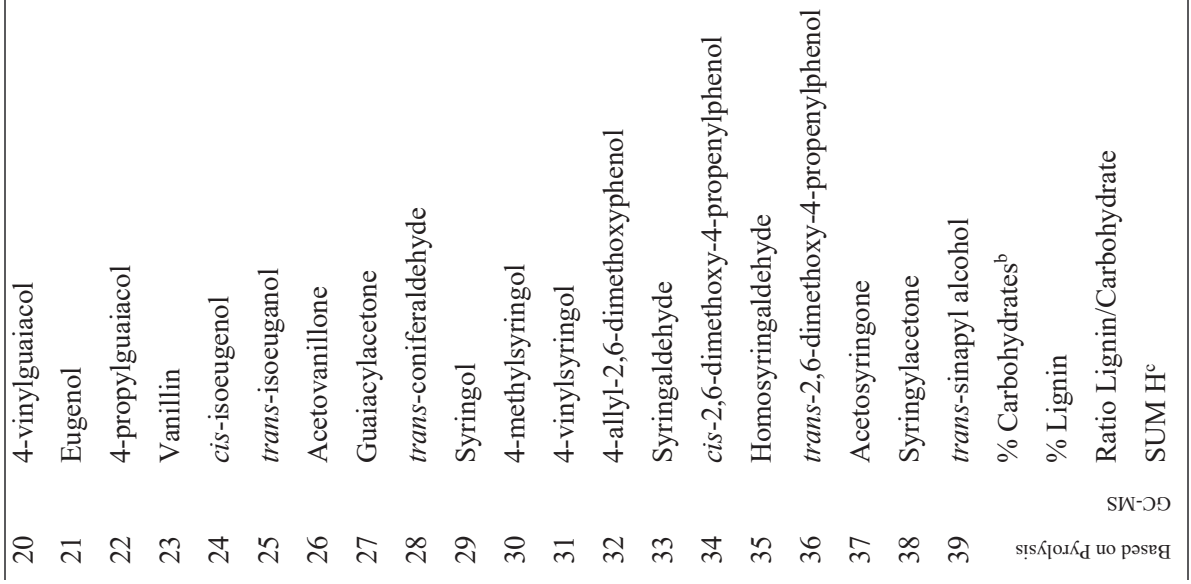




\section{CHAPTER 3}

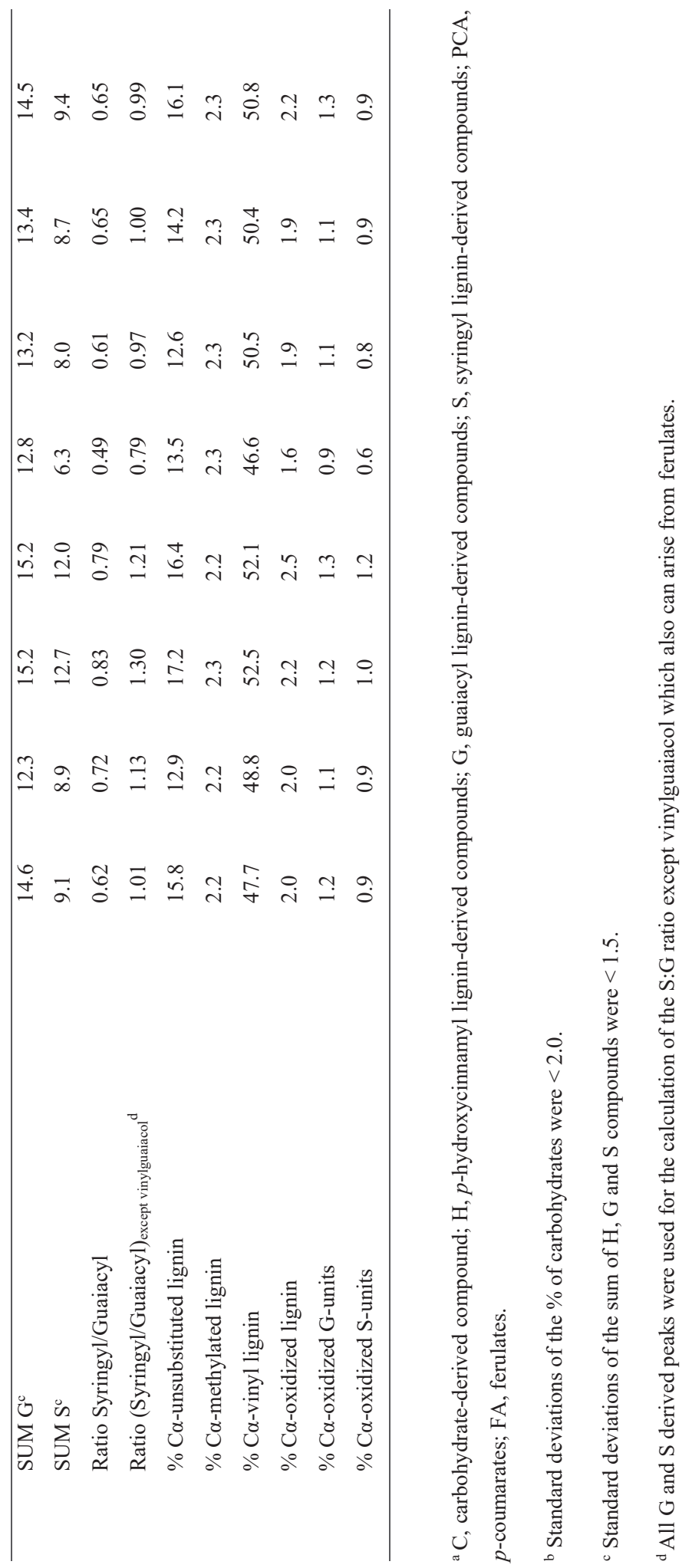


CHAPTER 3

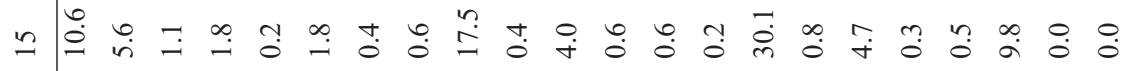

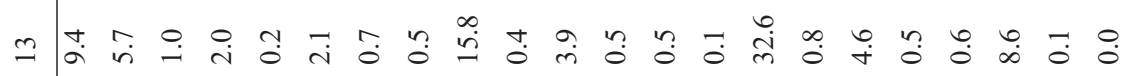

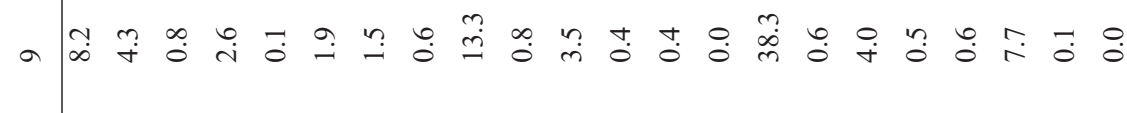

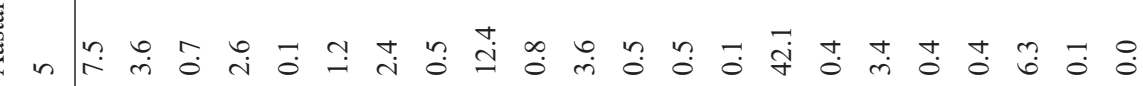

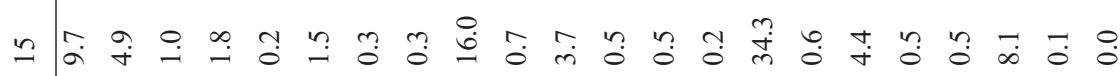

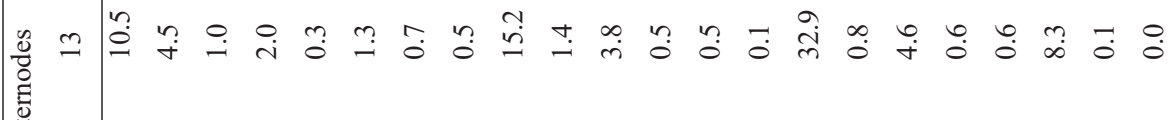
兽

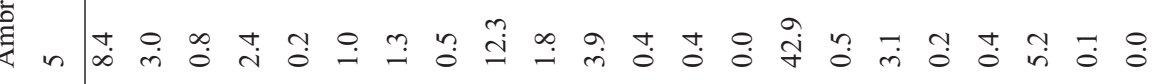

咅

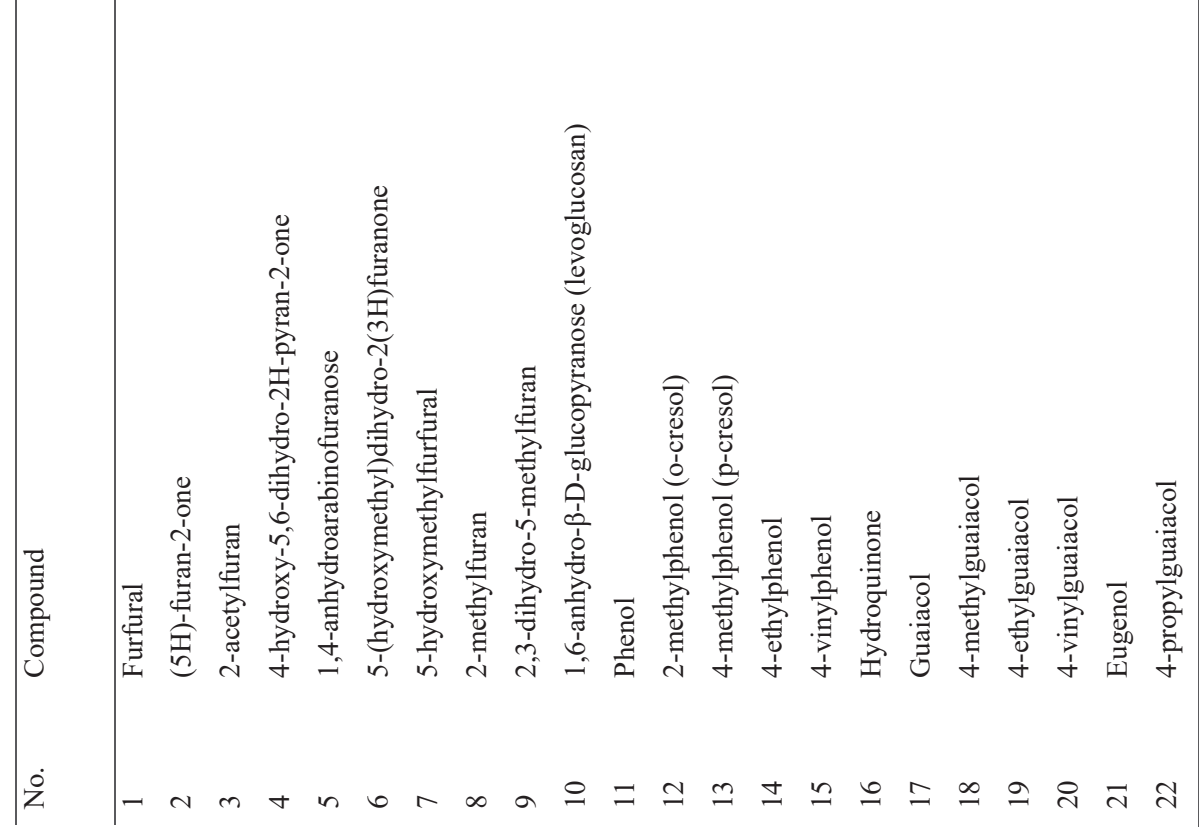




\section{CHAPTER 3}

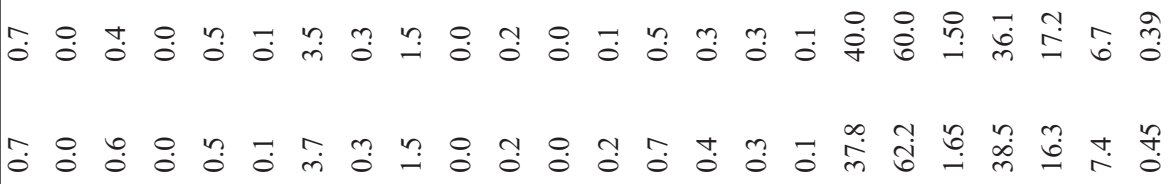

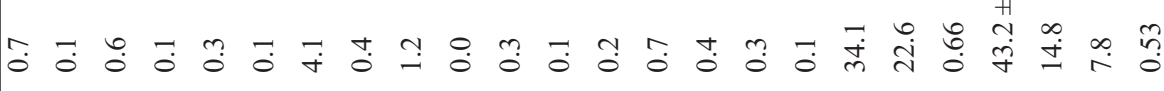

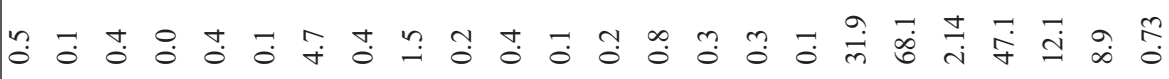

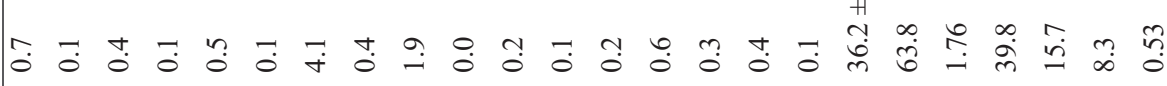
㐭

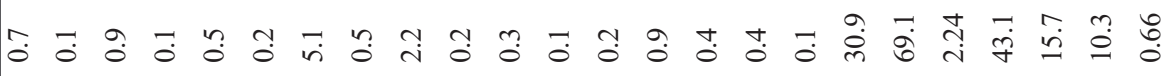

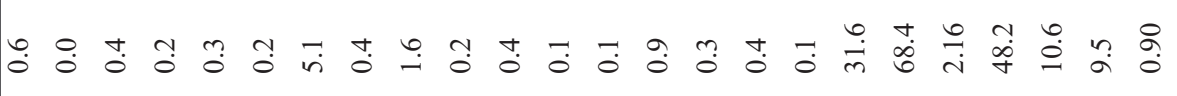

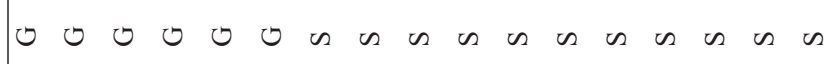

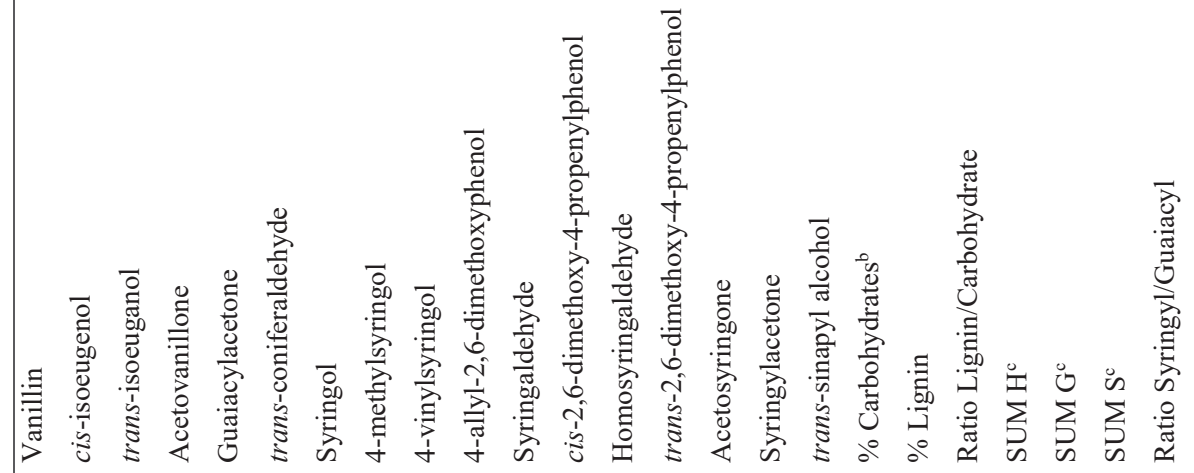

तิ 
CHAPTER 3
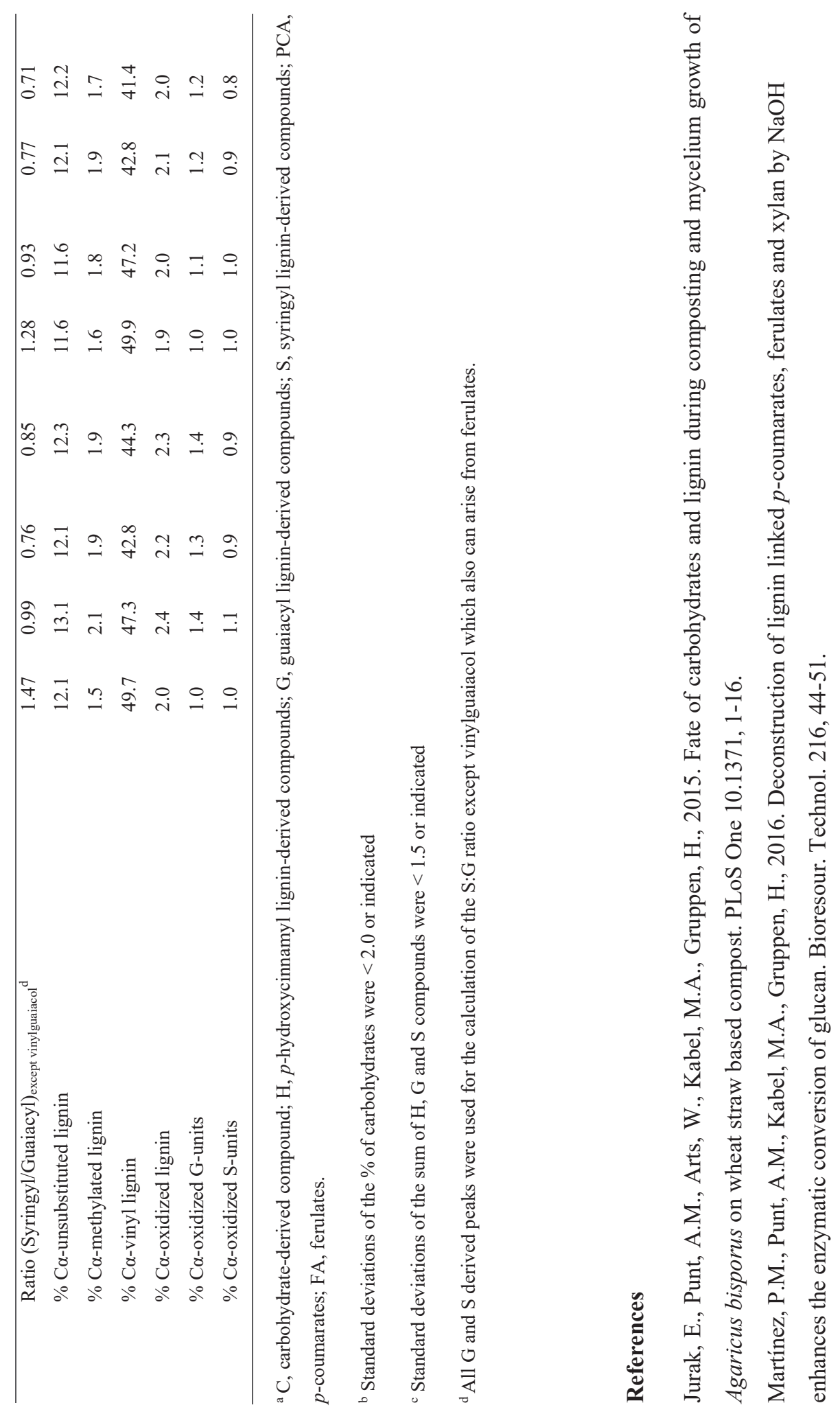


\section{Chapter 4}

\section{The nutritional value of the lower corn stem cannot be improved by ensiling nor by a fungal treatment}

Yuan Hea , Jan Dijkstra ${ }^{\mathrm{a}}$, Anton S.M. Sonnenberg ${ }^{\mathrm{b}}$, Thibaut M.B. Mouthier ${ }^{\mathrm{c}}$, Mirjam A. Kabel $^{\mathrm{c}}$, Wouter H. Hendriks ${ }^{\mathrm{a}}$, John W. Cone ${ }^{\mathrm{a}}$

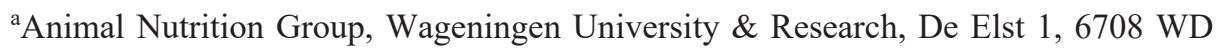
Wageningen, the Netherlands

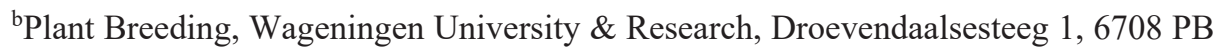
Wageningen, the Netherlands

${ }^{c}$ Food Chemistry, Wageningen University \& Research, Bornse Weilanden 9, 6708WG Wageningen, the Netherlands

Published in Animal Feed Science and Technology 2019, 247, 92-102 


\section{CHAPTER 4}

\section{Abstract}

The effect of ensiling and fungal treatment on the chemical composition and on in vitro gas production, an indication of rumen degradability, of corn stems was studied. Stems from two corn cultivars (LG30211 and MZP8057) were separated into three parts: upper (above internode 12 up to and including internode 15), middle (above internode 8 up to and including internode 11), and lower stem (above internode 5 up to and including internode 7). The three parts of the stems were ensiled for 1, 2, 4, and 8 weeks and the lower stem was treated with the white-rot fungi Lentinula edodes and Pleurotus eryngii for 3, 6, and 9 weeks. The dry matter content decreased and the acid detergent fiber (ADF) and acid detergent lignin (ADL) content increased from the top to the bottom in the stem. Upon ensiling, the neutral detergent fiber, ADF and ADL content increased. The gas production between 3 and $20 \mathrm{~h}$, a measure of cell wall degradability in rumen fluid, did not change after ensiling, but gas production within $3 \mathrm{~h}$ and within $72 \mathrm{~h}$ decreased after ensiling. The acetic acid content and the proportion of ammonia$\mathrm{N}$ in total $\mathrm{N}$ increased, and $\mathrm{pH}$ decreased, after 1 week of ensiling and did not show a clear trend from 1 to 8 weeks. The ADL and cellulose content of the lower part of the stem of both corn cultivars increased after fungal treatment and the hemicellulose content decreased except for the lower stem of MZP8057 treated with P. eryngii. The ratio of syringyl to guaiacyl compounds increased after fungal treatment. The gas production between 3 and $20 \mathrm{~h}$ and within $72 \mathrm{~h}$ decreased after fungal treatment. Both ensiling and fungal treatment cannot improve the degradability of the investigated corn stems.

Keywords: ensiling; fungal treatment; in vitro gas production; lower stem 


\subsection{Introduction}

Corn is an important economic crop in several countries, including China. It is estimated that approximately $2.4 \times 10^{11} \mathrm{~kg}$ of corn stover, the residue after grain harvesting consisting of leaves and stems, is generated annually (Zuo et al., 2015). However, only $10 \%$ of the corn stover is used as feed (Yang and Gao, 2016). A relatively common method to treat corn stover is field burning, thereby contributing to environmental pollution. Even though the corn stover can be used as feedstuff by ruminant animals, its highly lignified cell walls and low degradability impede its further utilization in animal production system. As the degradation of corn stems is less than that of corn leaves (Tang et al., 2008; Verbic et al., 1995), proper pretreatment methods to increase the degradability of corn stems by ruminant animals may promote its utilization as feed.

Lignin in forages is negatively related with cell wall degradation in the rumen (Boon et al., 2005; Arora and Sharma, 2009; Tuyen et al., 2012), due to its direct or indirect linkages to cellulose and hemicellulose (Susmel and Stefanon, 1993; Jeffries, 1994; Jalc, 2002; Vanholme et al., 2010; Ding et al., 2012). Methods that can decrease the lignin content or break down the linkages to liberate the potentially degradable carbohydrates for rumen microbes should improve the degradability. Chemical treatments with acids or alkaline have been shown to increase the degradation of corn stover (Hendriks and Zeeman, 2009) and improve the performance of ruminant animals (Anastacio et al., 2009; Jami et al., 2014). However, these methods often lead to environmental pollution and may be harmful to farm workers. Alternatively, during ensiling lactic acid bacteria produce lactic acid causing a decrease in $\mathrm{pH}$, which is a commonly used method to preserve forages. It is reported that the neutral detergent fiber (NDF) digestibility of corn silage increased with advanced storage time (Hallada et al., 2008). Because the fiber fractions of corn silage cannot be fermented by lactic acid bacteria, the increased NDF digestibility may result from hydrolysis by lactic acid. In contrast, others reported that the NDF digestibility of corn silage did not improve during ensiling (Cone et al., 2008; Der Bedrosian et al., 2012). The discrepancy between results may be due to different corn cultivars, differing in NDF content and degradability, used in previous experiments (Cone et al., 2008; Der Bedrosian et al., 2012; Hallada et al., 2008). It is unknown whether the influence of ensiling on NDF degradability depends on the NDF content and degradability of the corn plants. Besides, 


\section{CHAPTER 4}

the materials used in these experiments were whole corn plants, and the effects of ensiling may differ when only corn stems are used.

Several fungal species can selectively degrade lignin in crop residues, such as wheat straw and rice straw, increasing the ruminal degradation of the feedstuff (Tuyen et al., 2013; Van Kuijk et al., 2015). Among the fungal species investigated earlier, Lentinula edodes showed the greatest improvement in the in vitro gas production (IVGP) of various agricultural by-products (Van Kuijk et al., 2015) and Pleurotus eryngii had potential to increase IVGP of corn stover (Tuyen et al., 2013). However, in comparison to the control, the nutritional value of corn stover treated with $L$. edodes and $P$. eryngii was lower after 3 weeks of fungal incubation, and did not significantly differ after 6 weeks of fungal incubation (Tuyen et al., 2013), which leads to the hypothesis that longer incubation times may improve the effectiveness of fungal treatment. Lynch et al. (2014) found that the changes in chemical composition of the lower parts (expected to be higher in lignin content and less degradable than the upper parts) of corn stems treated with Pleurotus ostreatus or Trametes versicolor were not beneficial to the feed value. Nevertheless, it is unknown whether the degradation of lower parts of stems of different corn cultivars can be enhanced by L. edodes and P. eryngii with extended incubation time (from 6 weeks to 9 weeks). Increasing the nutritional value of the lower parts of corn stems may improve the utilization of corn stover, since the lower parts of corn stems has a lower nutritional value than the upper parts, and is a major obstacle for wide utilization of corn stover.

The objectives of the present study were to investigate the changes in chemical composition and degradability of corn stem during ensiling and upon fungal treatments.

\subsection{Material and methods}

\subsubsection{Corn stem harvesting}

The seeds of two corn cultivars (LG30211 and MZP8057) were sown on 16 May 2015 at the experimental field of Unifarm in Wageningen (the Netherlands). Whole corn plants of the two cultivars were harvested in October 2015 by cutting plants $5 \mathrm{~cm}$ above the ground. After harvesting, the leaves and grains were separated from the stems. The stems were separated into three parts: upper (above internode 12 up to and including 
internode 15; internodes counted from the ground), middle (above internode 8 up to and including internode 11), and lower stem (above internode 5 up to and including internode 7), with expected lignin content of stems to be greater and degradability to be less in the lower than the upper part of the stem.

\subsubsection{Experiment 1: corn stem silage}

The three parts of the stems were chopped into $1-2 \mathrm{~cm}$ pieces and ensiled in 0.51 anaerobic glass jars (IKEA, Leiden, The Netherlands) for 1, 2, 4, and 8 weeks at room temperature $\left(20^{\circ} \mathrm{C}\right)$ in duplicate. Each jar was filled with approximately $260 \mathrm{~g}$ (wet weight) corn stems without a headspace. The chopped fresh stems served as duplicate samples for week 0 and were stored at $-20^{\circ} \mathrm{C}$ directly. After ensiling, the samples were taken out of the glass jars and stored at $-20{ }^{\circ} \mathrm{C}$.

The samples were thawed at room temperature and separated into two portions. Thirty $\mathrm{g}$ of the sample was weighed into a stomacher bag, diluted with $270 \mathrm{ml}$ distilled water and mixed vigorously for $5 \mathrm{~min}$, and the fluid was used to determine $\mathrm{pH}$, ammonia, and volatile fatty acids (VFA) content. The other part was oven-dried at $70{ }^{\circ} \mathrm{C}$ for $72 \mathrm{~h}$, ground to pass a $1 \mathrm{~mm}$ sieve using a Peppink 100 A N cross-beater mill (Peppink, Deventer, The Netherlands) and analyzed for dry matter (DM), ash, nitrogen (N), NDF, acid detergent fiber (ADF), acid detergent lignin (ADL), and used for in vitro gas production.

\subsubsection{Experiment 2: fungal treatment with lower stem}

\subsubsection{Fungal strains and spawn preparation}

The fungi L. edodes (strain MES 11910) and P. eryngii (strain MES 12975) were cultured on malt extract agar plates (10 g malt extract and $20 \mathrm{~g}$ bacteriological agar per 1 of water) at $24{ }^{\circ} \mathrm{C}$ until most of the plate surface was covered with mycelium. Pieces of the colonized agar plates were added to sterilized sorghum grains and incubated at $24{ }^{\circ} \mathrm{C}$ and $70 \%$ relative humidity in a climate controlled chamber until all grains were colonized by the mycelium which occurred 2 weeks after start of the incubation. After preparation, the spawn was kept at $4{ }^{\circ} \mathrm{C}$ until further use. 


\section{CHAPTER 4}

\subsubsection{Substrate preparation and inoculation}

The lower stem parts were chopped into approximately $3 \mathrm{~cm}$ particle length. Water was added to the substrates and left for 3 days to allow the water to penetrate the material fully. After removal of the excess water, $200 \mathrm{~g}$ of substrate was weighed into 1.21 polypropylene containers with a filter cover (model TP1200+TPD1200 XXL Combiness, Nazareth, Belgium), through which air can pass. The containers with substrates were sterilized by autoclaving for $1 \mathrm{~h}$ at $121{ }^{\circ} \mathrm{C}$ and then kept at room temperature until further use. To each container, $5 \mathrm{~g}$ spawn was added and mixed with the substrate under aseptic conditions. The inoculated substrates were incubated in triplicate for 3,6 , and 9 weeks at $24{ }^{\circ} \mathrm{C}$. Autoclaved uninoculated substrates were used as control (week 0). After inoculation, the substrates were freeze-dried and ground through a $1 \mathrm{~mm}$ sieve using a Peppink 100 AN cross-beater mill (Peppink, Deventer, The Netherlands) and analyzed for DM, ash, N, NDF, ADF, ADL, syringyl and guaiacyl compounds, and used for in vitro gas production.

\subsubsection{In vitro gas production}

The in vitro gas production technique was performed according to the procedure described by Cone et al. (1996). Rumen fluid was collected $2 \mathrm{~h}$ after the morning feeding from three non-lactating rumen fistulated cows, fed grass silage based diets. The fluid was pooled, stored in a warm insulated flask filled with $\mathrm{CO}_{2}$, filtered through cheesecloth, and mixed with an anaerobic buffer/mineral solution as described by Cone et al. (1996), under continuous flushing with $\mathrm{CO}_{2}$. Approximately $0.5 \mathrm{~g}$ organic matter $(\mathrm{OM})$ of the dried samples was incubated with $60 \mathrm{ml}$ buffered rumen fluid (one part of rumen fluid and two parts of buffer) in $250 \mathrm{ml}$ Schott (Mainz, Germany) incubation bottles at $39{ }^{\circ} \mathrm{C}$ in a shaking water bath. Each sample was run in one bottle each time and each sample was run twice. Gas production was recorded for $72 \mathrm{~h}$ with an automated system and expressed on an OM basis.

The cumulative gas production data were fitted to a three phasic mathematical model as described by Cone et al. (1996) and Groot et al. (1996) using the NLIN procedure in SAS 9.3. The gas production curves were divided into three different sub-curves, each with an asymptote (A), a half-time value of A (B) and a shape parameter (C). Sub-curve 1 corresponds to the gas production between 0 and $3 \mathrm{~h}$ incubation, caused by 
fermentation of the water-soluble components. Sub-curve 2 corresponds to the gas production between 3 and $20 \mathrm{~h}$ caused by fermentation of the non-soluble components (Cone et al., 1996). The half-time value of the second sub-curve (B2) is the incubation time (h) needed to reach half of A2, representing a measure for the rate of cell wall degradation. To enable robust curve fitting, A1 was set as the cumulative gas production at $3 \mathrm{~h}$, and $\mathrm{A} 2$ was set as the cumulative gas production at $20 \mathrm{~h}$, minus that at $3 \mathrm{~h}$ (Cone et al., 1997).

\subsubsection{Chemical analysis}

The DM content was determined by drying the samples in an oven at $103{ }^{\circ} \mathrm{C}$ for $4 \mathrm{~h}$. Ash was determined after combustion at $550{ }^{\circ} \mathrm{C}$ for $3 \mathrm{~h}$ in a muffle furnace. The NDF content was determined with a heat stable amylase according to the method of Van Soest et al. (1991). The ADF and ADL content were determined by the method of Van Soest and McQueen (1973). The cellulose (CELL) content was calculated as the difference between ADF and ADL and the hemicellulose (HC) content was calculated as the difference between NDF and ADF. Nitrogen was determined by the Kjeldahl method, and crude protein $(\mathrm{CP})$ was calculated as $\mathrm{N} \times 6.25$. The rest fraction represents the non-fiber, non-protein components in OM and was calculated as 1000-NDF-CP. The NDF, ADF, ADL, CELL, HC, CP and rest fraction contents were expressed on an OM basis.

The $\mathrm{pH}$ was measured immediately using a pH meter (Hanna Instruments $\mathrm{pH}$ 300GLP, Amorim Povoa de Varzim, Portugal) by merging the detector into the fluid until the $\mathrm{pH}$ value in the $\mathrm{pH}$ meter is constant. Before measuring $\mathrm{pH}$, the $\mathrm{pH}$ meter was calibrated according to manufacturer's instructions. Thirty $\mathrm{ml}$ of the fluid was centrifuged at $25,000 \times g$ for $10 \mathrm{~min}$, and two portions of the supernatant were collected. The supernatants were acidified with equal volumes of trichloroacetic acid for ammonia analysis and with $0.85 \%$ ortho-phosphoric acid for VFA analysis. Ammonia-N was determined by a colorimetric method (Scheiner, 1976) and VFA was determined by gas chromatography (Fisons HRGC MEGA2, Milan, Italy), based on the method described by Taweel et al. (2005). 


\section{CHAPTER 4}

\subsubsection{Analytical pyrolysis-GC/MS analysis}

Pyrolysis was performed by a micro-furnace pyrolyzer and gas chromatography/mass spectrometry as previously described by He et al. (2018). Briefly, pyrolysis of a $100 \mu \mathrm{g}$ sample was carried out in a micro-furnace pyrolyzer connected to a gas chromatograph coupled to a thermo mass selective detector. Species coming from lignin units and species coming from $p$-coumaric and ferulic acids were distinguished assuming more than $80-85 \%$ of $p$-coumaric and ferulic acids considered to be part of lignin and not xylan. The compounds were identified and the relative abundance of each compound was calculated based on Ralph and Hatfield (1991) and Jurak et al. (2015). One sample from the triplicate samples in the fungal treatment experiment was analyzed, though in triplicate, using Py-GC/MS. The syringyl:guaiacyl (S:G) was calculated by dividing the sum of the abundance of the syringyl compounds by the sum of the abundance of the guaiacyl compounds (Supplement 4.S1).

\subsubsection{Statistical analysis}

The generalised linear model procedure in SAS/STAT ${ }^{\circledR} 9.3$ (Statistical Analysis System, Cary, NC, USA) was used to analyze the data. For the chemical compositions, $\mathrm{pH}, \mathrm{VFA}$, ammonia and in vitro gas production parameters of the samples in the first experiment, corn cultivar (LG30211 and MZP8057), stem fraction (lower, middle, and upper stem), ensiling time (0, 1, 2, 4, and 8 weeks), and their 2-way and 3-way interactions were included in the model as fixed effects. For the chemical compositions and in vitro gas production of the samples in the second experiment, corn cultivar (LG30211 and MZP8057), fungal species (L. edodes and P. eryngii), treatment time (0, 3, 6, and 9 weeks), and their 2-way and 3-way interactions were included in the model as fixed effects. Because Py-GC/MS analysis was performed on only one of the triplicate samples, only the 2-way interactions between corn cultivar and fungal species, corn cultivar and treatment time, and fungal species and treatment time were included in the model. Differences among main effects were analyzed using Tukey-Kramer's multiple comparison procedure. Effects were declared significant at $P \leq 0.05$, and trends at $0.05<P \leq 0.10$. 
CHAPTER 4

\subsection{Results}

\subsubsection{Chemical compositions of fresh and ensiled corn stems}

The DM, ash, CP, NDF, ADF, and ADL content, as well as the rest fraction content, of the upper, middle and lower part of the stems of two corn cultivars before and after ensiling is shown in Table 4.1. Also shown is the ratio of lignin to potentially rumen degradable fiber (pRDF; calculated as the difference between NDF and ADL) (ADL:pRDF) of the stems from the two corn cultivars before and after ensiling (Table 4.1). As these chemical compositions did not differ significantly among stems ensiled for 1, 2, 4, and 8 weeks, as such only data of the stems ensiled for 8 weeks are shown. The DM content was significantly higher in the upper internodes compared to the lower internodes for both corn cultivars, with LG30211 having a higher DM content than MZP8057. Ensiling decreased the DM content significantly, except for the lower stem of MZP8057. The ash content was lowest in the upper internodes for both cultivars. The CP content decreased from the lower internodes to the upper internodes only for LG30211 and was not influenced by the ensiling. The NDF and ADF content increased, and the rest fraction decreased during ensiling. The ADL content increased from upper to lower internodes. There was no effect of ensiling on the ADL:pRDF. The ADL:pRDF was higher in stems of MZP8057 than LG30211.

\subsection{2 pH, VFA concentration and ammonia proportion of fresh and ensiled corn stem}

The $\mathrm{pH}$, acetic acid concentration and ammonia- $\mathrm{N}$ proportion (as a fraction of total $\mathrm{N}$ ) of different internodes from the two corn cultivars, before and after ensiling, are shown in Figure 4.1. The $\mathrm{pH}$ decreased significantly after ensiling. For both cultivars, the $\mathrm{pH}$ of the three parts of the stem remained stable after 4 weeks ensiling. The $\mathrm{pH}$ of the three parts of the stem of MZP8057 ensiled for 8 weeks decreased from upper to lower stem. Acetic acid was the only VFA that was detected in the samples and increased significantly after ensiling. For all the stems of each cultivar, the acetic acid concentration remained constant after 2 weeks ensiling. Compared with the fresh internodes, the ensiled internodes contained a higher proportion of ammonia-N (as a fraction of total $\mathrm{N}$ ). The lower stem of LG30211 showed a lower ammonia-N proportion than that of the upper and middle stem, which was not observed in MZP8057. 
CHAPTER 4

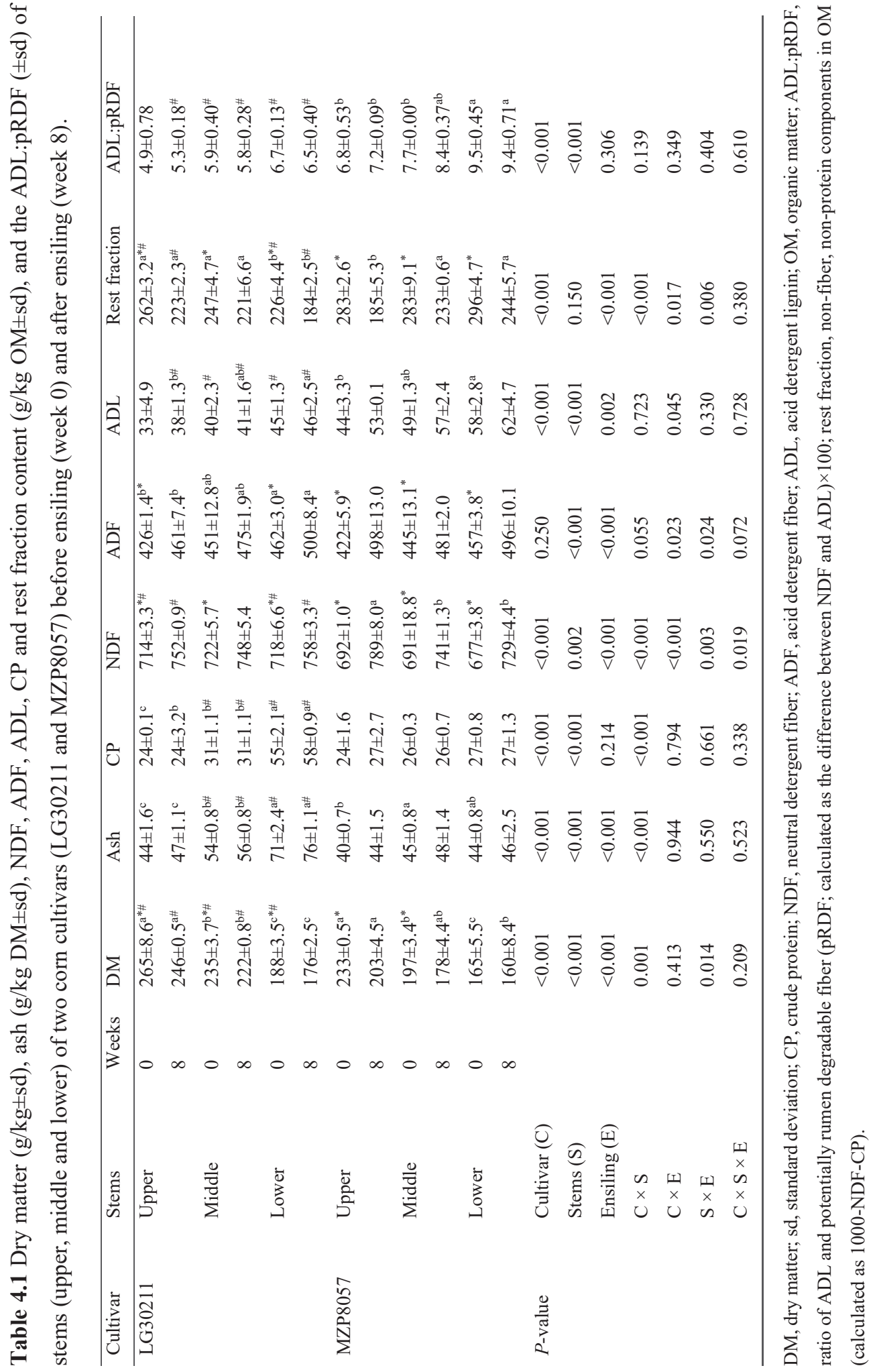


CHAPTER 4

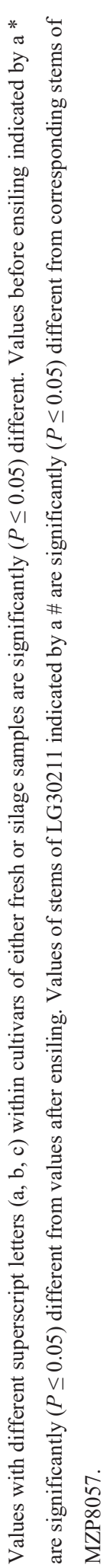




\section{CHAPTER 4}
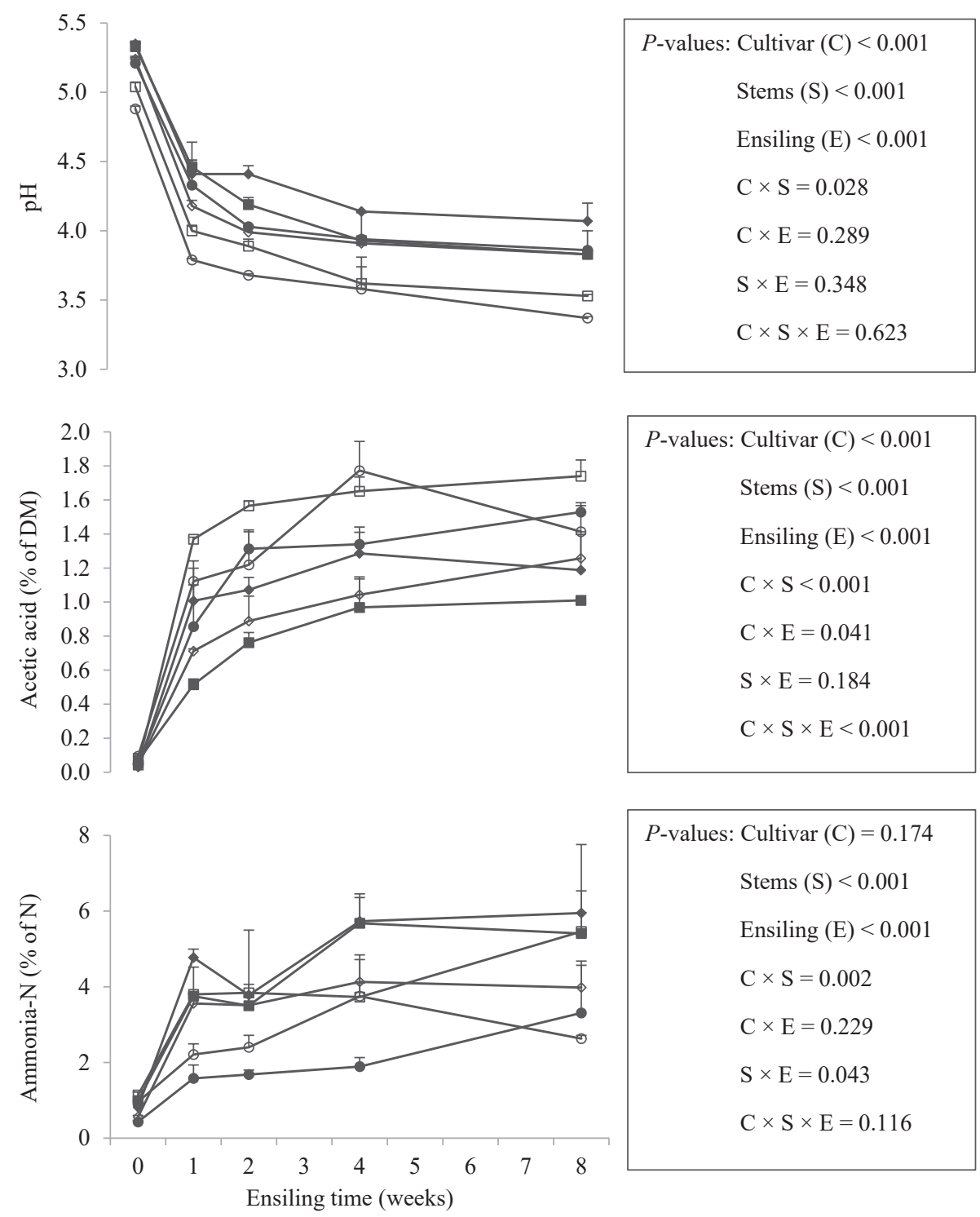

Figure 4.1 pH and the concentrations of acetic acid (\% of DM) and ammonia-N (\% of $\mathrm{N}$ ) of upper, middle and lower stems from two corn cultivars (LG30211 and MZP8057) ensiled for $0,1,2,4$ or 8 weeks. = upper stem of LG30211; $\mathbf{\square}=$ middle stem of LG30211; • = lower stem of LG30211; $\diamond=$ upper stem of MZ8057; $\square=$ m iddle stem of MZ8057; $\circ=$ lower stem of MZ8057. Error bars represent standard deviations $(\mathrm{n}=$ 2). 
CHAPTER 4

\subsubsection{In vitro gas production parameters of fresh and ensiled corn stems}

The in vitro gas production parameters of different internodes from the two corn cultivars, before and after ensiling, are shown in Table 4.2. Again, these parameters were not significantly different among internodes ensiled for 1, 2, 4, and 8 weeks, and therefore only data of the internodes ensiled for 8 weeks are shown. Gas production within $3 \mathrm{~h}$ (A1) decreased after ensiling. No effect of ensiling on gas produced between 3 and $20 \mathrm{~h}$ (A2) was observed and A2 was higher for the upper and middle internodes than the lower internodes for both cultivars. The gas production within $72 \mathrm{~h}$ (GP72) decreased after ensiling and was higher for the upper and middle internodes compared with the lower internodes. Ensiling increased the half time of the second phase (B2) significantly, indicating a decreased rate of fermentation. With MZP8057, the value of B2 was higher for the lower internode compared with the middle and upper internode, whereas no differences in B2 for LG30211 internodes were observed.

\subsubsection{Chemical compositions of the lower stem before and after fungal treatment}

Table 4.3 shows the DM, ash, CP, CELL, HC, ADL and the rest fraction content, ADL:pRDF and the S:G of the lower stem from the two corn cultivars treated with the two fungal species. Compared with the untreated lower stem of MZP8057, that of LG30211 showed a lower ADL content, rest fraction content and ADL:pRDF and a higher HC content. The HC content in LG30211 decreased up to 6 weeks of treatment with L. edodes. When MZP8057 was treated with P. eryngii, the HC content was highest after 3 weeks of treatment and decreased when treated longer. L. edodes decreased the HC content in MZP8057 after 3 weeks of treatment and no further decrease was observed. The CELL content in both corn cultivars increased by the fungal treatment except for MZP8057 treated with L. edodes. The ADL content and ADL:pRDF of the lower stem of both corn cultivars treated with either P. eryngii or $L$. edodes was higher than that of the untreated internodes. The $\mathrm{S}: \mathrm{G}$ of both cultivars increased numerically after fungal treatment. 


\section{CHAPTER 4}

Table 4.2 In vitro gas production parameters (A1, A2 and GP72, $\mathrm{ml} / \mathrm{g} \mathrm{OM} \pm \mathrm{sd}$; B2, $\mathrm{h} \pm \mathrm{sd}$ ) of fermentation of stems (upper, middle and lower) in rumen fluid of two corn cultivars (LG30211 and MZP8057) before ensiling (week 0) and after ensiling (week 8)

\begin{tabular}{lllllll}
\hline Cultivar & Stems & Weeks & A1 & A2 & GP72 & B2 \\
\hline LG30211 & Upper & 0 & $43 \pm 0.4^{* \#}$ & $139 \pm 4.7^{\mathrm{a} \#}$ & $269 \pm 3.8^{\mathrm{a}^{*} \#}$ & $8.3 \pm 0.60$ \\
& & 8 & $19 \pm 1.3$ & $130 \pm 0.6^{\mathrm{a}}$ & $238 \pm 12.0^{\mathrm{a}}$ & $9.7 \pm 0.28$ \\
& Middle & 0 & $37 \pm 2.3^{* \#}$ & $130 \pm 6.4^{\mathrm{a}}$ & $256 \pm 8.5^{\mathrm{a}^{*}}$ & $9.4 \pm 0.27$ \\
& & 8 & $21 \pm 2.5$ & $128 \pm 3.7^{\mathrm{a}}$ & $231 \pm 0.4^{\mathrm{a}}$ & $9.6 \pm 0.01$ \\
& Lower & 0 & $37 \pm 5.4^{*}$ & $102 \pm 1.8^{\mathrm{b} \#}$ & $214 \pm 4.7^{\mathrm{b}^{*}}$ & $9.2 \pm 0.01^{\#}$ \\
& & 8 & $17 \pm 0.3$ & $105 \pm 1.3^{\mathrm{b \#}}$ & $196 \pm 2.3^{\mathrm{b}}$ & $9.3 \pm 0.01^{\#}$ \\
& Upper & 0 & $46 \pm 0.4^{*}$ & $119 \pm 5.9^{\mathrm{a}}$ & $235 \pm 1.1^{\mathrm{a}}$ & $7.8 \pm 0.78^{\mathrm{a}}$ \\
& & 8 & $21 \pm 4.6$ & $113 \pm 10.8^{\mathrm{a}}$ & $211 \pm 13.6^{\mathrm{a}}$ & $9.5 \pm 0.52^{\mathrm{a}}$ \\
& Middle & 0 & $45 \pm 0.5^{*}$ & $113 \pm 0.4^{\mathrm{a}}$ & $234 \pm 2.4^{\mathrm{a}}$ & $9.1 \pm 0.02^{\mathrm{ab}}$ \\
& & 8 & $17 \pm 1.8$ & $117 \pm 5.9^{\mathrm{a}}$ & $206 \pm 12.0^{\mathrm{a}}$ & $9.2 \pm 0.01^{\mathrm{b}}$ \\
& Lower & 0 & $32 \pm 7.1^{*}$ & $67 \pm 6.3^{\mathrm{b}}$ & $204 \pm 4.5^{\mathrm{b}}$ & $12.6 \pm 1.30^{\mathrm{b}}$ \\
& & 8 & $15 \pm 2.8$ & $64 \pm 1.5^{\mathrm{b}}$ & $180 \pm 11.4^{\mathrm{b}}$ & $12.8 \pm 0.97^{\mathrm{b}}$ \\
& Cultivar (C) & & 0.727 & $<0.001$ & $<0.001$ & 0.003 \\
& Stems (S) & & 0.004 & $<0.001$ & $<0.001$ & $<0.001$ \\
& Ensiling (E) & & $<0.001$ & 0.372 & $<0.001$ & 0.024 \\
& $\mathrm{C} \times \mathrm{S}$ & & 0.126 & 0.001 & 0.113 & $<0.001$ \\
& $\mathrm{C} \times \mathrm{E}$ & & 0.294 & 0.894 & 0.954 & 0.820 \\
& $\mathrm{~S} \times \mathrm{E}$ & & 0.199 & 0.282 & 0.638 & 0.047 \\
& $\mathrm{C} \times \mathrm{S} \times \mathrm{E}$ & & 0.090 & 0.493 & 0.636 & 0.905 \\
\hline
\end{tabular}

A1, gas production within $3 \mathrm{~h}$; A2, gas production between 3 and $20 \mathrm{~h}$; B2, time needed to reach half of A2; GP72, gas production within $72 \mathrm{~h}$.

Values with different superscript letters $(a, b)$ within cultivars of either fresh or silage samples are significantly $(P \leq 0.05)$ different. Values before ensiling indicated by * are significantly $(P \leq 0.05)$ different from values after ensiling. Values of stems of LG30211 indicated by \# are significantly $(P \leq$ 0.05) different from corresponding stems of MZP8057. 
CHAPTER 4

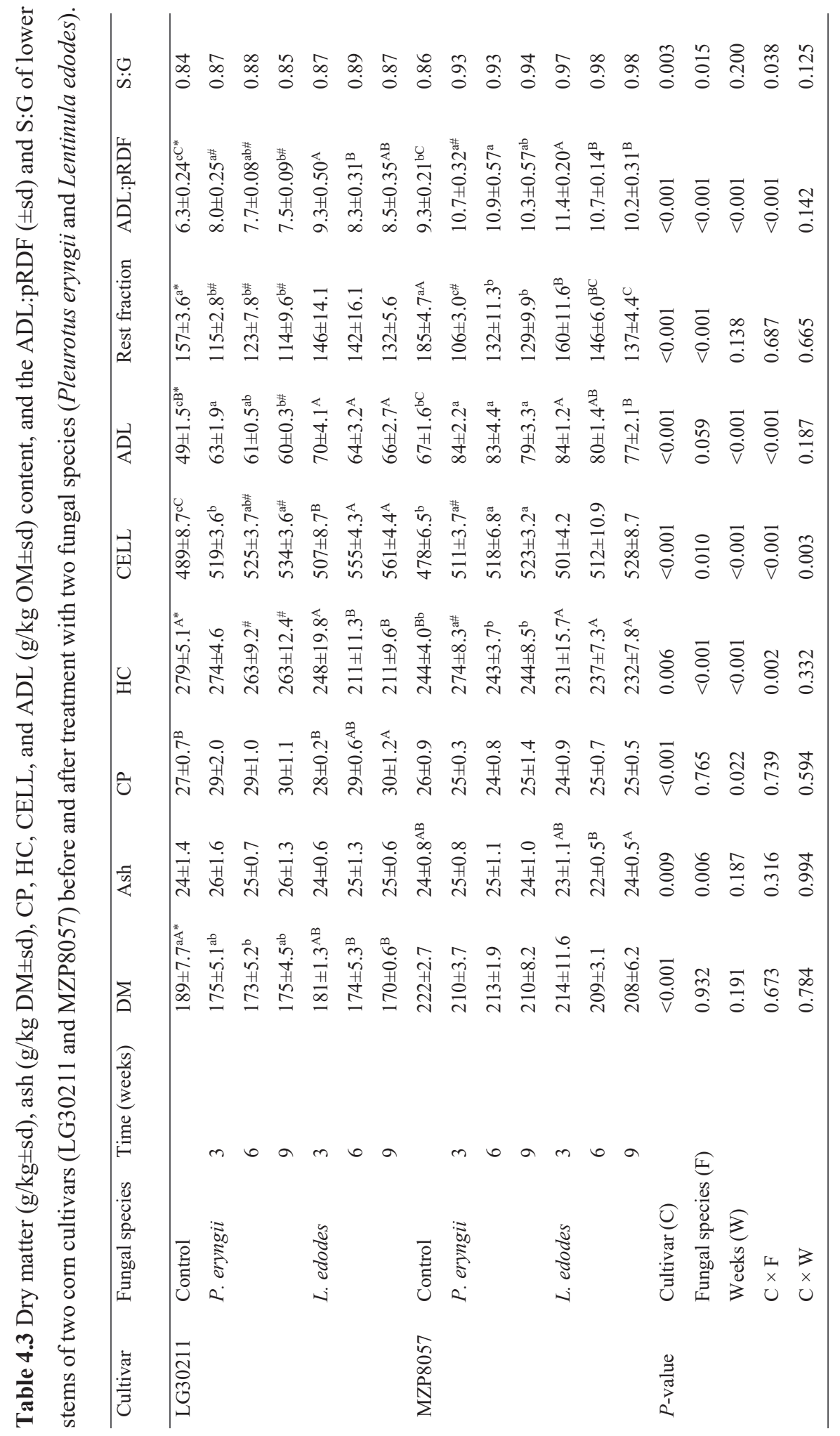


CHAPTER 4

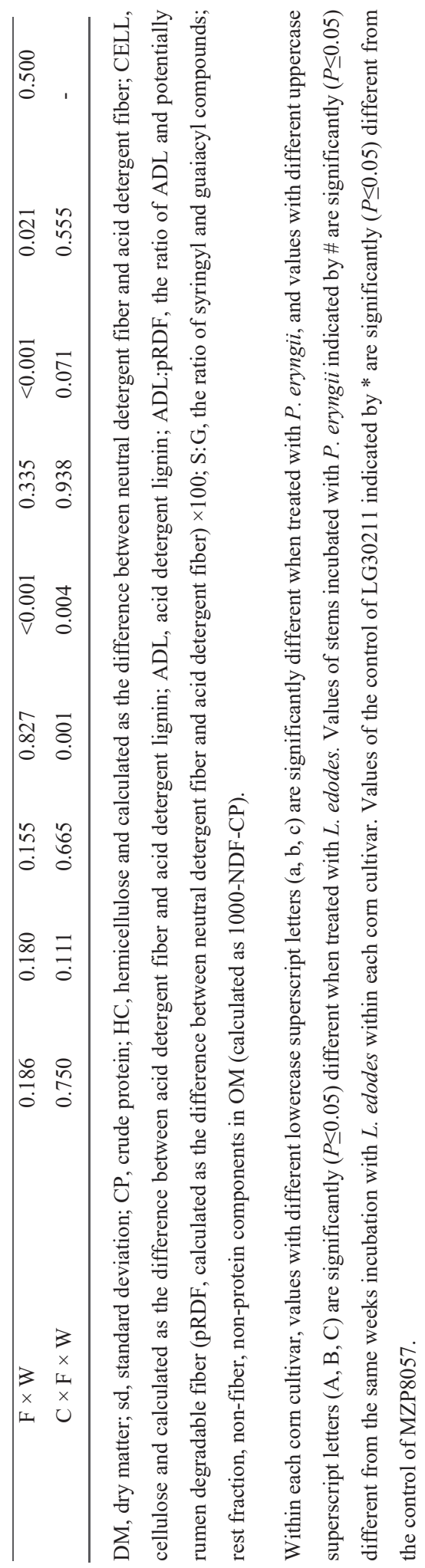


CHAPTER 4
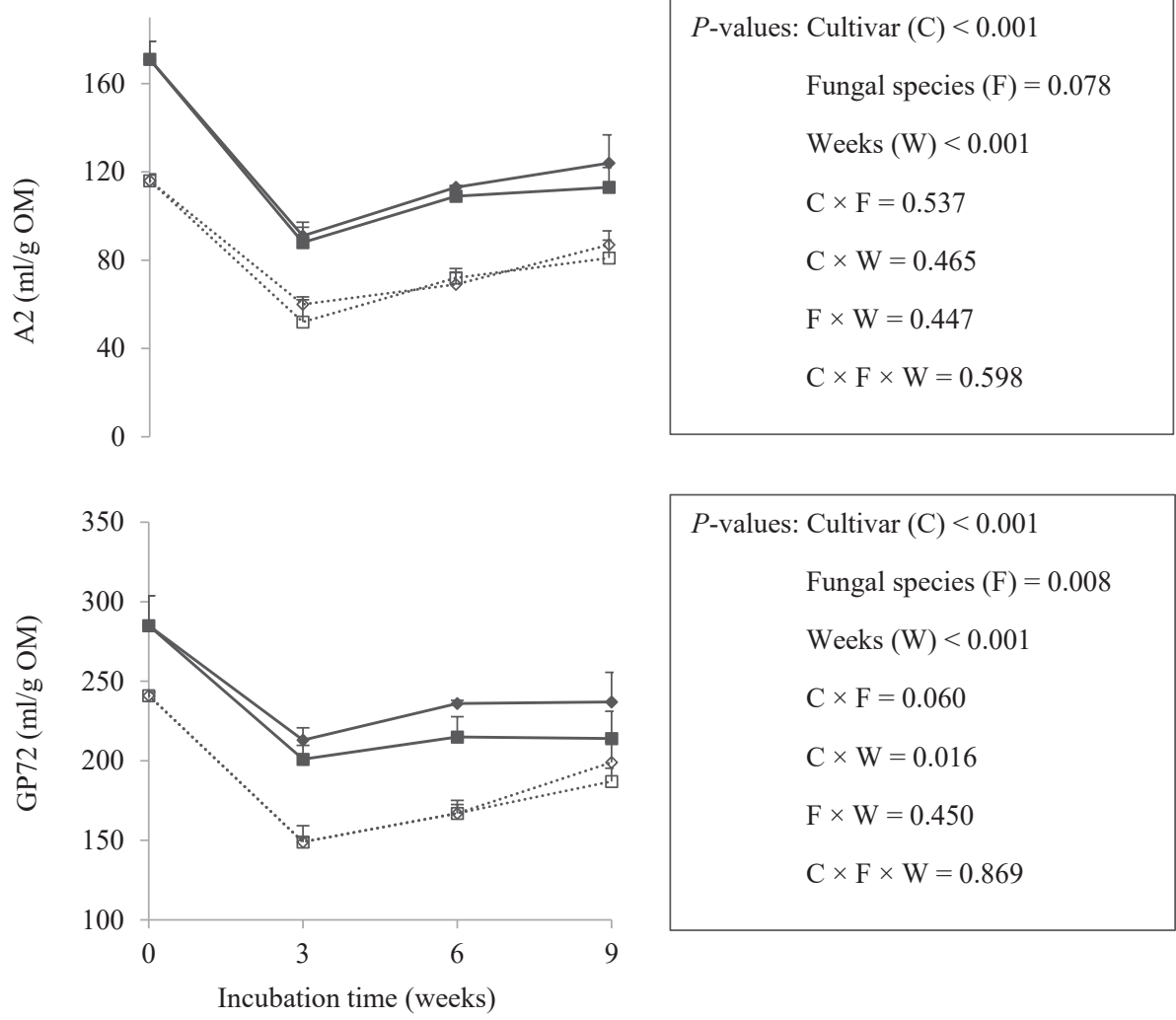

Figure 4.2 In vitro gas production ( $\mathrm{ml} / \mathrm{g} \mathrm{OM}$ ) between 3 and $20 \mathrm{~h}$ incubation (parameter A2) and within $72 \mathrm{~h}$ (GP72) of lower stems from two corn cultivars (LG30211 and MZP8057) treated with two fungal species (Pleurotus eryngii and Lentinula edodes) for 0, 3, 6 and 9 weeks.

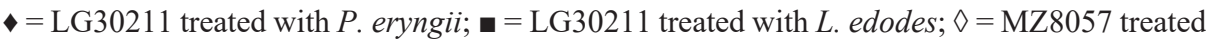
with P. eryngii; $\square=$ MZ8057 treated with L. edodes. Error bars represent standard deviations $(\mathrm{n}=3)$ with L. edodes.

\subsubsection{In vitro gas production of lower stem before and after fungal treatment}

The gas production between 3 and $20 \mathrm{~h}$ (A2) and GP72 of the lower stem of both corn cultivars decreased significantly in the first 3-weeks of treatment with both fungal species (Figure 4.2). For both cultivars, A2 and GP72 (the latter not with LG30211) were significantly higher after 9-weeks of treatment with both fungal species, compared 


\section{CHAPTER 4}

with 3-weeks of treatment. However, A2 and GP72 were highest for the untreated internodes for both cultivars. Only corn cultivar had a significant $(P=0.023)$ effect on B2.

\subsection{Discussion}

\subsubsection{Effect of ensiling on the stems}

Ensiling is commonly used to preserve forages for ruminants. Researchers have investigated the changes in chemical composition and nutrient degradability during ensiling of the whole corn plants (Cone et al., 2008; Der Bedrosian et al., 2012; Hallada et al., 2008; Kleinschmit and Kung Jr., 2006). However, there is little information on ensiling corn stems only. The present data indicate that the stem can be successfully ensiled and that the cell wall degradation of the stem is not influenced by ensiling, although gas production within $72 \mathrm{~h}$ decreased upon ensiling indicating a decline in OM degradation.

Briefly, the process of ensiling starts with the first phase that is characterized by the diminishing effect of $\mathrm{O}_{2}$ in the silo and is confined to a few hours. The second phase is the main fermentation phase which lasts for about 1 week but can be more than 1 month. During the second phase, the remaining water soluble carbohydrates are utilized by microorganisms and protein- $\mathrm{N}$ is converted to $\mathrm{NH}_{3}-\mathrm{N}$. With the development of heteroand homo-fermentative bacteria, VFA and lactic acid are produced and the $\mathrm{pH}$ declines. In order to investigate how the chemical composition changed during ensiling, the substrates were ensiled for 1, 2, 4 and 8 weeks and we expected the greatest changes to occur in the first weeks of ensiling and no change between 4 and 8 weeks. In our study, the $\mathrm{pH}$, the acetic acid concentration and the ammonia proportion were comparable to those of whole plant corn silages (Der Bedrosian et al., 2012; Herrmann et al., 2011; Yan et al., 2009a, 2009b) and tended to be constant after approximately 4 weeks of ensiling. Similarly, Santos and Kung Jr. (2016) reported that the $\mathrm{pH}$, the lactic acid, acetic acid, and ammonia concentration in whole plant corn silage did not change significantly after 45 days of storage. These findings are consistent with Der Bedrosian et al. (2012) who found that active fermentation only occurs for a relatively short time in the silos. Although many metabolic process remain active during long-term storage (Der Bedrosian et al., 2012), it seems that 4 weeks of storage is sufficient for the corn 
stem silage to enter the stable phase. However, Ward and de Ondarza (2008) suggested that whole plant corn silage requires at least 4 months for full fermentation. Besides, the stems of LG30211 showed a higher $\mathrm{pH}$ (on average 3.9 at 8 weeks) than MZP8057 (on average 3.6 at 8 weeks), and the $\mathrm{pH}$ of the lower stem was lower than that of the other parts, which was most likely because of the availability of metabolic water to support microbial growth, which is limited as moisture declines (Muck, 1990; Whiter and Kung Jr., 2001). This is in line with the observation that alfalfa silage with a higher DM content had greater pH (Santos and Kung Jr., 2016).

In our study, ensiling significantly decreased the DM content of the stems. In line with our results, Herrmann et al. (2011) reported that the DM content of whole plant corn silage decreased after ensiling in the laboratory glass silos. As the stems and the whole corn plants were ensiled in glass jars and no water can escape or enter the glass jars, the decreased DM content after ensiling was possibly due to the fermentation of water soluble carbohydrate and protein by the microorganisms. In contrast, Yan et al. (2009a, $2009 \mathrm{~b}$ ) found that the DM content of whole plant corn silage and corn stover silage sampled at different time points in the silos of dairy farms increased with prolonged storage time, which was ascribed to the leakage of fluid that contained low DM. As the water soluble carbohydrates and protein were fermented by the microorganisms, the concentrations of NDF, ADF, and ADL on an OM basis increased after ensiling. This finding with corn stems was opposite to previous studies where the NDF content in whole plant corn silage was not affected by the length of storage (Der Bedrosian et al., 2012; Sanderson, 1993) or significantly decreased after ensiling (Herrmann et al., 2011). The decreased NDF content observed by Herrmann et al. (2011) in whole plant corn silage was presumably due to the acid hydrolysis of hemicellulose (Morrison, 1979). Santos and Kung Jr. (2016) suggested that the action of hemicellulases, present in the original forage, determines whether the NDF content decreases or not. Collectively, the different effects of ensiling on the NDF content among studies may be attributable to the difference in experimental materials (corn stems versus whole plant corn silage), corn hybrids evaluated, or various additives used. Although the ADL content increased after ensiling in our study, this finding demonstrated that ADL was not hydrolyzed by the acids during ensiling, which agrees with previous studies (Morrison, 1979; Herrmann et al., 2011).

For LG30211, the CP content of the three parts of the stem differed, but not for 


\section{CHAPTER 4}

MZP8075. Although the fermentation of water soluble carbohydrates can lead to an increase of $\mathrm{CP}$ content after ensiling, the $\mathrm{CP}$ was also fermented by the microorganisms which may explain the unchanged CP content after 8 weeks ensiling.

The in vitro gas production technique was used to assess the degradability of the stems. Based on Cone et al. (1997), A1 is assumed to be caused by fermentation of water soluble carbohydrates. Upon ensiling, A1 significantly decreased, reflecting the utilization of water soluble carbohydrates by the microorganisms in the glass jars. Cone et al. (2008) also reported that the A1 of whole plant corn silage decreased after ensiling for 14 days. This is confirmed by Sanderson (1993) who reported that the water soluble carbohydrates declined to more than $50 \%$ of the original content in whole plant corn silage. The A2 is suggested to represent the degradation of non-soluble components, indicating the cell wall degradation in this case (Cone et al., 1997). As expected, the cell wall degradation of the stems was not influenced by ensiling. Hunt et al. (1993) showed that the NDF degradability of whole plant corn silage did not change after ensiling for 60 days. Der Bedrosian et al. (2012) found that NDF degradability of whole plant corn silage was not influenced by the length of storage up to 360 days. Cone et al. (2008) also reported that the length of storage did not affect the degradation of cell walls of whole plant corn silage. In contrast, Hallada et al. (2008) showed that the in situ NDF degradability of whole plant corn silage increased by $1.2 \%$ units per month from 1 to 330 days without reaching a plateau and Young et al. (2012) reported that NDF degradation increased after ensiling for 45 or 150 days with addition of exogenous protease enzymes. The reasons for the discrepancies among studies is unknown but may be caused by the methods used to evaluate NDF degradation, experimental materials, and corn hybrids. The total gas production within $72 \mathrm{~h}$ decreased upon ensiling, indicating a decline in OM degradation due to ensiling.

\subsubsection{Effect of fungal treatment on the stems}

As investigated in a previous study (He et al., 2018) and observed in the present study, the lignin content of the internodes increased from the top to the bottom, indicating the bottom part of the stem is the least degradable and impedes the degradation of the whole stem as fiber degradability is negatively correlated with lignin content (Arora and Sharma, 2009; Boon et al., 2005; Tuyen et al., 2012). It is also shown in the first 
experiment in the present study that the degradation of the lower part of the stem (as indicated by the smaller A2 and GP72 values for the lower part of the stem) is lower than that of the other parts of the stem. Hence, only the lower part of the stems was inoculated with fungi in the second experiment. Even though the lower parts of the stem from the two corn cultivars was used in both experiments, their chemical composition was somewhat different (Table 1 and 3). Before sterilization for the fungal treatment, the substrates were immersed in water for three days which may result in the removal of some water soluble compounds including free sugars, organic acids, and inorganic acids (Chen et al., 2007, 2010) from the lower stem. In line with this disappearance of some water soluble compounds, the concentration of fiber components of the lower stem in the second experiment was higher than that in the first experiment. In an earlier study, the lower parts of corn stems were treated with P. ostreatus and T. versicolor but no improvement of nutritive value was observed (Lynch et al., 2014). In the present study, L. edodes and P. eryngii were selected since L. edodes was shown to have high potential to degrade lignin and to improve the nutritive value of highly lignified agricultural by-products (Tuyen et al., 2013; Van Kuijk et al., 2015), and P. eryngii performed best in increasing OM degradation of corn stover (Tuyen et al., 2013).

The fungal treatment to degrade lignin in the stem can be separated into two phases. During the first phase, the relatively easily accessible components, including starch, pectin, and hemicellulose will be utilized by the fungi. In line with previous studies (Van Kuijk et al., 2015, 2016a, 2016b, 2017), the HC content in the substrates decreased after the fungal treatment likely because $\mathrm{HC}$ was used as an energy source by the fungi. However, the decreased HC content was not observed when the MZP8057 was treated with $P$. eryngii for 3 weeks in the current study. It is unclear why the HC content of MZP8057 increased after treatment with $P$. eryngii, but it might be due to the utilization of relatively easily accessible components other than $\mathrm{HC}$ during the first few weeks. With the partial removal of these easily accessible components, that can also be fermented by the rumen microorganisms, A2 and GP72 (indicating the degradation of cell wall and OM, respectively) of the lower stem treated with fungi for 3 weeks were expected to decrease. Indeed, significantly lesser values of A2 and GP72 after 3 weeks of incubation with fungi compared with untreated stems were observed. The concentration of $\mathrm{ADL}$ and CELL increased due to the utilization of other components in the substrates by fungi. Compared with the untreated stems, the stems treated with 


\section{CHAPTER 4}

fungi for 3 weeks showed a higher S:G. The change of S:G can be the result of lignin degradation. Van Kuijk et al. $(2015,2016 a, 2017)$ found that the ADL content in wheat straw decreased after 2 weeks treatment with L. edodes or C. subvermispora. In our study, three weeks was used as the interval to investigate the effects of the fungal treatment on the chemical compositions and in vitro gas production parameters, so it is uncertain at which week the delignification phase started. However, the wheat straw used in previous studies (Van Kuijk et al., 2015, 2016a, 2017) was higher in ADL and lower in $\mathrm{HC}$ content than the lower corn stem used in the present study, indicating that it may take longer before the fungi start to degrade lignin in the corn stem. It seems that the change in lignin composition during the first three weeks may not be the result of lignin degradation. Martinez et al. (2005) reported that even though the lignin degrading enzymes cannot enter the intact cell walls during the initial phase of fungal delignification, the radicals can still attack lignin in the first phase. These radicals did not prefer to degrade S- or G-units in the substrates (Van Kuijk et al., 2016a). It is possible that the G-units are easily accessible to these radicals, which results in an increase of the $S: G$ in the first 3 weeks.

The second phase is known as the delignification phase during which the lignin is degraded and the degradability of the substrates increases. When the lower stem of the two corn cultivars were treated with two fungi for 6 or 9 weeks, only a slight, nonsignificant decrease in the ADL content was observed. However, compared with untreated samples, the ADL content was higher after the fungal treatment. Since the ADL content is reported to be negatively correlated with forage degradation in the rumen (Arora and Sharma, 2009; Boon et al., 2005; Tuyen et al., 2012), it is reasonable that both A2 and GP72 of the substrates were lower after the fungal treatment.

After fungal treatment with L. edodes for 9 weeks, CP content in LG30211 increased which may be explained by the relative degradation of HC by fungi. Similarly, Van Kuijk et al. (2015) observed that CP content in wheat straw, miscanthus and wood chips increased after treatment with L. edodes and P. ostreatus for 12 weeks. However, it is also reported that $\mathrm{CP}$ content in miscanthus and wood chips did not change after treatment with L. edodes for 2 and 4 weeks (Van Kuijk et al., 2015), which is similar with our results that CP content in MZP8075 was constant after treatment with both fungal species, and that CP content in LG30211 did not change after treatment with $P$. eryngii. 
CHAPTER 4

In the current study, the two selected fungi did not improve the nutritional value of the lower corn stem. Compared with wheat straw and wood chips, the lower stem contains less ADL and more HC (Van Kuijk et al., 2016a). When the wheat straw and wood chips are treated with fungi, the fungi have to degrade lignin in order to access the more easily degradable carbohydrates. Since the HC content in the lower stem was higher compared with wheat straw and woodchips, the fungi could utilize the $\mathrm{HC}$ in the lower stem relatively easily, resulting in higher ADL content and reduced degradation of the stem after fungal treatment as indicated by smaller A2 values.

\subsection{Conclusion}

Both ensiling and fungal treatment by $L$. edodes and P. eryngii did not improve the degradation of the lower corn stem of the two cultivars. During the ensiling and the fungal treatment, the change in chemical compositions was mainly derived from the utilization of water soluble carbohydrates by microorganisms and the degradation of $\mathrm{HC}$ by the fungi, respectively.

\subsection{Acknowledgements}

We thank Sino-Dutch Dairy Development Centre (SDDDC) for their financial support. Appreciation is extended to John van der Lippe, Lei Mao, Eli Ratni, Jing Tang, and Marcel Visser (Wageningen University \& Research) for assistance with corn harvesting and preparation for fungal treatment.

\subsection{References}

Anastacio, G.M., Benito, A.P., Octavio, A.C.O., Angelica, E.O., Carlos, M.A.J., 2009. Urea treated maize straw for small-scale dairy systems in the highlands of central Mexico. Trop. Anim. Health Prod. 41, 1487-1494.

Arora, D.S., Sharma, R., 2009. Enhancement in in vitro digestibility of wheat straw obtained from different geographical regions during solid state fermentation by white rot fungi. Bioresources 4, 909-920. 


\section{CHAPTER 4}

Boon, E.J.M.C., Engels, F.M., Struik, P.C., Cone, J.W., 2005. Stem characteristics of two forage maize (Zea mays L.) cultivars varying in whole plant digestibility. II. Relation between in vitro rumen fermentation characteristics and anatomical and chemical features within a single internode. Netherlands J. Agric. Sci.-Wageningen J. Life Sci. 53, 87-109.

Chen, S.F., Mowery, R.A., Scarlata, C.J., Chambliss, C.K., 2007. Compositional analysis of water-soluble materials in corn stover. J. Agric. Food Chem. 55, 5912-5918.

Chen, S.F., Mowery, R.A., Sevcik, R.S., Scarlata, C.J., Chambliss, C.K., 2010. Compositional analysis of water-soluble materials in switchgrass. J. Agric. Food Chem. 58, 3251-3258.

Cone, J.W., Van Gelder, A.H., Visscher, G.J.W., Oudshoorn, L., 1996. Use of a new automated time related gas production apparatus to study the influence of substrate concentration and source of rumen fluid on fermentation kinetics. Anim. Feed Sci. Technol. 61, 113-128.

Cone, J.W., Van Gelder, A.H., Driehuis, F., 1997. Description of gas production profiles with a three-phasic model. Anim. Feed Sci. Technol. 66, 31-45.

Cone, J.W., Van Gelder, A.H., Van Schoten, H.A., Groten, J.A.M., 2008. Effects of chop length and ensiling period of forage maize on in vitro rumen fermentation characteristics. Netherlands J. Agric. Sci.-Wageningen J. Life Sci. 55, 155-166.

Der Bedrosian, M.C., Nestor, Jr. K., Kung, Jr. L., 2012. The effects of hybrid, maturity, and length of storage on the composition and nutritive value of corn silage. J. Dairy Sci. $95,5115-5126$.

Ding, S.Y., Liu, Y.S., Zeng, Y.N., Himmel, M.E., Baker, J.O., Bayer, E.A., 2012. How does plant cell wall nanoscale architecture correlate with enzymatic digestibility? Science 338, 1055-1060.

Groot, J.C.J., Cone, J.W., Williams, B.A., Debersaques, F.M.A., Lantinga, E.A., 1996. Multiphasic analysis of gas production kinetics for in vitro fermentation of ruminant feeds. Anim. Feed Sci. Technol. 64, 77-89.

Hallada, C.M., Sapienza, D.A., Taysom, D., 2008. Effect of length of time ensiled on dry matter, starch and fiber digestibility in whole plant corn silage. J. Dairy Sci. 91 (E- 
Suppl.), 30 (Abstr.).

He, Y., Mouthier, T.M.B., Kabel, M.A., Dijkstra, J., Hendriks, W.H., Struik, P.C., Cone, J.W., 2018. Lignin composition is more important than content for maize stem cell wall degradation. J. Sci. Food Agric. 98, 384-390.

Hendriks, A.T.W.M., Zeeman, G., 2009. Pretreatments to enhance the digestibility of lignocellulosic biomass. Bioresour. Technol. 100, 10-18.

Herrmann, C., Heiermann, M., Idler, C., 2011. Effects of ensiling, silage additives and storage period on methane formation of biogas crops. Bioresour. Technol. 102, 5153 5161.

Hunt, C.W., Kezar, W., Hinman, D.D., Combs, J.J., Loesche, J.A., Moen, T., 1993. Effects of hybrids and ensiling with and without a microbial inoculant on the nutritional characteristics of whole-plant corn. J. Anim. Sci. 71, 38-43.

Jalc, D., 2002. Straw enrichment for fodder production by fungi. In: Kempken, F. (Ed.), The Mycota XI, Agricultural Application. Berlin Springer-Verlag, pp. 19-38.

Jami, E., Shterzer, N., Yosef, E., Nikbachat, M., Miron, J., Mizrahi, I., 2014. Effects of including $\mathrm{NaOH}$-treated corn straw as a substitute for wheat hay in the ration of lactating cows on performance, digestibility, and rumen microbial profile. J. Dairy Sci. 97, 1623-1633.

Jeffries, T.W., 1994. Biodegradation of lignin and hemicelluloses. In: Ratledge, C. (Ed.), Biochemistry of microbial degradation. Dordrecht Kluwer, pp. 233-277.

Jurak, E., Punt, A.M., Arts, W., Kabel, M.A., Gruppen, H., 2015. Fate of carbohydrates and lignin during composting and mycelium growth of Agaricus bisporus on wheat straw based compost. PLoS One 10.1371, 1-16.

Kleinschmit, D.H., Kung, Jr. L., 2006. The effects of Lactobacillus buchneri 40788 and Pediococcus pentosaceus R1094 on the fermentation of corn silage. J. Dairy Sci. 89, 3999-4004.

Lynch, J.P., O’Kiely, P., Murphy, R., Doyle, E.M., 2014. Changes in chemical composition and digestibility of three maize stover components digested by white-rot fungi. J. Anim. Physiol. Anim. Nutr. 98, 731-738. 


\section{CHAPTER 4}

Martinez, A.T., Speranza, M., Ruiz-Duenas, F.J., Ferreira, P., Camarero, S., Guillen, F., Martinez, M.J., Gutierrez, A., Del Rio, J.C., 2005. Biodegradation of lignocellulosics: microbial, chemical, and enzymatic aspects of the fungal attack of lignin. Int. Microbiol. 8, 195-204.

Morrison, I.M., 1979. Changes in the cell wall components of laboratory silages and the effect of various additives on these changes. J. Agric. Sci. 93, 581-586.

Muck, R.E., 1990. Dry matter level effects on alfalfa silage quality. II. Fermentation products and starch hydrolysis. Trans. ASAE. 33, 373-381.

Ralph, J., Hatfield, R.D., 1991. Pyrolysis-GC-MS characterization of forage materials. J. Agric. Food Chem. 39, 1426-1437.

Sanderson, M.A., 1993. Aerobic stability and in vitro fiber digestibility of microbially inoculated corn and sorghum silage. J. Anim. Sci. 71, 505-514.

Santos, M.C., Kung, Jr. L., 2016. Short communication: The effects of dry matter and length of storage on the composition and nutritive value of alfalfa silage. J. Dairy Sci. $99,1-4$.

Scheiner, D., 1976. Determination of ammonia and Kjeldahl nitrogen by indophenol method. Water Res. 10, 31-36.

Susmel, P., Stefanon, B., 1993. Aspects of lignin degradation by rumen microorganisms. J. Biotechnol. 30, 141-148.

Tang, S.X., Gan, J., Sheng, L.X., Tan, Z.L., Tayo, G.O., Sun, Z.H., Wang, M., Ren, G.P., 2008. Morphological fractions, chemical composition and in vitro fermentation characteristics of maize stover of five genotypes. Anim. 2, 1772-1779.

Taweel, H.Z., Tas, B.M., Smit, H.J., Elgersma, A., Dijkstra, J., Tamminga, S., 2005. Effects of feeding perennial ryegrass with an elevated concentration of water-soluble carbohydrates on intake, rumen function and performance of dairy cows. Anim. Feed Sci. Technol. 121, 243-256.

Tuyen, V.D., Cone, J.W., Baars, J.J.P., Sonnenberg, A.S.M., Hendriks, W.H., 2012. Fungal strain and incubation period affect chemical composition and nutrient availability of wheat straw for rumen fermentation. Bioresour. Technol. 111, 336-342. 
Tuyen, V.D., Phuong, H.N., Cone, J.W., Baars, J.J.P., Sonnenberg, A.S.M., Hendriks, W.H., 2013. Effect of fungal treatments of fibrous agricultural by-products on chemical composition and in vitro rumen fermentation and methane production. Bioresour. Technol. 129, 256-263.

Vanholme, R., Demedts, B., Morreel, K., Ralph, J., Boerjan, W., 2010. Lignin biosynthesis and structure. Plant Physiol. 153, 895-905.

Van Kuijk, S.J.A., Sonnenberg, A.S.M., Baars, J.J.P., Hendriks, W.H., Cone, J.W., 2015. Fungal treatment of lignocellulosic biomass: importance of fungal species, colonization and time on chemical composition and in vitro rumen degradability. Anim. Feed Sci. Technol. 209, 40-50.

Van Kuijk, S.J.A., Del Rio, J.C., Rencoret, J., Gutierrez, A., Sonnenberg, A.S.M., Baars, J.J.P., Hendriks, W.H., Cone, J.W., 2016a. Selective ligninolysis of wheat straw and wood chips by the white-rot fungus Lentinula edodes and its influence on in vitro rumen degradability. J. Anim. Sci. Biotechnol. 7, 55-68.

Van Kuijk, S.J.A., Sonnenberg, A., Baars, J.J.P., Hendriks, W.H., Cone, J.W., 2016b. The effect of adding urea, manganese and linoleic acid to wheat straw and wood chips on lignin degradation by fungi and subsequent in vitro rumen degradation. Anim. Feed Sci. Technol. 213, 22-28.

Van Kuijk, S.J.A., Sonnenberg, A.S.M., Baars, J.J.P., Hendriks, W.H., Del Rio, J.C., Rencoret, J., Gutierrez, A., De Ruijter, N.C.A., Cone, J.W., 2017. Chemical changes and increased degradability of wheat straw and oak wood chips treated with the white rot fungi Ceriporiopsis subvermispora and Lentinula edodes. Biomass Bioenergy 105, 381-391.

Van Soest, P.J., McQueen, R.W., 1973. The chemistry and estimation of fiber. Proc. Nutr. Soc. 32, 123-130.

Van Soest, P.J., Robertson, J.B., Lewis, B.A., 1991. Methods for dietary fiber, neutral detergent fiber, and nonstarch polysaccharides in relation to animal nutrition. J. Dairy Sci. 74, 3583-3597.

Verbic, J., Stekar, J.M.A., Resnik-Cepon, M., 1995. Rumen degradation characteristics and fiber composition of various morphological parts of different maize hybrids and 


\section{CHAPTER 4}

possible consequences for breeding. Anim. Feed Sci. Technol. 54, 133-148.

Ward, R.T., de Ondarza, M.B., 2008. Effect of month of sample submittal on corn silage nutrient fractions, starch availability, NDF digestibility, and fermentation profiles measured at a commercial forage-testing laboratory. J. Dairy Sci. 91 (Suppl 1), 30 (Abstr.).

Whiter, A.G., Kung, Jr. L., 2001. The effect of a dry or liquid application of Lactobacillus plantarum MTD1 on the fermentation of alfalfa silage. J. Dairy Sci. 84, 2195-2202.

Yan, J., Wang, W., Gao, Y., Mu, S., 2009a. Variation law of corn straw silage nutritional quality in different storage periods. Acta. Agric. Boreali-occidentalis Sinica. $18,57-60$.

Yan, J., Wang, W., Gao, Y., Mu, S., 2009b. Variation law of whole-plant corn silage nutritional quality under different storage periods. J. Northwest A. F. Univ. (Nat. Sci. Ed.). 37, 75-80.

Yang, L., Gao, Y., 2016. Bottlenecks of efficient utilization of corn straw feed and its solutions. J. Jilin Agri. Univ. 38, 634-638.

Young, K.M., Lim, J.M., Der Bedrosian, M.C., Kung, Jr. L., 2012. Effect of exogenous protease enzymes on the fermentation and nutritive value of corn silage. J. Dairy Sci. 95, 6687-6694.

Zuo, X., Wang, H., Wang, Y., Wang, L., Jing, L., Wang, D., 2015. Estimation and suitability evaluation of corn straw resources in China. Chinese J. Agri. Resour. Reg. Plaan. 36, 5-10. 
Supplementary information for:

The nutritional value of the lower corn stem cannot be improved by ensiling nor by a fungal treatment

Yuan He, Jan Dijkstra, Anton S.M. Sonnenberg, Thibaut M.B. Mouthier, Mirjam A. Kabel, Wouter H. Hendriks, John W. Cone 
CHAPTER 4

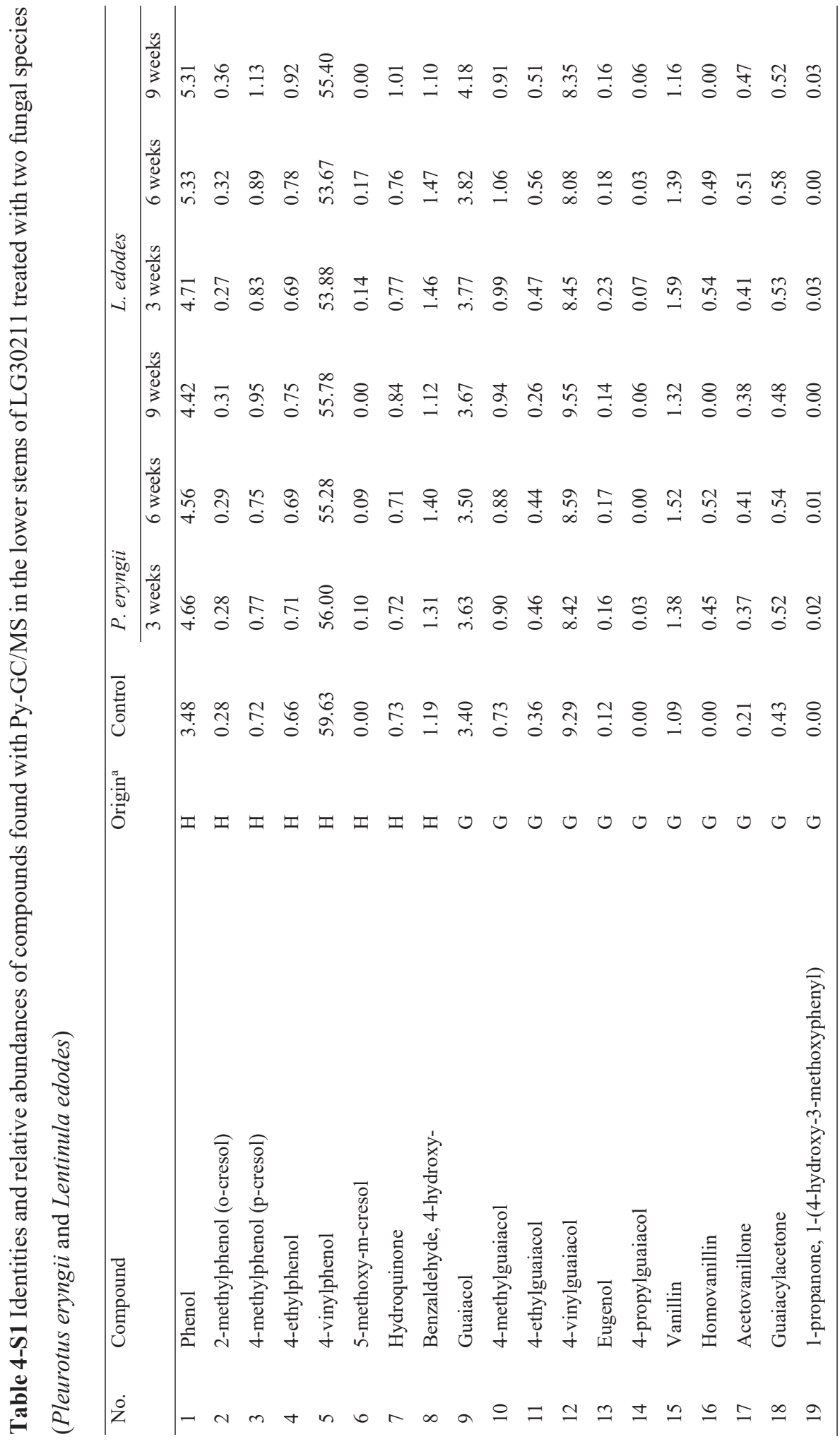


CHAPTER 4

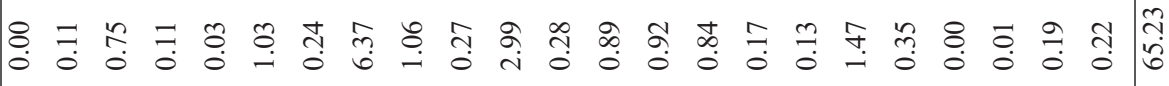

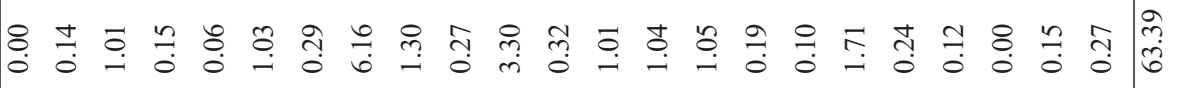

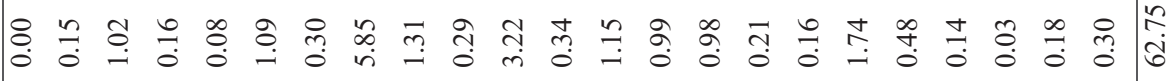

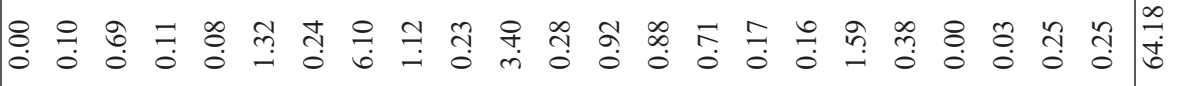

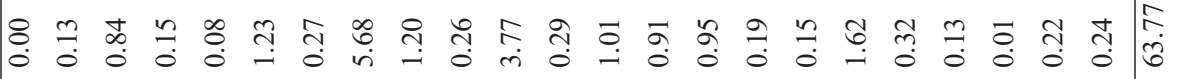

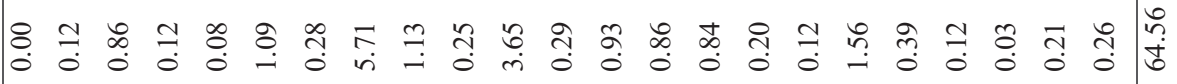

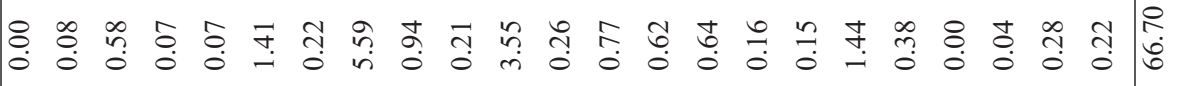

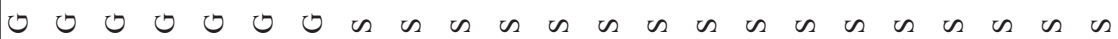

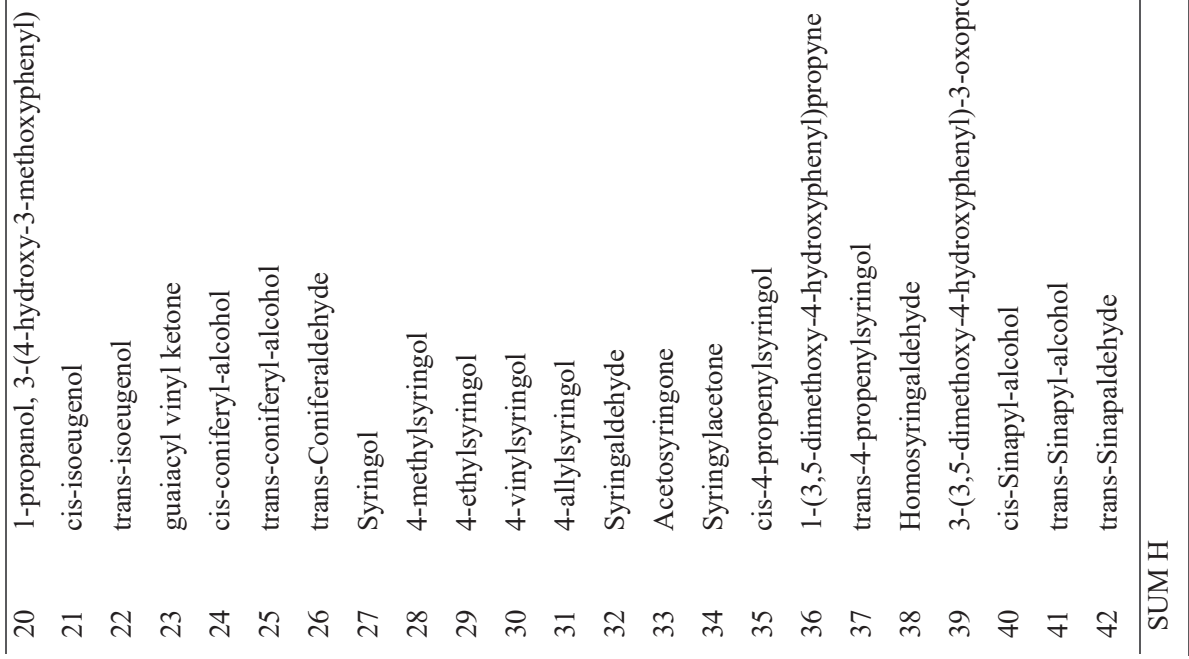




\section{CHAPTER 4}

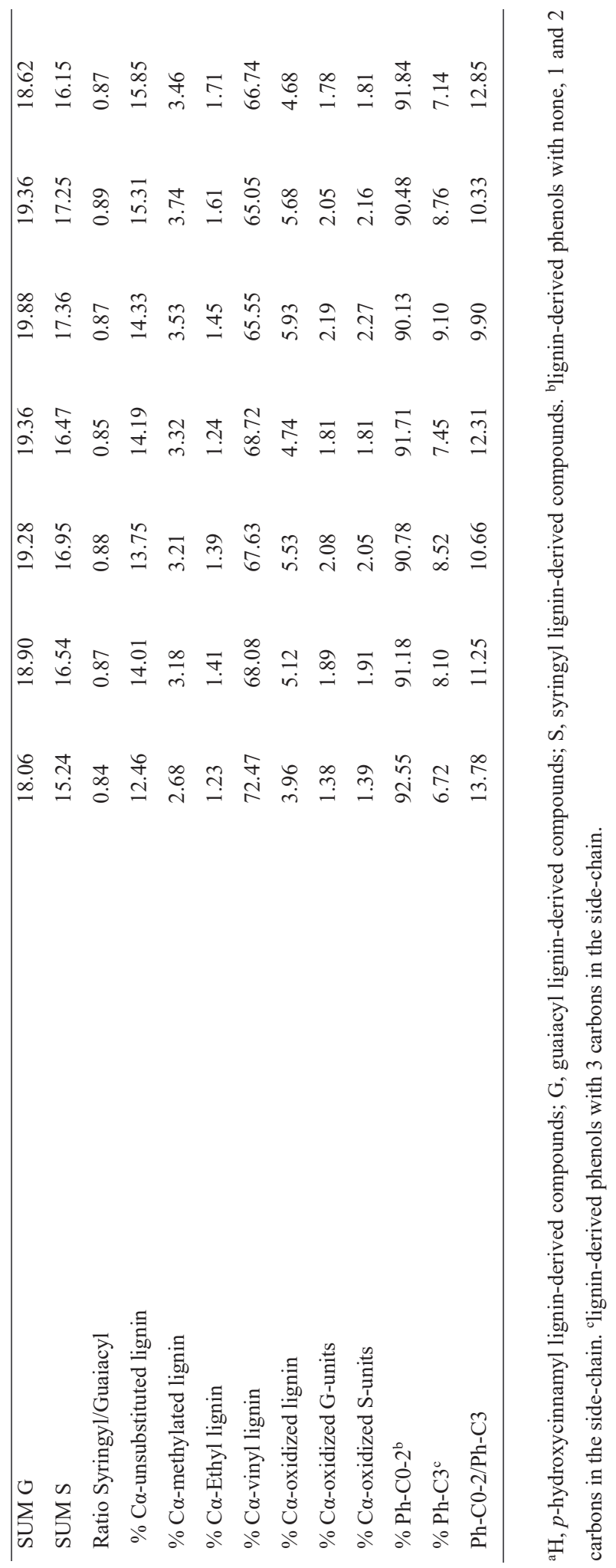


CHAPTER 4

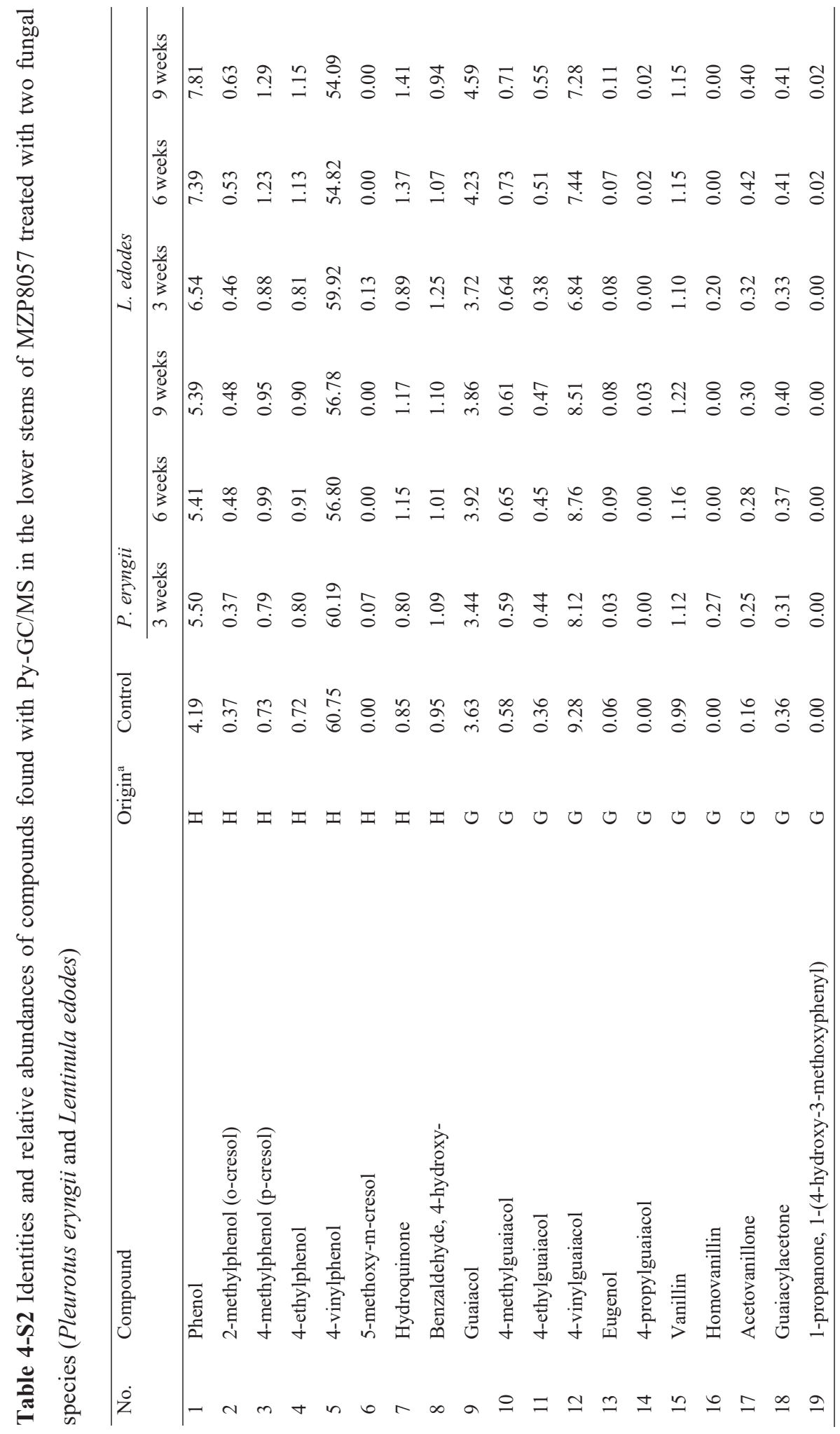




\section{CHAPTER 4}

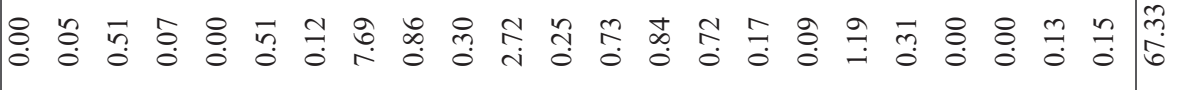

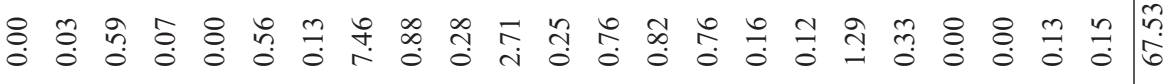

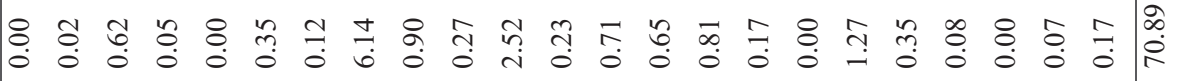

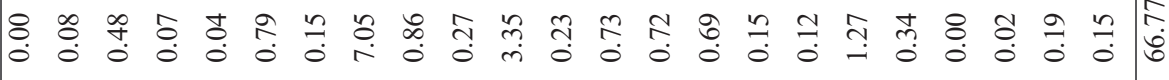

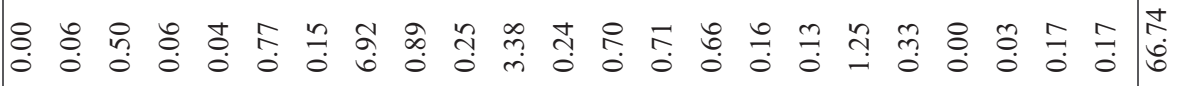

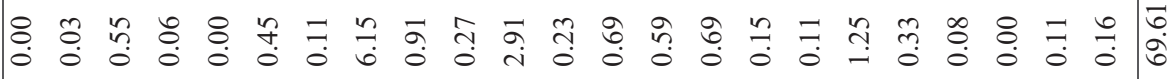

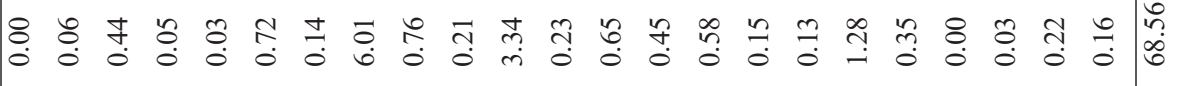

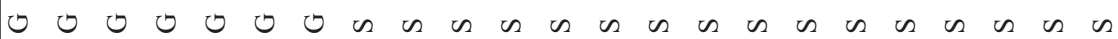

窟

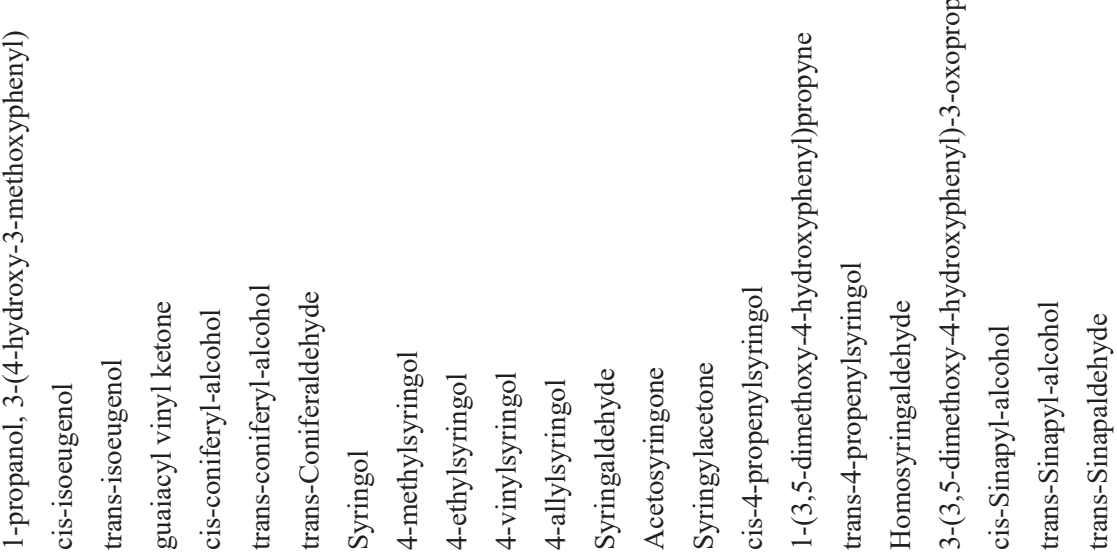

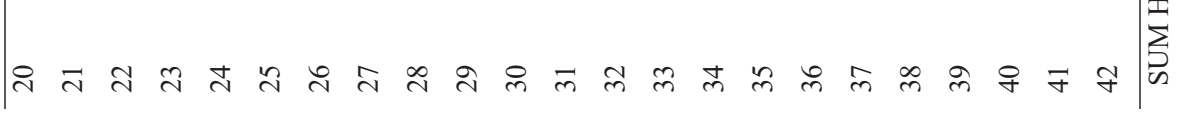


CHAPTER 4

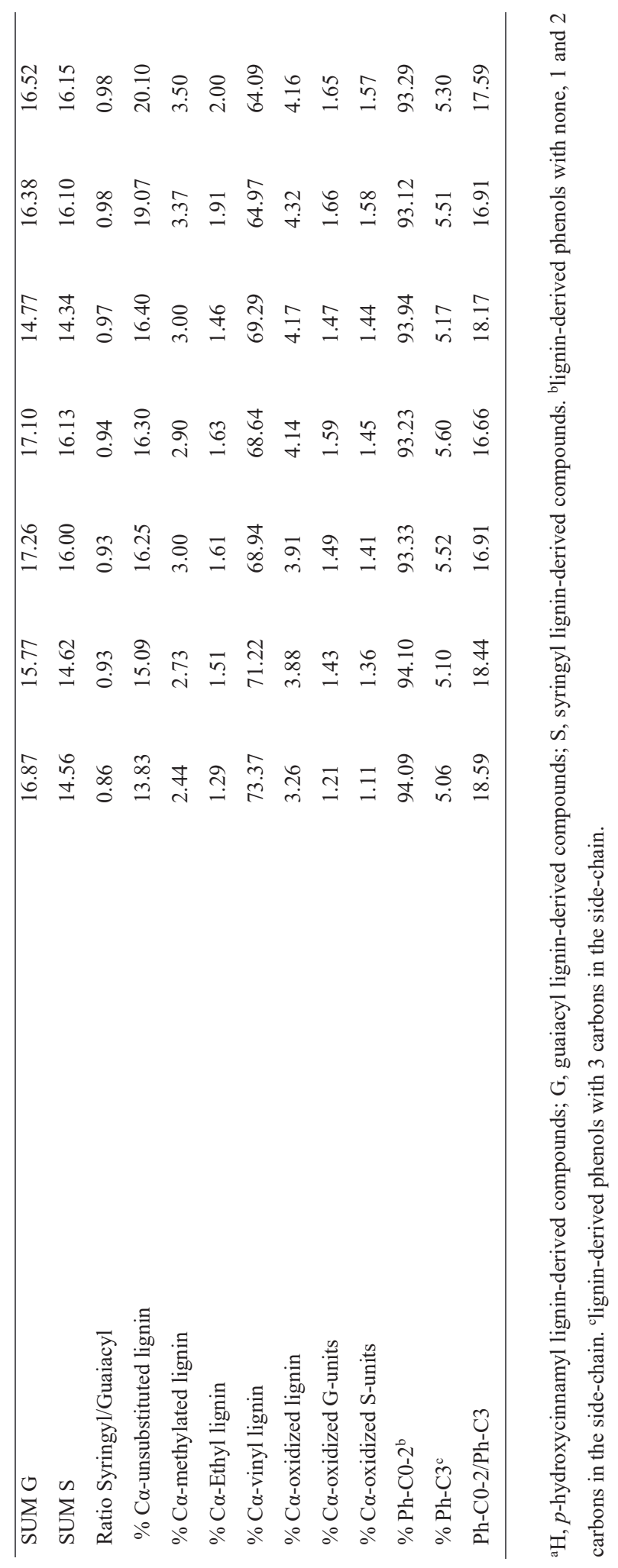




\section{Chapter 5}

\section{Corn stover usage and farm profit for sustainable dairy farming in China}

Yuan He, John W. Cone, Wouter H. Hendriks, Jan Dijkstra

Animal Nutrition Group, Wageningen University \& Research, De Elst 1, 6708 WD Wageningen, the Netherlands

Submitted to Asian-Australasian Journal of Animal Sciences 


\section{CHAPTER 5}

\section{Abstract}

Corn plants can be harvested for whole plant corn silage (WPCS) or corn stover (stems and leaves) silage (CSS), with the latter saving corn grain for other purposes, including human consumption. The optimal ratio of WPCS to CSS (WPCS:CSS) to reach the greatest profit of dairy farmers and its consequences with respect to corn grain available for other purposes, land use efficiency, enteric methane production and milk nitrogen $(\mathrm{N})$ efficiency was simulated using an optimization model at milk production levels of 0, 10, 20 and $30 \mathrm{~kg} / \mathrm{cow} / \mathrm{d}$. Corn plants from 4 different cultivars were collected and ensiled as WPCS and CSS and their nutritional value, including chemical composition, rumen undegradable protein and metabolizable energy (ME), was determined to provide data for the model.

Within each milk production level, the dry matter intake (DMI) of cows increased with more CSS included in the ration until the neutral detergent fiber in the ration reached a level at which the DMI decreased with a continuous decreasing WPCS:CSS ratio. The optimal WPCS:CSS ratio (DM basis) to maximize the profit of dairy farmers at production levels of $0,10,20$ and $30 \mathrm{~kg}$ milk/cow/d was 16:84, 22:78, 44:56 and 88:12, respectively, with increasing proportions of WPCS and soybean meal included in the diet at higher milk production levels. The land area needed to grow corn plants was 4.54, 31.41, 33.43 and 30.25 ha, respectively. The amount of corn available $(\mathrm{Mg}$ $\mathrm{DM} / \mathrm{ha} / \mathrm{yr}$ ) for other purposes saved from this land area decreased with an increased milk production level. However, compared with the dairy farms with high producing cows (30 kg/d milk), more farms with low producing cows $(10 \mathrm{~kg} / \mathrm{d}$ milk) and therefore more land area to grow corn and soybeans were needed to achieve the same total amount of milk production. Extra land is available to grow corn when the milk production was high, leading to an increased amount of corn available for other purposes. The quality of CSS influenced the land area required to grow corn plants, the profit of dairy farmers, and corn available for other purposes, with the corn variety that had a high ME content decreasing the land area required, increasing the profit of dairy farms and providing more corn available for other purposes, than the low ME corn variety. The price of CSS and ground corn had effects on the profit of both dairy farmers and arable farmers. For high producing cows, at the optimal WPCS:CSS the enteric methane production was greater, but the methane production per $\mathrm{kg}$ milk was lower, compared with low producing cows. Similarly, milk N efficiency was greater for the 
high producing cows, compared with low producing cows.

The optimal WPCS:CSS for dairy farms to maximize their profit increases with decreased milk production levels. However, at a fixed total amount of milk being produced, more corn will be available for other purposes including human consumption, with high producing cows. At the optimal WPCS:CSS ratio for each milk production level, methane emission intensity is smaller, and milk $\mathrm{N}$ efficiency is greater, with high producing cows compared with low producing cows, which may alleviate the environment pollution related to dairy production.

Keywords: profit, dairy farm, corn stover silage, whole plant corn silage 


\section{CHAPTER 5}

\subsection{Introduction}

In recent years, the profit of dairy farms in China decreased due to the lower price of raw milk and higher price of commonly used feedstuffs, such as ground corn (GC), soybean meal (SBM), and high quality forages (Li et al., 2018; Shi et al., 2015). Since feed costs are the greatest component of total operating expenses on most dairy farms (Buza et al., 2014), reducing feed costs would be an effective method to improve the profit of dairy farms. Utilization of crop residues may help dairy farmers to reduce feed costs (Shi et al., 2015).

The land area used to grow corn plants in China in 2014 has been estimated to be more than $3 \times 10^{7}$ hectares (Fan and Shi, 2014), making corn an important economic crop for China. Whole plant corn silage (WPCS) is widely used in dairy farms globally (Khan et al., 2015). Corn stover silage (CSS), the silage of the stems and leaves obtained after harvesting the ears from the plants, is rarely included in a ration of high producing cows (Wang et al., 2014), due to its greater neutral detergent fiber (NDF) and acid detergent lignin (ADL) content and lower degradability, leading to a lower net energy (NE) content compared with WPCS (Shi et al., 2015). Since low producing and dry cows require less energy than high producing cows, it may be possible to include CSS as a major forage source in the ration of low energy demanding cows without compromising their productive performance. More information on the proper ratio of the plants used for WPCS to those used for CSS (WPCS:CSS) will enable dairy farmers to make better decisions during the harvest of corn plants based on the production level at their farms. In addition, the chemical composition and ruminal degradability of WPCS and CSS differs among corn cultivars (Tolera et al., 1999; Verbic et al., 1995) and as such it is of interest to evaluate the influence of corn cultivars on the profit of dairy farms.

According to the Food and Agriculture Organization (FAO) of the United Unions, the global human population will increase to approximately 9.5 billion by 2050 , and as a result $70 \%$ to $100 \%$ more food is required compared to the current demand (Godfray et al., 2010). Due to the activities of rumen microbes, dairy cows can convert low quality forages, which is inedible for humans, into high quality human edible food (milk and meat). Corn grain is an important starch source in the ration of dairy cows (Akins et al., 2012), which is also a high quality food for humans. In light of the increased demand for food, more corn grain should be utilized as a food source. As such, increased utilization 


\section{CHAPTER 5}

of CSS, instead of WPCS, in dairy rations would contribute to future food security. Currently it is unknown which proportion of corn plants may be harvested and used as CSS to maximize profit of dairy farms at different cow production levels, and consequently how much corn grain can be saved and be available for other purposes. Increasing food security, however, is likely to affect efficiency of production as replacing starch with fiber in dairy cattle diets may affect enteric methane production (Van Gastelen et al., 2015) and milk nitrogen (N) efficiency (Cantalapiedra-Hijar et al., 2014), two important parameters of sustainability.

The objectives of this study were to determine the optimal WPCS:CSS to maximize the profit of dairy farms, and to analyze how much corn grain can be used for other purposes, with varying WPCS:CSS and varying milk production level, as well as to evaluate the consequences for enteric methane production and milk $\mathrm{N}$ efficiency.

\subsection{Materials and Methods}

\subsubsection{Corn harvesting and ensiling}

Corn plants from 4 different cultivars were collected and ensiled as WPCS and CSS and their nutritional value, including chemical composition, rumen undegradable protein (RUP) and metabolizable energy (ME), was determined, to provide data required for optimization of the model. Whole corn plants of 2 cultivars (Lg30248 and Perley) were harvested from a trial field with a sandy soil of Limagrain (Rilland, the Netherlands) in Wouw (the Netherlands) on September 2016, and another 2 cultivars (Rivaldinio and Leovoxx) were harvested from the experimental fields with a sandy soil of Unifarm in Wageningen (the Netherlands). All plants were cut at $10 \mathrm{~cm}$ above the ground. After harvesting, the ears of 5 plants per cultivar were separated from the leaves and stems (stover). Five whole plants as well as the five stovers were chopped into 1 to $2 \mathrm{~cm}$ pieces and ensiled in triplicate in 0.51 clamp lid glass jars (IKEA, Leiden, the Netherlands) per cultivar. Each jar was filled with approximately $300 \mathrm{~g}$ (wet weight) whole plant or $200 \mathrm{~g}$ (wet weight) corn stover without a headspace. For Lg30248 and Perley, no molasses or lactic acid bacteria were added unlike Rivaldinio and Leovoxx. The application rate of molasses was $1 \%$ of the fresh forage weight (Huisden et al., 2009), and $0.758 \mathrm{~g}$ Lactobacillus plantarum (Volac International Ltd., Royston, UK) was mixed with 2.51 distilled water and $10 \mathrm{ml}$ of the solution was applied to $1 \mathrm{~kg}$ fresh forage. The jars were 


\section{CHAPTER 5}

stored at room temperature $\left(\sim 20^{\circ} \mathrm{C}\right)$ for 8 weeks. After ensiling, the samples were taken out of the glass jars and stored at $-20^{\circ} \mathrm{C}$ in plastic bags.

The samples were thawed at room temperature and separated into two portions. Thirty $g$ of each sample was weighed into a stomacher bag, diluted with $270 \mathrm{ml}$ distilled water and mixed vigorously for $5 \mathrm{~min}$, where after the fluid was used to determine $\mathrm{pH}$ and ammonia$\mathrm{N}$. The remained was oven-dried at $70^{\circ} \mathrm{C}$ for $72 \mathrm{~h}$ and ground to pass a $1 \mathrm{~mm}$ sieve using a Peppink 100 AN cross-beater mill (Peppink, Deventer, The Netherlands) and stored in a plastic bottle until chemical analysis and in vitro gas production (IVGP).

\subsubsection{Chemical analysis}

After the samples were mixed with distilled water as described above, the $\mathrm{pH}$ of the fluid was measured immediately using a pH meter (Hanna Instruments pH 300GLP, Amorim Povoa de Varzim, Portugal). Thirty $\mathrm{ml}$ of the fluid was centrifuged at $25,000 \times \mathrm{g}$ for 10 min, and the supernatant $(1.5 \mathrm{ml})$ was collected and acidified with equal volumes of trichloroacetic acid for ammonia analysis. Ammonia-N was determined by a colorimetric method, as described by Scheiner (1976).

Dry matter (DM) content was determined gravimetrically after $4 \mathrm{~h}$ heating at $103{ }^{\circ} \mathrm{C}$ in an oven and ash content after combustion for $3 \mathrm{~h}$ at $550{ }^{\circ} \mathrm{C}$ in a muffle furnace. Ether extract (EE) content was determined using a Foss Soxtec 2050 (Foss, Hilleroed, Denmark), after extraction with petroleum ether. Neutral detergent fiber was determined by the method of Van Soest et al. (1991), using a heat-resistant amylase. Acid detergent fiber (ADF) and ADL were determined using the method of Van Soest and McQueen (1973). Nitrogen was determined by the Kjeldahl method and crude protein (CP) was calculated as $\mathrm{N} \times 6.25$. Nitrogen was determined in the NDF and ADF residues to calculate the neutral detergent insoluble nitrogen (NDIN) and acid detergent insoluble nitrogen (ADIN), as well as the CP in NDF (NDICP) and ADF (ADICP).

\subsubsection{In vitro gas production}

The IVGP technique was performed to determine the amount of ME (Menke et al., 1979) and RUP (Cone et al., 2009) of WPCS and CSS. Rumen fluid was collected $2 \mathrm{~h}$ after the morning feeding from three non-lactating rumen fistulated cows fed a grass silage based 


\section{CHAPTER 5}

diet twice daily. The rumen fluid was pooled, stored in warm insulated flasks, pre-filled with $\mathrm{CO}_{2}$ and filtered through 2 layers of cheesecloth.

For the ME prediction, the rumen fluid was mixed with an anaerobic buffer/mineral solution as described by Menke et al. (1979) under continuous flushing with $\mathrm{CO}_{2}$. A carefully weighed amount of DM (400 mg) of the ground samples was incubated in 60 $\mathrm{ml}$ buffered rumen fluid (one part of rumen fluid and two parts of buffer) in $250 \mathrm{ml}$ bottles at $39{ }^{\circ} \mathrm{C}$ in a shaking water bath. Each sample was run in one bottle each time and two runs were performed during separate weeks. Gas production was recorded for $24 \mathrm{~h}$ using an automated system (Cone et al., 1997).

For RUP prediction, 1 part of the rumen fluid was mixed with 19 parts of a N-free anaerobic buffer/mineral solution (Cone et al., 2009) under continuous flushing with $\mathrm{CO}_{2}$. Ten g/l rapidly fermentable carbohydrates (3.33 g/l glucose (Merck 8337, Merck, Darmstadt, Germany), 3.33 g/l xylose (X1500, Sigma-Aldrich, Darmstadt, Germany) and $3.33 \mathrm{~g} / \mathrm{l}$ soluble starch (Merck 1252, Merck, Darmstadt, Germany)) were added to the buffered rumen fluid and incubated at $39^{\circ} \mathrm{C}$ for $4 \mathrm{~h}$ in a 51 bottle with continuous flushing of $\mathrm{CO}_{2}$. After $4 \mathrm{~h}$ incubation, $60 \mathrm{ml}$ of the buffered rumen fluid was added with a dispenser to bottles which contained exactly $15 \mathrm{mg} \mathrm{N}$ originating from the sample. Each sample was run in one bottle each time and two runs were performed during separate weeks. Gas production was recorded for $48 \mathrm{~h}$ with an automated system (Cone et al., 1997).

The equations used to predict the ME and RUP contents of the silage samples were described by Menke et al. (1979) and Cone et al. (2009), respectively.

\subsubsection{Model development}

A reference dairy farm was defined with 100 dairy cows, 305 days lactation and 60 days dry period. The mature weight of the cows was assumed to be $650 \mathrm{~kg}$ (NRC, 2001). The average $\mathrm{CP}$, crude fat and lactose content in the milk was assumed to be $3.22 \%$ (Dairy Association of China, 2017), 3.81\% (Dairy Association of China, 2017) and 4.85\% (NRC, 2001), respectively. It was further assumed that the cows had no net gain or loss of body weight and were not pregnant. A simple ration, consisting of GC, SBM and forages (WPCS and CSS) was formulated to calculate the feed costs using the income over feed 


\section{CHAPTER 5}

costs principle (Bailey and Ishler, 2007) and to meet the NE and metabolizable protein (MP) requirements of the cows according to the NRC (2001). The energy contents (digestible energy, ME and NE) of the feedstuffs which were used in the model, were derived from NRC (2001) based on their chemical composition and total NE requirement of the cows. The chemical composition of GC and SBM were also obtained from the NRC (2001), while the chemical composition of CSS and WPCS were determined as described above since the RUP of WPCS (with DM content being 39.2\% and 39.7\%) and CSS were not reported by the NRC (2001). The fermentation parameters and chemical composition of WPCS and CSS of the 4 corn cultivars are shown in Table 5.1 and the average values were used in the model. The digestibility of the RUP of WPCS and CSS was predicted by the equations described by Givens et al. (2004). The yield of microbial CP (MCP) was calculated as $0.130 \times$ discounted total digestible nutrients $(T D N)$ when rumen degradable protein (RDP) intake exceeded $1.18 \times \mathrm{TDN}$-predicted MCP; otherwise, the yield of MCP was calculated as $0.85 \times \mathrm{RDP}$ intake (NRC, 2001). The MCP was assumed to contain $80 \%$ true protein and the true protein was assumed to be $80 \%$ digestible (NRC, 2001). Except RUP and MCP, endogenous CP (ECP) also contributed to MP and the conversion of ECP to MP was $40 \%$ based on the NRC (2001). To maintain a healthy rumen environment, the minimum amount of NDF included in the ration of the cows was set at $25 \%$ of the feed intake (NRC, 2001). The maximum amount of NDF was set according to Mertens (1994), with a maximum amount of NDF included in the ration of cows producing 0, 10, 20 and $30 \mathrm{~kg}$ milk daily of $60 \%, 53 \%, 45 \%$ and $37 \%$, respectively, beyond which the dry matter intake (DMI) is depressed. Based on the NE and MP requirements of the dairy cows and the nutrients provided by the feedstuffs, together with the prices of the feedstuffs and the costs to make silage, the least cost ration can be formulated at different WPCS:CSS ratios.

In the present analysis, the profit of dairy farmers was defined as the difference between the income (selling raw milk) and the feed costs. The average price of raw milk was taken to be $3.45 \mathrm{RMB} / \mathrm{kg}$ (Liu, 2016). The dairy farmers bought GC and SBM from the market and whole plant corn and corn stover from arable farmers, and then made WPCS and CSS at the farms. Since the objective of this model was to evaluate whether the profit of dairy farmers changed with decreasing WPCS:CSS, which had no influence on the salaries, electricity, other fixed costs, etc., only the costs related to the feedstuffs and silage making (machine, cover film, molasses and lactic acid bacteria) were considered. The price of GC and SBM was assumed to be 2.37 and $3.38 \mathrm{RMB} / \mathrm{kg}$ fresh weight, respectively (Liu, 
2016). The price of corn stover was assumed to be $50 \mathrm{RMB} / \mathrm{Mg}$ forage (fresh weight), due to its low nutritional value. The price of corn grain sold by the arable farmers was arbitrarily set at $60 \%$ of the price of ground corn bought at the market. The price of whole plant corn sold by the arable farmer was calculated based on the profit of selling corn grain and corn stover and the ratio of corn stover to whole plant corn (assumed to be 0.41 ) and corn grain to corn stover (assumed to be 1.11) on DM basis (Verbic et al., 1995) to make the profit of arable farmers (RMB/ha/yr) constant with different WPCS:CSS ratios. In this case, the price of whole corn plants was $325 \mathrm{RMB} / \mathrm{Mg}$ forage (fresh weight). Mechanical processing (Der Bedrosian et al., 2012; Khan et al., 2015) is a commonly used procedure during whole corn plants harvesting, which can decrease the proportion of intact corn kernels present in WPCS and improve the total tract starch digestibility (Johnson et al., 2002). Therefore, when the plants were harvested and ensiled as WPCS, the costs for the machinery to harvest whole plants was assumed to be greater, and the machine used to harvest corn plants as WPCS and CSS was assumed to cost 1500 and $1000 \mathrm{RMB} /$ hectare, respectively. The price of the cover film was set at $2.4 \mathrm{RMB} / \mathrm{m}^{2}$. For simplicity, the bunker silo was assumed to be cubic requiring three surfaces to be covered by the film. The surface of the silo was calculated based on the silo volume, which was related to the weight and density of the silage. The weight of the silages was calculated according to the daily intake, number of cows and days. The density of WPCS (Amours and Savoie, 2005) and CSS (Shinners et al., 2007) was 232 and $140 \mathrm{~kg} \mathrm{DM} / \mathrm{m}^{3}$, respectively. The application rate of molasses was $1 \%$ of fresh forage weight (Huisden et al., 2009) and $0.758 \mathrm{~g}$ L. plantarum (Volac International Ltd., Royston, UK) was mixed with 2.51 distilled water and applied to $250 \mathrm{~kg}$ forage. The price of molasses and $L$. plantarum was set at $900 \mathrm{RMB} / \mathrm{Mg}$ and $2500 \mathrm{RMB} / \mathrm{kg}$, respectively.

In the present analysis, the profit of arable farmers was defined as the difference between their income (selling whole plant corn and/or corn stover and corn grain separately when the plants were harvested as CSS, all mentioned above) and the costs to grow the corn plants and to collect the corn grain from the ear. According to the National Development and Reform Commission (2017), the average costs, including labor, land, fertilizer etc. to grow corn plants is $12415 \mathrm{RMB} / \mathrm{ha}$. After harvest, the arable farmers could sell the corn grain to feed or food companies to be further processed such as drying and grinding while the dairy farmer receives the corn stover. It was assumed that the cost to separate the corn grain from one ear by a machine is $0.01 \mathrm{RMB}$. 
CHAPTER 5

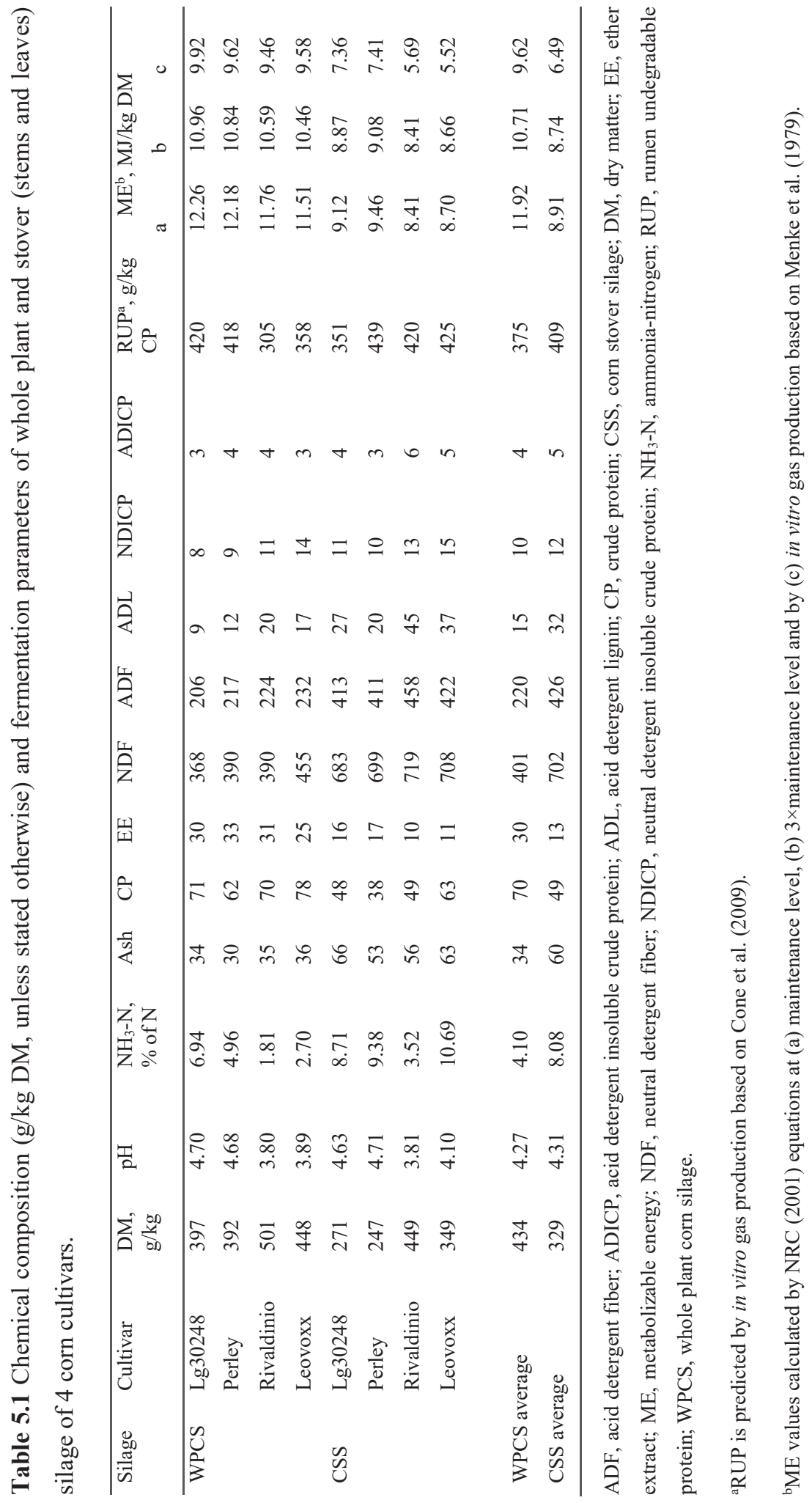


The weight of the corn stover of one plant was taken to be $0.0859 \mathrm{~kg}$ on DM basis (He et al., unpublished). Due to the fluid leakage (Yan et al., 2009) and microbial fermentation during ensiling (Kristensen et al., 2010), the DM loss was reported to be $10 \%$ for WPCS (Kohler et al., 2013) and it was assumed that this was also applicable for the CSS.

For each cow production level, the non-linear Generalized Reduced Gradient (GRG) of the Solver program in Excel was used to calculate diet composition to obtain the maximum profit of the dairy farmer whilst adhering to nutritional constraints. The total amount of WPCS and CSS required was calculated based on the daily intake of one dairy cow, the number of total cows at the farm and lactating days. The number of plants needed for this amount of WPCS and CSS was derived from the data (DM loss during ensiling and DM production of whole plant corn and corn stover) as described above. The total weight of corn grain, which was produced from the plants needed to make the CSS, was calculated according to the ratio of the weight of corn grain to corn stover on DM basis. The corn available for other purposes referred to the corn grain which was potentially available for human consumption or animal feed, and was assumed to be the difference between the corn grain harvested when the plants were used as CSS and corn grain (ground corn) purchased from the market.

The sowing density of corn plants was $10 / \mathrm{m}^{2}$, with $13.3 \mathrm{~cm}$ between plants and $75 \mathrm{~cm}$ between the rows (He et al., 2018), which was used to calculate the total land area required to grow corn plants. The soybean yield was $2.76 \mathrm{Mg} / \mathrm{ha}$ (FAO, 2017) and $78.7 \%$ of the soybean can be soybean meal (Dei, 2011) with a DM content being 89.5\% (NRC, 2001). To investigate the effect of the different milk production levels on the total corn available for other purposes comprehensively, an annual milk production was set at $915 \mathrm{Mg}$ (being the total amount of milk of 1 farm with 100 cows producing $30 \mathrm{~kg} / \mathrm{d}$ for 305 days) to calculate the number of cows needed, land area needed to grow corn and soybean for the dairy farms, extra land used to grow corn, and total corn available for other purposes. Land area to grow corn plants and soybean was calculated based on the ration to reach the highest profit of dairy farms, the number of cows, the lactating days and the yield of whole plant corn, corn stover and soybean meal. Corn grain available for other purposes, originating from the land area to grow corn plants for the dairy farms, was calculated as the amount of corn grain harvested when the corn plants are used as CSS, minus corn grain purchased from the market. The total land area needed to grow corn plants and soybean for the three milk production levels of cows to achieve the annual milk 


\section{CHAPTER 5}

production of $915 \mathrm{Mg}$ was calculated. Extra land area relative to the total land area required at a $10 \mathrm{~kg} / \mathrm{d}$ milk production level was calculated, and this extra land area was assumed to be used to grow corn plants, which will become available for other purposes. The total corn available for other purposes was the sum of the corn grain saved from the land needed to grow corn plants for dairy farms and corn grown on the extra land.

The enteric methane production was calculated based on the diet composition and the assumption that the enteric methane value of WPCS, CSS, GC and SBM was 17.5, 17.0, 19.7 and $20.5 \mathrm{~g}$ methane $\left(\mathrm{CH}_{4}\right) / \mathrm{kg}$ DM, respectively (Bannink et al., 2008; Vellinga et al., 2013). Milk $\mathrm{N}$ efficiency was calculated as $\mathrm{N}$ in milk divided by $\mathrm{N}$ intake.

\subsubsection{Sensitivity analysis}

The sensitivity of the model to changes in parameters related to the nutritional value of the forages and the price of the feedstuffs was investigated. Two corn cultivars with the highest and lowest predicted ME content (using NRC (2001) equations) of CSS (Perley and Rivaldinio, respectively) were selected to test the model sensitivity. Since the price of ground corn varies during the year, the highest and lowest price (year 2015) were used in the sensitivity analysis. The price of corn stover was set at $\pm 20 \%$ of the model value to evaluate sensitivity.

\subsection{Results}

The diet composition for dry cows and for lactating cows producing 10, 20 and $30 \mathrm{~kg}$ milk per day during 305 lactating days, when $0,25,50,75$ and $100 \%$ of plants were used to produce CSS is shown in Table 5.2. Cows producing more milk had a greater DMI and greater proportion of GC and SBM in the diet. Within a milk production level, upon increasing the CSS proportion of the diet, the DMI initially increased and then decreased. When all the plants were used to make CSS, GC was included in the diets for all the cows. Corn plants and land area required, annual profit of both dairy farmers and arable farmers and corn available for other purposes, for 100 dry cows during the 60 days dry period and 100 lactating cows at different production levels during 305 lactating days when 0, 25\%, $50 \%, 75 \%$ and $100 \%$ of plants are used as CSS, are shown in Table 5.3. More plants were needed when more CSS was included in the diets, given the lower nutritional value of 
CHAPTER 5

Table 5.2 Diet composition for dry cows and lactating cows (10, 20 and $30 \mathrm{~kg} / \mathrm{d})$ when fed various ratios of whole plant corn silage (WPCS) and corn stover silage (CSS).

\begin{tabular}{|c|c|c|c|c|c|c|}
\hline \multirow{2}{*}{$\begin{array}{l}\text { Milk yield, } \\
\mathrm{kg} / \mathrm{d}\end{array}$} & \multirow[t]{2}{*}{ WPCS:CSS } & \multirow[t]{2}{*}{ DMI, kg/d } & \multicolumn{4}{|c|}{ Diet composition,$\%$} \\
\hline & & & WPCS & CSS & $\mathrm{GC}$ & SBM \\
\hline \multirow[t]{5}{*}{$0^{\mathrm{b}}$} & 100:0 & 6.3 & 100.0 & 0 & 0 & 0 \\
\hline & $75: 25$ & 6.5 & 88.0 & 12.0 & 0 & 0 \\
\hline & $50: 50$ & 6.7 & 70.8 & 29.0 & 0 & 0.2 \\
\hline & $25: 75$ & 7.1 & 44.4 & 54.6 & 0 & 1.0 \\
\hline & $0: 100$ & 7.1 & 0 & 83.2 & 15.5 & 1.3 \\
\hline \multirow[t]{5}{*}{$10^{c}$} & 100:0 & 10.6 & 90.8 & 0 & 0 & 9.2 \\
\hline & $75: 25$ & 10.8 & 79.7 & 10.9 & 0 & 9.4 \\
\hline & $50: 50$ & 11.1 & 64.1 & 26.3 & 0 & 9.6 \\
\hline & $25: 75$ & 11.6 & 40.3 & 49.6 & 0 & 10.1 \\
\hline & $0: 100$ & 11.4 & 0 & 71.6 & 18.3 & 10.1 \\
\hline \multirow[t]{5}{*}{$20^{\mathrm{d}}$} & 100:0 & 15.2 & 87.0 & 0 & 0 & 13.0 \\
\hline & $75: 25$ & 15.5 & 76.4 & 10.4 & 0 & 13.2 \\
\hline & $50: 50$ & 15.9 & 61.4 & 25.2 & 0 & 13.4 \\
\hline & $25: 75$ & 15.7 & 33.7 & 41.4 & 11.4 & 13.5 \\
\hline & $0: 100$ & 15.4 & 0 & 58.4 & 28.1 & 13.5 \\
\hline \multirow[t]{5}{*}{$30^{\mathrm{e}}$} & 100:0 & 20.3 & 85.4 & 0 & 0 & 14.6 \\
\hline & $75: 25$ & 20.3 & 70.6 & 9.6 & 5.1 & 14.7 \\
\hline & $50: 50$ & 20.1 & 49.5 & 20.3 & 15.5 & 14.7 \\
\hline & $25: 75$ & 19.8 & 26.1 & 32.1 & 27.1 & 14.7 \\
\hline & $0: 100$ & 19.6 & 0 & 45.2 & 40.1 & 14.7 \\
\hline
\end{tabular}

DMI, dry matter intake; GC, ground corn; SBM, soybean meal.

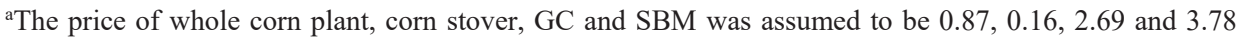
$\mathrm{RMB} / \mathrm{kg} \mathrm{DM}$, respectively.

${ }^{\text {b}}$ The optimal WPCS:CSS ratio is $16: 84$ to reach the greatest DMI $(7.3 \mathrm{~kg} / \mathrm{d})$.

${ }^{\mathrm{c}}$ The optimal WPCS:CSS ratio is $22: 78$ to reach the greatest DMI $(11.7 \mathrm{~kg} / \mathrm{d})$.

${ }^{\mathrm{d}}$ The optimal WPCS:CSS ratio is 44:56 to reach the greatest DMI $(16.0 \mathrm{~kg} / \mathrm{d})$.

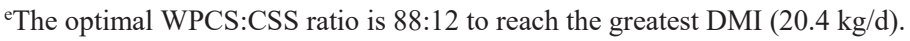




\section{CHAPTER 5}

CSS compared with WPCS. The profit of dairy farmers initially increased and then (at the point where GC was included in the diet) decreased with the increased WPCS:CSS ratio. To reach the greatest profit of dairy farmers, the optimal WPCS:CSS ratio increased with greater milk production levels, with optimal WPCS:CSS ratios ranging from 16:84 for dry cows to $88: 12$ for cattle producing $30 \mathrm{~kg}$ milk daily. The annual profit of arable farmers increased with decreasing WPCS:CSS. More corn (Mg DM/ha/yr) is available for other purposes if more plants were used as CSS in the diets of cows, and the amount of corn grain thus decreased with elevated milk production levels.

The number of cows needed to achieve $915 \mathrm{Mg} / \mathrm{yr}$ milk production (being the total amount of milk of 1 farm with 100 cows producing $30 \mathrm{~kg} / \mathrm{d}$ for $305 \mathrm{~d}$ ), land area needed to grow corn and soybean for the dairy farms under different milk production levels, and total corn available for other purposes, are shown in Table 5.4. To achieve the same milk production with 100 cows producing $30 \mathrm{~kg}$ milk daily for 305 days, 150 and 300 cows are required at production levels of 20 and $10 \mathrm{~kg} / \mathrm{d}$, respectively. Corn available for other purposes from the land needed to grow corn for feed decreased with the increased milk production level. To achieve the same amount of milk production, more land area was needed to grow corn plants and soybean for feed with cows producing less milk daily, and to produce $915 \mathrm{Mg}$ milk/yr at a production level of $10 \mathrm{~kg} / \mathrm{d}, 205.6 \mathrm{ha}$ is required. Compared with production levels of $10 \mathrm{~kg} / \mathrm{d}, 49.3$ and 72.7 ha land was available for other purposes with milk production levels of 20 and $30 \mathrm{~kg} / \mathrm{d}$, respectively. Assuming that this 49.3 and 72.7 ha land was also used to grow corn plants, the total corn available for other purposes was highest at a milk production of $30 \mathrm{~kg} / \mathrm{d}$, followed by a milk production of $20 \mathrm{~kg} / \mathrm{d}$, and with the lowest amount of corn available for other purposes at production levels of $10 \mathrm{~kg} / \mathrm{d}$.

The enteric methane production and milk $\mathrm{N}$ efficiency of cows producing 10, 20 and 30 $\mathrm{kg}$ milk daily are shown in Table 5.5. The methane production $(\mathrm{g} / \mathrm{d})$, methane intensity ( $\mathrm{g} / \mathrm{kg}$ milk) and $\mathrm{N}$ intake of cows were highest, and the $\mathrm{N}$ efficiency was lowest, when the WPCS:CSS was optimal to reach the highest profit of the dairy farms at each milk production level. Upon an increase in milk production level from 10 to $30 \mathrm{~kg} / \mathrm{d}$, daily methane production of cows increased (from 205 to $365 \mathrm{~g} / \mathrm{d}$ ) while methane intensity decreased (from 20.5 to $12.2 \mathrm{~g} / \mathrm{kg}$ ). The cows with higher milk production had a higher milk $\mathrm{N}$ efficiency (33.7 and $25.4 \%$ at 30 and $10 \mathrm{~kg} / \mathrm{d}$, respectively). 
CHAPTER 5

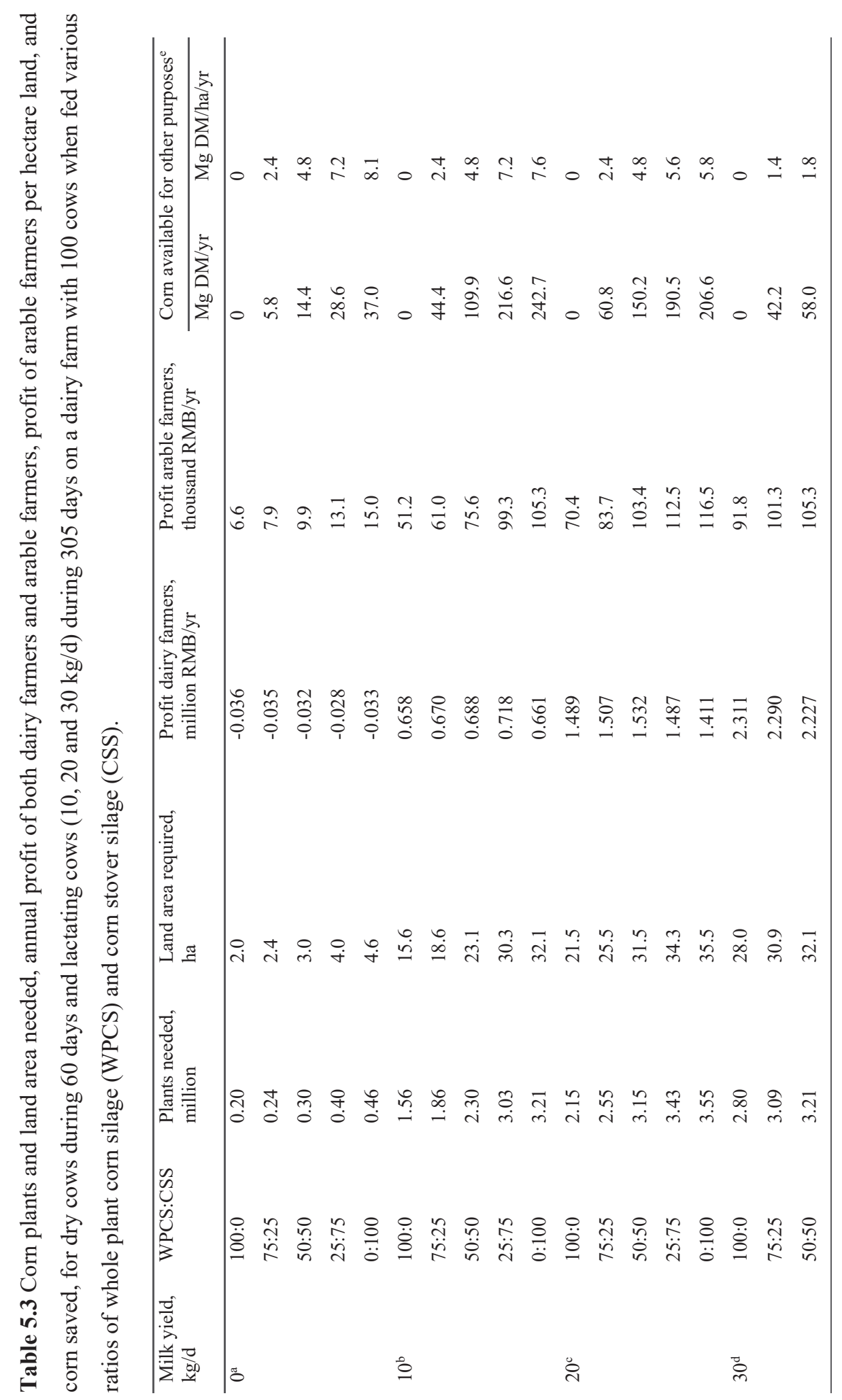


CHAPTER 5

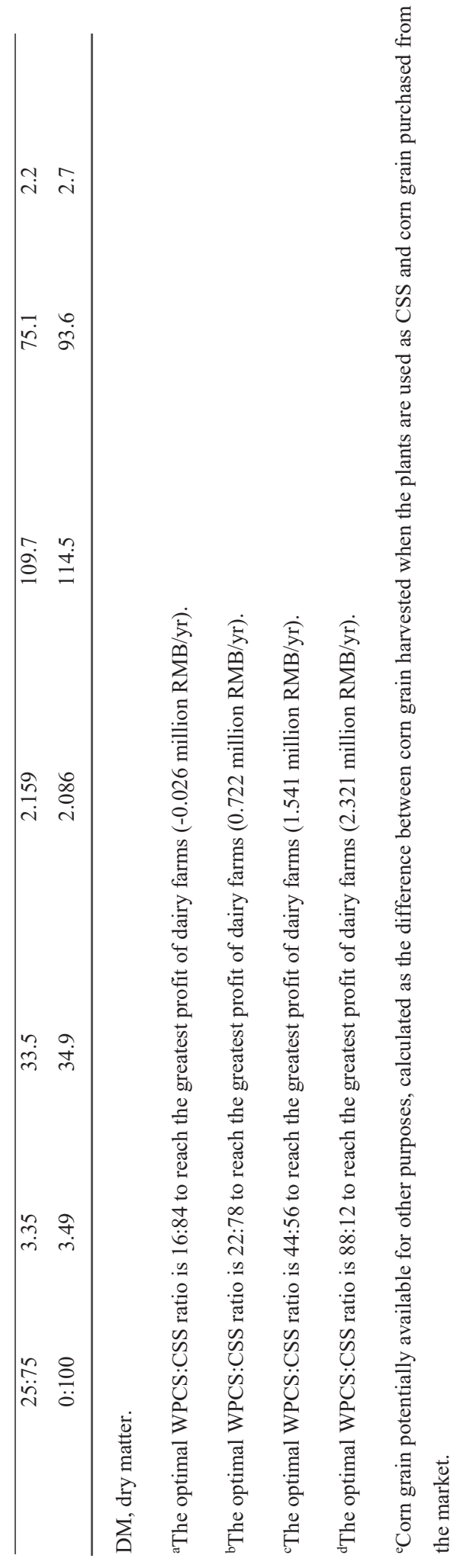


CHAPTER 5

Table 5.4 Number of cows needed to achieve a milk production of $915 \mathrm{Mg} / \mathrm{yr}$, land area needed to grow corn and soybean, and total corn available for other purposes of cows producing 10, 20 and $30 \mathrm{~kg}$ milk daily.

\begin{tabular}{|c|c|c|c|}
\hline \multirow[t]{2}{*}{ Items } & \multicolumn{3}{|c|}{ Milk production, $\mathrm{kg} / \mathrm{d} / \mathrm{cow}$} \\
\hline & 10 & 20 & 30 \\
\hline Cows needed to achieve $915 \mathrm{Mg}$ milk production per year ${ }^{\mathrm{a}}$ & 300 & 150 & 100 \\
\hline WPCS:CSS to reach the highest profit of dairy farms ${ }^{b}$ & $22: 78$ & $44: 56$ & $88: 12$ \\
\hline Land area needed to grow corn plants for dairy farms, $\mathrm{ha}^{\mathrm{c}}$ & 94.2 & 50.2 & 30.3 \\
\hline Corn available for other purposes, $\mathrm{Mg} / \mathrm{ha} / \mathrm{yr}\left(\mathrm{DM}\right.$ basis) ${ }^{\mathrm{d}}$ & 7.4 & 5.4 & 1.1 \\
\hline $\begin{array}{l}\text { Corn grain saved from the land needed to grow corn for dairy farms, } \\
\mathrm{Mg}(\mathrm{DM} \text { basis })^{\mathrm{e}}\end{array}$ & 699.2 & 268.3 & 34.5 \\
\hline Soybean meal needed for dairy farms, $\mathrm{Mg}(\mathrm{DM} \text { basis })^{\mathrm{f}}$ & 108.3 & 98.1 & 91.3 \\
\hline Land area needed to grow soybeans for dairy farms, ha $^{\mathrm{g}}$ & 55.7 & 50.5 & 47.0 \\
\hline Land area needed to grow corn and soybeans for dairy farms, ha & 149.9 & 100.6 & 77.2 \\
\hline Extra land area to grown corn, $\mathrm{ha}^{\mathrm{h}}$ & 0 & 49.3 & 72.7 \\
\hline Corn harvested on the extra land area, $\mathrm{Mg}$ (DM basis) & 0 & 493.0 & 727.0 \\
\hline Total corn available for other purposes, $\mathrm{Mg}$ (DM basis) & 699.2 & 761.3 & 761.5 \\
\hline
\end{tabular}

CSS, corn stover silage; DM, dry matter; WPCS, whole plant corn silage.

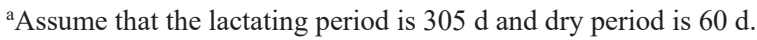

${ }^{b}$ Values were obtained from the model.

${ }^{c}$ Values were calculated based on land areas to grow corn plants for one farm and the farm numbers.

${ }^{\mathrm{d} C}$ Corn grain potentially available for other purposes, calculated as the difference between corn grain harvested when the plants are used as CSS and corn grain purchased from the market.

${ }^{e}$ Values were the product of corn saved per ha and land area to grow corn plants.

${ }^{\mathrm{f}}$ Values were the product of the daily intake of soybean per cow, total number of cows and lactating days.

${ }^{g}$ Soybean yield is $2.76 \mathrm{Mg} / \mathrm{ha}$ (FAO, 2017), $78.7 \%$ of the soybean is soybean meal (Dei, 2011), and DM of soybean meal is $89.5 \%$ (NRC, 2001).

${ }^{\mathrm{h}}$ Compared to the situation of cows producing $10 \mathrm{~kg} / \mathrm{d}$. 


\section{CHAPTER 5}

Table 5.5 Enteric methane production, nitrogen $(\mathrm{N})$ intake and milk $\mathrm{N}$ efficiency of cows producing 10, 20 and $30 \mathrm{~kg}$ milk daily.

\begin{tabular}{llllll}
\hline $\begin{array}{l}\text { Milk yield, } \\
\mathrm{kg} / \mathrm{d}\end{array}$ & WPCS:CSS & $\begin{array}{l}\text { Methane production, } \\
\mathrm{g} / \mathrm{d}\end{array}$ & $\begin{array}{l}\text { Methane intensity, } \\
\mathrm{g} / \mathrm{kg} \text { milk }\end{array}$ & $\begin{array}{l}\mathrm{N} \text { intake, } \\
\mathrm{g} / \mathrm{d}\end{array}$ & $\begin{array}{l}\text { N efficiency } \\
\%\end{array}$ \\
\hline 10 & $100: 0$ & 189 & 18.9 & 192 & 26.3 \\
& $75: 25$ & 192 & 19.2 & 193 & 26.1 \\
& $50: 50$ & 196 & 19.6 & 195 & 25.9 \\
& $25: 75$ & 204 & 20.4 & 198 & 25.5 \\
& $0: 100$ & 203 & 20.3 & 194 & 26.0 \\
& $22: 78$ & 205 & 20.5 & 199 & 25.4 \\
& $100: 0$ & 273 & 13.6 & 319 & 31.6 \\
& $75: 25$ & 276 & 13.8 & 321 & 31.5 \\
& $50: 50$ & 282 & 14.1 & 323 & 31.3 \\
& $25: 75$ & 282 & 14.1 & 320 & 31.6 \\
& $0: 100$ & 281 & 14.0 & 315 & 32.1 \\
& $44: 56$ & 284 & 14.2 & 324 & 31.2 \\
& $100: 0$ & 364 & 12.1 & 449 & 33.7 \\
& $75: 25$ & 365 & 12.2 & 448 & 33.8 \\
& $50: 50$ & 365 & 12.2 & 444 & 34.1 \\
& $25: 75$ & 364 & 12.1 & 439 & 34.5 \\
& $0: 100$ & 364 & 12.1 & 435 & 34.8 \\
& $88: 12$ & 365 & 12.2 & 449 & 33.7 \\
\hline
\end{tabular}

CSS, corn stover silage; WPCS, whole plant corn silage.

${ }^{a}$ Calculated as milk $\mathrm{N}$ yield $(\mathrm{g} / \mathrm{d})$ divided by $\mathrm{N}$ intake $(\mathrm{g} / \mathrm{d}) \times 100$.

The effect of the quality and price of CSS and the price of GC on the land area required to grow corn plants, the profit of dairy farmers and arable farmers and corn saved are shown in Table 5-S1. Two corn cultivars, Perley and Rivaldinio, were selected to do the sensitivity analysis. The CSS of Perley and Rivaldinio had the greatest and lowest predicted ME by the NRC (2001), respectively. The quality of CSS influenced the land area required to grow corn plants and the profit of the dairy farmers. Compared with the cultivar Perley, when Rivaldinio was the corn cultivar selected, more land area was needed to grow the plants, except when all the plants were used as WPCS for dry cows 


\section{CHAPTER 5}

and as CSS in the farms with cows producing $30 \mathrm{~kg}$ milk daily. Rivaldinio, in contrast to Perley, increased the profit of dairy farms with cows producing 20 and $30 \mathrm{~kg} / \mathrm{d}$ milk when WPCS:CSS was 100:0. The corn cultivars (Rivaldinio and Perley) selected did not affect the profit of dairy farms with dry cows when WPCS:CSS was 75:25. In other cases, Perley was a better corn cultivar than Rivaldinio in terms of dairy farm profit. The CSS quality affected the corn available for other purposes when all the plants were harvested as CSS to feed dry cows and cows with $10 \mathrm{~kg}$ milk production daily, more than $75 \%$ of the plants as CSS to feed cows with $20 \mathrm{~kg}$ milk production daily and more than $25 \%$ of the plants as CSS to feed cows with $30 \mathrm{~kg}$ milk production daily. Perley saved more corn for other purposes than Rivaldinio in all the cases described above. No effect of the quality of CSS on the price of WPCS was observed. In contrast, the price of CSS and GC had no influence on the land area needed and corn available for other purposes. The lower price of CSS and GC led to a lower price of WPCS, a lower profit of the arable farmers and a greater profit of the dairy farmers. A greater price of CSS and GC resulted in a greater price of WPCS, a greater profit of the arable farmers and a lower profit of the dairy farmers.

\subsection{Discussion}

The main objective of this study was to evaluate the impact of a change of the WPCS:CSS ratio on the profit of dairy farmers, thus providing guidance for an effective utilization of corn plants. Since the arable farmers also aim to obtain maximum profit, it was necessary to keep the profit of the arable farmers constant with varying WPCS:CSS ratios. In the default situation, the profit of arable farmers was $3281 \mathrm{RMB} / \mathrm{ha} / \mathrm{yr}$. The price of corn stover is always low due to its high lignin content and low degradability (Shi et al., 2015). In our model, the price of fresh corn stover sold by arable farmers was $50 \mathrm{RMB} / \mathrm{Mg}$. According to Shi (2017), the price of WPCS can be set based on the weight of one corn plant, corn grain and corn stover and the price of corn grain and corn stover to make the profit of arable farmers be constant, regardless of the WPCS:CSS ratio. As such, the profit of the arable farmer is influenced by the price of corn stover and ground corn, but not by the quality of the CSS. 


\section{CHAPTER 5}

\subsubsection{Effect of the WPCS:CSS ratio on diet composition and profit of dairy farms}

Ground corn, SBM, WPCS and CSS are commonly used as major feedstuffs in the ration of dry and lactating cows in Chinese dairy farms (Su et al., 2013; Zhu et al., 2013; Wang et al., 2014; Zhang et al., 2015). In our model, a simple ration consisting of GC, SBM, WPCS and/or CSS (Bailey and Ishler, 2007) was formulated to meet the requirements for $\mathrm{NE}$ and MP of cows at different milk production levels.

With no GC included in the ration, the DMI increased with more CSS included to meet the NE requirement of cows, due to the lower energy content of CSS compared with WPCS. This is consistent with Mertens (1994) and Hayirli et al. (2002) who suggested that DMI is positively correlated with NDF concentration when energy limits the intake. Besides, DMI is negatively correlated with NDF concentration when fill of the reticulorumen limits intake (Mertens, 1994; Allen, 2000). Hence, in our model, the maximum amount of NDF included in the ration decreased with increasing milk production level and thus increasing DMI level. When the NDF content in the ration reached this maximum, GC was selected over more CSS in the ration. The greater energy density of GC compared to CSS, contributes to the lower DMI when more GC is added.

Endogenous N losses increase with elevated DMI levels (NRC, 2001), which results in a greater amount of MP required when feed intake increases. The lower MP content in CSS compared with WPCS also resulted in an increasing demand of MP from GC and SBM. Hence, the fraction of SBM in the ration increased with lower WPCS:CSS ratios. However, the greater MP content in GC, compared with CSS, can alleviate the usage of SBM. Because the price of CSS was lower than WPCS and the price of corn grain sold by the arable farmers was lower than GC bought by the dairy farmers in the market (as is the case in China), the profit of dairy farmers increased with lower WPCS:CSS ratios, until GC was included in the ration.

\subsubsection{Effect of the CSS quality on diet composition and profit of dairy farms}

The NDF degradability is of vital importance for dairy cows in terms of milk production and DMI (Oba and Allen, 1999a; Kendall et al., 2009; Holt et al., 2013). Oba and Allen (1999b) proposed that a 1-unit increase in forage NDF degradability in vitro or in situ is associated with an increase of $0.17 \mathrm{~kg} \mathrm{DMI} / \mathrm{d}$ and $0.25 \mathrm{~kg} 4.0 \%$ fat-corrected milk/d. In 


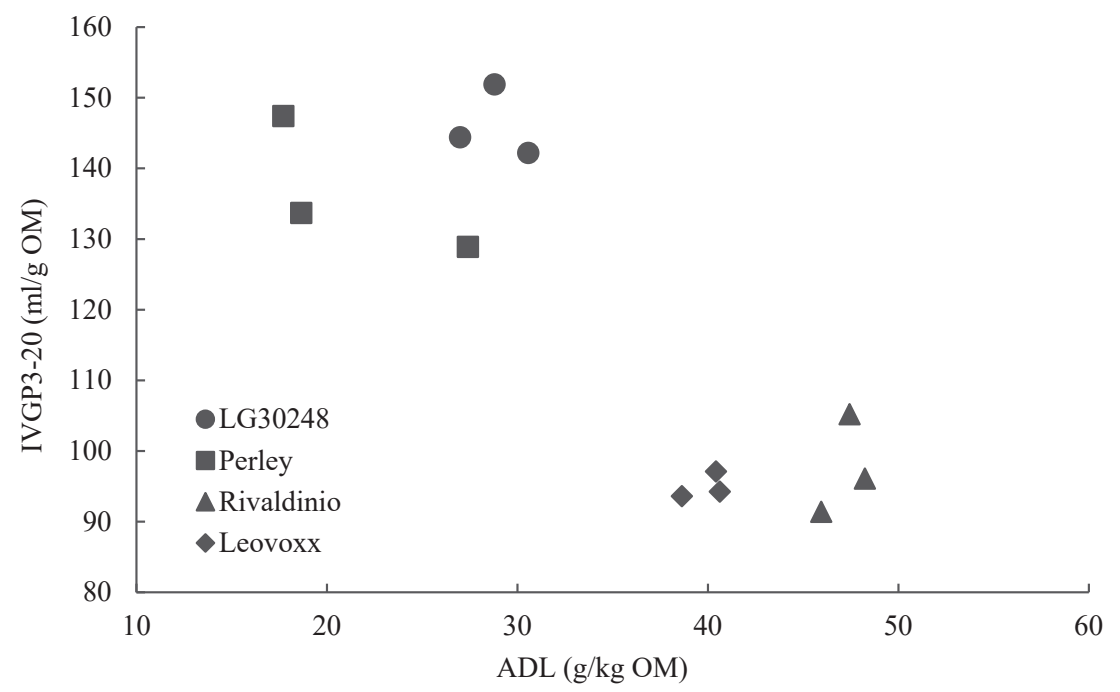

Figure 5.1 Relationship between acid detergent lignin (ADL) content (g/kg organic matter, OM) and in vitro gas production (IVGP) between 3 and $20 \mathrm{~h}$ of incubation in buffered rumen fluid (IVGP3-20; $\mathrm{ml} / \mathrm{g} \mathrm{OM}$ )) of corn stover silage from four cultivars (Lg30248, Perley, Rivaldinio and Leovoxx): IVGP3-20 = -1.94 $\pm 0.386 \times$ ADL $+185 \pm$ 13.7 (estimate \pm standard error), root-mean-square-error 13.68 , adjusted $\mathrm{R}^{2}=0.69$.

previous studies, the lignin content in forages was shown to be negatively correlated to cell wall degradability (Tuyen et al., 2012; Van Kuijk et al., 2015; He et al., 2018). One commonly used method to evaluate the cell wall degradability is the IVGP technique. The IVGP between 3 and 20 hours (IVGP3-20) is assumed to represent the cell wall degradability of forages (Van Gelder et al., 2005). The relationship between ADL content expressed on an organic matter (OM) basis and IVGP3-20 of CSS is shown in Figure 5.1. The ADL content of CSS has a good correlation (adjusted $\mathrm{R}^{2}=0.69$ ) with the cell wall degradability of CSS. A greater NDF degradability will result in a greater ME content, and CSS of Perley (lowest ADL content) indeed had the greatest ME content, while Rivaldinio (highest ADL content) had the lowest ME content. Considering both the predicted ME value from 


\section{CHAPTER 5}

NRC (2001) and the NDF degradability evaluated using the IVGP of CSS from the 4 cultivars, Perley and Rivaldinio were selected for the sensitivity analysis.

Since the aim of our model was to formulate rations for cows with a pre-defined milk production, the beneficial effects of a greater NDF degradability on milk production was not observed. However, due to the greater ME value of CSS from Perley relative to Rivaldinio, less feed is required to meet the energy demand of the cows (Table 5.6), indicating that feed efficiency of cows fed with Perley corn plants was higher than that of cows fed with Rivaldinio, and more corn grain can be saved for other purposes (Table 5$\mathrm{S} 1)$. When the NDF content in the ration did not reach the limit, which was set in our model based on the production levels, the inclusion rate of Perley in the ration was lower than that of Rivaldinio. When the NDF content in the diet limited the inclusion of CSS, more Perley could be incorporated due to its lower NDF content. However, Perley contained less CP than the other three corn cultivars, which resulted in the inclusion of more SBM. Therefore, the use of Perley did not benefit the profit margin of dairy farmers in some cases. Collectively, the results indicate that corn plants with a greater NDF degradability may not only be beneficial for cows in early lactation, during which energy intake cannot meet the requirements due to the low DMI (Holt et al., 2013), but also contribute to more corn available for other purposes.

\subsubsection{Effect of milk production levels on land use, methane emission and milk $\mathrm{N}$ efficiency}

Due to the low NE requirement, the lower producing dairy cows require less corn grain than the high producing cows, and at a fixed number of cows, more corn grain is available for other purposes from the land needed to grow corn for dairy farms with low producing cows (Table 5.4). However, the amount of corn saved for other purposes should be placed into the perspective of the amount of milk produced. Therefore, a fixed level of $915 \mathrm{Mg} / \mathrm{yr}$ milk production, which was the milk production from one dairy farm with 100 dairy cows producing $30 \mathrm{~kg} / \mathrm{d}$ milk and having 305 lactating days and $60 \mathrm{~d}$ dry period, was set as a goal to be achieved by dairy farms with cows producing 10 and $20 \mathrm{~kg} / \mathrm{d}$ milk. At this fixed total milk production level, more land area is required upon a reduction in milk production level per cow, and more land is available to grow corn at high milk production level per cow. Therefore, our simulations indicate that in total a greater amount of corn 
will be available for other purposes when dairy cows produce 20 and $30 \mathrm{~kg}$ milk/d, compared with cows producing $10 \mathrm{~kg}$ milk/d. All cows, regardless of milk production levels, are assumed to have the same NE requirement for maintenance. Therefore, upon an increase in milk production level, a smaller proportion of feed energy intake is partitioned toward meeting maintenance needs and a greater proportion is transferred to milk (VandeHaar and St-Pierre, 2006). The 300 cows with $10 \mathrm{~kg} / \mathrm{d}$ milk production need more NE to produce $915 \mathrm{Mg} / \mathrm{yr}$ milk than the 150 cows with $20 \mathrm{~kg} / \mathrm{d}$ milk production and the 100 cows with $30 \mathrm{~kg} / \mathrm{d}$ milk production, resulting in less corn saved for other purposes. A discount factor is applied to predict the digestible energy of feedstuffs at different production levels, and the factor is larger when cows have a greater milk production (NRC, 2001). Although the cows producing $30 \mathrm{~kg}$ milk/d are more efficient than the cows

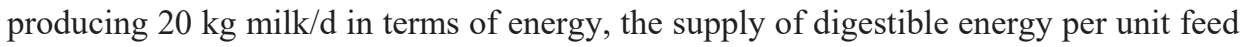
is lower, resulting in only a small increase in corn available for other purposes when milk production increases from 20 to $30 \mathrm{~kg} / \mathrm{d}$.

Methane emission from ruminants receives global interest (Hristov et al., 2013). Van Gastelen et al. (2015) found that replacing grass silage with WPCS for dairy cattle is an effective strategy to decrease enteric methane production without negatively affecting dairy cow performance. In the present study, within a certain milk production level, the increased methane production is mainly caused by replacing starch-rich WPCS with fiber-rich CSS. Fermentation of fiber favors the ruminal production of acetic acid, which increases hydrogen availability and activity of rumen methanogens (Hook et al., 2011; Van Kessel and Russell, 1996). We assumed a fixed yield of $\mathrm{CH}_{4}$ per $\mathrm{kg}$ DM of WPCS; increasing harvest maturity of WPCS may reduce $\mathrm{CH}_{4}$ yield (Hatew et al., 2016) and may offer opportunities to further reduce $\mathrm{CH}_{4}$ emissions from dairy cattle. Not only the dietary composition (particularly the type of carbohydrates), but also the level of feed intake influences the enteric methane production (Beauchemin et al., 2008; Ellis et al., 2008). It is without doubt that the high producing cows emit greater amounts of methane since they have a higher level of DMI. However, the amount of methane produced should be placed in the context of the amount of milk produced. It can be seen from our simulations that high producing cows have lower methane intensity. Nitrogen emission to the environment, which is related with the $\mathrm{N}$ efficiency, is another environmental concern in dairy production. The results in the present study demonstrated that greater milk production has the potential to improve milk $\mathrm{N}$ efficiency, which is similar to the finding of Dijkstra et 


\section{CHAPTER 5}

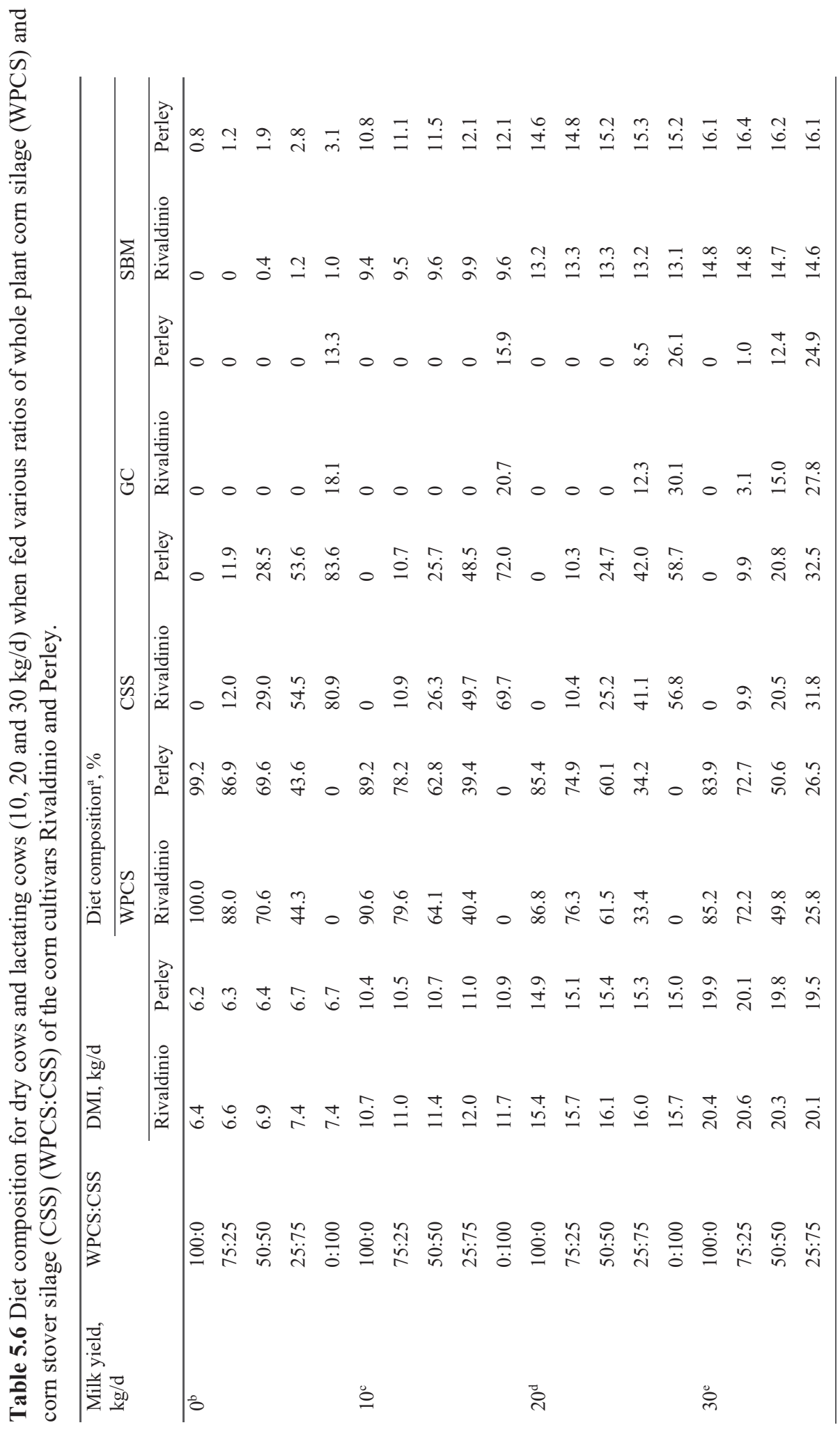


CHAPTER 5

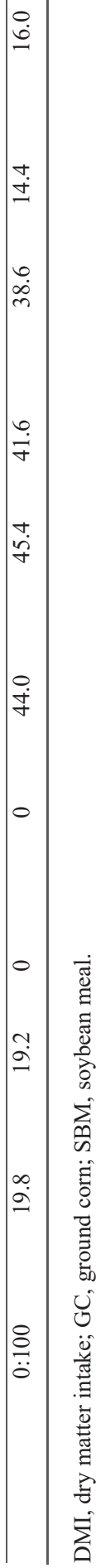




\section{CHAPTER 5}

al. (2013) that the maximum milk $\mathrm{N}$ efficiency increases upon an increase in milk production from 3000 to $9000 \mathrm{~kg}$ per year. Nadeau et al. (2007) reported that milk N efficiency decreased with decreasing milk yield, with $32.8 \%$ for cows producing more than $35 \mathrm{~kg} \mathrm{milk/d}, 30.6 \%$ for cows producing $25-35 \mathrm{~kg}$ milk/d and $26.8 \%$ for cows producing less than $25 \mathrm{~kg}$ milk/d. The milk $\mathrm{N}$ efficiency of cows producing 20 and $30 \mathrm{~kg}$ milk/d that was reported by Nadeau et al. (2007) was lower than the results in our study, mainly because the cows in the present model were assumed to be non-pregnant and there was no MP partitioned to the demand of pregnancy. The increased milk $\mathrm{N}$ efficiency of cows producing greater amounts of milk may be the result of a greater proportion of MP being partitioned to milk with greater amount of MP intake since the cows in different production levels are assumed to have the same MP requirement for maintenance.

\subsection{Conclusion}

The optimal WPCS:CSS ratio to reach the greatest profit of dairy farmers changed with the production level of the cows, with a lower WPCS:CSS ratio for cows with a lower milk production. At a fixed total amount of milk being produced, more land will be available to grow corn and more corn will be available for other purposes including human consumption, with high producing cows. At the optimal WPCS:CSS ratio for each milk production level, methane emission intensity is smaller, and milk $\mathrm{N}$ efficiency is greater, with high producing cows compared with low producing cows, which may alleviate the environment pollution related to dairy production.

\subsection{Acknowledgments}

We thank the Sino-Dutch Dairy Development Centre for their financial support. Limagrain (Limagrain Nederland BV, Rilland, the Netherlands) is acknowledged for providing the corn plants Lg30248 and Perley. Gerard Derks (Wageningen University \& Research, Wageningen, the Netherlands) is acknowledged for helping collect corn plants Rivaldinio and Leovoxx from the experimental field of Unifarm (Wageningen, the Netherlands). 


\section{CHAPTER 5}

\subsection{References}

Akins, M., Ferraretto, L., Fredin, S., Hoffman, P., Shaver, R., 2012. Balancing carbohydrate sources for dairy cows during a period of high corn prices. Proceeding in Four-State Dairy Nutrition and Management Conference, Dubuque, Iowa. pp. 18-23.

Allen, M.S., 2000. Effects of diet on short-term regulation of feed intake by lactating dairy cattle. J. Dairy Sci. 83, 1598-1624.

Amours, L.D., Savoie, P., 2005. Density profile of corn silage in bunker silos. Can. Biosyst Eng. 47, 21-28.

Bailey, K., Ishler, V., 2007. Tracking milk prices and feed costs. Department of Agricultural Economics and Rural Sociology, Penn. State University. https://extension.psu.edu/dairy-risk-management-education-tracking-milk-prices-andfeed-costs.

Bannink, A., France, J., Lopez, S., Gerrits, W.J.J., Kebreab, E., Tamminga, S., Dijkstra, J., 2008. Modelling the implications of feeding strategy on rumen fermentation and functioning of the rumen wall. Anim. Feed Sci. Technol. 143, 3-26.

Beauchemin, K.A., Kreuzer, M., O’Mara, F., McAllister, T.A., 2008. Nutritional management for enteric methane abatement: A review. Aust. J. Exp. Agric. 48, 21-27.

Buza, M.H., Holden, L.A., White, R.A., Ishler, V.A., 2014. Evaluating the effect of ration composition on income over feed cost and milk yield. J. Dairy Sci. 97, 3073-3080.

Cantalapiedra-Hijar, G., Peyraud, J.L., Lemosquet, S., Molina-Alcaide, E., Boudra, H., Nozière, P., Ortigues-Marty, I., 2014. Dietary carbohydrate composition modifies the milk $\mathrm{N}$ efficiency in late lactation cows fed low crude protein diets. Anim. 8, 275-285.

Cone, J.W., Rodrigues, M.A.M., Guedes, C.M., Blok, M.C., 2009. Comparison of protein fermentation characteristics in rumen fluid determined with the gas production technique and the nylon bag technique. Anim. Feed Sci. Technol. 153, 28-38.

Cone, J.W., Van Gelder, A.H., Driehuis, F., 1997. Description of gas production profiles with a three-phasic model. Anim. Feed Sci. Technol. 66, 31-45.

Dairy Association of China, The report of dairy quality in China, 2017. www.dac.org.cn/upload-/fckupload/file/1500348352177849679367.pdf. (In Chinese). 


\section{CHAPTER 5}

Dei, H.K., 2011. Soybean as a feed ingredient for livestock and poultry. In: Krezhova, D. (Ed.), Recent Trends for Enhancing the Diversity and Quality of Soybean Products. InTech Open Access Publisher, Rijeka, pp. 215-226.

Der Bedrosian, M.C., Nestor Jr., K.E., Kung Jr., L., 2012. The effects of hybrid, maturity, and length of storage on the composition and nutritive value of corn silage. J. Dairy Sci. $95,5115-5126$.

Dijkstra, J., Reynolds, C.K., Kebreab, E., Bannink, A., Ellis, J.L., France, J., Van Vuuren, A.M., 2013. Challenges in ruminant nutrition: Towards minimal nitrogen losses in cattle. In: Oltjen, W.J., Kebreab, E., Lapierre, H. (Eds.), Energy and Protein Metabolism and Nutrition in Sustainable Animal Production. Wageningen Academic Publishers, Wageningen, pp. 47-58.

Ellis, J.L., Dijkstra, J., Kebreab, E., Bannink, A., Odongo, N.E., McBride, B.W., France, J., 2008. Aspects of rumen microbiology central to mechanistic modelling of methane production in cattle. J. Agric. Sci. 146, 213-233.

Fan, S., Shi, J., 2014. A study on the cost and benefit to grow corn plants in China. Dissertation. Shandong Agricultural University. (In Chinese).

FAO (Food and Agriculture Organization of the United Unions). FAOSTAT. Rome, Italy, 2017.

Givens, D.I., Rymer, C., Cottrill, B.R., Offer, N.W., Thomas, C., 2004. Protein requirement and supply. In: Thomas, C. (Ed.), Feed into Milk: A New Applied Feeding System for Dairy Cows. Nottingham University Press, Nottingham, pp. 21-40.

Godfray, H.C.J., Beddington, J.R., Crute, I.R., Haddad, L., Lawrence, D., Muir, J.F., Pretty, J., Robinson, S., Thomas, S.M., Toulmin, C., 2010. Food security: the challenge of feeding 9 billion people. Science. 327, 812-818.

Hatew, B., Bannink, A., Van Laar, H., De Jonge, L.H., Dijkstra, J., 2016. Increasing harvest maturity of whole-plant corn silage reduces methane emission of lactating dairy cows. J. Dairy Sci. 99, 354-368.

Hayirli, A., Grummer, R.R., Nordheim, E.V., Crump, P.M., 2002. Animal and dietary factors affecting feed intake during the prefresh transition period in Holsteins. J. Dairy Sci. 85, 3430-3443. 
He, Y., Cone, J.W., Hendriks, W.H., Dijkstra, J. Relationships between chemical composition and in vitro gas production parameters of corn leaves and stems. J. Anim. Physiol. Anim. Nutr. Submitted.

He, Y., Mouthier, T.M.B., Kabel, M.A., Dijkstra, J., Hendriks, W.H., Struik, P.C., Cone, J.W., 2018. Lignin composition is more important than content for maize stem cell wall degradation. J. Sci. Food Agric. 98, 384-390.

Holt, M.S., Eun, J.S., Thacker, C.R., Young, A.J., Dai, X., Nestor Jr., K.E., 2013. Effects of feeding brown midrib corn silage with a high dietary concentration of alfalfa hay on lactational performance of Holstein dairy cows for the first 180 days of lactation. J. Dairy Sci. $96,515-523$.

Hook, S.E., Steele, M.A., Northwood, K.S., Wright, A.G., McBride, B.W., 2011. Impact of high-concentrate feeding and low ruminal $\mathrm{pH}$ on methanogens and protozoa in the rumen of dairy cows. Microbiol. Ecol. 62, 94-105.

Hristov, A.N., Oh, J., Firkins, J.L., Dijkstra, J., Kebreab, E., Waghorn, G., Makkar, H.P.S., Adesogan, A.T., Yang, W., Lee, C., Gerber, P.J., Henderson, B., Tricarico, J.M., 2013. Special topics-Mitigation of methane and nitrous oxide emissions from animal operations: I. A review of enteric methane mitigation options. J. Anim. Sci. 91, 5045-5069.

Huisden, C.M., Adesogan, A.T., Kim, S.C., Ososanya, T., 2009. Effect of applying molasses or inoculants containing homofermentative or heterofermentative bacteria at two rates on the fermentation and aerobic stability of corn silage. J. Dairy Sci. 92, 690697.

Johnson, L.M., Harrison, J.H., Davidson, D., Robutti, J.L., Swift, M., Mahanna, W.C., Shinners, K., 2002. Corn silage management I: effects of hybrid, maturity, and mechanical processing on chemical and physical characteristics. J. Dairy Sci. 85, 833853.

Kendall, C., Leonardi, C., Hoffman, P.C., Combs, D.K., 2009. Intake and milk production of cows fed diets that differed in dietary neutral detergent fiber and neutral detergent fiber digestibility. J. Dairy Sci. 92, 313-323.

Khan, N.A., Yu, P., Ali, M., Cone, J.W., Hendriks, W.H., 2015. Nutritive value of maize silage in relation to dairy cow performance and milk quality. J. Sci. Food Agric. 95, 238252. 


\section{CHAPTER 5}

Kohler, B., Diepolder, M., Ostertag, J., Thurner, S., Spiekers, H., 2013. Dry matter losses of grass, lucerne and maize silages in bunker silos. Agric. Food Sci. 22, 145-150.

Kristensen, N.B., Sloth, K.H., Højberg, O., Spliid, N.H., Jensen, C., Thøgersen, R., 2010. Effects of microbial inoculants on corn silage fermentation, microbial contents, aerobic stability, and milk production under field conditions. J. Dairy Sci. 93, 3764-3774.

Li, S., Yao, K., Cao, Z., Liu, C., Zhang, S., Liu, J., Li, J., Wang, J., Zhang, H., 2018. Dairy industry and technical development report in 2017. Chinese J. Anim. Sci. 3, 132137. (In Chinese).

Liu, C.G., 2016. China Dairy Yearbook. China Agriculture Press, Beijing. (In Chinese). Menke, K.H., Raab, L., Salewski, A., Steingass, H., Fritz, D., Schneider, W., 1979. The estimation of the digestibility and metabolizable energy content of ruminant feedingstuffs from the gas production when they are incubated with rumen liquor in vitro. J. Agric. Sci. 93, 217-22.

Mertens, D.R., 1994. Regulation of forage intake. In: Fahey, G.C., Collins Jr., M., Mertens, D.R., Moser, L.E. (Eds.), Forage Quality, Evaluation, and Utilization. American Society of Agronomy, Crop Science Society of America, and Soil Science Society of America, Madison, pp. 450-493.

Nadeau, E., Englund, J.E., Gustafsson, A.H., 2007. Nitrogen efficiency of dairy cows as affected by diet and milk yield. Livest. Sci. 111, 45-56.

National Development and Reform Commission, Collection on the cost and profit of China agricultural products. China Statistics Press, Beijing, 2017.

NRC. Nutrient Requirements of Dairy Cattle. 7th revised ed. Washington: National Academy Press; 2001.

Oba, M., Allen, M.S., 1999a. Effects of brown midrib 3 mutation in corn silage on dry matter intake and productivity of high yielding dairy cows. J. Dairy Sci. 82, 135-142.

Oba, M., Allen, M.S., 1999b. Evaluation of the importance of digestibility of neutral detergent fiber from forage: Effects on dry matter intake and milk yield of dairy cows. J. Dairy Sci. 82, 589-596.

Scheiner, D., 1976. Determination of ammonia and Kjeldahl nitrogen by indophenol 
method. Water Res. 10, 31-36.

Shi, H.T., Li, S.L., Cao, Z.J., Wang, Y.J., Alugongo, G.M., Doane, P.H., 2015. Effects of replacing wild rye, corn silage, or corn grain with $\mathrm{CaO}$-treated corn stover and dried distillers grains with solubles in lactating cow diets on performance, digestibility, and profitability. J. Dairy Sci. 98, 7183-7193.

Shi, S., 2017. How to pricing corn silage in China. China Dairy Cattle, 8, 7-13.

Shinners, K.J., Binversie, B.N., Muck, R.E., Weimer, P.J., 2007. Comparison of wet and dry corn stover harvest and storage. Biomass Bioenergy 31, 211-221.

Su, H., Wang, Y., Zhang, Q., Wang, F., Cao, Z., Rahman, M.A.U., Cao, B., Li, S., 2013. Responses of energy balance, physiology, and production for transition dairy cows fed with a low-energy prepartum diet during hot season. Trop. Anim. Health Prod. 45, 1495 1503.

Tolera, A., Berg, T., Sundstol, F., 1999. The effect of variety on maize grain and crop residue yield and nutritive value of the stover. Anim. Feed Sci. Technol. 79, 165-177.

Tuyen, V.D., Cone, J.W., Baars, J.J.P., Sonnenberg, A.S.M., Hendriks, W.H., 2012. Fungal strain and incubation period affect chemical composition and nutrient availability of wheat straw for rumen fermentation. Bioresour. Technol. 111, 336-342.

VandeHaar, M.J., St-Pierre, N., 2006. Major advances in nutrition: Relevance to the sustainability of the dairy industry. J. Dairy Sci. 89, 1280-1291.

Van Gastelen, S., Antunes-Fernandes, E.C., Hettinga, K.A., Klop, G., Alferink, S.J.J., Hendriks, W.H., Dijkstra, J., 2015. Enteric methane production, rumen volatile fatty acid concentrations, and milk fatty acid composition in lactating Holstein-Friesian cows fed grass silage- or corn silage-based diets. J. Dairy Sci. 98, 1915-1927.

Van Gelder, A.H., Hetta, M., Rodrigues, M.A.M., De Boever, J.L., Den Hartigh, H., Rymer, C., Van Oostrum, M., Van Kaathoven, R., Cone J.W., 2005. Ranking of in vitro fermentability of 20 feedstuffs with an automated gas production technique: Results of a ring test. Anim. Feed Sci. Technol. 123-124, 243-253.

Van Kessel, J.A.S., Russell, J.B., 1996. The effect of $\mathrm{pH}$ on ruminal methanogenesis. FEMS Microbiol. Ecol. 20, 205-210. 


\section{CHAPTER 5}

Van Kuijk, S.J.A., Sonnenberg, A.S.M., Baars, J.J.P., Hendriks, W.H., Cone, J.W., 2015. Fungal treatment of lignocellulosic biomass: importance of fungal species, colonization and time on chemical composition and in vitro rumen degradability. Anim. Feed Sci. Technol. 209, 40-50.

Van Soest, P.J., Robertson, J.B., Lewis, B.A., 1991. Methods for dietary fiber, neutral detergent fiber, and nonstarch polysaccharides in relation to animal nutrition. J. Dairy Sci. 74, 3583-3597.

Van Soest, P.J., McQueen, R.W., 1973. The chemistry and estimation of fibre. Proc. Nutr. Soc. $32,123-130$.

Vellinga, T.V., Blonk, H., Marinussen, M., Van Zeist, W.J., De Boer, I.J.M., Starmans, D., 2013. Methodology used in FeedPrint: A tool quantifying greenhouse gas emissions of feed production and utilization. Wageningen UR, Livestock Research, Lelystad, the Netherlands, $108 \mathrm{p}$.

Verbic, J., Stekar, J.M.A., Resnik-Cepon, M., 1995. Rumen degradation characteristics and fibre composition of various morphological parts of different maize hybrids and possible consequences for breeding. Anim. Feed Sci. Technol. 54, 133-148.

Wang, B., Mao, S.Y., Yang, H.J., Mu, Y.M., Wang, J.K., Li, S.L., Shen, Z.M., Liu, J.X., 2014. Effects of alfalfa and cereal straw as a forage source on nutrient digestibility and lactation performance in lactating dairy cows. J. Dairy Sci. 97, 7706-7015.

Yan, J., Gao, Y., Wang, W., Mu, S., 2009. Variation law of whole-plant corn silage nutritional quality under different storage period. J. Northwest A\&F Univ. 37, 75-80.

Zhang, Q., Su, H., Wang, F., Cao, Z., Li, S., 2015. Effects of energy density in close-up diets and postpartum supplementation of extruded full-fat soybean on lactation performance and metabolic and hormonal status of dairy cows. J. Dairy Sci. 98, 71157130.

Zhu, W., Fu, Y., Wang, B., Wang, C., Ye, J.A., Mu, Y.M., Liu, J.X., 2013. Effects of dietary forage sources on rumen microbial protein synthesis and milk performance in early lactating dairy cows. J. Dairy Sci. 96, 1727-1734. 
CHAPTER 5

Supplementary information for:

Corn stover usage and farm profit for sustainable dairy farming in China

Yuan He, John W. Cone, Wouter H. Hendriks, Jan Dijkstra 


\section{CHAPTER 5}

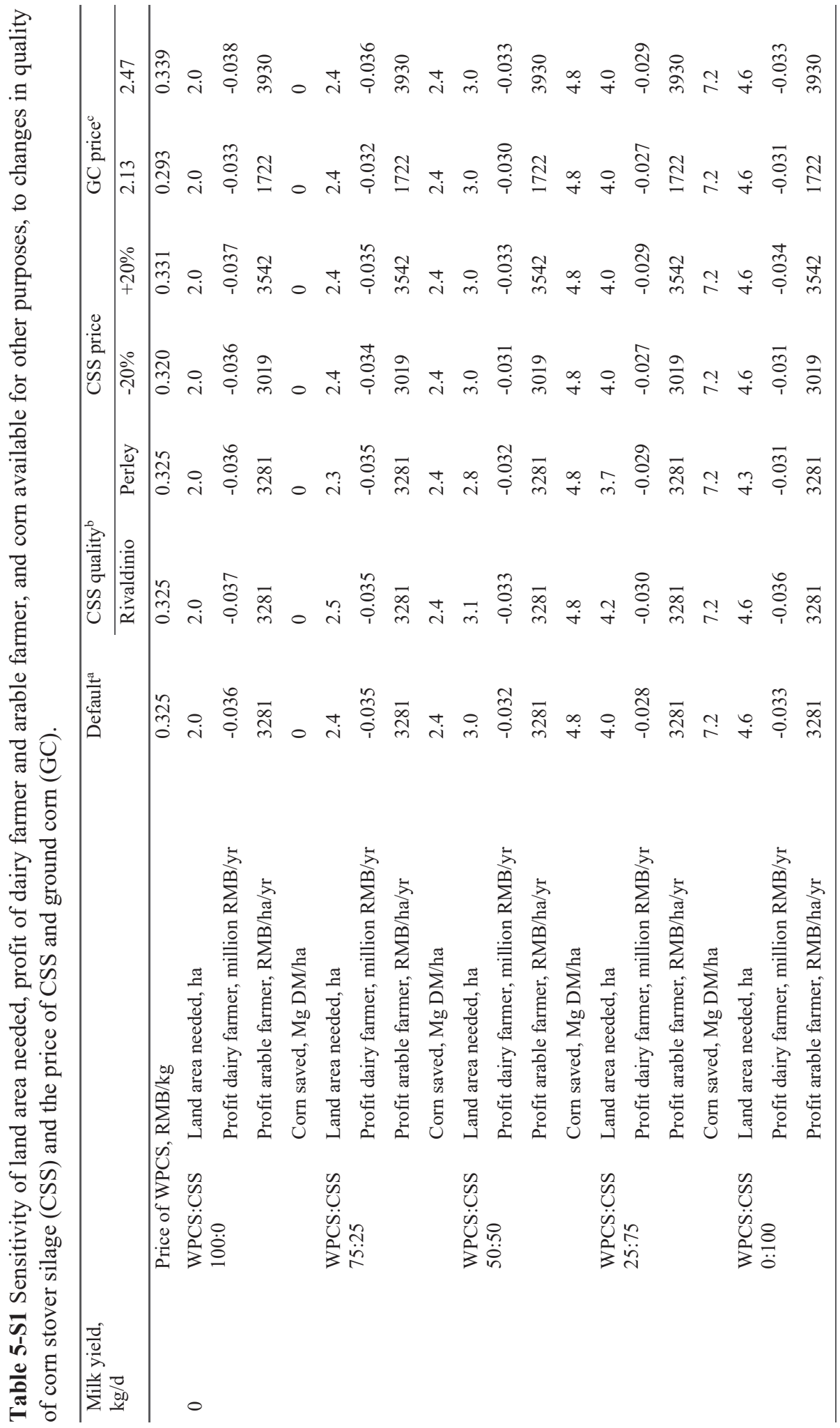


CHAPTER 5

क क क क

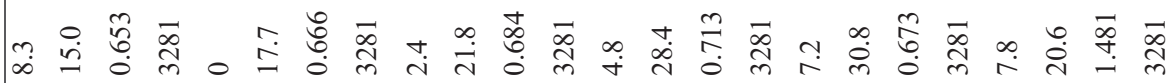

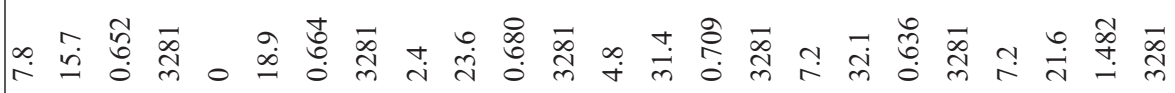

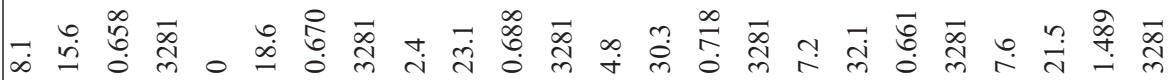

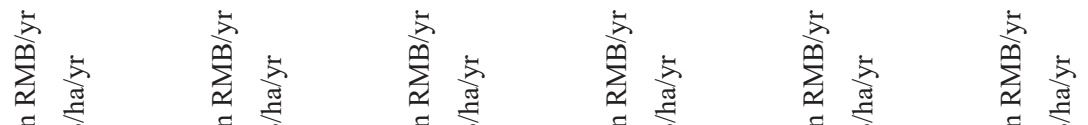

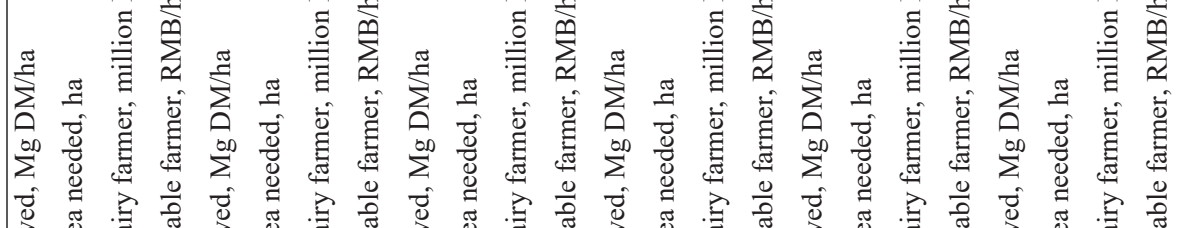

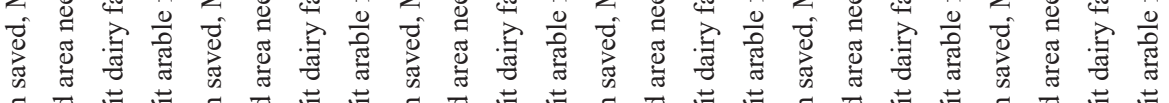

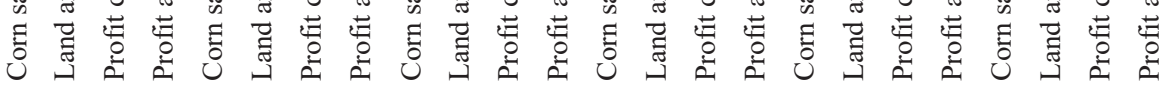

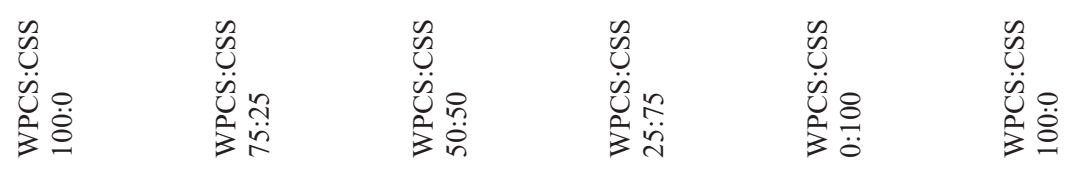




\section{CHAPTER 5}

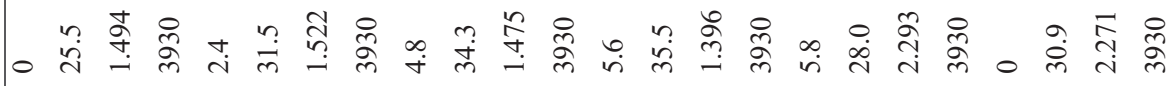

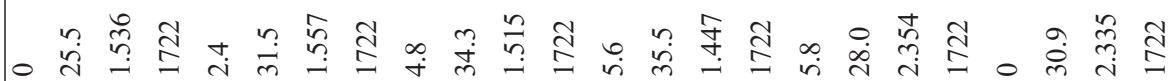

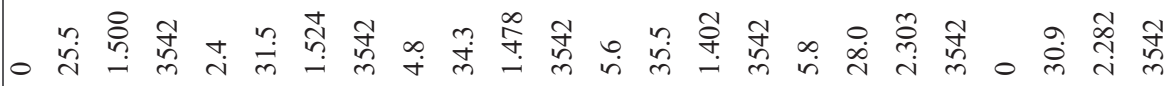

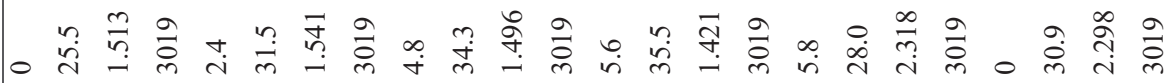

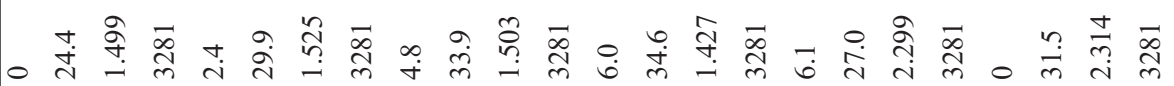

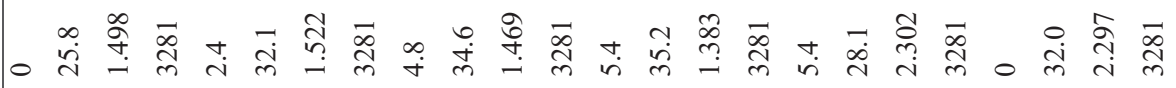

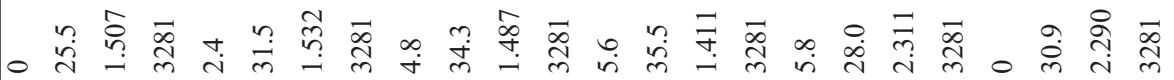

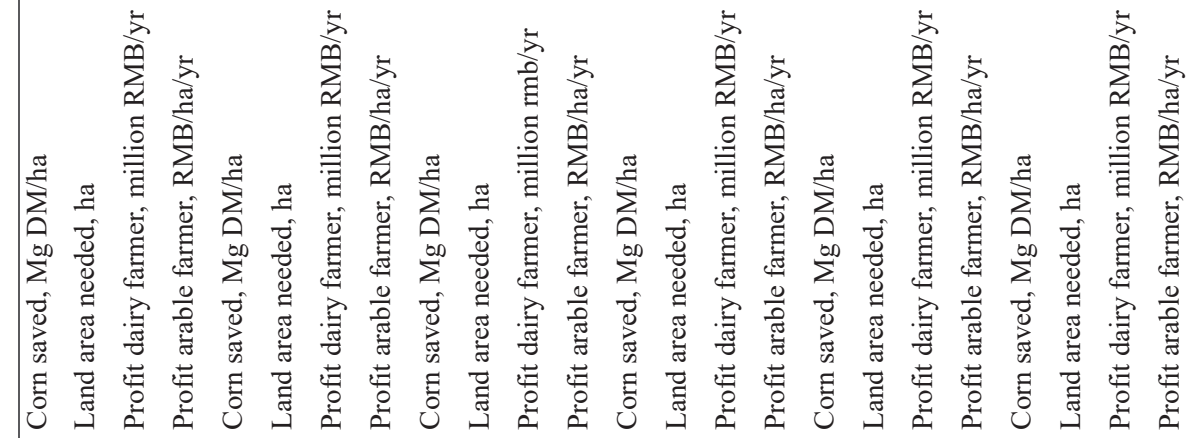

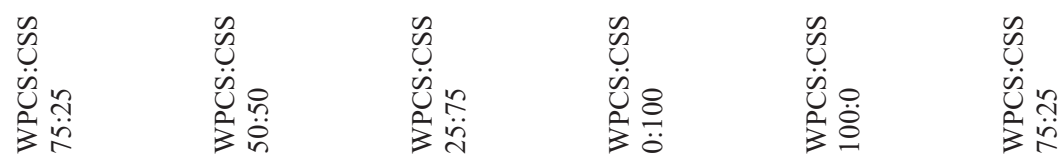


CHAPTER 5

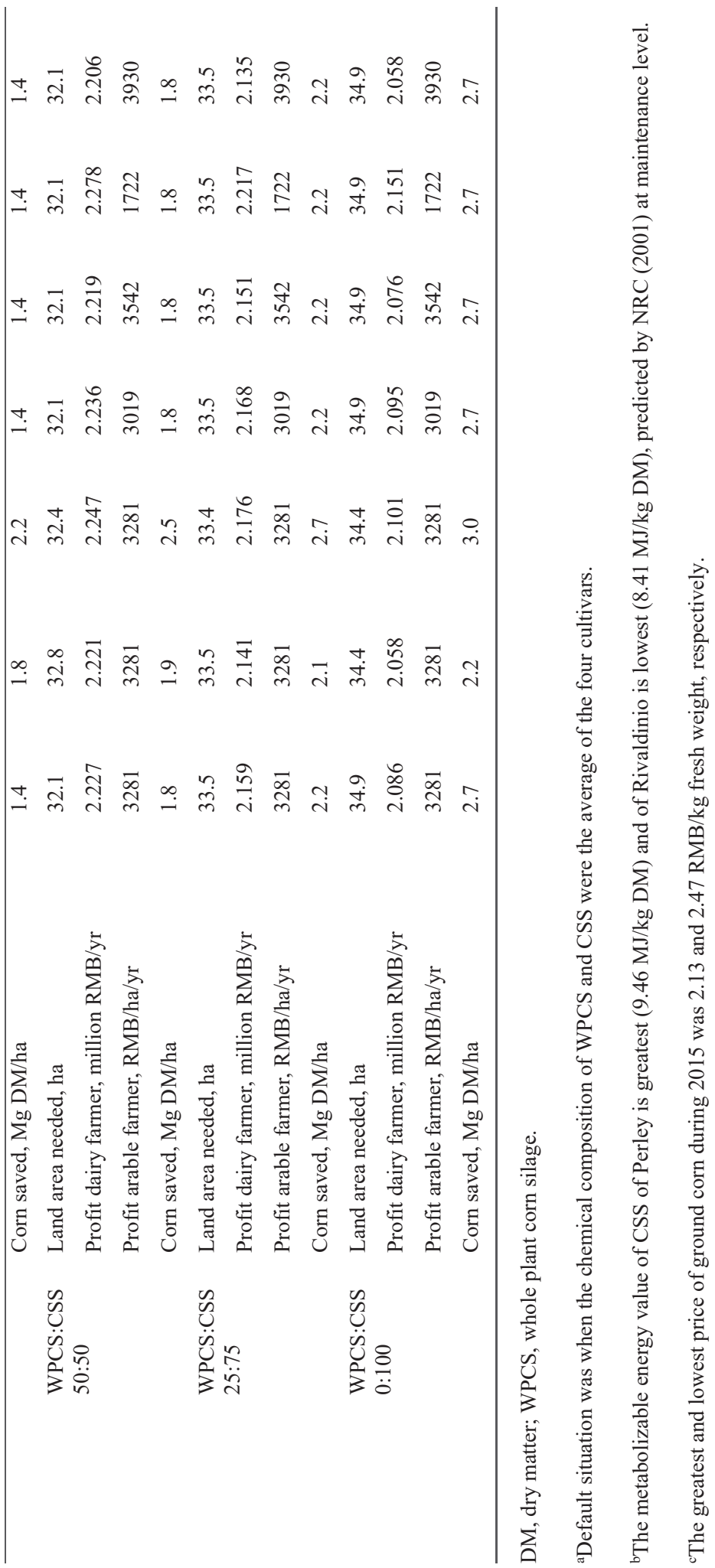


Chapter 6

General discussion 


\section{CHAPTER 6}

The general aim of this thesis was to improve the utilization of corn stover (leaves and stems) in dairy farms in China through evaluating cell wall degradability in vitro and incubating the least degradable part of corn stover with fungi, followed by an economic evaluation to optimize profitability of dairy farms, including consequences of corn stover inclusion in dairy cattle rations for the food - feed competition, methane emission, and milk $\mathrm{N}$ efficiency. Since the price of raw milk has been decreasing and the price of high-quality forages has been increasing in recent years in China (Liu and Li, 2017; Li et al., 2018), the profit for dairy farmers is of concern. Improving the utilization of corn stover in dairy farms may reduce the feed costs and contribute to more profit. However, the low degradability of corn stover hampers its inclusion in the rations of high producing dairy cows. Upon an improvement of the degradability of corn stover, more dairy farms may use corn stover in their rations for dairy cows.

\subsection{The least degradable part of corn stover}

The first objective of the thesis was to explore the least degradable part of corn stover, followed by evaluation of fungal treatment that can increase the rumen degradability of many crop residues. Both Harika and Sharma (1994) and Verbic et al. (1995) reported that the $48 \mathrm{~h}$ dry matter (DM) degradability (measured by the in situ method in sheep or cattle) of leaves was greater than that of stems of corn plants. However, the cell wall degradability, which is critical to evaluate forage quality for dairy cows, of the leaves and stems separately was not investigated yet. In Chapter 2, it was found that for most corn cultivars, the acid detergent lignin (ADL) content was greater and the cell wall degradability, which was evaluated by the in vitro gas production (IVGP) technique, was lower in the stems than in the leaves. The greater ADL content in the stems than in the leaves of corn plants was also demonstrated by Verbic et al. (1995), which may result in the lower cell wall degradability of stems than of leaves reported in Chapter 2, since lignin content in forages is negatively related with rumen cell wall degradability (Boon et al., 2005; Arora and Sharma, 2009; Tuyen et al., 2012). The different ADL content in the leaves and stems may be related with their physiological function. The major function of leaves is photosynthesis, whilst the stem has to be more lignified to provide structural support to the plant. During maturation, both leaves and stems will be more lignified, but the lignification is more pronounced in the stems than in the 
leaves (Morrison, 1980; Ammar et al., 1999). In line with the smaller rate of lignification of the leaves than of the stems during maturation, the decline in degradability of leaves was less pronounced than that of stems (Lentz and Buxton, 1992). Collins (1988) and Gilliland (1997) observed that at the initial stages of development, the stems and leaves had similar degradability, but after stem elongation, stems were less degradable than leaves in both grasses and legumes. However, the ADL content only explained $16 \%$ of the variation of cell wall degradability of corn leaves (Chapter 2). This is in line with Verbic et al. (1995) who reported that the correlation coefficient between the degradability of leaves and the ADL content was -0.13 . In corn stems, the ADL content is more related with cell wall degradability $\left(\mathrm{R}^{2}=0.65\right.$, Chapter 2). It is worth to further explore the factors that determine the degradability of corn leaves.

In Chapter 3, the ADL content of 6 internodes from 2 corn cultivars was analyzed and it can be concluded that the lower internodes were more lignified than the upper ones (Figure 6.1). Within the stem of corn plants, the upper internodes are physiologically younger than the lower ones (Morrison and Buxton, 1993). Due to the negative relationship between ADL content and cell wall degradability of forages, the lower parts of corn stem are less degradable than the upper parts. Internode 5 and 7 contained a greater amount of lignin than the other investigated internodes, so internodes 5, 6 and 7 were designed as lower part of the stem (Chapter 4). Because internode 13 and 15 were thin with a low weight, internode 12 was allocated to the upper part of the stem, together with internode 13,14 and 15, although the ADL content of internode 12 was not measured. The other internodes, namely 8,9,10 and 11, were classified into the middle part of the stem. The lower part of the stem was expected to be the most lignified and the least degradable part among the three parts and the results shown in Chapter 4 showed this to be the case.

As the lower part of corn stems is the least degradable part of corn stover, it was hypothesized that the degradation of the lower stem can be enhanced by fungal treatment. However, the hypothesis was rejected based on the results in Chapter 4. Therefore, in the economic modelling research (Chapter 5) this fungal treatment of the lower part of corn stems and its effect on profit of dairy farms was not assessed. Instead, simulations were run to evaluate the proper inclusion rate of corn stover silage in the rations of dairy cows to maximize the profit of dairy farmers and to retain the optimal amount of corn grain for 


\section{CHAPTER 6}

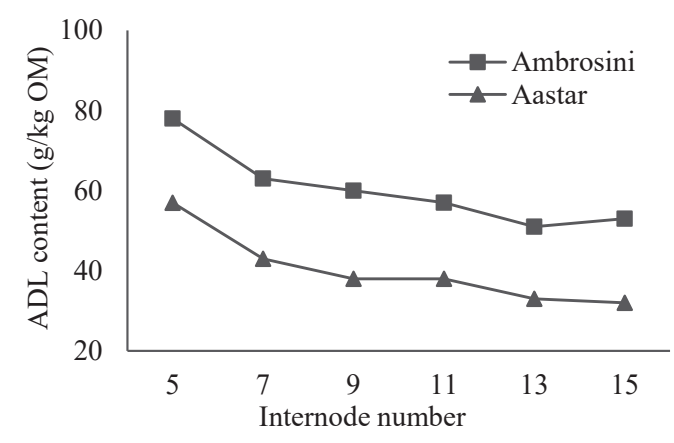

Figure 6.1 The acid detergent lignin (ADL) content on an organic matter (OM) basis of different internodes of two corn cultivars.

other purposes, such as food for human consumption and feed for monogastric animals. The reasons why the selected fungi species and strains (strain MES11910 of LG30211 and strain MES12975 of MZP8057) treatment did not improve the nutritional value of the lower corn stem of LG30211 and MZP8057 will be discussed, followed by a discussion on whether it is financially attractive to apply a fungal treatment of corn stover in dairy farms in case fungal treatment would be able to increase the degradation of corn stover.

\subsection{Fungal treatment}

Fungal treatment, which was used to increase the degradability of the lower part of corn stems, has been shown to improve the degradability of crop residues, such as wheat straw, wood chips, rice straw, oil palm fronds and sugarcane bagasse, due to the process of delignification by the fungi (Tuyen et al., 2012, 2013; Van Kuijk et al., 2015a, 2016b, 2017). It was expected that the two selected fungal species (Lentinula edodes and Pleurotus eryngii) could degrade lignin and increase the degradability, which was evaluated by the IVGP technique, of the lower part of the corn stem. However, this hypothesis was not confirmed, as reflected by the elevated ADL content and decreased IVGP of the substrates that were treated with both fungal species for 3, 6 and 9 weeks, 
in contrast to the untreated substrates (Chapter 4). The ratio of ADL to potentially rumen degradable fiber (pRDF, the sum of hemicellulose and cellulose; ADL:pRDF) increased after a fungal treatment (Chapter 4), indicating that the utilization rate of pRDF is faster than the degradation rate of ADL by both fungal species. A minimized use of pRDF and a maximized degradation of lignin by fungi, which are the guarantee of a successful fungal treatment, may be achieved by selecting proper fungal species and strains. The chemical composition of the untreated corn stem may also influence the effectiveness of the fungal treatment. The changes in fungi or substrates may enhance the fungal treatment and these optimization strategies will be discussed here.

\subsubsection{Proper fungal species and strains}

Over the past decades, more than 40 fungal species have been selected to treat crop residues, among which wheat straw is the most treated substrate (Nayan et al., 2018a). Ceriporiopsis subvermispora is the most used species to improve the degradability of crop residues, followed by L. edodes, Pleurotus ostreatus and P. eryngii (Nayan et al., 2018a). Different fungal species behave differently when they are applied to treat diverse biomasses. Tuyen et al. (2012) investigated the capability of 11 fungal species to degrade lignin and to increase the degradation of wheat straw and found that only three species are able to improve the IVGP within $72 \mathrm{~h}$, which represents the organic matter (OM) degradability, with C. subvermispora being the most effective species in increasing the degradation, followed by $L$. edodes and P. eryngii. The degradability of sugarcane bagasse can be improved by $C$. subvermispora and L. edodes, but not by $P$. eryngii and $P$. ostreatus (Tuyen et al., 2013). For rice straw, $C$. subvermispora and $P$. eryngii are able to improve the degradability while $P$. ostreatus and $L$. edodes cannot (Tuyen et al., 2013). Although the degradability of wood chips and sugarcane bagasse are reported to be improved by the investigated fungal species, these species differed in degrading lignin and the utilization of other carbohydrates, which lead to a varying degree of improvement in degradation (Tuyen et al., 2013; Van Kuijk et al., 2015a). As mentioned above, C. subvermispora is one of the most effective and selective lignin degraders. However, C. subvermispora was not selected to improve the degradability of the lower part of corn stem in the present work. The major concern is the safety of consuming $C$. subvermispora since this fungal species has not been used in mushroom 


\section{CHAPTER 6}

production (Van Kuijk et al., 2015b). Okano et al. (2009) fed sheep for 14 days rations with untreated bamboo or bamboo treated with C. subvermispora (both $30.3 \%$ on DM basis) with the remainder of the diet being alfalfa hay, wheat bran and soybean meal. Although the total tract digestibility of OM, neutral detergent fiber (NDF) and acid detergent fiber (ADF) of the fungal treated bamboo ration was higher than the untreated bamboo ration, it is still unknown if the animals remained healthy after long term feeding with $C$. subvermispora and if the animal products (milk and meat) are not harmful to humans. Hence, in Chapter 4, two species which have already been used in mushroom production (Mattila et al., 2001; Sonnenberg et al., 2016) and are also effective and selective lignin degraders, viz. L. edodes and P. eryngii, were used to treat the lower part of the corn stem.

Not only the fungal species, but also different strains within a species can result in differences in fungal treatment of crop residues, as shown by Nayan et al. (2017, 2018c). MES 11910 from L. edodes is widely applied to treat crop residues (Tuyen et al., 2012, 2013; Van Kuijk et al., 2015a). Nayan et al. (2018c) evaluated the variation among 10 strains which belong to $L$. edodes to select the most suitable strain to improve the nutritional value of wheat straw. The strain MES11910, which was used in the study, proved to be one of the best strains within L. edodes to increase the degradability of wheat straw (Nayan et al., 2018c). Sonnenberg et al. (2016) assessed the ability of 20 strains of $P$. eryngii to remove lignin in wheat straw and enhance the accessibility of hemicellulose and cellulose to rumen microorganisms. The ADL content and ADL:pRDF in wheat straw were found to decrease to the lowest value, and the IVGP within $72 \mathrm{~h}$ reached one of highest values, after incubation with MES12975 of $P$. eryngii for 9 weeks (Sonnenberg et al., 2016). Although Tuyen et al. (2012) incubated corn stover with MES03757 of P. eryngii, which showed the potential to increase the degradability of corn stover, MES12975 was selected since MES12975 performed better than MES03757 in degrading lignin in wheat straw (Sonnenberg et al., 2016). Even though $L$. edodes is capable to degrade lignin and increase the degradability of various crop residues and $P$. eryngii has the potential to improve the IVGP of corn stover, the two fungal species may not be the most suitable species to treat the corn stem. In the biofuel industry, it has been shown that C. subvermispora (Wan and Li, 2010), Cyathus stercoreus (Saha et al., 2016), Irpex lacteus (Xu et al. 2010), Phlebia brevispora, Pycnoporus sanguineus (Saha et al., 2016) and Trametes hirsute yj9 (Sun 
et al., 2011) can improve the sugar yield after incubation of corn stover. However, when feeding the fungal treated crop residues to animals, the animals should remain healthy and the products of the animals should be safe for human consumption. It is uncertain if these fungi species are safe to be consumed. Ma and Ruan (2015) suggested that a co-cultivation by Coprinus comatus and Trichoderma reesei can result in greater sugar yield from corn stover compared with a single fungi species. The reason is that $C$. comatus is an excellent producer of laccase, which is one of the main enzymes secreted by fungi to degrade lignin, whilst $T$. reesei is a well-known commercial enzyme (hemiand cellulolytic enzymes) producer, and they are compatible with each other. In future research, other fungal species and strains, and co-cultivation systems are worth further research and the safety issues should be considered.

\subsubsection{The substrate}

The lower part of corn stems, which was identified as the least degradable part of corn stover (Chapter $\mathbf{2}$ and $\mathbf{3}$ ), was treated with fungi. It was expected that the ADL content in the lower part of the stem decreased and the degradability increased by the fungal treatment. However, the results were the opposite, with increased ADL content and decreased IVGP of the lower part of the stem after a fungal treatment for 9 weeks (Chapter 3). The ADL content of the lower part of the stems of LG30211 and MZP8057 was $4.9 \%( \pm 0.15 \%)$ and $6.7 \%( \pm 0.16 \%)$ on an OM basis, respectively. Given that the OM of both LG30211 and MZP8057 was 97.6\%, the ADL content expressed on a DM basis would be $4.8 \%$ and $6.5 \%$, respectively (Chapter 3). The ADL/pRDF of the lower stems of LG30211 and MZP8057 was 6.3 and 9.3, respectively. Crop residues are characterized by a high ADL content. The ADL content of wheat straw varied from 6.7 to $10.5 \%$ on a DM basis (Tuyen et al., 2012; Khan et al., 2015; Van Kuijk et al., 2015a, 2017; Niu et al., 2018). The rice straw used in the studies by Jafari et al. (2007), Tuyen et al. (2012) and Khan et al. (2015) contained 9.6, 6.2 and 13.5 \% ADL on a DM basis. The sugarcane contained 10.5 to $11.4 \%$ ADL on a DM basis (Okano et al., 2006; Tuyen et al., 2013). The ADL content of most investigated crop residues are greater than that of the stems used in the present study. Tuyen et al. (2013) successfully improved the degradability of rice straw with an ADL content and ADL/pRDF of $6.2 \%$ on a DM basis and 8.5, respectively, by using C. subvermispora and P. eryngii. 


\section{CHAPTER 6}

However, the degradation of rice straw only increased by 12.3 and $9.6 \%$ after 6 weeks of treatment with C. subvermispora and P. eryngii, respectively (Tuyen et al., 2013). Karunanandaa et al. (1995) treated rice stems (ADL content 5.4\% of DM and ADL/pRDF 7.2) with Pleurotus sajor-caju for $30 \mathrm{~d}$ and reported a $11.1 \%$ improvement in degradation. In contrast, Van Kuijk et al. (2015a) failed to improve the degradability of rice straw which contained 3.6\% ADL on a DM basis by using C. subvermispora, $P$. eryngii and L. edodes. It is speculated that for the rice straw with a low ADL content, lignin degradation is not required to obtain nutrients for fungal growth (Van Kuijk, 2016a). Lynch et al. (2014) incubated corn stems (ADL content 4.7\% of DM and ADL/pRDF 6.8) with P. ostreatus and Trametes versicolor and the degradability was not enhanced after the fungal treatment. Khan et al. (2015) successfully improved the degradation of corn stover which contained $15 \%$ ADL on a DM basis by incubation with P. ostreatus. In the biofuel industry, the ADL content of corn stover varied from 13.7 to $20.2 \%$ on a DM basis (Wan and Li, 2010; Sun et al., 2011; Saha et al., 2016). Collectively, the degradability of corn stems with a low ADL content and ADL/pRDF is difficult to improve by a fungal treatment. Perhaps the ADL content and ADL/pRDF ratio can be used as an indication to show whether a fungal treatment can decrease the ADL content and improve the rumen degradation successfully.

\subsubsection{Measuring cell wall content and its degradability}

The Weende method is the first method to quantify the amount of cell walls, which is known as crude fiber, in animal feedstuffs (Henneberg and Stohman, 1859). During the determination procedures, the samples are treated in sulfuric acid and sodium hydroxide at elevated temperatures. However, this procedure can result in a majority of noncellulosic polysaccharides with part of the lignin being lost, which is the main flaw of this method. To determine the cell wall components more accurately, Van Soest (1963a, b) introduced the use of detergents in the fiber analysis. In the research of dairy cattle nutrition, the detergent methods are commonly accepted and used. The NDF content is the sum of hemicellulose, cellulose and lignin and the ADF content consists of cellulose and lignin. The ADL content is used to represent the amount of lignin in the cell walls. Although there are some non-cellulosic polysaccharides dissolved during the analytical procedures, the NDF content is still considered as a rapid method to estimate the cell 
wall content since precise quantifying the cell wall content is difficult.

There are several methods to measure the NDF degradability in dairy cows. One of the methods is the in vivo method to measure NDF degradation kinetics using the rumen evacuation technique (Taylor and Allen, 2005; Huhtanen et al., 2007). This technique is regarded as an ideal method for estimating digestion rate (Huhtanen et al., 2006), although it is time-consuming, expensive and laborious, making it impossible to be used as a routine analysis. The in situ method is an alternative for the in vivo method. Briefly, samples are weighed into nylon bags with a certain mesh size, allowing the rumen microorganisms to pass to the inside of the bag and to degrade the feedstuffs. The nylon bags are inserted into the rumen and incubated for certain periods. There should be several incubation periods to calculate degradation kinetics of components. This method is also laborious, because for one feedstuff, there are many samples needed to be analyzed considering the time points for incubation, cows needed and duplicated or triplicated nylon bags needed for one single time point in one cow's rumen. Besides, there are several questions that cannot be resolved completely, such as the issue that not all the substrate that leaves the bag has actually been degraded, and some of the residue remaining in the bag is not really undegradable matter of feed origin (Mertens, 1993). Other issues relate to the lower bacterial population, particularly the cellulolytic bacterial population, inside the bags relative to populations in the surrounding digesta (Meyer and Mackie, 1986) and the lower $\mathrm{pH}$ in the bags than in the rumen digesta (Noziere and Michalet-Doreau, 2000). There are two in vitro methods developed to measure NDF degradation, known as in vitro NDF degradability and IVGP to predict NDF degradability. The in vitro NDF degradability was first described by Goering and Van Soest (1970), modified from the Tilley and Terry (1963) two-stage digestion in vitro DM digestion technique. Usually, a single time point (typically 24,30 or $48 \mathrm{~h}$ ) is used to determine the in vitro NDF degradability (Oba and Allen, 1999b), which should not be used to compare NDF degradability across forage types or between labs (Combs, 2013). However, the degradability value calculated from the single time point only suggest how much NDF is left after certain incubation hours in rumen fluid and this method does not segregate the indigestible NDF from the residue NDF nor does it reflect the degradation rate of NDF (Combs, 2013). Another in vitro method used to evaluate NDF degradation is the IVGP technique (Cone et al., 1996). By using a threephasic model, Cone et al. (1997) suggested that the gas production between 3 and $20 \mathrm{~h}$ 


\section{CHAPTER 6}

(second sub-curve of the total gas production curve) represents the fermentation of the non-soluble part of the substrate, which is the cell wall degradation when the substrate is a forage. Furthermore, Cone et al. (1998) demonstrated that the in situ degradation rate of NDF was correlated with the time at which half of the IVGP of the non-soluble fraction is reached which represents a measure of the degradation kinetics $\left(R^{2}=0.68\right)$. When fitting the second subcurve with the exponential model of Robinson et al. (1986), the degradation rate of the second subcurve of gas production has a stronger correlation $\left(\mathrm{R}^{2}=0.83\right)$ with the in situ degradation rate of NDF (Cone et al., 1998). However, due to the shortcomings of the in situ method mentioned above, the effective degradability of NDF calculated by the in situ method was not correlated with the IVGP between 3 and $20 \mathrm{~h}$ (Cone et al., 1998). It is possible that the IVGP technique may be more accurate than the in situ method (Huhtanen et al., 2006). However, the latter authors stated that comparing different kinetic methods (in vitro vs. in situ) may be of little value before the accuracy of these methods has been improved. The degradation of NDF in the rumen of dairy cows is the result of the integration of degradable NDF, degradation rate and passage rate. Since the passage rate is primarily influenced by the level of DM intake (DMI), which can be affected by NDF degradation (Oba and Allen, 1999b), and since there may be a difference in $\mathrm{pH}$ between the rumen and the IVGP system where two parts of buffer are mixed with one part of rumen fluid, it may also be meaningless to correlate the IVGP with the in vivo ruminal NDF degradability. However, the IVGP method can help to rank the forages. Considering the number of samples, convenience, time, cost and accuracy of the methods, the IVGP technique is a preferable method to quantify the NDF degradation.

\subsubsection{Potential benefits of effective fungal treatment}

In general, when the fungal treatment succeeds to improve the degradability of crop residues, the ADL and hemicellulose content decrease and the crude protein content increases. When the degradability of the crop residues increases after a fungal treatment, they can provide more metabolizable energy (ME) to the dairy cow. Meanwhile, the loss of DM during the fungal treatment and the cost to apply the fungal treatment should be considered. It is of interest to investigate whether the fungal treatment can benefit the profit of dairy farmers. However, in Chapter 4 it was shown that $P$. eryngii and $L$. 
edodes did not improve the degradation of the lower part of the corn stem. It is unknown, to what extent the nutrient composition of corn stem can change after a successful fungal treatment. Therefore, assumptions on how the nutrient composition changes after a fungal treatment have to be made.

A primary interest of this thesis was to improve the degradation of the lower part of the corn stem, which is the least degradable part of corn stover, by a fungal treatment, and to evaluate whether it is economical to separate the lower part of corn stems from the total corn stover, followed by a treatment with fungi to improve the nutritional value of the lower stem. Nevertheless, since the objective of this section is to evaluate the effect of the fungal treatment on the profit of dairy farmers, for simplicity, it will be evaluated if the fungal treatment of corn stover, rather than the lower part of the corn stem, which should be separated from corn stover before fungal treatment, can increase the profit of dairy farmers. According to the ME value which was predicted by chemical composition (NRC, 2001), corn stover silage (CSS) of Rivaldinio had the lowest ME among the four corn cultivars (Chapter 5). Therefore, corn stover of Rivaldinio was chosen to evaluate a hypothetical successful treatment with fungi to improve its degradability.

\subsubsection{Model development}

In Table 6.1, the chemical composition (ADL, ADF, NDF and crude protein (CP) on a DM basis) of wheat straw, rice straw and sugarcane bagasse, which were reported to be the top 3 substrates that were treated by fungi to increase their degradability in the rumen (Nayan et al., 2018b), before and after the fungal treatment are shown, as well as the DM loss and the changes in ADL, ADF, NDF, CP and degradability during the fungal treatment. Ten studies which were published in peer-reviewed journals were selected. Among the 10 studies, 5, 3 and 2 studies used wheat straw, rice straw and sugarcane bagasse as substrate, respectively. On average, the DM loss after the fungal treatment was $15.4 \%$, the decrease in ADL and NDF content was $46.4 \%$ and $18.0 \%$, respectively, and the increase in $\mathrm{CP}$ content, $\mathrm{ADF}$ content and $\mathrm{OM}$ degradability was $54.4 \%, 2.3 \%$ and $34.1 \%$, respectively. The decreased hemicellulose content (46.3\%) after the fungal treatment is likely caused by the utilization by the fungi as an energy source. The increased CP content may be the result of the relative degradation of 


\section{CHAPTER 6}

hemicellulose, ADL and other easily accessible carbohydrates by the fungi (Nayan et al., 2018b), hence the ether extract and ash content were assumed to increase by $54.4 \%$ after the fungal treatment. Nayan et al. (2018b) investigated the CP degradability of fungal treated wheat straw and found that $C$. subvermispora did not change the $\mathrm{CP}$ degradability of the substrate while $P$. eryngii and $L$. edodes increased the CP degradability. For simplicity, the CP degradability was assumed to be constant before and after the fungal treatment.

After harvesting, corn stover will be treated with fungi, followed by preservation. Mao et al. (2018) reported that the fungal treated wheat straw can be preserved under anaerobic conditions, as the fungi reduce the $\mathrm{pH}$ to 3.6-3.8, without additives up to 2 months and the chemical composition of the fungal treated wheat straw did not change during the 2-months preservation. It is assumed that the fungal treated corn stover can also be conserved without additives and no changes of chemical composition occurs during the preservation.

The DM content of whole plant corn silage (WPCS) and CSS was reported to be influenced by the length of storage on dairy farms (Yan et al., 2009a, b). However, Der Bedrosian et al. (2012) found that the DM content of WPCS at dairy farms only slightly changed during $180 \mathrm{~d}$ of ensiling. Kristensen et al. (2010) found that the DM content of WPCS collected from dairy farms was not influenced by the ensiling period. The DM content of corn stem silage decreased after 8 weeks of ensiling (He et al., 2019), but the stem was ensiled in glass jars with no water exchange and the decreased DM content may be explained by the utilization of water soluble carbohydrates by the microorganisms during the ensiling (He et al., 2019). The effect of ensiling on the NDF content of WPCS was not consistent in previous studies where the NDF content of WPCS increased (Yan et al., 2009a), decreased (Herrmann et al., 2011), or was not affected by the length of ensiling (Sanderson, 1993; Der Bedrosian et al., 2012). Der Bedrosian et al. (2012) found that the ADL and ADF content of WPCS was not influenced by the ensiling period. The $\mathrm{CP}$ content of non-brown midrib hybrid increased while that of brown midrib hybrid did not change after ensiling (Der Bedrosian et al., 2012). Collectively, the chemical composition of corn stover during ensiling was assumed to be constant. Therefore, the chemical composition of corn stover was the same as the chemical composition of CSS, which was reported in 
CHAPTER 6

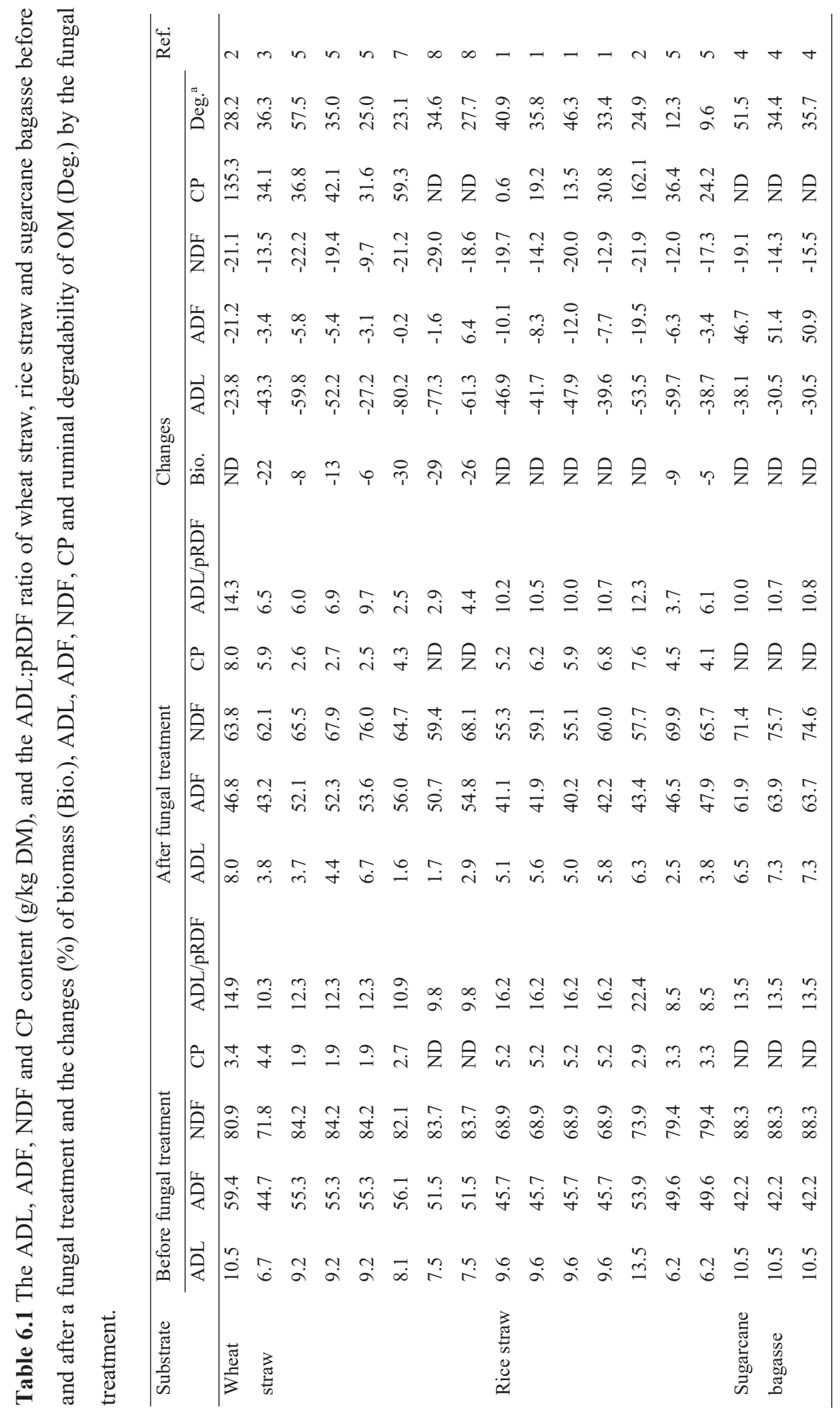


CHAPTER 6

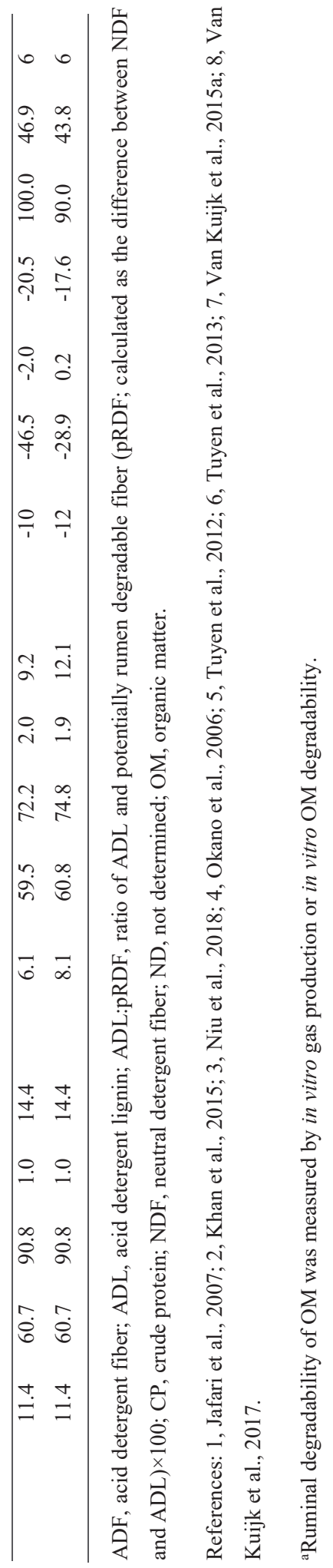


Chapter 5, although the chemical composition of the corn stover was not analyzed.

It is assumed that the fungal treated corn stover had no negative influence on the DMI and performance of the dairy cows. The cost to apply fungal treatment on dairy farms was not taken into account to calculate the profit of the dairy farms since it is difficult to make assumptions on the costs, as this is a new technology. Alternatively, the profit of the farm where the untreated corn stover was fed to dairy cattle and the one that used fungal treated corn stover was compared. When the difference in profit between the two farms is larger than the cost of the fungal treatment, the farmers may choose to use fungi to treat the crop residues.

In the NRC (2001), the digestible energy (DE) of a feedstuff at maintenance level is predicted by the chemical composition, such as CP, NDF, ether extract (EE), ADL, etc., and the metabolizable and net energy (NE) is predicted from the DE of the feedstuff. With the changes in chemical composition during the fungal treatment, the DE, ME and $\mathrm{NE}$ of corn stover changed after the fungal treatment. It has been demonstrated that lignin is negatively correlated with the degradability of crop residues due to the linkages between lignin and other carbohydrates. After lignin modification or removal, the rumen microorganisms can get access to these carbohydrates. Van Kuijk et al. (2015a) found that the in vitro gas production after $72 \mathrm{~h}$ of wheat straw, miscanthus, and wood chips increased 9.1, 16.7 and $14.9 \mathrm{ml} / \mathrm{g} \mathrm{OM}$, respectively through decreasing the ADL content by $10 \mathrm{~g} / \mathrm{kg} \mathrm{DM}$, indicating that the linkages between lignin and carbohydrates varied among different crop residues. However, these linkages were not taken into consideration to predict the DE of crop residues (NRC, 2001). The DE at maintenance level of untreated and fungal treated corn stover of the corn cultivar Rivaldinio, calculated using the NRC prediction equation, was 10.13 and $11.21 \mathrm{MJ} / \mathrm{kg} \mathrm{DM}$, and the fungal treatment increased the DE of corn stover by $10.7 \%$, which may be underestimated. In contrast, the degradability of crop residues after a fungal treatment increased by $34.1 \%$ on average, which was evaluated by the IVGP within $72 \mathrm{~h}$ or in vitro OM degradability, as shown in Table 6.1. Jancik et al. (2011) found that the IVGP within $72 \mathrm{~h}$ of grass and grass silage was highly correlated $\left(\mathrm{R}^{2}=0.95\right)$ with their OM degradability determined using pepsin-cellulase solubility, which was demonstrated to be correlated $\left(\mathrm{R}^{2}=0.97\right.$ and 0.85 for primary growth and regrowth grass, respectively) with in vivo OM degradability of grass and grass silage (Huhtanen et al., 2005). According to Moir (1961) who reported that the DE of the diets for cattle and sheep 


\section{CHAPTER 6}

Table 6.2 Assumptions related to fungal treatment of corn stover (CS), used in model simulations.

\begin{tabular}{|c|c|}
\hline Assumptions & References $^{\mathrm{a}}$ \\
\hline $\begin{array}{l}\text { During fungal treatment: DM loss, } 15.4 \% \text {; decrease in ADL and NDF content, } \\
46.4 \% \text { and } 18.0 \% \text {, respectively; increase in CP, ADF and OM degradability, } \\
54.4 \%, 2.3 \% \text { and } 34.1 \% \text {, respectively }\end{array}$ & - \\
\hline $\begin{array}{l}\text { Ruminal degradability of RDP from CS was the same before and after fungal } \\
\text { treatment }\end{array}$ & Nayan et al., $2018 \mathrm{~b}$ \\
\hline $\begin{array}{l}\text { Fungal treated CS can be preserved anaerobically, without changes in } \\
\text { chemical composition }\end{array}$ & Mao et al., 2018 \\
\hline No changes in chemical composition before and after ensiling & - \\
\hline $\begin{array}{l}\text { Two values of DE at maintenance level of fungal treated CS were used: } 10.7 \% \\
\text { and } 34.1 \% \text { increase compared with untreated CS }\end{array}$ & - \\
\hline
\end{tabular}

ADF, acid detergent fiber; ADL, acid detergent lignin; CP, crude protein; DE, digestible energy; DM, dry matter; NDF, neutral detergent fiber; OM, organic matter; RDP, rumen degradable protein.

${ }^{a}$ When the references are not shown, see section 6.1.4.1 Model development.

were highly correlated with the DM digestibility of the diets in a wide range of DMI and DM digestibility, and since ash does not provide energy for dairy cows, the DE is expected to be related with the OM digestibility. Collectively, it can be speculated that the $34.1 \%$ increment in the degradability of fungal treated crop residues may lead to $34.1 \%$ increase in the DE of fungal treated crop residues. Since there was no in vivo trial conducted to determine the DE, ME and NE of fungal treated corn stover, it is not clear which value of DE is more accurate. Therefore, when evaluating the effect of applying a fungal treatment on corn stover on corn saved for other purposes and profit for dairy farmers, two values of DE at maintenance level of fungal treated Rivaldinio (FTR) were used; one is predicted by the chemical composition based on NRC (2001) while the other is arbitrarily increased by $34.1 \%$ based on the value of untreated Rivaldinio.

The model in Chapter 5 was run to obtain the relevant results when WPCS and corn stover (without fungal treatement) silage were fed to dairy cows. Next, the data on FTR replaced the data on corn stover (without fungal treatment) silage, to obtain the relevant 
results when WPCS and FTR were fed to dairy cows. Assumptions as to fungal treatment of corn stover are summarized in Table 6.2.

\subsubsection{Model results and discussion}

The diet composition for dry cows (milk yield $0 \mathrm{~kg} / \mathrm{d}$ ) during 60 days and lactating cows producing 10, 20 and $30 \mathrm{~kg}$ milk/d during 305 lactating days when $0,25,50,75$ and $100 \%$ of plants are harvested as corn stover and treated by fungi before preservation or harvested as corn stover, but ensiled immediately after harvesting, are shown in Table 6.3. When ground corn (GC) was not included in the ration, the DMI of the cows decreased by replacing untreated Rivaldinio with FTR, due to the greater energy content of FTR and greater portion of WPCS in the ration. With more CSS included in the ration, ground corn has to be added when the NDF content in the ration reached its limit. After ground corn was included in the ration, replacing untreated Rivaldinio with FTR resulted in increased DMI since more FTR which contained less NDF and a greater energy content than the untreated Rivaldinio can be included in the ration, and the energy content of FTR was still less than ground corn. An increase in DE of Rivaldinio by fungal treatment resulted in decreased DMI and a smaller amount of GC required in the diet. When DE content of Rivaldinio increased by $10.7 \%$ after fungal treatment, the proportion of soybean meal in the ration of dairy cows decreased in contrast to the default situation due to the greater CP content in FTR. However, when DE content of Rivaldinio increased by $34.1 \%$ after fungal treatment, the proportion of soybean meal in the ration of dairy cows increased compared with the situation where the DE content of Rivaldinio increased by $10.7 \%$, since the DMI and fraction of ground corn in the ration decreased, leading to a decreased metabolizable protein (MP) intake. The greater proportion of soybean meal in the ration ensures sufficient MP supply from the ration.

The effects of including fungal treated corn stover in the ration of dairy cows on the land area needed, profit for dairy farmers and corn available for other purposes are shown in Table 6.4. For the ration with a high ratio of the plants used for WPCS to those used for CSS (WPCS:CSS), more land area is needed to grow corn plants (as WPCS and CSS) when the degradability of FTR increased by $10.7 \%$ compared with untreated corn stover. The reasons for this increase include DM losses during the fungal treatment and higher CSS inclusion in the ration, while less land area is needed to grow 


\section{CHAPTER 6}

corn plants if the degradability of FTR increased by $34.1 \%$, since the DMI decreased and the improvement in DE can compensate for the DM losses during the fungal treatment. When all the corn plants are used as CSS, the land area needed to grow corn plants increases with the inclusion of FTR in the ration, due to the higher CSS inclusion in the ration. Compared with the situation where the DE content of FTR increases by $10.7 \%$, less land area is needed when DE content of FTR increases by $34.1 \%$. The cost, including machinery, labor, electricity, warehouse and relevant equipment, to apply fungal treatments was not included in the model. Hence, the increased profit for dairy farmers by using FTR should be more than the cost to apply the fungal treatment. When reaching the highest profit for dairy farmers, the maximum cost to apply the fungal treatment is 154, 204, 203 and $207 \mathrm{RMB} / \mathrm{Mg} \mathrm{DM}$ of corn stover for dairy farms with dry cows and cows producing 10, 20 and $30 \mathrm{~kg}$ milk daily, respectively, if the degradability of corn stover increased by $10.7 \%$ by the fungal treatment. When the degradability of corn stover increased by $34.1 \%$, the cost should be no more than 287 , 337,358 and $384 \mathrm{RMB} / \mathrm{Mg} \mathrm{DM}$ of corn stover for dairy farmers with dry cows and cows producing 10, 20 and $30 \mathrm{~kg}$ milk daily, respectively. From the results, it can be concluded that it would be more profitable to apply fungal treatment at dairy farms with cows having a greater milk production. Corn saved for other purposes is another concern in the discussion. The land area needed to grow corn and soybean and total corn available for other purposes when FTR was included in the ration for 100 dairy cows producing 10, 20 and $30 \mathrm{~kg}$ milk daily during 305 lactating days are shown in Table 6.5. When the DE content of FTR increased by $10.7 \%$, the land area needed to grow corn plants and soybeans for dairy farms was the highest compared with the situations when the untreated Rivaldinio and when the DE content of FTR increased by $34.1 \%$ at the three milk production levels; 9.2, 7.3 and 2.4 ha extra land was available for other purposes when the untreated Rivaldinio was fed to the cows producing 10, 20 and $30 \mathrm{~kg} / \mathrm{d}$ milk, respectively, and 6.0,2.8 and 0.2 ha extra land was available for other purposes when the FTR with $34.1 \%$ increase in DE content was fed to the cows producing 10, 20 and $30 \mathrm{~kg} / \mathrm{d}$ milk, respectively. If the extra land was also used to grow corn plants, the total corn available for other purposes was higher when the FTR was fed to cows in contrast to the untreated Rivaldinio. When the milk production was 10 $\mathrm{kg} / \mathrm{d}$, the FTR with $10.7 \%$ increase in DE content saved the largest amount of corn grain. When the milk production was 20 and $30 \mathrm{~kg} / \mathrm{d}$, the FTR with $34.1 \%$ increase in DE content saved the largest amount of corn grain. 


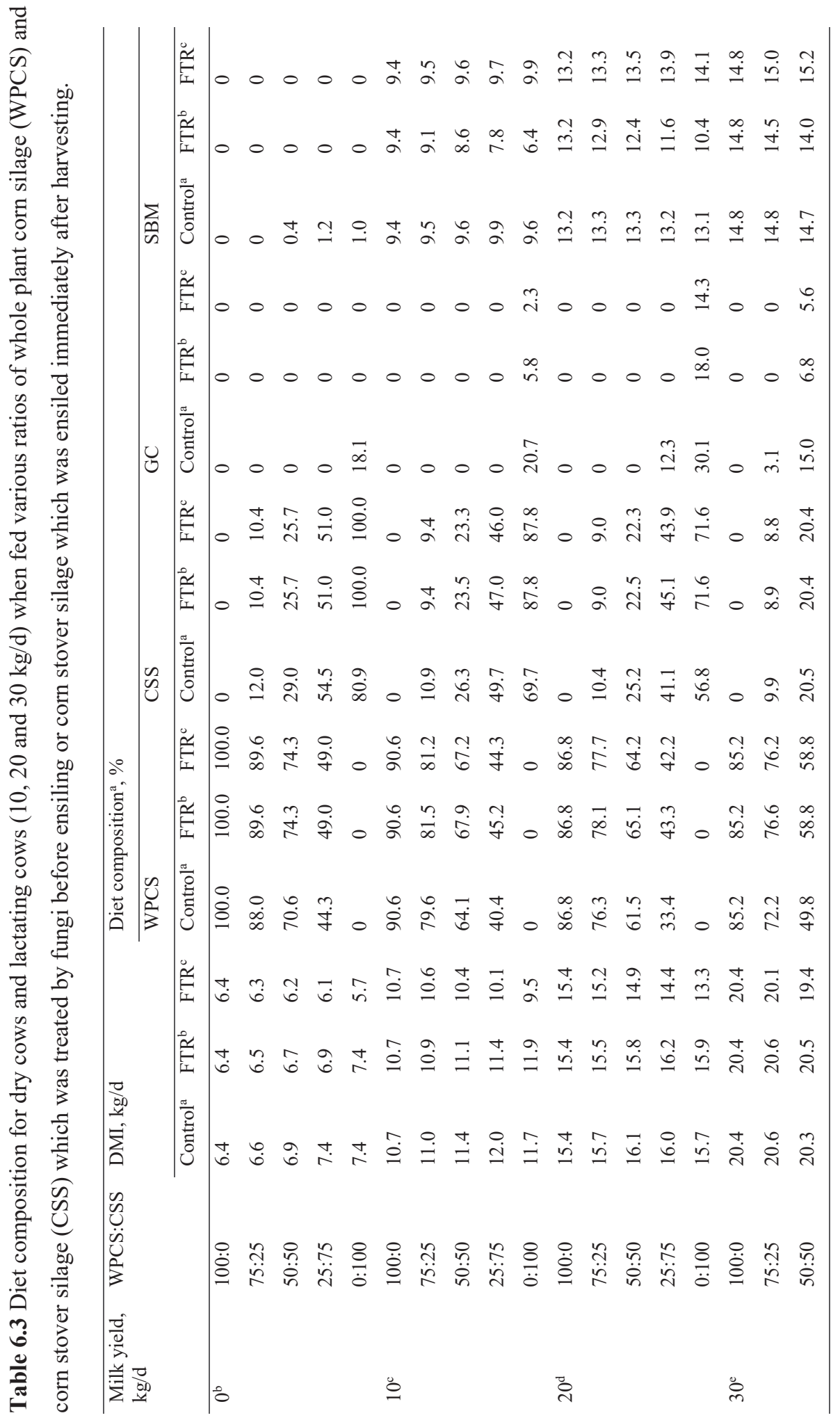


CHAPTER 6

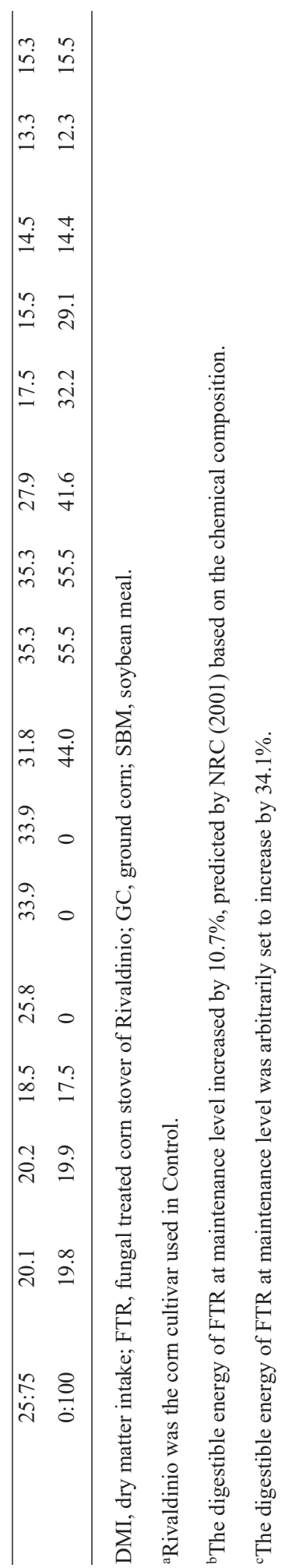


CHAPTER 6

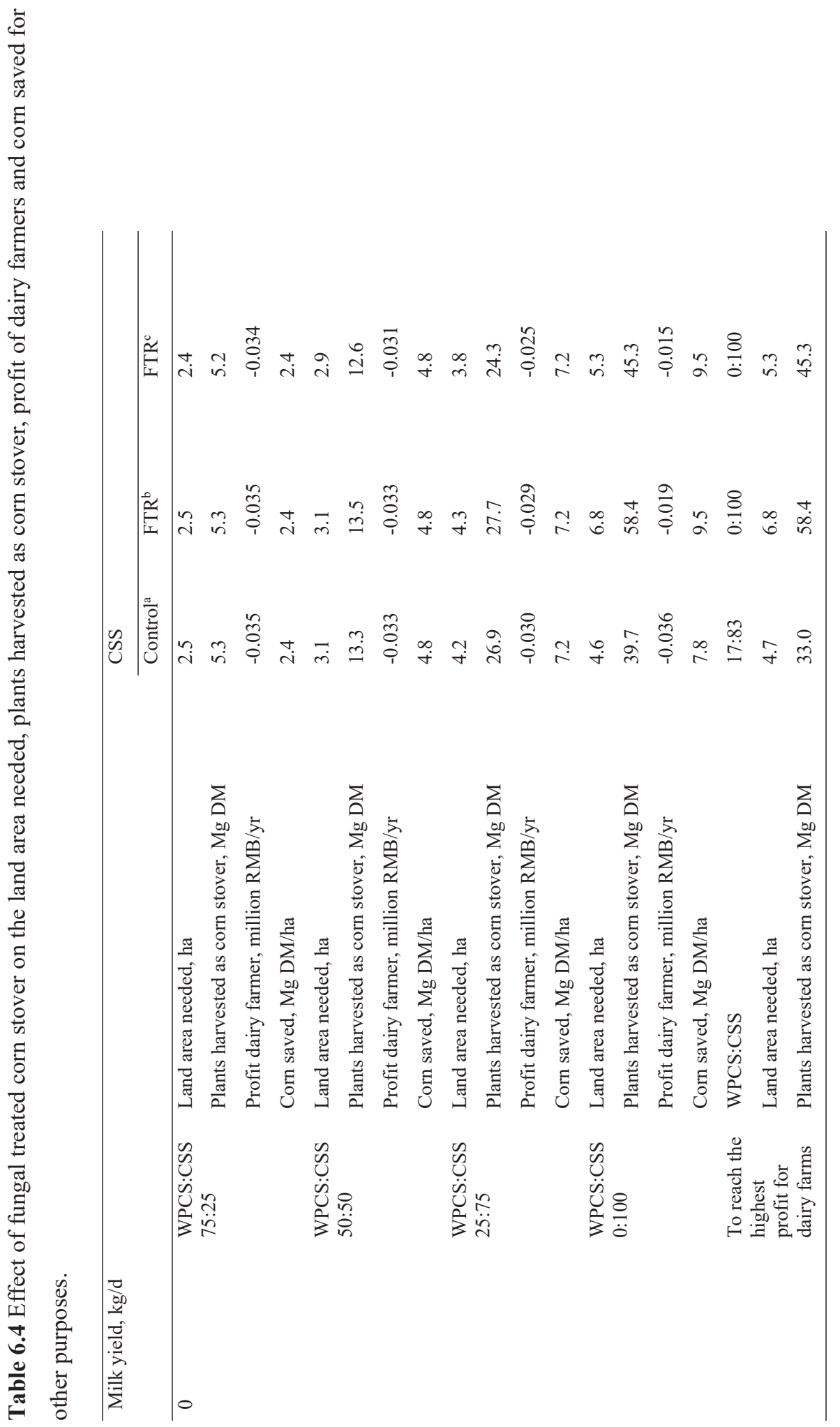




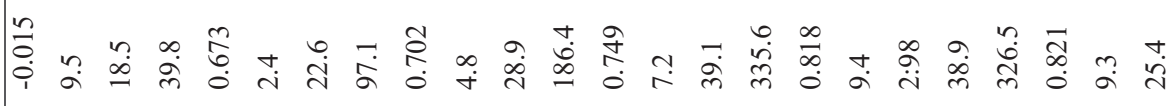

它

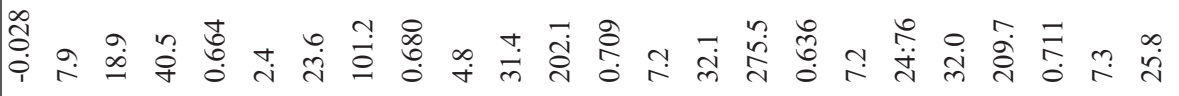

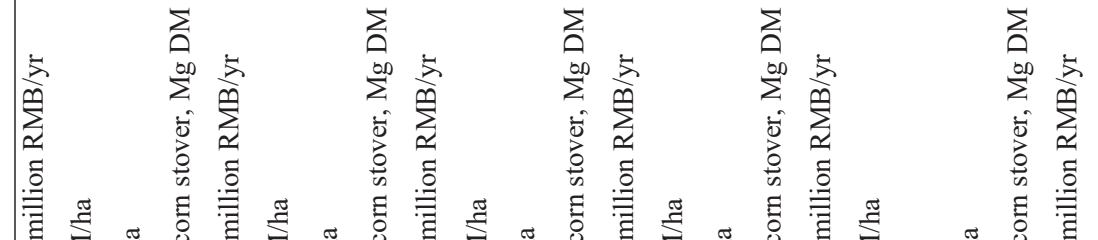

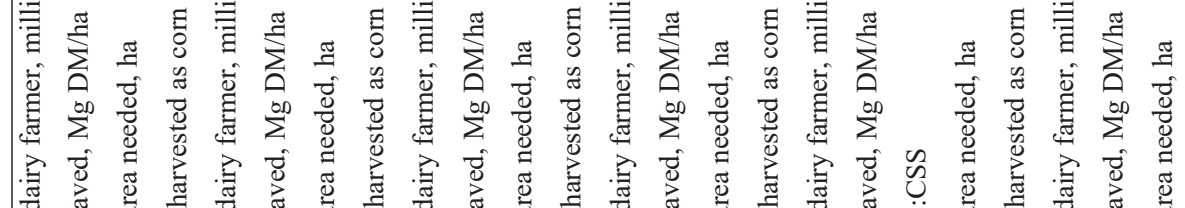

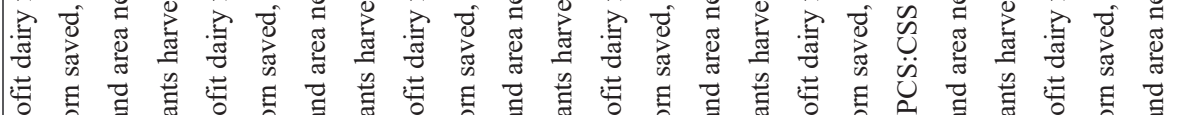

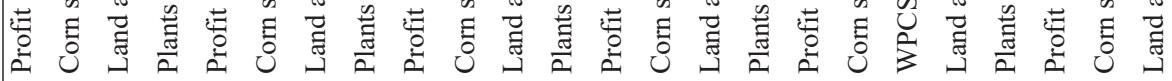

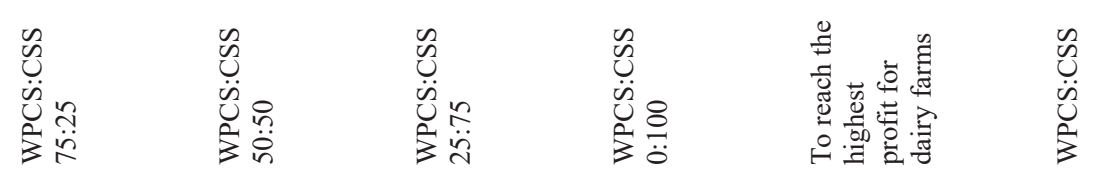

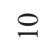

ণิ 


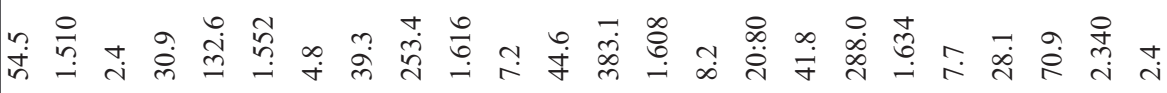

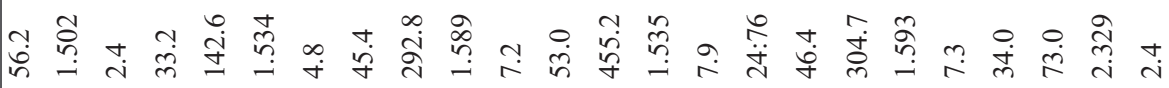

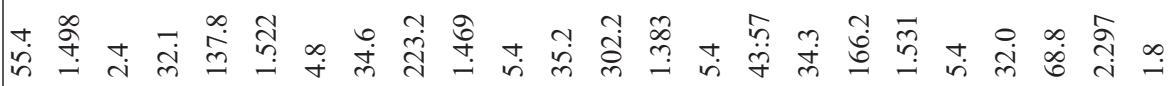

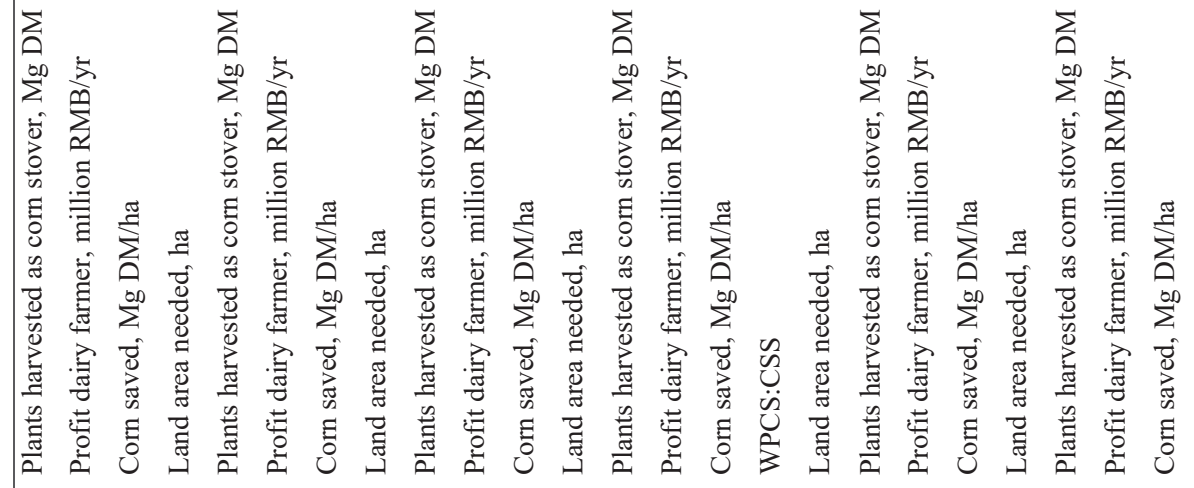

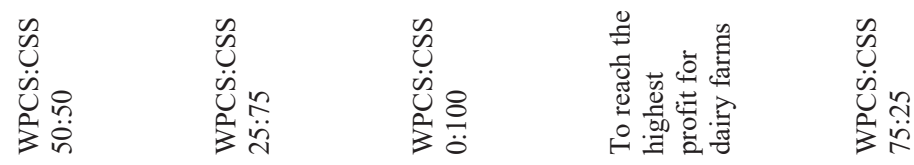

요 


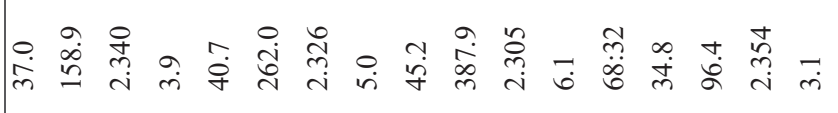

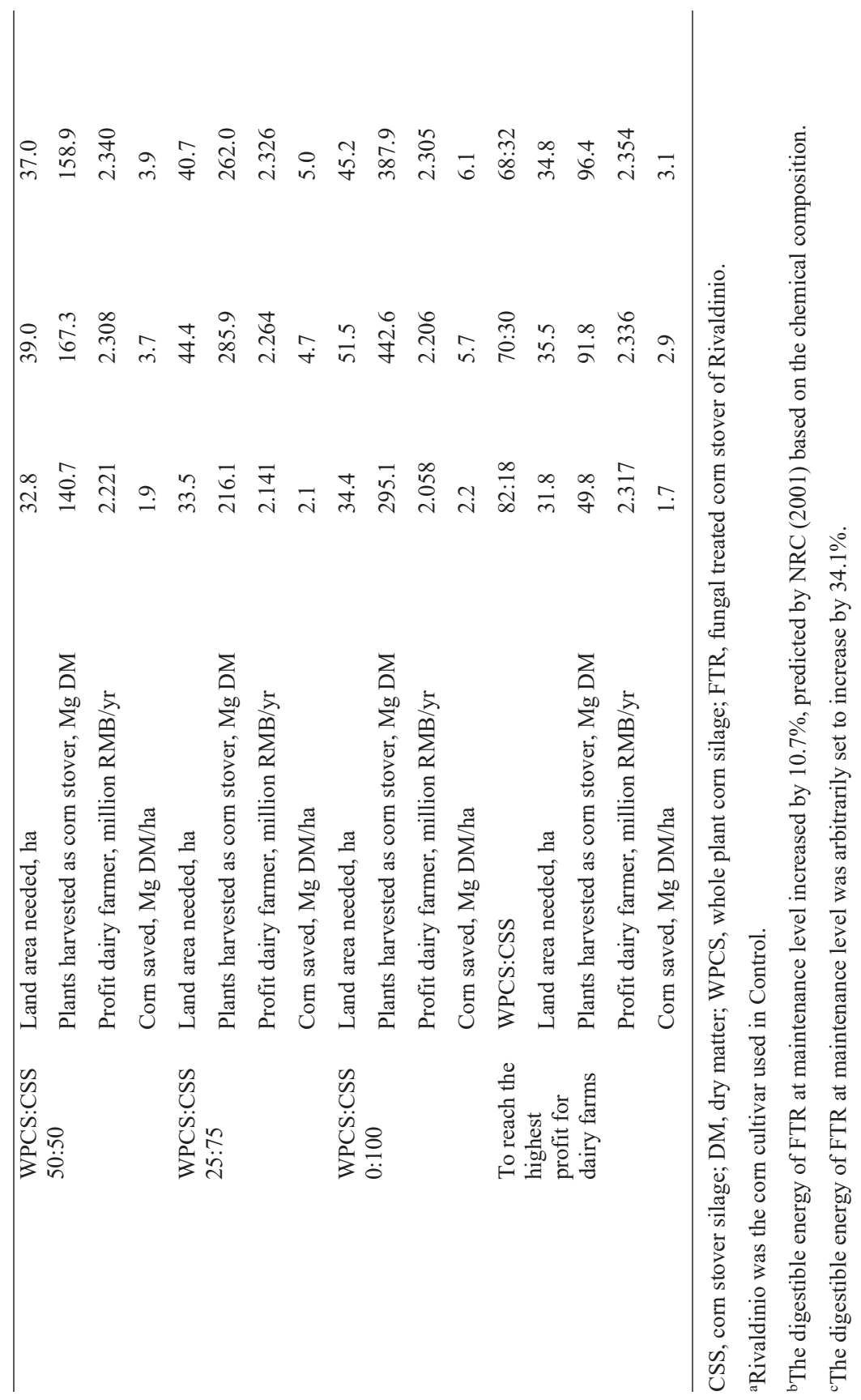


CHAPTER 6

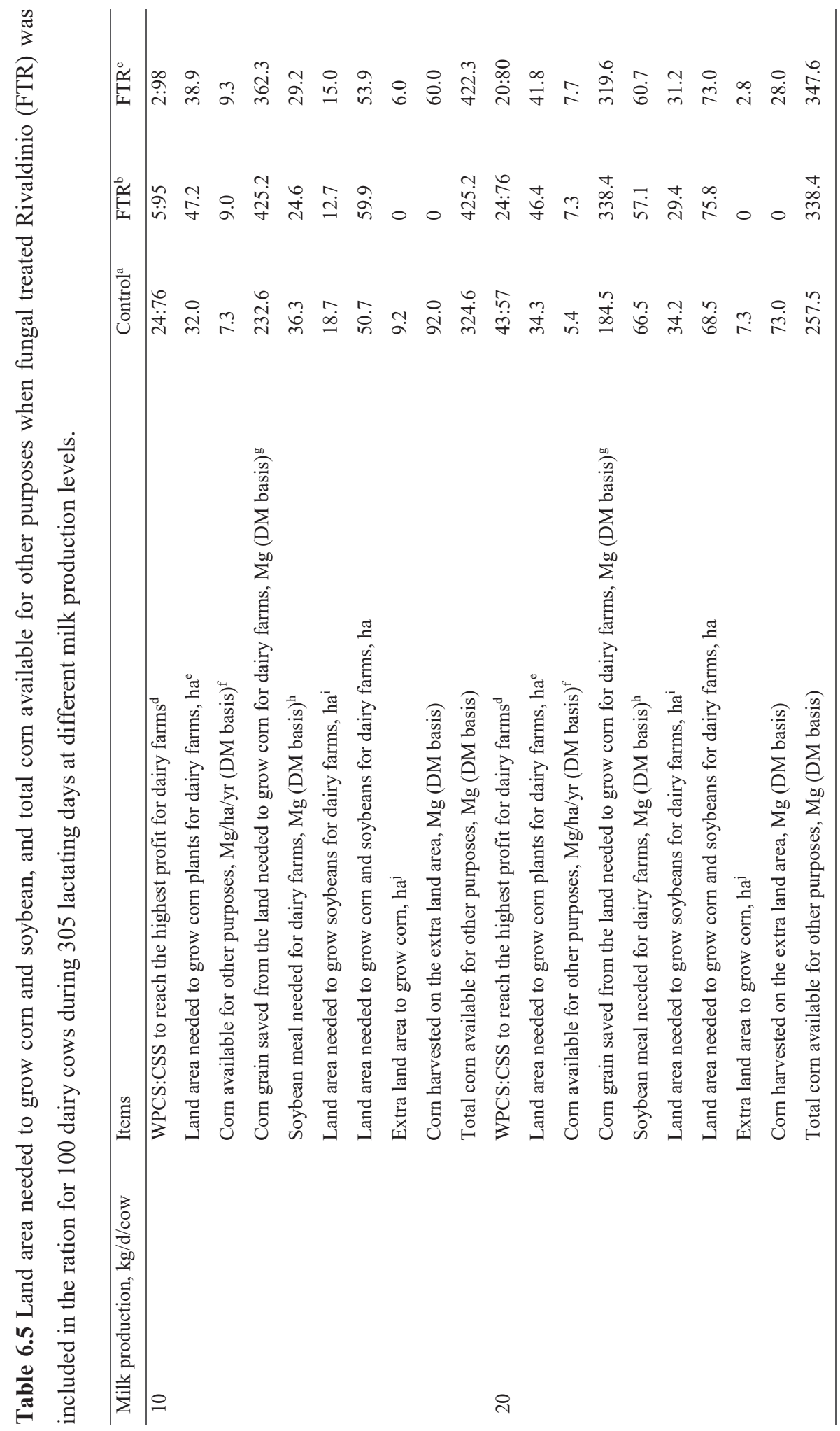




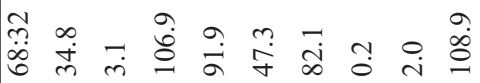

离

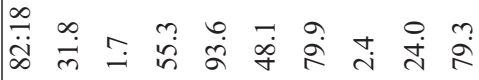

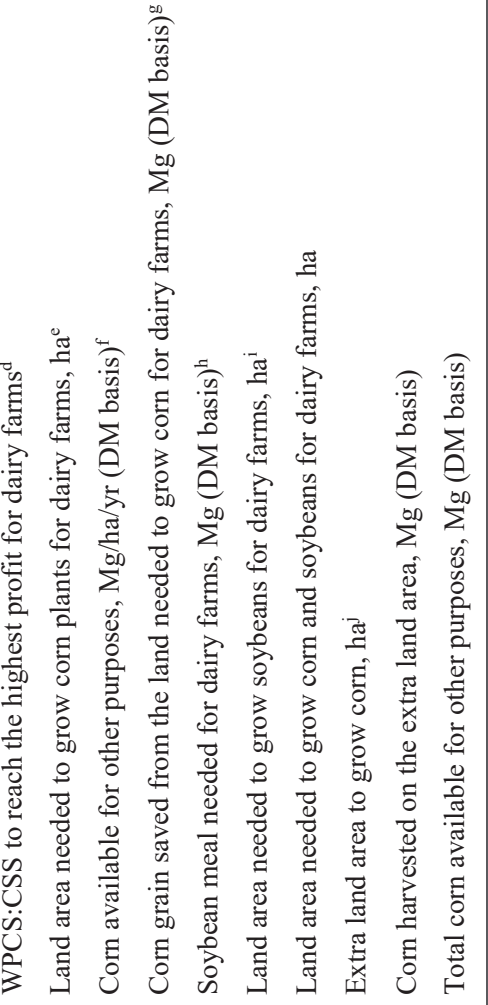

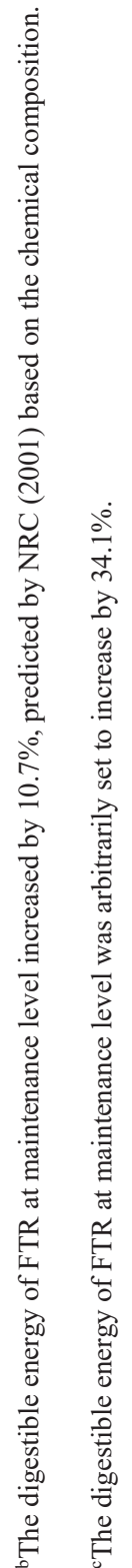

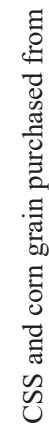

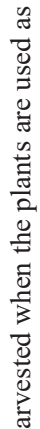

क 
CHAPTER 6

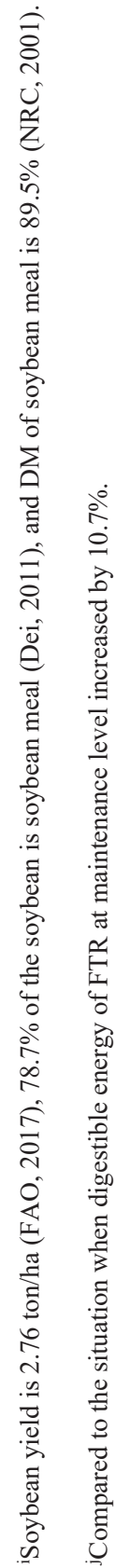




\section{CHAPTER 6}

With the increased milk produced per dairy cow, more ME should be ingested by the cows. More grains are included in the ration of dairy cows with greater milk production, which can be found in Table 6.3 when all the plants were used as CSS. High producing cows with a greater DMI and proportion of starch in the ration are more susceptible to subacute ruminal acidosis (SARA) than low producing cows (Krause and Otzel, 2006). The negative impacts of SARA on dairy farms include decreased DMI, milk yield, profitability, and increased culling rate and death loss (McCann et al., 2016). Currently, SARA is defined based on rumen pH (Kleen et al., 2003; Oetzel, 2003; Stone, 2004; Plaizier et al., 2008) and the duration of the pH under a threshold (Garrett et al., 1999; Plaizier, 2004; Gozho et al., 2005). The reasons that SARA occurs are related to the accumulation of volatile fatty acids and insufficient rumen buffering; the former can be caused by feeding highly fermentable carbohydrates to dairy cows and the later can be the result of less forages in the ration (Plaizier et al., 2008). Generally, the starch from ground corn has greater degradability and degradation rate than the NDF from corn stover (Jensen et al., 2005). Reducing the use of ground corn and increasing the percentage of corn stover in the ration may reduce the incidence of SARA. Based on Mertens (1994), there is a maximum NDF content in the ration for dairy cows, beyond which the DMI of the cows will decrease. Since the physical effective fiber (peNDF) can stimulate saliva secretion to provide buffer for the rumen, there should be enough peNDF but also sufficient readily degradable carbohydrates in the ration for the cows (Zebeli et al., 2012). One solution for this is to provide forages with greater NDF degradability. Oba and Allen (1999a) reported that brown midrib corn silage, which had greater NDF degradability than normal corn cultivars, can improve the DMI of cows and increase milk production. Kendall et al. (2009) found that anhydrous $\mathrm{NH}_{3}-$ treated wheat straw had greater in vitro NDF degradability than untreated wheat straw and can improve the DMI and milk production of cows. However, it should be noted that forages with greater degradability can also contribute more volatile fatty acids to the rumen than the ones with lower degradability, meaning a higher chance for cows to suffer from SARA. Westwood et al. (2003) reported that the increase in the rate of ruminal degradation of NDF from grass (from less than $5 \% / \mathrm{h}$ to more than $14 \% / \mathrm{h}$ ) may also make the dairy cows more susceptible to SARA. It is worth to study whether replacing untreated corn stover with fungal treated corn stover (assuming fungal treatment is effective) can induce the incidence of SARA at different NDF levels in the ration and different milk production levels. 
Collectively, in situations that anaerobic fungi can improve the degradability of corn stover, the profit for dairy farmers increases, more corn can be saved for other purposes, and the cows may be healthier. The latter is, however, dependent on the intake level of rations containing fungal treated corn stover. Currently it is unknown whether the fungal treatment affects DMI.

\subsection{Conclusions and recommendations}

For most corn cultivars, the stems showed a greater cell wall degradability than the leaves. These cultivars are specific for making silage on dairy farms. In China, there are many corn cultivars, which are not only used for silage, but also for human food and animal feed. Investigating the cell wall degradability of stems and leaves from corn cultivars in China is of great interest not only to evaluate if the results obtained for corn silage type cultivars here apply to other corn varieties as well, but more importantly to enable optimization of profit for dairy farmers and to optimize the availability of corn grain for human food and monogastric animal feed.

The cell wall degradability of the stems can be better predicted by its chemical composition than that of the leaves. The reasons why the cell wall degradation of leaves was not closely related with its chemical composition needs further investigation.

Within a stem, the upper internode is younger and has greater degradability than the lower internodes. The ratio between syringyl and guaiacyl compounds (S:G) (i.e., lignin composition) is more related with the cell wall degradation of the stems than the lignin content. However, more comprehensive research on the factors that limit the cell wall degradation of corn stems in the rumen is needed. In the current study, only two corn cultivars were investigated, and whether $\mathrm{S}: \mathrm{G}$ is still more predictive for cell wall degradation than the ADL content among different corn cultivars needs to be determined.

Although the lower part of a corn stem is the least degradable, its degradability cannot be improved by a fungal treatment with $L$. edodes and P. eryngii. It may be worth to use fungi to treat corn stover or stems with a greater lignin content. Furthermore, it is recommended to evaluate synergetic effects of fungal species on improvement of cell wall degradability of corn stover, and upon using less common fungal species to 


\section{CHAPTER 6}

evaluate whether these species produce toxic components to the animals or have adverse effects on the animal products for human consumption.

When the degradability of corn stover can be increased by fungal treatment, animal feeding trials should be conducted including evaluation of DMI, production performance and rumen health of dairy cows fed with the fungal treated corn stover at different milk production levels and different NDF levels in the ration.

The optimal WPCS:CSS for dairy farms to maximize their profit increased with decreasing milk production levels. At a fixed total amount of milk produced, more corn will be available for other purposes including human consumption, with high producing cows. Compared with low producing cows, the high producing cows are more efficient in nitrogen utilization to produce milk protein, and high producing cows have less enteric methane production per kg milk. In the current model, however, the influence of changes in diet composition on rumen $\mathrm{pH}$ was not considered. When the fungal treated corn stover, which has greater NDF degradability than the untreated corn stover, is fed to dairy cows, these cows may be more vulnerable to suffer from SARA. The influence of fungal treatment on the incidence of SARA and the negative effects of SARA on the profit of dairy farms should be considered.

\subsection{References}

Ammar, H., Lopez, S., Bochi-Brum, O., Garcia, R., Ranilla, M.J., 1999. Composition and in vitro digestibility of leaves and stems of grasses and legumes harvested from permanent mountain meadows at different stages of maturity. J. Anim. Feed Sci. 8, 599610.

Arora, D.S., Sharma, R.K., 2009. Enhancement in in vitro digestibility of wheat straw obtained from different geographical regions during solid state fermentation by white rot fungi. BioResources, 4, 909-920.

Boon, E.J.M.C., Engels, F., Struik, P.C., Cone, J.W., 2005. Stem characteristics of two forage maize (Zea mays L.) cultivars varying in whole plant digestibility. II. Relation between in vitro rumen fermentation characteristics and anatomical and chemical features within a single internode. NJAS-Wageningen J. Life Sci. 53, 87-109. 
Collins, M., 1988. Composition and fibre digestion in morphological components of an alfalfa-timothy sward. Anim. Feed Sci. Technol. 19, 135-143.

Combs, D.K., 2013. TTNDFD: A new approach to evaluate forages. Pages 113-125 in Proc. 2013 Cornell Nutrition Conf. Dept. Anim. Sci., Cornell Univ., Ithaca, NY.

Cone, J.W., Van Gelder, A.H., Visscher, G.J.W., Oudshoorn, L., 1996. Use of a new automated time related gas production apparatus to study the influence of substrate concentration and source of rumen fluid on fermentation kinetics. Anim. Feed Sci. Technol. 61, 113-128.

Cone, J.W., Van Gelder, A.H., Driehuis, F., 1997. Description of gas production profiles with a three-phasic model. Anim. Feed Sci. Technol. 66, 31-45.

Cone, J.W., Van Gelder, A.H., Valk, H., 1998. Prediction of nylon bag degradation characteristics of grass samples with the gas production technique. J. Sci. Food Agric. $77,421-426$.

Dei, H.K., 2011. Soybean as a feed ingredient for livestock and poultry. In: Krezhova, D. (Ed.), Recent trends for enhancing the diversity and quality of soybean products. InTech Open Access Publ., Rijeka, Croatia, pp. 215-226.

Der Bedrosian, M.C., Nestor, Jr. K., Kung, Jr. L., 2012. The effects of hybrid, maturity, and length of storage on the composition and nutritive value of corn silage. J. Dairy Sci. $95,5115-5126$.

FAO (Food and Agriculture Organization of the United Unions). FAOSTAT. 2017.

Garrett, E.F., Pereira, M.N., Nordlund, K.V., Armentano, L.E., Goodger, W.J., Oetzel, G.R., 1999. Diagnostic methods for the detection of subacute acidosis in dairy cows. J. Dairy Sci. 82, 1170-1178.

Gilliland, T.J., 1997. Changes induced by defoliation in the yield and digestivility of leaves and stems of perennial ryegrass (Lolium perenne) during reproductive development. Eur. J. Agron. 6, 257-264.

Goering, H.K., Van Soest, P.J., 1970. Forage Fiber Analyses. (Apparatus, reagents, procedures, and some application). Agric. Handbook No. 379. ARS-USDA, Washington, DC. 


\section{CHAPTER 6}

Gozho, G.N., Plaizier, J.C., Krause, D.O., Kennedy, A.D., Wittenberg, W.M., 2005. Subacute ruminal acidosis induced ruminal lipopolysaccharide release and triggers an inflammatory response. J. Dairy Sci. 88, 1399-1403.

Harika, A.S., Sharma, D.D., 1994. Quality and yield differences in maize stover due to varieties and stage of harvesting. In: Joshi, A.L., Doyle, P.T., Oosting, S.J. (Eds.), Variation in quantity and quality of fibrous crop residues. ICAR, New Delhi and Wageningen Agricultural University, Wageningen, the Netherlands, pp. 20-28.

He, Y., Dijkstra, J., Sonnenberg, A.S.M., Mouthier, T.M.B., Kabel, M.A., Hendriks, W.H., Cone, J.W., 2019. The nutritional value of the lower maize stem cannot be improved by ensiling nor by a fungal treatment. Anim. Feed Sci. Technol. 247, 92-102. Henneberg, W., Stohmann, F., 1859. Über das Erhaltungsfutter volljährigen Rindviehs. J. Landwirtsch. 3, 485-551.

Herrmann, C., Heiermann, M., Idler, C., 2011. Effects of ensiling, silage additives and storage period on methane formation of biogas crops. Bioresour. Technol. 102, 5153 5161.

Huhtanen, P., Ahvenjarvi, S., Weisbjerg, M.R., Norgaard, P., 2006. Digestion and passage of fiber in ruminants. In: Sejrsen, K., Hvelplund, T., Nielsen, M.O. (Eds.), Ruminant Physiology. Wageningen Acad. Publ., Wageningen, the Netherlands, pp. 87135.

Huhtanen, P., Asikainen, U., Arkkila, M., Jaakkola, S., 2007. Cell wall digestion and passage kinetics estimated by marker and in situ methods or by rumen evacuations in cattle fed hay 2 or 18 times daily. Anim. Feed Sci. Technol. 133, 206-227.

Huhtanen, P., Nousiainen, J., Rinne, M., 2005. Prediction of silage composition and organic matter digestibility from herbage composition and pepsin-cellulase solubility. Agric. Food Sci. 14, 154-165.

Jafari, M.A., Nikkhah, A., Sadeghi, A.A., Chamani, M., 2007. The effect of Pleurotus spp. fungi on chemical composition and in vitro digestibility of rice straw. Pak. J. Biol. Sci.15, 2460-2464.

Jancik, F., Rinne, M., Homolka, P., Cermak, B., Huntanen, P., 2011. Comparison of methods for forage digestibility determination. Anim. Feed Sci. Technol. 169, 11-23. 
Jensen, C., Weisbjerg, M.R., Norgaard, P., Hvelplund, T., 2005. Effect of maize silage maturity on site of starch and NDF digestion in lactating dairy cows. Anim. Feed Sci. Technol. 118, 279-294.

Karunanandaa, K., Varga, G.A., Akin, D.E., Rigsby, L.L., Royse, D.J., 1995. Botanical fractions of rice straw colonized by white-rot fungi: changes in chemical composition and structure. Anim. Feed Sci. Technol. 55, 179-199.

Kendall, C., Leonardi, C., Hoffman, P.C., Combs, D.K., 2009. Intake and milk production of cows fed diets that differed in dietary neutral detergent fiber and neutral detergent fiber digestibility. J. Dairy Sci. 92, 313-323.

Khan, N.A., Hussain, S., Ahmad, N., Alam, S., Bezabhi, M., Hendriks, W.H., Yu, P., Cone, J.W., 2015. Improving the feeding value of straws with Pleurotus ostreatus. Anim. Prod. Sci. 55, 241-245.

Kleen, J.L., Hooijer, G.A., Rehage, J., Noordhuizen, J.P.T.M., 2003. Subacute ruminal acidosis (SARA): a review. J. Vet. Med. A Physiol. Pathol. Clin. Med. 50, 406-414.

Krause, K.M., Otzel, G.R., 2006. Understanding and preventing subacute ruminal acidosis in dairy herds: a review. Anim. Feed Sci. Technol. 126, 215-236.

Kristensen, N.B., Sloth, K.H., Hojberg, O., Spliid, N.H., Jensen, C., Thogersen, R., 2010. Effects of microbial inoculants on corn silage fermentation, microbial contents, aerobic stability, and milk production under field conditions. J. Dairy Sci. 93, 37643774 .

Lentz, E.M., Buxton, D.R., 1992. Digestion kinetics of orchardgrass as influenced by leaf morphology, fineness of grind, and maturity group. Crop Sci. 32, 482-486.

Li, S., Yao, K., Cao, Z., Liu, C., Zhang, S., Liu, J., Li, J., Wang, J., Zhang, H., 2018. Dairy Industry and Technical Development Report in 2017. Chinese J. Anim. Sci. 3, 132-137. (In Chinese).

Liu X., Li, S., 2017. China dairy trade development. p. 54-69. In S. Li, ed. China dairy white paper (2016). Sino-Dutch Dairy Development Centre, Beijing, China.

Lynch, J.P., O’Kiely, P., Murphy, R., Doyle, E.M., 2014. Changes in chemical composition and digestibility of three maize stover components digested by white-rot fungi. J. Anim. Physiol. Anim. Nutr. 98, 731-738. 


\section{CHAPTER 6}

Ma, K., Ruan, Z., 2015. Production of a lignocellulolytic enzyme system for simultaneous bio-delignification and saccharification of corn stover employing coculture of fungi. Bioresour. Technol. 175, 586-593.

Mao, L., Sonnenberg, A.S.M., Hendriks, W.H., Cone, J.W., 2018. Preservation of Ceriporiopsis subvermispora and Lentinula edodes treated wheat straw under anaerobic conditions. J. Sci. Food Agric. 98, 1232-1239.

Mattila, P., Konko, K., Eurola, M., Pihlava, J., Astola, J., Vahteristo, L., Hietaniemi, V., Kumpulainen, J., Valtonen, M., Piironen, V., 2001. Contents of vitamins, mineral elements, and some phenolic compounds in cultivated mushrooms. J. Agric. Food Chem. 49, 2343-2348.

McCann, J.C., Luan, S., Cardoso, F.C., Derakhshani, H., Khafipour, E., Loor, J.J., 2016. Induction of subacute ruminal acidosis affects the ruminal microbiome and epithelium. Front. Microbiol. 7, 701.

Mertens, D.R., 1993. Rate and extent of digestion. In: Forbes, J.M., France, J. (Eds.), Quantitative Aspects of Ruminant Digestion and Metabolism. CAB International, Wallingford, pp. 13-50.

Mertens, D.R., 1994. Regulation of forage intake. In: Fahey, G.C., Collins, Jr. M., Mertens, D.R., Moser, L.E. (Eds.), Forage Quality, Evaluation, and Utilization. American Society of Agronomy, Crop Science Society of America, and Soil Science of America, Madison, pp. 450-493.

Meyer, J.H.F., Mackie, R.I., 1986. Microbial evaluation of the intraruminal in sacculus digestion technique. Appl. Environ. Microbiol. 51, 622-629.

Moir, R.J., 1961. A note on the relationship between the digestible dry matter and the digestible energy content of ruminant diets. Aust. J. Exp. Agric. 1, 24-26.

Morrison, I.M., 1980. Changes in the lignin and hemicellulose concentrations of ten varieties of temperate grasses with increasing maturity. Grass Forage Sci. 35, 287-293.

Morrison, T.A., Buxton, D.R., 1993. Activity of phenylalanine ammonia-lyase, tyrosine ammonia-lyase, and cinnamyl alcohol dehydrogenase in the maize stalk. Crop Sci. 33, 1264-1268.

Nayan, N., 2018a. Discerning the variation on fungal-treated wheat straw as ruminant 
feed. PhD Dissertation. Wageningen University.

Nayan, N., Sonnenberg, A.S.M., Hendriks, W.H., Cone, J.W., 2017. Differences between two strains of Ceriporiopsis subvermispora on improving the nutritive value of wheat straw for ruminants. J. Appl. Microbiol. 123, 352-361.

Nayan, N., Sonnenberg, A.S.M., Hendriks, W.H., Cone, J.W., 2018b. Variation in the solubilization of crude protein in wheat straw by different white-rot fungi. Anim. Feed Sci. Technol. 242, 135-143.

Nayan, N., Sonnenberg, A.S.M., Hendriks, W.H., Cone, J.W., 2018c. Screening of white-rot fungi for bioprocessing of wheat straw into ruminant feed. J. Appl. Microbiol. $125,468-479$.

Niu, D., Zuo, S., Jiang, D., Tian, P., Zheng, M., Xu, C., 2018. Treatment using white rot fungi changed the chemical composition of wheat straw and enhanced digestion by rumen microbiota in vitro. Anim. Feed Sci. Technol. 237, 46-54.

Noziere, P., Michalet-Doreau, B., 2000. In sacco methods. In: D’Mello J.P.F. (Ed.), Farm Animal Metabolism and Nutrition. CABI Publishing, Oxon, UK, pp. 233-253.

NRC, 2001. Nutrient Requirement of Dairy Cattle. 7th revised edition. National Academy Press, Washington D.C.

Oba, M., Allen, M.S., 1999a. Effects of brown midrib 3 mutation in corn silage on dry matter intake and productivity of high yielding dairy cows. J. Dairy Sci. 82, 135-142.

Oba, M., Allen, M.S., 1999b. Evaluation of the importance of the digestibility of neutral detergent fiber from forage: effects on dry matter intake and milk yield of dairy cows. J. Dairy Sci. 82, 589-596.

Oetzel, G.R., 2003. Subacute ruminal acidosis in dairy cattle. Adv. Dairy Technol. 15, 307-317.

Okano, K., Iida, Y., Samsuri, M., Prasetya, B., Usagawa, T., Watanabe, T., 2006. Comparison of in vitro digestibility and chemical composition among sugarcane bagasses treated by four white-rot fungi. Anim. Sci. J. 77, 308-313.

Okano, K., Ohkoshi, N., Nishiyama, A., Usagawa, T., Kitagawa, M., 2009. Improving the nutritive value of madake bamboo, Phyllostachys bambusoides, for ruminants by 


\section{CHAPTER 6}

culturing with the white-rot fungus Ceriporiopsis subvermispora. Anim. Feed Sci. Technol. 152, 278-285.

Plaizier, J.C., 2004. Alfalfa as chopped hay or silage in alfalfa based total mixed rations for lactating dairy cows. J. Dairy Sci. 87, 2495-2505.

Plaizier, J.C., Krause, D.O., Gozho, G.N., McBride, B.W., 2008. Subacute ruminal acidosis in dairy cows: The physiological causes, incidence and consequences. Vet. J. 176, 21-31.

Robinson, P.J., Fadel, J.G., Tamminga, S., 1986. Evaluation of mathematical models to describe neutral detergent residue in terms of its susceptibility to degradation in the rumen. Anim. Feed Sci. Technol. 15, 249-271.

Saha, B.C., Qureshi, N., Kennedy, G.J., Cotta, M.A., 2016. Biological pretreatment of corn stover with white-rot fungus for improved enzymatic hydrolysis. Int. Biodeterior. Biodegradation. 109, 29-35.

Sanderson, M.A., 1993. Aerobic stability and in vitro fiber digestibility of microbially inoculated corn and sorghum silage. J. Anim. Sci. 71, 505-514.

Sonnenberg, A.S.M., Visser, M.H.M., Lavrijssen, B., Cone, J.W., Hendrickx, P.M., 2016. Evaluation of king oyster mushrooms strains (Pleurotus eryngii) on selective lignin degradation in wheat straw: An update. PPO/PRI Report 2016-4, Wageningen University \& research, Wageningen, the Netherlands.

Stone, W.C., 2004. Nutritional approaches to minimize subacute ruminal acidosis and laminitis in dairy cattle. J. Dairy Sci. 87 (E. Suppl.), E13-E26.

Sun, F., Li, J., Yuan, Y., Yan, Z., Liu, X., 2011. Effect of biological pretreatment with Trametes hirsute yj9 on enzymatic hydrolysis of corn stover. Int. Biodeterior. Biodegradation 65, 931-938.

Taylor, C.C., Allen, M.S., 2005. Corn grain endosperm type and brown midrib 3 corn silage: site of digestion and ruminal digestion kinetics in lactating cows. J. Dairy Sci. $88,1413-1424$.

Tilley, J.M.A., Terry, R.A., 1963. A two-stage technique for the digestion of forage crops. J. Br. Grassl. Soc. 18, 104-111. 
Tuyen, D.V., Cone, J.W., Baars, J.J.P., Sonnenberg, A.S.M., Hendriks, W.H., 2012. Fungal strain and incubation period affect chemical composition and nutrient availability of wheat straw for rumen fermentation. Bioresour. Technol. 111, 336-342. Tuyen, D.V., Phuong, H.N., Cone, J.W., Baars, J.J.P., Sonnenberg, A.S.M., Hendriks, W.H., 2013. Effect of fungal treatments of fibrous agricultural by-products on chemical composition and in vitro rumen fermentation and methane production. Bioresour. Technol. 128, 256-263.

Van Kuijk, S.J.A., Sonnenberg, A.S.M., Baars, J.J.P., Hendriks, W.H., Cone, J.W., 2015a. Fungal treatment of lignocellulosic biomass: Importance of fungal species, colonization and time on chemical composition and in vitro rumen degradability. Anim. Feed Sci. Technol. 209, 40-50.

Van Kuijk, S.J.A., Sonnenberg, A.S.M., Baars, J.J.P., Hendriks, W.H., Cone, J.W., 2015b. Fungal treated lignocellulosic biomass as ruminant feed ingredient: a review. Biotechnol. Adv. 33, 191-202.

Van Kuijk, S.J.A., 2016a. Fungal treatment of lignocellulosic biomass. $\mathrm{PhD}$ Dissertation. Wageningen University, the Netherlands.

Van Kuijk, S.J.A., Del Rio, J.C., Rencoret, J., Gutierrez, A., Sonnenberg, A.S.M., Baars, J.J.P., Hendriks, W.H., Cone, J.W., 2016b. Selective ligninolysis of wheat straw and wood chips by the white-rot fungus Lentinula edodes and its influence on in vitro rumen degradability. J. Anim. Sci. Biotechnol. 7, 55-68.

Van Kuijk, S.J.A., Sonnenberg, A.S.M., Baars, J.J.P., Hendriks, W.H., Del Rio, J.C., Rencoret, J., Gutierrez, A., De Ruijter, N.C.A., Cone, J.W., 2017. Chemical changes and increased degradability of wheat straw and oak wood chips treated with the white rot fungi Ceriporiopsis subvermispora and Lentinula edodes. Biomass Bioenergy. 105, 381-391.

Van Soest, P.J., 1963a. Use of detergents in the analysis of fibrous feeds. I. Preparation of fiber residues of low nitrogen content. J. Assoc. Off. Agric. Chem. 46, 825-829.

Van Soest, P.J., 1963b. Use of detergents in the analysis of fibrous feeds. II. Preparation of fiber residues of low nitrogen content. J. Assoc. Off. Agric. Chem. 46, 829-835.

Verbic, J., Stekar, J.M.A., Resnik-Cepon, M., 1995. Rumen degradation characteristics 


\section{CHAPTER 6}

and fibre composition of various morphological parts of different maize hybrids and possible consequences for breeding. Anim. Feed Sci. Technol. 54, 133-148.

Wan, C., Li, Y., 2010. Microbial delignification of corn stover by Ceriporiopsis subvermispora for improving cellulose digestibility. Enzyme Microb. Technol. 47, 3136.

Westwood, C.T., Bramley, E., Lean, I.J., 2003. Review of the relationship between nutrition and lameness in pasture-fed dairy cattle. N. Z. Vet. J. 51, 208-218.

Xu, C., Ma, F., Zhang, X., Chen, S., 2010. Biological pretreatment of corn stover by Irpex lacteus for enzymatic hydrolysis. J. Agric. Food Chem. 58, 10893-10898.

Yan, J., Wang, W., Gao, Y., Mu, S., 2009a. Variation law of corn straw silage nutritional quality in different storage periods. Acta. Agric. Boreali-occidentalis Sinica. 18, 57-60. (In Chinese).

Yan, J., Wang, W., Gao, Y., Mu, S., 2009b. Variation law of whole-plant corn silage nutritional quality under different storage periods. J. Northwest A. F. Univ. (Nat. Sci. Ed.). 37, 75-80. (In Chinese).

Zebeli, Q., Aschenbach, J.R., Tafaj, M., Boguhn, J., Ametaj, B.N., Drochner, W., 2012. Invited review: Role of physically effective fiber and estimation of dietary fiber adequacy in high-producing dairy cattle. J. Dairy Sci. 95, 1041-1056. 
Summary 


\section{SUMMARY}

Corn stover is one of the most abundant crop residues in China. About $70 \%$ of the stover is burned on the field or used as household fuel, which may cause environmental pollution. Only $10 \%$ is used as ruminant feed, due to its low degradability. Utilization of corn stover as ruminant feed may not only decrease the environmental pollution, caused by burning, but also improve the profit of dairy farms, since the price of corn stover is always low. Besides, inclusion of corn stover in the ration for dairy cows may save more corn grain for human consumption or animal feed.

The least degradable part of corn stover (leaves and stems) was identified first (Chapter 2 and 3). The chemical composition and in vitro gas production (IVGP) parameters of corn leaves and stems were investigated separately. Also the relationship between the IVGP parameters with the chemical composition of thirteen corn cultivars was studied (Chapter 2). For most investigated cultivars, the cumulative gas production between 3 and $20 \mathrm{~h}$ (A2) of the leaves, representing cell wall degradability, and the half-time value (B2) of leaves, representing rate of cell wall degradation, was greater than that of the stems. Both A2 and the cumulative $72 \mathrm{~h}$ gas production (GP72) of the stems were highly correlated with its chemical composition. For the leaves, A2 and GP72 only showed moderate relationships with the chemical composition. The cell wall degradation of different internodes from the stem and of internodes harvested during the growing season was studied (Chapter 3) to find the least degradable part of the stem and to evaluate which factor (lignin content and composition) is most decisive for the cell wall degradation of corn stems. The ADL content and the S:G ratio increased from the upper internodes to the lower internodes within the stem for two selected corn cultivars and the ratio between syringyl and guaiacyl alcohol ( $\mathrm{S}: \mathrm{G}$ ratio) in internode 7 tended to increase during the growing season. However, the ADL content in internode 7 fluctuated during maturation. Cell wall degradability, as indicated by A2, tended to decrease up to August 14 with no clear pattern after August 14, whereas cell wall degradability increased with internode number. For corn stems, the S:G ratio showed a better relationship with cell wall degradability than the ADL content. A lower S:G ratio was accompanied by a higher degradability.

Since the lower part of corn stems is less degradable than the upper part, the lower part was chosen to explore whether a fungal treatment or ensiling can enhance the cell wall degradation (Chapter 4). Both ensiling and fungal treatment by Lentinula edodes and Pleurotus eryngii did not improve the degradation of the lower part of the stem of the 
two corn cultivars. During the ensiling and the fungal treatment, the change in chemical composition was mainly derived from the utilization of water soluble carbohydrates by microorganisms and the degradation of hemicellulose by the fungi, respectively.

The proper ratio of corn plants used as whole plant corn silage and corn stover silage, to maximize the profit of dairy farmers, was determined by using an optimization model (Chapter 5). The optimal WPCS:CSS ratio for dairy farms to maximize their profit increases with decreased milk production levels. However, at a fixed total amount of milk being produced, more corn will be available for other purposes including human consumption, with high producing cows fed a diet with an optimal WPCS:CSS ratio. At the optimal WPCS:CSS ratio for each milk production level, methane emission intensity is smaller, and milk nitrogen $(\mathrm{N})$ efficiency is greater, with high producing cows compared with low producing cows, which may alleviate the environment pollution related to dairy production.

The studies presented in this thesis describe the value of corn stover for Chinese dairy farms. Although the lower part of corn stover was identified as the least degradable part of the stover, its degradability did not increase by a fungal treatment with L. edodes and P. eryngii for 9 weeks. Another major finding in this thesis is that high producing cows can save more corn grain for other purposes, and showed a smaller methane emission intensity and greater milk $\mathrm{N}$ efficiency. Future studies can focus on identifying the factors to determine the degradability of corn stover, breeding the corn for a greater cell wall degradability and optimizing corn stover in the ration of dairy cows. 
Acknowledgements 


\section{ACKNOWLEDGEMENTS}

When I am writing the Acknowledgements, I realize that my $\mathrm{PhD}$ studies at Wageningen University are almost finished. I would like to take the opportunity to express my appreciation to supervisors, colleagues and friends.

First of all, I would like to thank the Sino-Dutch Dairy Development Center (SDDDC) for providing me the chance to study at Wageningen University and for their financial support during my study.

This thesis would not have been finished without the supervision from my promotors and co-promotor. For me, utilization of corn stover for ruminant animals was an "old" research topic. But, Wouter, an excellent promotor, enlightened me a lot in this project and helped me to go through the tough times. Jan, I have to say that you are the reason that I choose to apply for the project of SDDDC. If you didn't agree to be my supervisor four years ago, I would definitely have quit. Thank you for your guidance and dedication to the project. John, thank you for giving me excellent suggestions and great help during my study.

I would also like to thank my supervisors and friends in China, who helped me during my study. Professor Shengli Li, thank you for helping me to apply for this $\mathrm{PhD}$ project. Dr. Zhijun Cao, a supervisor and a friend to me, thank you for your advice about finding jobs and inviting me to visit the farms and companies in the dairy industry in Israel, which broadened my view considerably. Thanks are due to the managers of SDDDC, Kai and Xiao, for providing me the data pertaining to the Chinese dairy industry. Dr. Yajing Wang, thank you for your encouragement during my study. Jiaying, Hongkai, Shuai and Naren, thank you for helping me to download the references in Chinese.

My special thanks go to the secretaries of the Animal Nutrition group, Yvonne and Betty, for providing me endless help when I met troubles in my project and administrative issues. 
Many thanks to my colleagues, Mirjam and Thibaut, for helping me to perform pyrolysis and analyze the data for me. Anton and Marcel really helped me a lot during the fungal trial. Lei, Mandy, Eli, Jing and Taolin have been so nice and patient to help me to separate corn plants well into the evening. I also would like to acknowledge the laboratory technicians: Jane-Martine, Xuan Huong, Saskia, Erika, Leon and Michel. Thanks for your help in the lab works. I want to express my appreciation to my $\mathrm{PhD}$ colleagues for the group activities and cakes, and wish you all the best in your future.

To my Chinese friends, I am glad to meet you all. 春月，我们是一起申请的 SDDDC 的项目，坐一趟飞机来的荷兰，答辩时间只相差一个星期，刚来荷兰的时候几 乎天天在你家蹭饭, 有很多感谢的话, 下次去蹭饭的时候再对你和真爱说吧。 吕芳, 非常感谢你无微不至的照顾。旭哥, 材哥, 唐师兄, 张扬, 一直记得我 们经常玩三国杀到凌晨, 如果没有你们, 标哥也许去年就能毕业了。自从标哥 成为动科一哥之后, 经常叫我打麻将, 其实我心里是拒绝的, 只是身体很诚实。 感谢牟文娟师姐和郭学珍师兄, 每次和师兄聊天都很有趣, 师姐在学习上给了 很多建议, 最令我难忘的是师姐总是找机会给别人介绍对象, 这种铸而不舍的 精神一直激励着我, 千万不能单身。感谢张圣师兄和孟金师姐, 很开心能够一 起吃饭, 一起健身。还要感谢包曼师姐、小包、海博、岳岳、梦婷、邓亚乐、 徐蔚、胡义信, 还有好多朋友, 就不再一一列举了。

My special thanks to Kobe, my favorite basketball player. Your Mamba Mentality always inspires me. Be passionate and obsessive to the things that I want to do. And I will.

感谢父母对我的培养和支持, 在我选择来荷兰读博士的时候, 你们并没有阻拦, 给了我很多鼓励, 很内疚不能在你们身边照顾你们, 我爱你们。 


\title{
About the author
}

\author{
Curriculum vitae
}

List of publications

Training and supervision plan 


\section{About the author \\ Curriculum Vitae}

Yuan He was born on 16 August 1990 in Xinyang, China. He started his bachelor study in Animal Sciences at the China Agricultural University in 2008. His BSc thesis was supervised by Prof. Xiaoming Zhang within a program on calcium salt fatty acids in dairy cattle nutrition. After his BSc study, he performed his MSc study under the supervision of Prof. Shengli Li. During his MSc study, he became a member of Elite Cattlemen Program, which made him experienced in practical work at the dairy farm, gaining more knowledge of the dairy industry and broadening his view. He began his $\mathrm{PhD}$ in 2014 at Animal Nutrition Group of Wageningen University \& Research, which is supported by Sino-Dutch Dairy Dvelopment Centre aiming to solve the problems in local dairy farming system. 


\section{List of publications}

1. He, Y., Mouthier, T.M.B., Kabel, M.A., Dijkstra, J., Hendriks, W.H., Struik, P.C., Cone, J.W., 2018. Lignin compositions is more important than content for maize stem cell wall degradation. J. Sci. Food Agric. 98, 383-390.

2. He, Y., Dijkstra, J., Sonnenberg, A.S.M., Mouthier, T.M.B., Kabel, M.A., Hendriks, W.H., Cone, J.W., 2019. The nutritional value of the lower maize stem cannot be improved by ensiling nor by a fungal treatment. Anim. Feed Sci. Technol. 247, 92-102.

3. He, Y., Cone, J.W., Hendriks, W.H., Dijkstra, J. Relationships between chemical composition and in vitro gas production parameters of maize leaves and stems. Submitted to J. Anim. Physiol. Anim. Nutr.

4. He, Y., Cone, J.W., Hendriks, W.H., Dijkstra, J. Corn stover usage and farm profit for sustainable dairy farming in China. Submitted to Asian Australas. J. Anim. Sci. 


\section{About the author \\ Train and Supervision Plan}

\section{The Basic Package (2 ECTS)}

WIAS Introduction Day (2015)

Ethics and Philosophy in Life Sciences (2015)

\section{Disciplinary Competences (18 ECTS)}

Writing research proposals (2015)

Design of Experiments (2015)

Statistics for the Life Sciences (2015)

ANU-30306 Nutrient Dynamics (2015)

Orientation on Mathematical Modelling in Biology (2016)

Nutriscience: Global Nutrition from Nutrients to Whole diets (2017)

\section{Professional Competences (8 ECTS)}

Techniques for Writing and Presenting a Scientific Paper (2015)

Project and Time Management (2015)

Information Literacy Including Endnote Introduction (2015)

Systematic Approaches to Reviewing Literature (2016)

Brain Training (2016)

\section{Presentation Skills (3 ECTS)}

Animal Nutrition Forum, Belgium; Oral (2015)

Animal Nutrition Forum, Belgium; Oral (2017) 
About the author

ADSA, Pittsburgh, USA; poster (2017)

\section{Total 31 ECTS}




\section{Colophon}

The project was funded by the Sino-Dutch Dairy Development Centre and Wageningen University \& Research.

Cover design and layout by Yuan He

Thesis layout and printed by Proefschriftmaken || Digiforce 


\section{Propositions}

1. A high lignin content of biomass is not a guarantee for successful fungal treatment to increase its the degradability. (this thesis)

2. In terms of sustainability, dairy cows can consume more human inedible ingredients but this increase com es with a lesser $m$ ilk nitrogen efficiency and greater methane emission intensity.

(this thesis)

3. The recent birth of the first genom e-edited infant clearly shows that not only the researchers should pay attention to the ethics in scientific research but also the general public.

4. One strategy to think about new ideas in research is permutation and combination of previous studies.

5. Enthusiasm is a catalyst for innovation.

6. Studying towards a $\mathrm{PhD}$ degree in dairy cattle nutrition does not mean one is experienced in practical work on dairy farms.

Propositions belonging to the thesis, entitled

The value of corn stover for Chinese dairy farms

Yuan $\mathrm{He}$

Wageningen, 1 May 2019 